\title{
Fathers, pastors and kings
}

\section{Visions of episcopacy in seventeenth-century France}

\section{ALISON FORRESTAL}

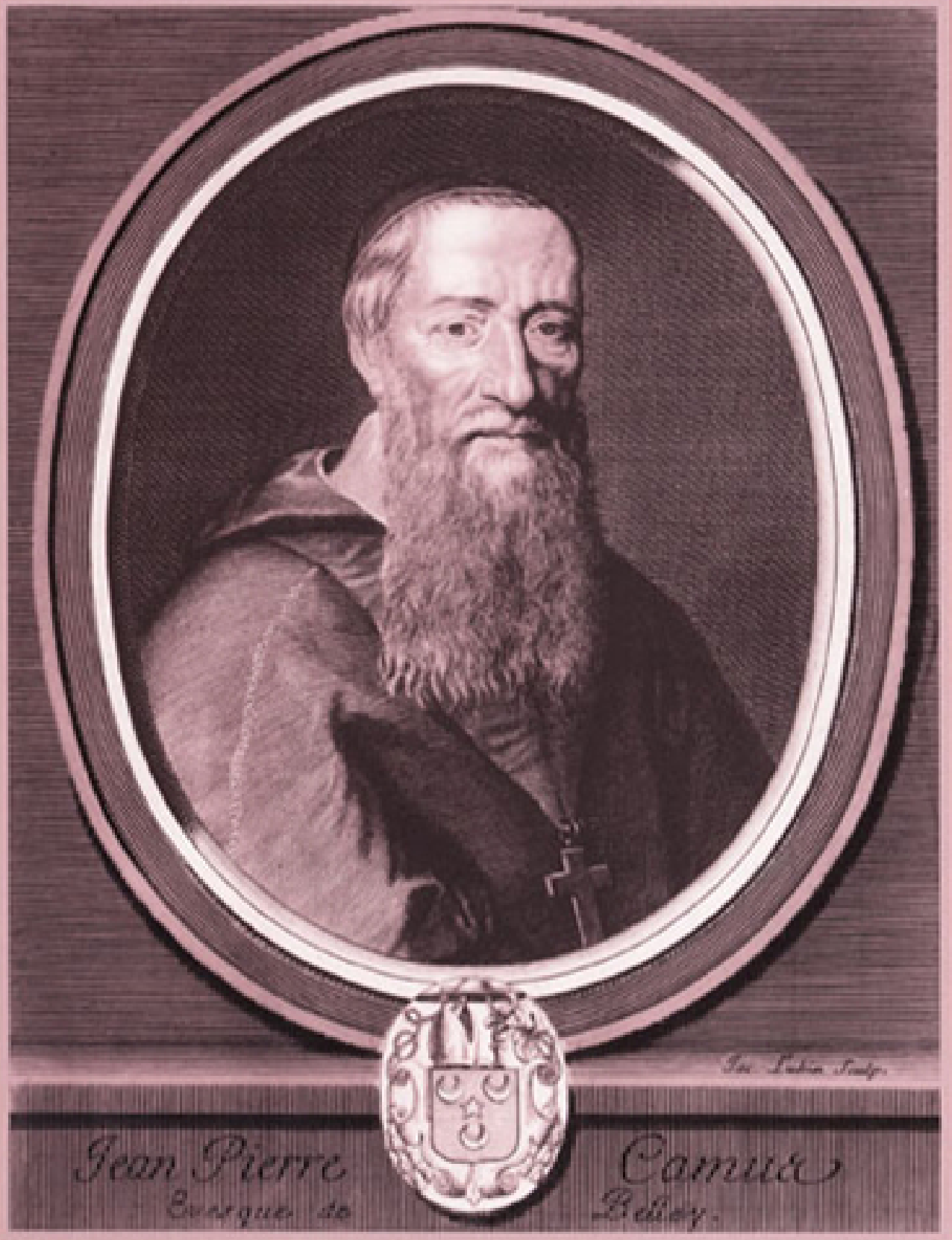




\section{Fathers, pastors and kings}

Published in our centenary year

$\approx 2004 \cong$

MANCHESTER

UN I VERS I T Y

PRESS 


\section{STUDIES IN EARLY MODERN EUROPEAN HISTORY}

This series aims to publish

challenging and innovative research in all areas of early modern continental history.

The editors are committed to encouraging work that engages with current historiographical debates, adopts an interdisciplinary approach, or makes an original contribution to our understanding of the period.

SERIES EDITORS

Joseph Bergin, William G. Naphy, Penny Roberts and Paolo Rossi

Already published in the series

The rise of Richelieu Joseph Bergin

Sodomy in early modern Europe ed. Tom Betteridge

The Malleus Maleficarum and the construction of witchcraft Hans Peter Broedel

Fear in early modern society eds William Naphy and Penny Roberts

Religion and superstitition in Reformation Europe eds Helen Parish and William G. Naphy

Religious choice in the Dutch Republic: the reformation of Arnoldus Buchelus (1565-1641) Judith Pollman

Witchcraft narratives in Germany: Rothenburg, 1561-1652 Alison Rowlands 


\title{
Fathers, pastors and kings Visions of episcopacy in seventeenth-century France
}

\author{
ALISON FORRESTAL
}

Manchester University Press

Manchester and New York 


\section{Copyright (C) Alison Forrestal 2004}

The right of Alison Forrestal to be identified as the author of this work has been asserted by her in accordance with the Copyright, Designs and Patents Act 1988.

Published by Manchester University Press

Oxford Road, Manchester M13 9NR, UK

and Room 400, 175 Fifth Avenue, New York, NY10010, USA

www.manchesteruniversitypress.co.uk

Distributed exclusively in the USA by

Palgrave, 175 Fifth Avenue, New York, NY10010, USA

Distributed exclusively in Canada by

UBC Press, University of British Columbia, 2029 West Mall,

Vancouver, BC, Canada V6T 1Z2

British Library Cataloguing-in-Publication Data

A catalogue record is available from the British Library

Library of Congress Cataloging-in-Publication Data applied for

ISBN 0719069769 hardback

First published 2004

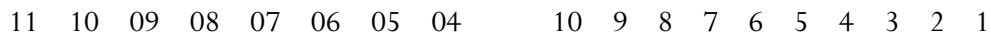

The publisher has no responsibility for the persistence or accuracy of URLs for any external or third-party internet websites referred to in this book, and does not guarantee that any content on such websites is, or will remain, accurate or appropriate.

Typeset in Monotype Perpetua with Albertus by Northern Phototypesetting Co Ltd, Bolton 


\section{For Richie}


Alison Forrestal - 9781526120625 Downloaded from manchesterhive.com at $04 / 26 / 2023$ 12:46:50PM via free access 


\section{Contents}

Acknowledgements

page viii

List of abbreviations

Map of French dioceses

Introduction

1 Catholic renewal and episcopal traditions in the sixteenth century

2 The most perfect state: French clerical reformers and episcopal status

3 Lower clergy versus bishops $\quad 74$

4 Ecclesiastical monarchy or monarchies? 109

5 An uneasy alliance 144

6 Manuals and hagiography: mirrors of French ideals? 171

$\begin{array}{ll}\text { Conclusion } & 214\end{array}$

Appendix: chronology of principal events 229

Bibliography 232

Index 254 


\section{Acknowledgements}

In recognition of their advice and support as this project progressed, I thank Joseph Bergin, Robin Briggs, Raymond Gillespie, Sheridan Gilley, Colin Jones, Peter Marshall, Rana Mitter, Henry Phillips, the staff and referees of Manchester University Press and the members of the Forrestal 'clan'.

I am also grateful for the financial support that I received from the University of Manchester and the University of Durham. Finally, I thank the editors of the Journal of Ecclesiastical History for permission to reproduce material from volume 54 (2003), 254-77, and the editor of The Seventeenth Century for permission to reproduce material from volume 17 (2002), $24-47$. 


\section{List of abbreviations}

AAE

AN

BN

JEH

Ms. Fr.

Procès-verbaux

Recueil des actes
Archives des Affaires Etrangères, Paris

Archives Nationales, Paris

Bibliothèque Nationale, Paris

Journal of Ecclesiastical History

Manuscrit français

Collection des procès-verbaux des assemblées générales du clergé de France, ed. A. Duranthon, 9 vols (Paris 1767-78)

Recueil des actes, titres et mémoires concernant les affaires du clergé de France, augmenté d'un grand nombre de pièces et d'observations sur la discipline présente de l'église, divisé en douze tomes et mis en nouvel ordre suivant la délibération de l'assemblée générale du clergé du 29 août 1705, 12 vols (Paris 1768-71) 


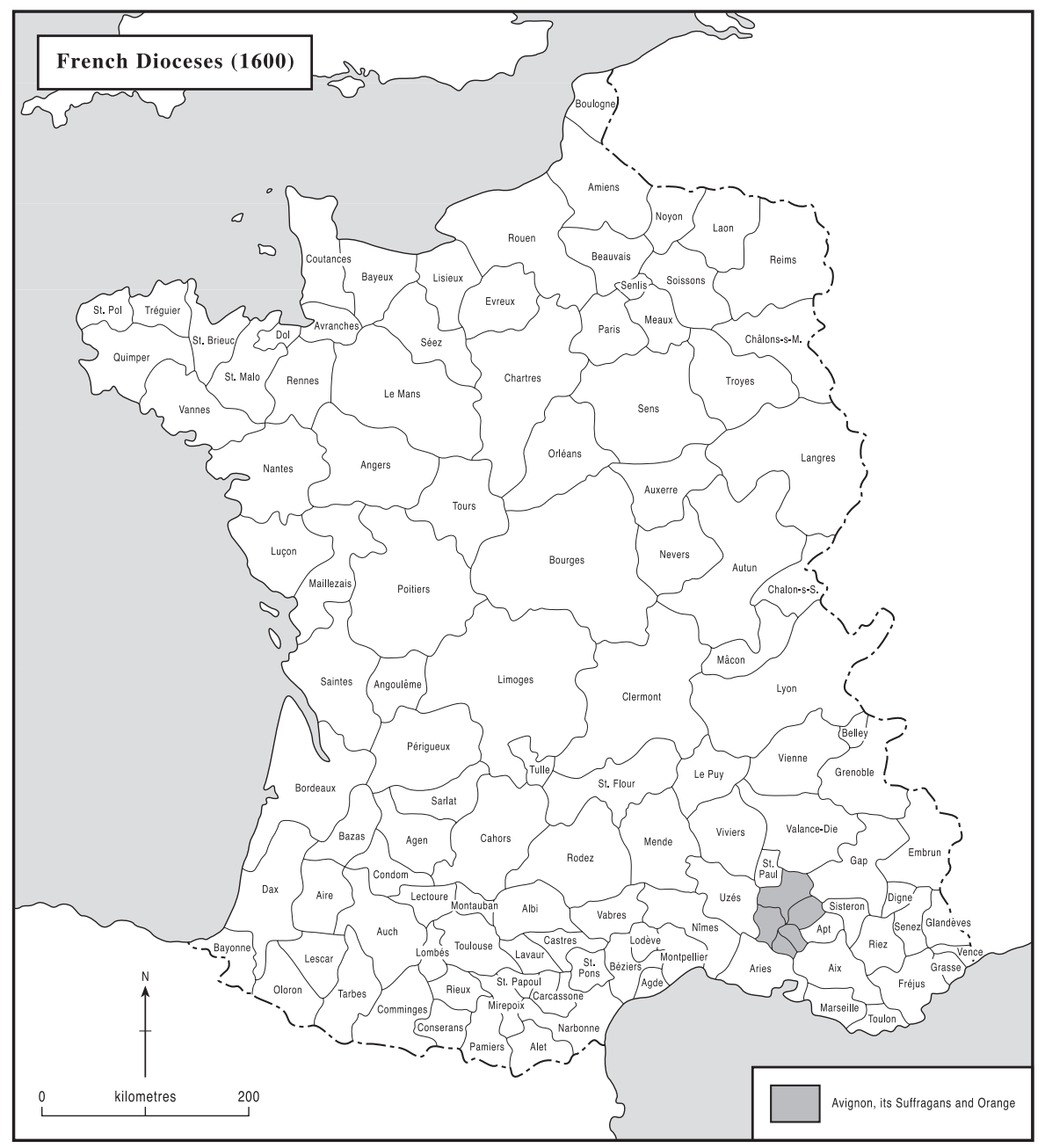

Alison Forrestal - 9781526120625 


\section{Introduction}

An overview of the Catholic episcopate in early modern Europe comments that 'one of the most far-reaching if usually under-remarked changes of the Reformation period as a whole concerns the function and necessity of bishops in the church'. 'Although immediately applicable to those regions of the Reformation where bishops disappeared altogether from the ecclesiastical and political landscapes, this observation might appear to have no relation to Catholic Europe. ${ }^{2}$ Here, bishops not only survived but also thrived, and it might seem, at first glance, that neither their function nor necessity actually changed at all through the sixteenth and seventeenth centuries. The Catholic church had consecrated bishops from its earliest times; these were the supervisors of dioceses and the leaders of the faithful, and the Council of Trent simply reinforced that role by re-issuing customary rules that ordered bishops to reside in their dioceses, hold synods and visitations, and discipline their clergy. Yet this fundamental continuity belies the immense shifts in the understanding of episcopacy that occurred through the Tridentine period, for it hides the debates and the developments in episcopal theology and practice that preoccupied bishops and other reformers. That flux was nowhere more evident than in the French church, one of the major bastions of catholicism, with an overwhelmingly Catholic population and monarchs who prided themselves on the impeccable Catholic credentials of 'most Christian king' and 'eldest son of the Church'. Amid the vigorous reform currents of this seventeenth-century realm, there arose an unprecedented debate on the nature and practice of episcopacy. It had a profound impact on the episcopate and its relationship with the Tridentine papacy and the French crown, and ultimately shaped the French church for the remainder of the ancien régime. At its heart stood its keenest participants, the body of prelates that formed the French episcopate.

Historians have long understood that to grasp the nature of early modern catholicism, one must attend to its bishops. In the traditional 'confessional' accounts of the Counter-Reformation, they assumed pivotal positions in the 
church's battle to defeat the spectre of Protestant heresy. Virtuous and diligent bishops glorified the legitimacy, morality and superiority of the Catholic cause at the expense of protestantism. Their activities were subjected to generations of scholarship that judged the success or failure of Catholic reform according to the apparent ability of successive popes and bishops to legislate, discipline and convert as the decrees of Trent required. ${ }^{3}$ Of course, their role in devising those reforms was also well documented. When Hubert Jedin produced his monumental study of the Council of Trent, he placed bishops firmly at the core of its negotiations and outcome: their role as the negotiators and formulators of the decrees ensured that the Council would become one of the pillars that would secure the triumphant success of the Counter-Reformation. ${ }^{4}$ This was also Jedin's vantage point in his famous short summary of the bishops who epitomised the Tridentine style of episcopacy that emerged in the Council's wake. Singling out just a handful of remarkable prelates like Gabriele Paleotti, Barthélemy des Martyrs and the acclaimed archbishop of Milan, Charles Borromeo, as examples of the excellent Tridentine bishop, Jedin straightforwardly characterised this model as a pastorate imbued with sane doctrine, preaching and administrative zeal and personal virtue. ${ }^{5}$ This was the episcopal spirit of the Counter-Reformation, a powerful contributor to the fervour of action and engagement with the world that Outram Evennett identified as the fundamental characteristic of Catholic reform during the early modern era. ${ }^{6}$

With some significant exceptions, however, bishops currently, though undeservedly, remain unfashionable in the historiography of early modern catholicism. Since the 1950s, the customary concentration on the institutional aspects of Catholic reform has been counterbalanced by a new emphasis on the 'religion of the people'. With the welcome broadening of horizons brought by the histoire des mentalités and socio-historical methods of research, increasing attention has been paid to the religious culture of the 'ordinary' Christians whose lives were affected, to a greater or lesser extent, by the profound shifts in belief and ritual brought about by the Protestant and Catholic Reformations. ${ }^{7}$ French historiography has been at the forefront of these developments, and scholars like Le Bras and Delumeau, as well as their many disciples, have contributed to our realisation that the religion of the masses was not absolutely superstitious, colourless or homogenous. ${ }^{8}$ Unfortunately, however, bishops tend to be marginalised in this type of scholarship. When they do enter the pages of books that investigate popular religious beliefs and practices, they are often as stereotyped as the hagiographic bishops who graced the older confessional texts: distant figures who impinge on the routine affairs of most of the faithful only when they attempt to enforce the unyielding decrees of the Council of Trent. In reality, however, bishops were not two-dimensional silhouettes. They came in all shapes and sizes and cannot be simplistically labelled good or 
bad prelates, as tended to be done in older texts, on the basis of a few stock criteria such as residence, preaching ability or alms-giving. Nor, however, should they be pushed to the sidelines in our exploration of early modern catholicism, for if the religion of ordinary men was eclectic, lively and significant, so too were the careers and experiences of their bishops.

This is nowhere more apparent than in the lives of those who made up the seventeenth-century French episcopate, one of the major elites of Bourbon France. While other social and religious groups, like the nobility and the Jansenists, have not lacked efforts to reconstruct their identities, mentalities and ideals, ${ }^{9}$ historians have rarely considered the episcopate as an identifiable caste with a variety of principles that informed its social and ecclesiastical positions, shaped its actions and profoundly influenced its church and society. Instead, its bishops have suffered from the combined effects of hagiography, caricature and neglect, even though their era itself has attracted substantial historical scholarship. What generations of scholars have, perhaps with exaggeration, called its 'religious renaissance' has proved a particularly fascinating and fruitful sphere of study, largely owing to its rich diversity of religious experience: the energetic careers of reformers like Pierre de Bérulle, Jean-Jacques Olier and Vincent de Paul; the attempts to introduce Tridentine catholicism into dioceses; the characters of and relationship between popular and elite religion; the politicoreligious conflicts of Jansenism and Quietism. Since the 1970s, one particularly helpful development within the socio-historical school has been the attempts to marry study of the 'high clergy' and the 'ordinary people' within a diocesan perspective, so that neither is viewed in isolation but rather the two are viewed in relation to each other. The type of diocesan histories undertaken by scholars as diverse as Robert Sauzet, Keith Luria and Bernard Peyrous provide a more realistic picture of religious change within France during the sixteenth and seventeenth centuries; resistance to episcopal discipline has been shown to be almost as common as acquiescence and, as both Sauzet and Luria demonstrate, the contrasting personalities and approaches of prelates often had a significant impact on the path of reform. ${ }^{10}$ Pierre Scarron of Grenoble adopted a very different approach to diocesan reform from his successor, Étienne Le Camus. Scarron turned out to be a far more inconsistent administrator and pastor, often preferring the solitude of his library to the discomforts of synods and visitations, and lacking Le Camus's enviable energy and organisational acumen. ${ }^{11}$

These recent works raise important questions of methodology and interpretation for any study of the French episcopate. Their dynamic amalgamation of popular religion with episcopal actions has placed bishops rather closer to the centre of religious life. Equally, they have helped to redress the imbalances of older texts by emphasising the variety present within experiences of episcopal action and reform, thereby accommodating nuances of episcopal personality 
and governing style into their analyses of religious life. Previously, Paul Broutin's La Réforme pastorale en France au xviie siècle, ${ }^{12}$ for several decades the standard historical study of the French episcopate, had opted for a thoroughly conventional approach to the question of reform. Neither a broad narrative of reform nor a detailed treatment of a particular aspect of religious change, this work set out to trace the path of French ecclesiastical reform in monographic style, using the categories of episcopal ministry, institutional initiatives and contemporary publications. Drawing on a variety of sources, Broutin then attempted to produce a synthesis of reform, by mapping the characteristics of key elements in that process. For the purpose of this study, his account of the lives of reforming bishops continues to be a valuable source. In general, however, Broutin's approach simply does not do justice to the experiences and values of his subjects. In the first place, Réforme pastorale is essentially a series of monographs of aspects of French reform but, beyond the broad concept of ecclesiastical change, it has no common theme or thread binding its individual sections. Secondly, and related to the disjointed nature of his account, Broutin falls prey to the tendency to label bishops arbitrarily, either as disciples of the Milanese archbishop and saint, Charles Borromeo, or as worldly politiques of the Bourbon regime. While his study is presented in the form of individual accounts of the lives of bishops, his generalisations are far too presumptive, prescriptive and clear-cut to carry conviction, and leave little room for a blurring of categories or for the possibility of multiple or even alternative influences, ideas and models of episcopacy in the French church. Finally, in his quest to present the seventeenth-century episcopate in the best possible light, Broutin's work frequently suffers from a lack of objectivity, offering an image of the episcopate that is at times as hagiographic in tone as the seventeenth-century episcopal biographies on which his scholarship is partially based. This is largely the result of Broutin's uncritical use of several of these sources to compose his own biographical sketches of individual bishops.

The weaknesses of Broutin's influential scholarship thus leave plenty of scope for further investigation of the French episcopate in terms of the development of ideas on episcopacy and the formation of models for bishops to adopt in their ministries. In fact, because more recent work on the episcopate has tended to work along lines very different from those of Broutin's study, the challenge to improve on his findings remains wide open. By tracing the experiences of individual bishops, several studies have highlighted the complexity of the episcopate as it is revealed through educational paths, administrative practices and even spirituality. ${ }^{13}$ Yet, however useful studies of individual characters may be, it is prosopographic works which draw together the particular experiences of bishops into a general analysis of the episcopate and which attempt to describe the collective evolution of these ecclesiastical figures. Certainly the broadest work in time-scale, and for several years the most detailed discussion 
of the seventeenth-century episcopate, was Michel Péronnet's thesis 'Les Evêques de l'ancienne France', ${ }^{14}$ which deals with the entire episcopate between the Concordat of Bologna and the 1789 Revolution. Péronnet examines the bishops in terms of their social origins, education and pre-episcopal careers, and concludes that the French episcopate, including 1,416 bishops, underwent a process of 'regularisation' during this period, which enabled it to assume its domination of the church and its elite position within society. His work confirms the findings made previously by Ravitch and Hayden, both of which show an episcopate monopolised by the nobility during the seventeenth century, but is far more wide-ranging thematically and in time-scale. ${ }^{15}$

None of these studies, however, deals principally with the seventeenthcentury episcopate; in fact, the only study to do so is has been The Making of the French Episcopate by Joseph Bergin. Ambitious in its thematic scope, this detailed examination of the 351 prelates installed between 1589 and 1661 presents an expansive profile of the episcopate as it developed, shattered and demoralised, from the religious wars into an assertive, confident and powerful elite in the second half of the seventeenth century. ${ }^{16}$ Bergin's work builds on the foundations laid by earlier scholars, analysing the social, educational and geographical origins of bishops, their pre-episcopal careers and crown patronage of bishoprics. He also particularly relates bishops to their sees, through analyses of patterns of tenure and of their activities in dioceses, concluding that the episcopate generally managed to maintain an equilibrium of tenure and administration that enabled it to oversee its dioceses with considerable efficiency. As Bergin's more recent article in Past and Present admits, these bishops were not unique in experiencing a revaluation of their office during the early modern era. Both the Protestant and Catholic Reformations elsewhere forced bishops to adjust their activities in answer to the criticisms of reformers on both sides. ${ }^{17}$ Undoubtedly, however, the seventeenth-century French episcopate was especially successful in responding to religious reform and political power play, in order to become a flourishing participant in the religious, political and social life of the ancien régime.

These publications have added greatly not only to the historiography of French episcopacy, but also, more broadly, to that of early modern French catholicism, because they offer new views on the development and character of a formidable clerical elite. Generally, they differ both in their methodological approaches and in their principal focuses and aims; Péronnet and Bergin have provided the most comprehensive studies of the episcopate thus far, presenting composite pictures of the influence of geography, politics, social origins and education on the episcopate. We now know that the episcopate underwent crucial changes during the seventeenth century, and that during the first six decades or so of this century it assumed the character that it would maintain throughout the remainder of the 
ancien régime. These decades were of decisive importance for the recovery of its confidence and status within church and society. No doubt this in turn was helped at one level by the fact that it was during these decades that the nobility regained and consolidated its hold over appointments, despite a rise in commoner nominations during the early years of Henri IV's reign and during the 1630s. The period also saw an increase in the number of bishops who possessed an impressive educational record, with even the sons of the nobility now attending university. Bergin estimates that 84 per cent of bishops during the period 1589-1661 held a degree of some kind, with growing numbers opting for theology rather than law. ${ }^{18}$ This was a considerable increase since 1614, when, according to Hayden, only 38 per cent did so. ${ }^{19}$ Essential as they are to our knowledge of the episcopate and French society, however, these findings actually raise new questions, about matters such as the effect of improved educational levels on the outlooks and expectations of bishops. Did growing theological literacy have an impact upon their understanding of their office? Well-educated bishops were hardly likely to be satisfied with traditional doctrines on episcopacy, several of which had never been fully developed. And if this was so, to whom did bishops look to supply new ideas that would improve upon what they considered the inadequacies of existing thought? So, despite the progress made since the 1970s, there are further significant aspects of the history of episcopacy and of early modern catholicism which have been almost completely neglected by historians.

The time is ripe for a fresh study of the episcopate, for none of the above studies has addressed a profound issue: the significance of episcopacy to those who filled its ranks. The central goals of this book are, first, to investigate the ideas, both established and still emerging, of what the office of bishop meant to its incumbents and, second, to trace the ways in which that understanding coloured their involvement in the hierarchical Tridentine church and in a temporal realm governed by a vigorously gallican monarchy. ${ }^{20} \mathrm{~A}$ series of short essays by Pierre Blet, Raymond Darricau and Réné Taveneaux have already suggested some possible conceptions of episcopacy that circulated within France, in particular among reformers and Jansenists. They highlight the traditional titles of pastor, judge and vicar that denoted functions of episcopacy, but none ventures to gauge systematically the practical impact of these images on more than a select and small band of bishops. ${ }^{21}$ In fact, these articles simply whet the historical appetite, for they concentrate almost entirely on two specific aspects of the episcopal office: administration and teaching. Yet for seventeenth-century theologians, canonists, reformers and bishops, these were not the only dimensions to the episcopate. A multilayered approach to ideals and ideology which takes account of this fact produces a far more complete understanding of the principles that guided bishops in their manifold activities. 
To achieve this, the book subdivides the office of episcopacy into its key elements, that is, into those categories which traditionally formed the basis of any dissection of the episcopal condition: the canonical and theological aspects which relate to the office as a sacred ecclesiastical position with particular associated powers, the character of the episcopal pastorate and, finally, the notion of episcopal spirituality. It traces the development of views upon each particular element of the office through discussing the various interpretations which circulated in seventeenth-century France. By drawing these individual strands together, we shall then be in a position to answer the question of whether a distinctive ideology, which provided an overall vision of episcopacy for prelates, emerged in France over the course of the century. The social and educational backgrounds of bishops tell us something of the type of bishop commonly present within what Péronnet dubbed the 'regularised' episcopate. Yet until now we have known very little about the influence of other factors such as theology, canon law and contemporary spiritual trends on ideas of episcopacy and on bishops' outlook and perception of their office. It is dangerous, though common, to generalise about the episcopate on the basis of a few judiciously chosen, and readily available, remarkable examples. It is also too easy to assume that flamboyant and notorious politique bishops like Cardinal Richelieu, Archbishop Harlay of Paris or the military archbishop of Bordeaux, Henri de Sourdis, did not possess a shred of religious commitment when it came to their episcopal vocations. Yet the reality is far more complex, for even political activities could be reconciled with the spiritual functions of the office in order to neutralise accusations of mercenary worldliness. Moreover, beside the flamboyant 'Harlays' stand less well-known bishops like Sourdis's brother, François, a diligent, devout and fiery archbishop and cardinal, whose dedication to his vocation was built on forceful ideals of religious leadership, service and honour. This study allows the idiosyncrasies of individual bishops to breathe, while simultaneously presenting those common convictions and ideals that shaped their corporal identity. Prelates like Henri and François de Sourdis, who differed wildly in their approaches to some aspects of their office, frequently found far more common episcopal ground than one might assume.

Equally, the impact of these kinds of episcopal attitudes on the internal politics of the French church and, more broadly, on the international ecclesiastical scene has not been investigated to any significant degree. For instance, political histories of seventeenth-century France routinely refer to the political functions of the episcopate, whose members, like François Faure of Amiens, acted as local power brokers, governing forces and even royal ministers. ${ }^{22}$ They rarely enquire about the elastic twists that many of them required of their consciences in order to reconcile their profane responsibilities with their role as spiritual officers of the ecclesiastical realm. Similarly, over the years, many of 
the episodes that are described in this book have received attention from other scholars: the quarrel over Jansenism, the gallican crisis of the régale and the 1682 Gallican Articles all have been the subjects of several studies which highlight their political implications for the crown, the papacy and even the lower clergy. ${ }^{23}$ Yet none of them attempts to understand the positions that the episcopate assumed when it became a central participant in these contentions, by identifying the convictions that drove it to behave as it did. Why, for example, did the episcopate approve the famously anti-papal Gallican Articles of 1682 when, in contrast, the Sorbonne refused to do so until it was forced? Most historians have simply assumed that the Articles were an expression of Louis XIV's control over his bishops. ${ }^{24}$ But it is possible, and more appropriate, especially in the light of what we now know about the frailties of the so-called absolutist government of the Sun King, to explain the episcopate's action in terms that do justice to the sophisticated political and theological principles that shaped its view of papal and episcopal power. In doing so, it quickly becomes apparent that these Articles were not just a politically motivated betrayal of papal authority, but a legitimate articulation of the episcopate's ideology of ecclesiastical hierarchy and government.

Of course, the relationship between ideas and actions is complex and difficult to unravel; for this reason, scholars, who prefer to examine either one or the other, frequently ignore the symbiotic relationship linking them. Yet they then tell only half the story, for attitudes, principles and ideas play major roles in the formation of self-conscious identities and, ultimately, they regularly shape the actions and events in which identity is both manifested and perpetuated. This book, therefore, traces the dynamic interplay between ideas and events, examining the impact that conceptions of episcopacy had on key ecclesiastical events of the era, while simultaneously investigating the formative role of these incidents in the evolution of views on the episcopal office. Though what is offered here is primarily a history of ideas, it is essential to situate these within the realm of actual historical events, rather than examining them purely in the abstract. Yet in a work of this size, it is impossible to include every single episode involving the bishops in order to display the impact of episcopal ideology on events. To do so would entail writing an exhaustive history of the entire French church, since the episcopate was such a central and active body within both church and society. Just one example illustrates this: so many quarrels erupted between the episcopate and the regular clergy that it would be tedious as well as repetitive to undertake detailed narratives and analyses of all of them. Since most of these clashes hovered around identical issues of hierarchical jurisdiction and discipline, the best approach is to use representative cases from these episodes to construct a coherent overview of the ideas at work in episcopal actions; naturally these incidents include those which proved most momentous 
for the episcopate's development and those which are most revealing of the bishops' ideals and perceptions. As with any prosopographic approach, there is some risk of generalisation, but this is the most appropriate method to use if one is to preserve some degree of thematic cohesion and avoid an unwieldy catalogue of disjointed squabbles and crises.

The bishops' vision of episcopacy also provides an excellent window on to the wider development of Tridentine catholicism, for it both incorporates and demonstrates the shifts in fortune, function and style that shaped the church through this formative era. In attempting to formulate their own ideological self-conception, French bishops were, at least partially, responding to the dilemmas that their contemporary ecclesiastical, political and social environments thrust upon them. In fact, research by historians on bishops and the church outside France partly maps the way for a study that aims to shed light on the character and functioning of ecclesiastical government, hierarchy and pastoral care not only in France but throughout the Tridentine church. As John O'Malley has recently pointed out in his summary of Reformation historiography, the early modern era saw deeply significant transformations in the style, role and understanding of Catholic institutions and practices. The French episcopate both witnessed and helped to shape these changes in the organisation, government and pastorate of the church. ${ }^{25}$ It is possible to view some of those shifts through the lens of episcopal experiences and ideals because the bishops were so centrally involved in them; they were instrumental in the production of Trent's decrees; they supervised diocesan reform; they possessed the important task of governing the church as key members of the divinely ordained ecclesiastical hierarchy.

In the wake of Trent, bishops were offered some classic images to guide them in fulfilling those tasks; the work of scholars like Giuseppe Alberigo and Oliver Logan on Italian developments has pointed to the emergence of episcopal models that encouraged devotion to diocesan administration and the cultivation of virtue. ${ }^{26}$ Yet no consensus has yet been reached about the originality or impact of these images, for historians continue to debate their characteristics and the extent of the influence of reform ideas on bishops in practice. In the field of French episcopal historiography, the situation is, if anything, worse, partly because little has been done to situate the French experience within wider European currents. Beyond tentative, if repeated, efforts, to trace the influence of Charles Borromeo in France during the seventeenth century, there has been no coherent study of the transmission of ideas on episcopal functions and spirituality within the episcopate or of their concrete effects in France. ${ }^{27}$ This is a particular gap given the reinvigoration of ideas on episcopacy and the rejuvenation of the office by bishops like the two Borromeos and Valier in Italy and Barthélemy des Martyrs in Portugal during the decades following Trent. ${ }^{28}$ 
The opening chapter of this book places France within its contemporary context by analysing these wider European currents. Reflection and writing on episcopacy were certainly not phenomena peculiar to this era, but when the Council of Trent placed bishops at the heart of its reform programme it concentrated renewed attention on the nature of the office and its role within the church. In the wake of the Council, the fruits of that concentration were often published in the form of handbooks for bishops which attempted to supplement Trent's bald directives with advice on episcopal administration, spirituality and pastoral care. When this development is viewed in conjunction with the reforming actions of bishops like Borromeo and Valier and with Trent's decrees, it is clear that within the wider church, the late sixteenth century proved a very productive era for the elaboration of ideas on episcopacy. Despite the instability of the civil wars, the French church was not untouched by this discussion, and several prelates like Cardinal Joyeuse, the archbishop of Rouen, absorbed contemporary suggestions and used them to govern their dioceses before 1600. Like their contemporaries outside France, however, they found themselves tied to a particularly legalistic and long-standing notion of episcopacy which, despite the efforts of both theologians and bishops, overshadowed the pastoral and spiritual aspects of the office. This had also traditionally been a problem for reform-minded French theologians and preachers since the late medieval era, and it continued to exercise the minds of bishops and reformers into the seventeenth century.

Among the best-known and most significant of these reformers were those commonly labelled by historians as forming 'the French school' of spirituality and priesthood. French historians have generally justified their claim that France underwent a religious renaissance directly after the religious wars by pointing to this particularly gallic brand of mystical spirituality, which emerged in the early decades of the seventeenth century under the aegis of individuals like Pierre de Bérulle and Charles de Condren. Whether one accepts this contention or not, the close links between French clerical reformers and this spiritual revival are well documented. ${ }^{29}$ The school's sacerdotal theory was founded on principles of ecclesiastical hierarchy which built on the Tridentine decrees in emphasising the unique character of priesthood, the eminence of its members and their intimate relationship with Jesus Christ, the founder of their order. Through their writings and the congregations that they founded, the reformers' ideas became the dominant sacerdotal theology within the French church, and indeed went on to influence clergy outside France for several centuries.

These efforts to reform the priesthood have been amply traced: several historians have mined the abundant treatises produced on the subject, ${ }^{30}$ while detailed (if rather hagiographic) histories of the congregations and their founders have also been produced since the seventeenth century. ${ }^{31}$ Yet, almost 
invariably, historians have concentrated on the reformers' views of priesthood and on their efforts to 'sanctify' the lower clergy of France, ignoring the fact that, fired by Trent's hierarchical ambition, they also developed particularly strong theologies of episcopacy which they consistently aimed to put into practice. A handful of studies have vouched for the impact of the reformers on the theology and practice of episcopacy within France. Notwithstanding the absence of detailed evidence, they have even attempted to trace the means through which prominent reformers sought to influence the appointment of bishops in France and have referred to the 'type' of bishop that these clerics were keen to promote. ${ }^{32}$ But they have done so without initially pinpointing exactly what the reformers' objective, personified in the good bishop, actually was. Chapter 2 fills this particular gap, demonstrating that Bérulle and his disciples made crucial contributions to the development of seventeenth-century episcopal ideology through their emphasis on the superb theological character and hierarchical authority of episcopacy. By making every effort to ensure that their well-articulated ideas on the meaning, character and role of the episcopal office were passed to the bishops of France, these reformers substantially enhanced episcopal status and offered prelates an invaluable justification for their claims to extensive jurisdiction over all those within their dioceses. Again, very importantly, by highlighting the great power of bishops and the prestige of their office, the reformers fostered a sense of confidence and self-identity within the episcopate which stood bishops in good stead in their relations, frequently tempestuous, with other sections of the church and with the secular authorities.

In forging their vision of episcopacy, French bishops were obliged to take account of the attitudes, positive and negative, of other powerful interests. Particularly important was their relationship with other clergy in the Tridentine church: the regulars, the parish curés and the papacy all held robust opinions on the status and power of bishops. The histories of individual dioceses, ecclesiastics and religious orders have drawn attention, again and again, to the energetic roles of members of the lower clergy in implementing reforms at local level. ${ }^{33}$ However, while these studies make it clear that clerics often co-operated in ministering to the faithful, they also bring to light the paralysing disagreements over jurisdiction and discipline that divided bishops from their clergy. Often, they usefully describe the paths of individual quarrels, but to understand their broader impact on the French church and on the episcopate that became so enmeshed in them, it is essential to undertake a collective analysis of their prevalence, the principles at stake and the behaviour of their protagonists. ${ }^{34}$ For these disagreements reflected profoundly incompatible understandings of Tridentine reform and ecclesiastical government, and their outcomes would radically affect the locations of power and the structures of authority and government, not only within dioceses, but also within the entire church. 
Chapters 3 and 4 examine the contrasting views of episcopacy proposed by the episcopate, the lower clergy and the papacy by placing their many conflicts in the context of Tridentine ecclesiological politics. Faced with severe resistance to their discipline from the lower clergy, seventeenth-century French bishops were obliged to define and defend their rights of jurisdiction so that their monarchical authority could reign supreme in their dioceses. While the reformers' views of hierarchy and episcopal dignity were helpful to the bishops in developing their justification of episcopal status vis-à-vis the lower clergy, the very fact that the regulars and curés offered such sophisticated and vigorous arguments for their independence from their bishops forced the episcopate towards definite and categorical statements of its own convictions. Furthermore, when the regulars claimed that their papal privileges exempted them from episcopal supervision, this had enormous consequences for the bishops' relationship with the papacy. Chapter 4 explores how collusion between Rome and the regulars pushed the bishops towards a fiercely protective doctrine of episcopal gallicanism that was finally cemented in the 1682 Gallican Articles. Equally, however, the episcopate resented what it believed were Rome's efforts to undermine the traditional rights that protected its honour and authority. Ultimately, the crises over papal privileges and the trial and judgement of bishops were stark manifestations of a crucial jostle for power between two key hierarchical offices of the Tridentine church: a papacy that is often, and too readily, considered to have immeasurably enhanced its power during the early modern era and an episcopate that was determined to offset that tendency. ${ }^{35} \mathrm{In}$ all, the bishops fought with notable success to prevent a centralising Rome from converting their office into a docile agency of papal autocracy.

In their quarrels with the papacy, the bishops found, in the Assembly of Clergy, a priceless mouthpiece for their coherent views on the structure of the ecclesiastical hierarchy and their role in the government of the church. As the principal forum for contemporary French ecclesiastical affairs ${ }^{36}$ and as a body dominated by the episcopate who supplied the majority of its deputies, the Assembly proved just as instrumental in defending the episcopal power to judge matters of faith. During the 1650s, however, it clashed heavily with Jansenist bishops as a result of their different interpretations of this principle, demonstrating that the Assembly's bishops did not invariably sing from the same song-sheet as those prelates whom they claimed to represent: the majority of bishops rejected papal infallibility and favoured conciliarism, but many certainly did not agree that the Assembly should act as a national council with absolute power over every French bishop.

It was not, of course, simply to the dilemmas thrown up by Trent and reform that the episcopate had to respond. Chapter 5 addresses the episcopate's understanding of its status and its role towards another power that consistently 
sought to increase its sway over the French church: the gallican crown and its secular officials. Just as the bishops were often happy to adopt a benign language of respect and co-operation to describe the ideal relationship between the episcopate and the pope, they were willing to speak theoretically of the mutually supportive relationship between the church, its episcopal leaders and the secular realm. Equally, however, as the episcopate found in its tense relations with successive popes, this ideal was hard to put into practice, and contributed to several serious clashes between the bishops and the French crown. Ultimately, the crown held the upper hand in this delicate alliance, for the bishops were regularly obliged to compromise their principles to survive with at least a partial sense of their dignity. Yet, from the bishops' conflicts with the state and the papacy, and indeed with the lower clergy, emerged a strong sense of communion and collective identity within the episcopate, based on the belief that prelates were duty-bound to protect their office and their brethren.

The large number of hagiographic and didactic publications produced in France through the century highlight this particular ideological development, for, overwhelmingly, they reflected and disseminated the ideas and ideals formulated by bishops and reformers as they attempted to deal with actual events and situations within the church and the state. Theirs was a secondary or supportive role, through which they validated and propagated episcopal authority, privileges and prestige. It was also within these publications that the French pastoral ideal received its most detailed expression. Historians appear to have had little doubt that Charles Borromeo exerted a formidable influence on the French church and its episcopate, and Chapter 6 demonstrates the impact of the Borromean model of episcopacy on bishops through the seventeenth century. Yet it is unhelpful conveniently to categorise all reforming bishops as Borromean, for the thorough projection of this model can obscure the complex multiplicity of ideas on episcopacy and the variety of influences that shaped the French ideal of the good bishop. In fact, rather than simply adopting a single model, the French vision actually ingeniously combined the appropriate elements of the archetypes provided by Charles Borromeo and the bishop of Geneva, François de Sales. Characterised by Borromean administrative methods and Salesian Christian humanism, this pastoral ideal married governmental duties with an intense spirituality that particularly emphasised charity and interior mortification. De Sales's humane brand of charitable spirituality served as a corrective to the bureaucratic or legislative pastorate of the Borromean school, which French bishops did not consider to be either fully representative of or applicable to the role of prelates within the church. The private correspondence and compositions of bishops and other leading clergy reveal that this construct of pastoral care, spirituality and theology fulfilled a need felt within the episcopate itself and was diffused, both formally and 
informally, to provide an inspiring framework for administrative work and personal life.

The materials available for the tracing of episcopal ideology during the seventeenth century are both diverse and relatively plentiful. They are drawn from published sources and personal papers, and present a broad range of ideas drawn from a wide cross-section of the French clergy. Published sources include works of instruction for bishops, such as Les Fonctions du hiérarque parfait by the bishop of Belley (Jean-Pierre Camus) ${ }^{37}$ which systematically discuss the theological, canonical and pastoral aspects of the episcopal office. They also include texts arising from particular jurisdictional controversies of the era as well as purely spiritual works whose authors were principally concerned with elaborating their personal conceptions of episcopacy. Finally, works of hagiography and biography, of which a large number were produced in France from the 1620 s, are particularly useful for their extended descriptions of ideal episcopal virtues and modes of life. These were written with both French and nonFrench bishops as their subjects, including contemporary prelates such as Barthélemy de Donadieu and Étienne de Villazel. ${ }^{38}$ All these sources were produced for very specific audiences, hence their frequently specialised topics and their assumptions of a degree of theological literacy among their readers. Primarily, their contents were directed at contemporary bishops, though the authors sometimes encouraged other ecclesiastics to read them. Their principal aims were to educate and persuade prelates of the truth of their arguments and to guide them in their vocation. They were all designed, therefore, to produce a particular kind of bishop. Works of controversy had the further, and equally important, goal of influencing the outcomes of contemporary debates relating to episcopacy and to ecclesiastical hierarchy and government, but they too presented an episcopal ideal through their arguments. Even, therefore, if the literary merit of many publications leaves a lot to be desired, they provide excellent evidence of the evolution of mentalities and ideologies. For the opinions that they offer to their readers are not necessarily reflections of current practice, but they certainly mirror contemporary aspirations, based on the perceived needs of the episcopate, the church and society. Yet, surprisingly, given their obvious value, these sources have never been systematically examined, and they are a virtually untapped resource for the history of the seventeenthcentury French church. Many episcopal biographers have even failed to harness the writings of their subject effectively as sources for his beliefs and actions. ${ }^{39}$

Valuable evidence is also contained in private correspondence, some of which has been published, ${ }^{40}$ and in personal, and unpublished, reflections on episcopacy, usually produced by bishops for their own instruction as well as for sermons and for the education of their diocesan clergy. In addition, bishops and 
other ecclesiastics often referred to contemporary debates on episcopacy and presented justifications for their own stance in these. Fortunately, this happened regularly, for, assuming that their private writings would be restricted to a select readership, bishops were often exceptionally forthright in voicing their opinions on charged issues such as episcopal dignity and jurisdiction, papal primacy or royal power. The volume of the material contained in personal papers, not to mention in published texts, presents its own set of difficulties: the variety of potential evidence means that the sources require meticulous reading, recording and analysis before particular and general themes can be determined and conclusions ventured. They are limited too in that they probably represent only a proportion of the privately recorded views on episcopacy. Certainly, owing to problems of availability, most of the evidence is weighted towards textual sources that were intended for a public audience, but by also including personal writings, composed by various authors at different stages of the era, we possess a sufficiently composite body of material to posit general trends on episcopal ideology within the French church. ${ }^{41}$ Personal compositions provide an essential back-up to the findings of texts produced for a wide audience, enabling us to confirm the evolution and adoption of ideas. They are also, however, significant sources in their own right, often containing new as well as personal views, which would not otherwise have come into circulation and therefore would not be available to historians.

Of course, published texts can also be difficult to evaluate. Determining the extent of their readership is a hazardous task, though the number of editions indicates that, in general, they were in demand. This has not been a significant difficulty in the case of this project, however; since it is essentially a study of the evolution and adoption of ideas rather than of their circulation, exact readership numbers are not of primary concern. Rather, the aim is to examine the birth and absorption of ideas, principally within the episcopate, and this can be achieved by careful examination of the appropriation of particular views and by noting the references made by contemporaries to specific texts. The composition and publication dates of individual texts and correspondence assume a special significance in this context.

Overwhelmingly, it was ecclesiastics who produced these publications on episcopacy, and the reader may consider that the laity are under-represented in this study. Lay views have been incorporated whenever possible, although the evidence is admittedly dominated by the observations and actions of elite laymen, such as government officials and the nobility. On the other hand, it is much more difficult to ascertain precisely what the peasantry thought about episcopacy as an abstract concept or even about their bishops in practice. An even greater minefield would be to track the interplay between their visions of episcopal behaviour and bishops' attitudes towards leadership and government. ${ }^{42}$ 
It is certain, however, that for many of the peasantry, their bishop was a remote figure, seen only if and when he made his visitation of their parish. Instead, their parish priest, resident among them, was the peasantry's principal point of contact with the clergy of their church. Very little evidence still exists, if it ever did, to enable the historian to trace the laity's 'ideal' bishop, or his impact on prelates, and what remains is so scattered that it would require a complete project to construct a coherent overview. However, an enhanced appreciation of the episcopate's own ideals and world view is surely a prerequisite for this.

What is offered here, then, is a broad presentation and analysis of views within the French church that, above all, enables us to understand what bishops thought about their office, why they did so and how it affected their behaviour. By drawing on the wide range of published and private material, the chapters that follow provide a composite and comprehensive image of the ideal bishop, as it was perceived by French bishops themselves and by their contemporaries, and as it shaped the Tridentine church. What follows, therefore, is not primarily a study of events, but one of mentalities and ideas and of the many ways in which they interplayed with events. Its purpose is to expand significantly our understanding of an extremely influential seventeenth-century elite and of the culture of the Catholic church during this formative period.

\section{Notes}

1 Joseph Bergin, 'The Counter-Reformation Church and its Bishops', Past and Present, 165 (1999), 30-73, at 30.

2 Nor to Protestant churches in which bishops remained as the heads of dioceses. For the attempts by Anglican bishops to adjust to the Reformation by references to Pauline and apostolic imagery, see Kenneth Fincham, Prelate as Pastor. The Episcopate of James I (Oxford 1990).

3 André Deroo, Saint Charles Borromée (Paris 1963); Ruth Kleinman, Saint Francis de Sales and the Protestants (Geneva 1962).

4 Hubert Jedin, A History of the Council of Trent, trans. Ernest Graf, 2 vols (London 1957-61).

5 Hubert Jedin, L'Evêque dans la tradition pastorale du xvi siècle, ed. Paul Broutin (Brussels 1953).

6 Henry Outram Evennett, The Spirit of the Counter-Reformation (Cambridge 1968).

7 For example: Michael Carroll, Veiled Threats. The Logic of Popular Catholicism in Italy (Baltimore and London 1996); Stephen Haliczer, Sexuality in the Confessional. A Sacrament Profaned (New York and Oxford 1986); David Sabean, Power in the Blood. Popular Culture and Village Discourse in Early Modern Germany (Cambridge 1984).

8 Jean Delumeau, Sin and Fear. The Emergence of a Western Guilt Culture 13th-18th Centuries, trans. Eric Nicholson (New York 1990); Gabriel Le Bras, Etudes de sociologie religieuse, 2 vols (Paris 1955); Gabriel Le Bras, L'Eglise et le village (Paris 1976).

9 Jonathan Dewald, Aristocratic Experience and the Origins of Modern Culture. France 1570-1715 (Berkeley and Oxford 1993); Alexander Sedgwick, Jansenism in Seventeenth-Century France. Voices from the Wilderness (Charlottesville, Virginia 1977).

10 Keith Luria, Territories of Grace. Cultural Change in the Seventeenth-Century Diocese of Grenoble (Berkeley and Oxford 1991); Bernard Peyrous, La Réforme catholique à Bordeaux (16001719), 2 vols (Bordeaux 1995); Robert Sauzet, Contre-réforme et réforme catholique en basLanguedoc. Le diocèse de Nîmes au xviie siècle (Louvain and Paris 1979).

11 Luria, Territories, pp. 44-5. 
12 Paul Broutin, La Réforme pastorale en France au xviie siècle, 2 vols (Paris and Tournai 1956).

13 Joseph Bergin, Cardinal de La Rochefoucauld. Leadership and Reform in the French Church (New Haven and London 1987); Isabelle Bonnot, Hérétique ou saint? Henri Arnauld, évêque janséniste d'Angers au xviie siècle (Paris 1983); Bernard Peyrous, 'La Réforme institutionnelle de l'archidiocèse de Bordeaux au temps du cardinal François de Sourdis (1599-1628)', Revue d'Histoire Ecclésiastique, 76 (1981), 5-47.

14 Michel Péronnet, Les Evêques de l'ancienne France, 2 vols (Lille 1978).

15 Norman Ravitch, Sword and Mitre: Government and Episcopacy in France and England in the Age of Aristocracy (The Hague 1966); J. Michael Hayden, 'The Social Origins of the French Episcopacy at the Beginning of the Seventeenth Century', French Historical Studies, 10 (1977), 27-38.

16 Joseph Bergin, The Making of the French Episcopate 1589-1661 (New Haven and London 1996).

17 Bergin, 'Counter-Reformation'; Fincham, Prelate, pp. 9-18, 248-93.

18 Bergin, Episcopate, pp. 224-7.

19 Hayden, 'Origins', 33.

20 Victor Martin, Le Gallicanisme politique et le clergé de France (Paris 1929).

21 Pierre Blet, 'L'Idée de l'épiscopat chez les évêques français du xvii siècle', in Bernard Vogler (ed.), L'Institution des pouvoirs dans les églises de l'antiquité à nos jours (Louvain 1987), pp. 311-23; Raymond Darricau, 'L’Evêque dans la pensée de Saint Vincent de Paul', Divus Thomas, 84 (1981), 161-88; Raymond Darricau, 'L'Evêque chez les spirituels français', L'Evêque dans l'histoire de l'église (Angers 1984), pp. 109-22; Réné Taveneaux, 'L'Evêque selon Port-Royal', Jansénisme et réforme catholique (Nancy 1992), pp. 75-87.

22 Sharon Kettering, Patrons, Brokers and Clients in Seventeenth-Century France (New York and Oxford 1986), pp. 124-5; Roger Mettam, Power and Faction in Louis XIV's France (Oxford and

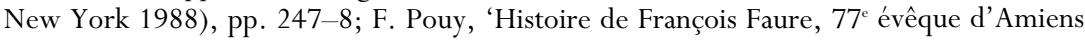
1612-87', Mémoires de la Société des Antiquaires de Picardie, 25 (1876), 137-286.

23 Richard Golden, The Godly Rebellion. Parisian Curés and the Religious Fronde 1652-1662 (Chapel Hill, North Carolina 1981); Martin, Gallicanisme politique.

24 Charles Gérin, Recherches historiques sur l'assemblée du clergé de France de 1682 (Paris, 2nd edition 1870), p. 68; Joseph Le Maistre, Du pape, suivi de l'église gallicane dans son rapport avec le souverain pontife, 2 vols (Brussels 1852); Jean Orcibal, Louis XIV contre Innocent XI (Paris 1949), p. 7; Mettam, Power, p. 251.

25 John O'Malley, Trent and All That. Renaming Catholicism in the Early Modern Era (Cambridge, Massachusetts and London 2000), p. 67.

26 Giuseppe Alberigo, 'L'Episcopato nel cattolicesimo riformato xvi-xvii secoli', in Bernard Vogler (ed.), Miscellanea Historiae Pontificiae, viii (Brussels and Louvain 1987), pp. 268-86; Oliver Logan, The Venetian Upper Clergy in the Sixteenth and Early Seventeenth Centuries (New York and Queenston, Ontario 1996), p. 23. See also Christopher Cairns, Domenico Bollani Bishop of Brescia. Devotion to Church and State in the Republic of Venice in the Sixteenth Century (Nieuwkoop 1976), and Paolo Prodi, Il cardinale Gabriele Paleotti (1522-1597), 2 vols (Rome 1959).

27 Marcel Bernos, 'Saint Charles Borromée et ses "Instructions aux confesseurs". Une lecture rigoriste par le clergé français (xvie-xixe siècle)', Pratiques de la confession (Paris 1983), pp. 185-200; Bernard Plongeron, 'Charles Borromée, exemple et modèle: son influence en France (xvie-xixe siècles)', San Carlo e il suo tempo (Rome 1986), pp. 493-525; Marc Venard, 'The Influence of Carlo Borromeo on the Church of France', in John M. Headley and John B. Tomaro (eds), San Carlo Borromeo. Catholic Reform and Ecclesiastical Politics in the Second Half of the Sixteenth Century (Washington 1988), pp. 208-27.

28 Raul de Almeida Rolo, L'Evêque de la réforme tridentine. Sa mission pastorale d'après le vénérable Barthélemy des Martyrs, trans. Ceslas Salmon (Lisbon 1965).

29 Jean Dagens, Bérulle et les origines de la restauration catholique (1575-1611) (Bruges 1952); Eugene Walsh, 'The Priesthood in the Writings of the French School: Bérulle, De Condren, Olier' (PhD dissertation, Catholic University of America, Washington DC 1949). 
30 P. Cochois, 'Bérulle, Hiérarque Dionysien', Revue d'Ascétique et de Mystique, 37 (1961), 314-53; 38 (1962), 355-75; Dagens, Bérulle; Michel Dupuy, Bérulle et le sacerdoce. Etude historique et doctrinale (Paris 1969); Yves Krumenacker, L'Ecole française de spiritualité (Paris 1998); Nicole Lemaître, 'Le Prêtre mis à part ou le triomphe d'une idéologie sacerdotale au xvie siècle', Revue d'Histoire de l'Eglise de France, 85 (1999), 275-89; Walsh, 'Priesthood'.

31 Étienne-Michel Faillon, Vie de M. Olier fondateur du séminaire de Saint-Sulpice, 3 vols (Paris, 4th edition 1873); André Pioger, Un orateur de l'école française. Saint Jean Eudes (1601-80) (Paris 1940); José María Román, St Vincent de Paul. A Biography, trans. Joyce Howard (London 1999).

32 Bergin, Episcopate, pp. 513-17; Pierre Blet, 'Vincent de Paul et l'épiscopat français', Vincent de Paul. Actes du Colloque International d'Etudes Vincentiennes (Rome 1983), pp. 81-114; Broutin, Réforme, ii, pp. 252-7; Réné Taveneaux, Le Catholicisme dans la France classique, 1610-1715, 2 vols (Paris 1980), i, pp. 111-13.

33 Louis Châtellier, The Religion of the Poor. Rural Missions in Europe and the Formation of Modern Catholicism, c.1500-c.1800 (Cambridge 1997), pp. 7-92; Philip Hoffman, Church and Community in the Diocese of Lyon 1500-1789 (New Haven and London 1984), pp. 74 83, 98-118, 128-38; Sauzet, Contre-réforme, pp. 134 41, 354-9, 442-54.

34 This has not been a feature of previous studies of the lower clergy, the episcopate and the papacy: Charles Chesneau, Le Père Yves de Paris et son temps (1590-1678), 2 vols (Paris 1946); Marc Dubruel, 'Hiérarchie gallicane et religieux exempts. Un épisode de leurs relations au xvii ${ }^{\text {e }}$ siècle. Caulet et les Jésuites', Recherches de Science Religieuse (1919), 324-68; (1920), 55-91; Golden, Rebellion; Orcibal, Louis XIV.

35 Evennett, Spirit, pp. 89-125; Paolo Prodi, The Papal Prince. One Body and Two Souls. The Papal Monarch in Early Modern Europe, trans. Susan Haskins (Cambridge 1987); Thierry Wanegffelen, Une difficile fidélité. Catholiques malgré le concile en France xvie-xviie siècles (Paris 1999).

36 When the Contract of Poissy (1561) established the Assemblies on a permanent basis their remit was to decide the clergy's financial contribution to the crown and to submit complaints to the monarch. Although their brief did not officially encompass issues of jurisdiction and organisation, the Assembly's deliberations had by the 1620 s embraced all issues affecting the well-being of the church.

37 Jean-Pierre Camus, Les Fonctions du hiérarque parfait, où se voir le tableau de l'évesque que accomply (Paris 1642).

38 Étienne Molinier, La Vie de Mre. Barthélemy de Donadieu de Griet évesque de Comenge (Paris 1639); Jean-Baptiste Noulleau, Le Modele d'un grand évesque: d'un parfait prédicateur: d'un directeur des âmes accomply: d'un vray politique chrétien. En la personne de feu Messire Estienne de Villazel, très-digne évesque de S. Brieu (Paris 1665).

39 L.-W. Ravenez, Histoire du cardinal François de Sourdis (Bordeaux 1867), is strong on the facts of Sourdis's life but virtually silent upon his theological beliefs and spiritual motivations.

40 A substantial amount of, for example, Alain de Solminihac's correspondence and private notes has been published: Alain de Solminihac, Alain de Solminihac. Lettres et documents, ed. Eugène Sol (Cahors 1930).

41 Such as the letters of Pierre de Bérulle, composed during the 1610s and 1620s, and those of Antoine Godeau, bishop of Grasse, written from the late 1630s to his death in 1673: Pierre de Bérulle, Correspondance du cardinal Pierre de Bérulle, ed. Jean Dagens, 3 vols (Paris and Louvain 1937-9); Antoine Godeau, Lettres de M. Godeau, évesque de Vence, sur divers sujets (Paris 1713).

42 Though here also, diocesan histories, such as Luria's study of Le Camus's episcopate in Grenoble, are beginning to offer helpful insights. 


\section{1 \\ Catholic renewal and episcopal traditions in the sixteenth century}

In the eyes of its Catholic contemporaries in the early 1560s, the French episcopate must have appeared to be in an enviable position. A highly influential role in the formulation of the Council of Trent's reform programme left its mark for posterity in the shape of the final decrees and earned its members the respect of the entire Catholic church, an impression not lessened by the fact that the French delegation had only been present at the Council's final sessions (1562-63). At the Council, the bishops had been led by the charismatic and widely renowned Cardinal Charles de Lorraine, archbishop of Reims and advisor to the French monarchy, who returned to France well satisfied with the outcome of his negotiations on behalf of the French church and crown. ${ }^{1}$ This impression of episcopal dynamism and confidence was also fed by the fact that throughout their sojourn at Trent, the French delegates had displayed such signs of enthusiasm for Catholic reform that it seemed very likely they would soon become models of Tridentine leadership for bishops throughout Europe.

In reality, these expectations were not fulfilled. Most historians, as well as those contemporaries best placed to assess their bishops, present a very different picture of the post-Tridentine episcopate in France. Both contemporaries and historians have frequently drawn attention to abuses within the episcopate, predictably focusing on the exploits of infamous individuals within its ranks, such as those who converted to protestantism or who lived particularly scandalous lives. Perhaps this is inevitable, for as one leading historian of the ancien régime church has remarked, 'Just as the Devil has the best tunes, so the affairs of the world provide the historian with better evidence than fervour and devotion. ${ }^{2}$ Yet this preoccupation with vice and abuse means that historians have judged the episcopate to be a highly worldly body, controlled by the crown and powerful aristocratic families, who used bishoprics as pawns in their political games: the classic example cited is the 'turbulent ambition' of Charles de Lorraine. ${ }^{3}$ This overwhelmingly negative view is perhaps understandable in view of the frequently uncomplimentary opinions expressed by contemporaries on the 
state of the episcopate and in view of the notoriety of prominent individual prelates, such as Jean de Monluc of Valence, royal diplomat, member of the Conseil d'État and alleged heretic. ${ }^{4}$ The abbot of Cîteaux famously complained at the 1579 Assembly, and he has often since been quoted by historians, that the king was in the process of gradually losing control of nominations since most of the benefices were in the hands of the leading noble families, 'who regarded them as hereditary'. 5

Even allowing for some exaggeration and imbalance in the citing of episcopal inadequacies and for the subjective nature of much of the source material, there is no doubt that by the final decade of the sixteenth century the French episcopate was in a state of considerable disarray and that the criticisms of contemporaries and the judgements of historians do have a reasonable basis in fact. Despite its promising start, the late sixteenth-century episcopate failed to live up to the expectations which it and others held for its future. Indeed, it was not French bishops who assumed the mantle of leadership within the late sixteenth-century church. Instead, prelates outside France acted as the vanguards of episcopally led reform, and it was to these figures that the French had to look for guidance and encouragement in any efforts to implement Trent's decrees within their dioceses. Yet how did the episcopate reach this state of affairs in the wake of its triumph at Trent? It was partly due to the fact that, just as the delegates returned to France, the country plunged into the wars of religion (1562-98) which were to cripple it for virtually the remainder of the century. Additionally, the episcopate itself was burdened with several institutional abuses that made the implementation of reforms extremely difficult for even the most dedicated of prelates.

In the first place, research has pointed to the geographical dislocation and economic difficulties caused by the wars of religion and to the resulting difficulties for bishops in fulfilling the functions of their office. ${ }^{6}$ In 1594, Cardinal de Joyeuse complained that two of the eight dioceses in Toulouse province still remained under the 'heretic curse'. ${ }^{7}$ Huguenot occupation of episcopal lands and temporalities was accompanied by the potentially even more fundamental danger of the Calvinist threat to the very existence of the episcopal office itself, for the reformed faith denied that bishops were necessary at all. Its menace assumed ominous proportions when bishops themselves succumbed to heresy, and either abandoned their dioceses or were excommunicated by Rome. In fact, French protestantism succeeded in winning a number of high-profile prelates to its cause, about twelve in all, and seven bishops were condemned for heresy by Rome in $1566 .{ }^{8}$ Some conversions and resignations were rather spectacular, attracting significant public attention both within and outside France, and included the notorious and tragic dilemma of Antonio Caracciolo, bishop of Troyes, who unsuccessfully tried to persuade both Geneva and his 
disapproving flock that he could remain a bishop while acting as pastor of the local Calvinist, rather than Catholic, church!'

Certainly, demoralised bishops were not themselves slow to blame the wars and the Huguenots for their failure to operate within their dioceses, complaining of protestant aggression towards their persons and property and of economic destitution which, to quote another bishop of Troyes, Claude Bauffremont, resulted in diocesan 'losses and almost infinite ruin'.$^{10}$ Yet this was not the only reason for episcopal dishevelment. For its contemporary critics, the episcopate's innate flaws cut much deeper. While conceding that the wars were at least partly to blame for the inadequacies of the episcopate, they also lambasted what they believed to be the worldly nature of the office by the late sixteenth century. They agreed that a major contributor to this worldliness was the Concordat of Bologna, the agreement between François I and Leo X in 1516 which officially dispensed with the episcopal elections prescribed under the terms of the 1438 Pragmatic Sanction of Bourges, and reserved episcopal nomination to the French monarch, subject to papal confirmation. ${ }^{11}$ Indeed, calls for the abolition of the Concordat and a return to episcopal elections by chapters would continue right through the succeeding century, though to no avail and with a consequent increasing sense of formalism. Still, complaints about the Concordat did have a basis in fact, since the system allowed successive kings to use episcopal appointments as rewards for service or as means to secure and preserve order within provinces.

It is not difficult to find cases to illustrate this tendency: a substantial number of French dioceses were granted to Italian bishops during the decades subsequent to the Concordat's introduction. Members of prominent Italian families who had supported the French crown during its struggle with the Habsburgs for control of Italy were granted bishoprics, as were a number of pro-French curial figures. Italian names, such as Farnese and Ridolfi, crop up regularly among episcopal appointees through the sixteenth century. ${ }^{12}$ Although this particular use of episcopal benefices declined under Henri IV at the turn of the century, he too did offer some appointments in reward for political services and loyalties. Overall, it appears that the reign of the first Bourbon monarch brought some stability to the French episcopate, with relatively few transfers occurring between bishoprics, but his pragmatic approach to appointments still contributed to the continued fragmentation of the episcopate. Like his predecessors, he viewed diocesan sees as valuable elements of his political patronage and he was prepared to use them in negotiations aimed at stabilising the realm. Increasingly, after 1593, as the political tide turned in his favour, he offered benefices in return for loyalty to his newly established reign. Renaud de Beaune, archbishop of Bourges, was granted a transfer to the far wealthier see of Sens, in reward for his sustained support of the new king 
through the 1590s. ${ }^{13}$ Among others, rewards were made to the future cardinal Jacques Du Perron, René de Daillon du Lude and René Benoist, who received the sees of Evreux, Bayeux and Troyes respectively in return for their allegiance to the Bourbon cause. ${ }^{14}$

The tendency of the crown to view bishoprics as means of promoting order and rewarding loyalty was accompanied and encouraged by, indeed relied on, the compliance of its most prominent subjects. In fact, the more the crown used appointments as rewards, the more likely its subjects were to see them purely in this light and to react accordingly. Actually, as the research of Michel Péronnet and others demonstrates, the crown was, in several areas, completely dependent on local support in its choice of candidates and it was often the wishes of local magnates which determined appointments. ${ }^{15}$ Prominent families regarded bishoprics as their lineal property to be exploited to retain their status and power, an assumption which was maintained into the seventeenth century, despite a new emphasis on episcopal responsibility and fitness for office. Virtual hereditary tenure went hand in hand with pluralism and simony, as just cursory examination of the records of episcopal appointments shows. The Gondi clan provided Paris with four successive bishops and archbishops between 1568 and 1661, concluding its extended dominance with the disgraced Cardinal de Retz. ${ }^{16}$ Among other seventeenth-century prelates who owed their seats to this state of affairs were Philibert Du Sault, who succeeded his uncle to Dax in 1623, and Henri de Sourdis of Bordeaux, successor to his brother in $1628 .{ }^{17}$ Pierre III and Henri de Villars were successively archbishops of Vienne in the south-east of France between 1626 and 1693, Pierre III having initially succeeded Jérome de Villars as incumbent of the diocese. In fact, this particular family perfectly illustrates the strong claim to hierarchical appointments among the nobility of the sixteenth and seventeenth centuries, since it provided between 1561 and 1693 no fewer than eight bishops within the French church, to the dioceses of Mirepoix, Agen and Vienne. ${ }^{18}$

This presumption had led to what was by then the common practice of holding bishoprics en confidence. ${ }^{19}$ Henri IV selected a significant number of commoners as prelates: from one hundred and thirty bishops appointed between 1594 and 1610, thirty-six were members of the third estate. ${ }^{20}$ While this might appear to suggest a move away from confidence and control of bishoprics by leading aristocratic houses, this was not the case in actuality, since a considerable number of these bishops were dependants of noble families, chosen by them in order to ensure their continued control of the bishopric until a time when a family member was of age to be named prelate. As part of its efforts to highlight ecclesiastical abuses within the French church, the 1579 Assembly identified eight dioceses then thought to be under such arrangements, some of which were controlled by leading ecclesiastics like Cardinal de Birague, Charles de Bourbon 
and Renaud de Beaune. A decade later, the figure may have been as high as sixteen. ${ }^{21}$ Many of these interim bishops were members of religious orders or chapters or diocesan administrators and thus experienced in ecclesiastical affairs. Yet the fact remains that the practice of confidence was an institutional abuse which allowed aristocratic control of church temporalities and a secular view of the episcopal office to be maintained.

It is fair to say that the status of bishops was in this period lower than at any other time during the ancien régime. However, this assessment relates to just one aspect of the episcopal office as it was understood at this point, the secular or political facet of episcopacy, and it is this negative and spicy feature that has generally received most attention from historians. A handful of scholars have attempted to redress the balance by drawing attention to individual reforming bishops, such as Guillaume Briçonnet of Meaux, François d'Estaing of Rodez and Claude de Longwy of Mâcon, indicating that the episcopate was subject to variety in the quality of its members and that it did contain numerous prelates who took their vocation and duties seriously. Even before Trent, these men had initiated disciplinary reforms, presided over synods and fostered public preaching. ${ }^{22}$ Importantly too, the episcopate's contemporary critics did not limit themselves to negative commentaries on its inadequacies. Rather, a long tradition of reflection and writing on episcopacy, an office considered to be as old as the church itself, existed within France by the beginning of the seventeenth century. For those who chose to look, some very positive notions of what it meant to be a bishop and of the precise nature of the episcopal office were available in both printed and oral form. This tradition drew on ancient and medieval teachings, some of which were particular to France and some of which had been absorbed into the French church from external sources. Taken as a whole, these ideas and assumptions relating to the theological, spiritual, canonical and jurisdictional qualities of episcopacy provided guidelines for bishops, though not a complete or definitive image of what made a worthy bishop.

Undoubtedly, the most mature of these ideas were those that described a bishop's administrative duties. Certainly it was to this element of the office that preachers and theologians devoted most attention when they discussed episcopacy, and it was also the aspect that the Council of Trent discussed with the greatest degree of success. It is well known that the Council's entire programme of ecclesiastical reform was founded on the assumption that diocesan bishops were the key hierarchical figures for ensuring religious discipline and order. ${ }^{23}$ To this end, they were equipped with powers of government and discipline over both clergy and laity, and a system of close supervision was proposed to enable them to fulfil these functions. If this order was to be implemented residence was essential, and strict penalties were to be imposed 
for absenteeism. ${ }^{24}$ Through a system of annual diocesan visitations and synods the bishop would progressively bring religious order to his territory. To complete the framework, triennial provincial councils would be attended by all bishops 'for the regulation of morals, the correction of abuses, the settlement of controversies'. ${ }^{25}$

It was in its administrative programme for bishops that the Council proved most penetrating and categorical. This programme was not original to Trent, but was brought to the Council by the delegates who participated in its debates and who voiced ideas and proposals on episcopal administration which had circulated within the church for decades and even centuries. In particular, calls for diocesan bishops to institute reform through synods were hardly new in the Catholic church, and several councils had already commissioned their implementation three hundred years before Trent. ${ }^{26}$ That a markedly strong tradition of administrative episcopalism existed within the French church is evident from the recommendations of the Colloquy held in Poissy in September 1561, ostensibly with the purpose of reaching some reconciliation between the Huguenot and Catholic factions in France. Rather misleadingly labelled a 'colloquy', however, it could never really achieve any hope of accommodation given that Catholic clergy dominated the meeting and deigned to hear Huguenot discourses only after considerable pressure from an increasingly uneasy and vulnerable crown. ${ }^{27}$ But although the assembly did not halt the accelerating slide towards outright civil war in April 1562, the episcopal participants (three archbishops and forty-two bishops) claimed the opportunity to produce disciplinary articles which related particularly to the administrative duties of Catholic prelates, demonstrating their dawning awareness that internal reform of the Catholic church, and in particular of its episcopate, was a vital response to the spread of protestantism. In order to offset heresy, therefore, bishops had to be resident, regularly undertake diocesan visitations and synods, ensure that only worthy candidates were promoted to holy orders and live modest lives. ${ }^{28}$ These recommendations were then presented by the French episcopate at the final session of the Council of Trent, as part of the thirty-four articles which comprised the French programme of reform. Their similarity to the Council's final disciplinary decrees is incontestable. ${ }^{29}$

In formulating this programme, the French episcopate borrowed from sources circulating within their own church. Over the course of the fifteenth and sixteenth centuries, a community of sentiments on an administrative programme of ecclesiastical reform had evolved within France, and was easily accessible in print. Piton's research, supplemented by that of other historians, identifies a vocal body of individual preachers and theologians who, while not forming a cohesive reform group, did emphatically and consistently proclaim the urgent need for renewal within the church and based their hopes for its 
achievement on bishops. ${ }^{30}$ Within its ranks were influential and widely respected ecclesiastics from several generations, including Jean Gerson, the former chancellor of the University of Paris, and his fellow theologian Josse Clichtove, but their ranks also included well-known preachers like François Le Picart, Jacques Merlin and Guillaume Pepin, who were contemporaneous with Trent. These men represented several points on the ecclesiastical spectrum: all were highly educated, and held doctorates in theology from famous French universities, several were appointed bishops or vicars-general at some stage in their careers, while others had extensive pastoral experience as preaching members of mendicant orders or as diocesan clergy. ${ }^{31}$ Although they emerged from very different milieux and enjoyed varying career paths, they shared the fundamental view that immediate reform of the church was absolutely essential, that it was dependent on bishops, and that their present standard was far too low for reform to succeed. The experienced preacher Guillaume Pepin succinctly expressed their disenchantment with the contemporary episcopate when he complained that there were far too few 'Ambroses' in the French church of the sixteenth century or, in other words, too few bishops prepared to pursue God's interests. ${ }^{32}$

Once Protestant ideas began to filter into France from the 1520s, the reformers saw the need to remedy the episcopate's ills as especially pressing. Part of their response to the anti-episcopal stance of French Protestants was to emphasise the necessity for bishops within the institutional church and for successful reform with even greater urgency. Their plan of campaign was uncompromising: they agreed that episcopal residence was vital, and believed that the major stumbling block to its fulfilment was the insidious vice of worldliness which encouraged absenteeism and the involvement of bishops in 'profane affairs' ${ }^{33}$ Of course, this was a particularly pertinent observation in the postConcordat age when so many bishops owed their appointments to familial influence or power politics, and when prominent prelates like the Cardinals Lorraine and Amboise played major roles in the politics of the realm. In response to this tendency, the reformers attempted to rework traditional ideas, by laying particular stress on the non-political nature of the episcopal office and on the responsibility of bishops to be present in their sees and active in their ecclesiastical duties. Linked to these demands were their condemnations of the related practices of under-age appointments and multiple benefice-holding, ${ }^{34}$ each of which were consequences of the tendency to regard the episcopate as a quasi-hereditary and secular office. Once a bishop had been chosen, he was obliged to fulfil his administrative duties. In this context, the reformers emphasised, visitations and synods were the twin essentials enabling a bishop to implant reform. ${ }^{35}$

Obviously, therefore, Trent's model of administrative episcopacy was not radically new but was based on ideas which had long circulated within the 
church and which those seeking reform had attempted to formulate according to the perceived needs of the church. The value of the Council's legislation lay in the fact that it gave official and codified form to what had formerly been a loose conglomerate of reform principles and proposals. Yet although it scored a decisive success in this, it did not prove nearly so comprehensive about other key aspects of episcopacy. Even during the Council's deliberations, many deputies anticipated the potential risks of limiting its definitions on episcopacy, and they lost no energy in bringing this fact to their confreres' notice. As a result, when the French delegation left its own country newly embroiled in a religious war, it arrived, in November 1562, at a Council that was itself in grave danger of escalating into a full-scale war of words, followed by a divisive and inconclusive termination of debate. This struggle hinged on the issue of episcopal droit divin, that is, on the source and the nature of bishops' jurisdiction. It had been causing difficulties for quite some time; the question had first been broached in 1546 when the Council had discussed the duty of episcopal residence, and successive delegates had requested that residence be made a condition of divine law. Even after a great deal of intense debate in special committees and in the Council's main sessions, no unanimous decision could be reached on whether a positive statement on the immediate source of bishops' jurisdiction should be included in the decrees on residence. The final decrees of Session VI had simply commanded, as a result, that bishops be resident within their dioceses, but made no reference to the broader issue of droit divin (divine law or right). ${ }^{36}$

One might ask why the rationale behind a bishop's jurisdiction actually mattered so long as he exercised his diocesan authority vigilantly for the sake of reform. In reality, however, as the conciliar fathers were acutely aware, the issue of whether a bishop's jurisdiction was held according to droit divin was open to two conflicting interpretations, both with grave implications for the functioning of authority and discipline and for the hierarchical structures underpinning the institutional church. The first argued that bishops received their power of jurisdiction directly or immediately from God and that this was an inalterable principle of divine law. Alternatively, and this was the position maintained by the papacy and its zelanti supporters, one could claim that prelates derived their power of jurisdiction directly or immediately from the pope, who alone held jurisdiction in plenitude, and that the droit divin of episcopal jurisdiction was consequently without foundation. ${ }^{37}$ Each involved two distinct conceptions of ecclesiastical government, one papalist, the other more episcopalist, and, with such fundamental principles at stake, it was a quarrel that caused severe, and ultimately unresolved, difficulties at Trent.

The traditional interpretation of the French role at Trent presents the stance of the French delegation as unrepentantly confrontational, with the 
recalcitrant deputies locked in debate with the papacy over the question of bishops' jurisdictional droit divin almost as soon as they set foot in the Council's debating chambers. ${ }^{38}$ This view is not wholly accurate since, in actuality, as Tallon's investigation of the French experience at the Council demonstrates, the French delegates, and in particular their leader, Cardinal de Lorraine, considered the question of jurisdictional droit divin to be secondary to that of ecclesiastical reform. They were far more interested in the practical means by which the church could combat heresy than in debates about doctrinal issues. This was understandable since the French were faced with the rising power of the Huguenots in France and with the prospect of prolonged civil war, but it meant that they were willing to compromise upon the issue of droit divin and even to suggest that it be dropped completely from discussions. ${ }^{39}$ When they arrived at Trent, consequently, their priority was to resolve the damaging quarrel that had arisen before their participation. Lorraine's initial address to the Council stressed that the delegates must at all costs avoid creating further rifts. Indeed, although all the French prelates supported the theory of bishops' jurisdictional droit divin, only three explicitly requested that the Council officially confirm it. Even so, none was willing to allow the papacy to exploit the situation by manoeuvring an express confirmation of papal jurisdiction over the entire church, the contrary doctrine to episcopal droit divin. So, while the papal legates and zelanti continued to argue trenchantly for confirmation of this doctrine through the final months of the Council, they were opposed just as robustly by the French and Spanish bishops. ${ }^{40}$

This failure of the Council to pronounce on the issue of droit divin was a critical omission. The dispute had profound possible repercussions for the jurisdictional authority and powers of bishops and the pope, and indeed for the authority of bishops over the lower clergy. In this sense, the quarrel over residence was not, in fact, about residence at all. On the surface, the call for residence to be made a precept of divine law represented a concerted attempt to halt the practices of absenteeism and pluralism which the delegates believed to plague the church. Part of the difficulty here was the willingness of successive popes to provide bishops with dispensations for multiple benefice-holding and prolonged absences from their dioceses, policies which simply compounded the obstacles to reform. A positive connection between episcopal residence and droit divin would put paid to such abuses. But there existed a second, broader, aspect to the question of residency, and it was this that really underlay the stand-off at the Council. All the fathers knew that residence and jurisdiction were intrinsically linked, for if a bishop was to exercise his jurisdiction effectively then he had to reside in his diocese. Yet this was only the thin edge of the wedge, for if Trent had officially confirmed that residence was a divinely ordained precept, it could subsequently have been argued that all episcopal 
jurisdiction was held immediately from God. That thesis severely limited papal jurisdiction over bishops and in dioceses, denying the pope the right to interfere not only in the residence of bishops but also in their exercise of jurisdiction over their clergy and laity. It drastically curtailed, therefore, papal power through the church. Yet the final decree made no reference to the origin of episcopal powers of jurisdiction; this was the compromise which the delegates found themselves forced to concede if the Council was not to flounder and break up in disarray. This meant, however, that it remained unclear whether the jurisdiction of bishops was directly derived from God or the pope. Conceivably, both interpretations of the issue could be supported and further developed in the Council's wake, because no official doctrine existed.

Once more, the quarrel reared its head when the Tridentine delegates turned to formulating the decrees on the sacrament of order between October 1562 and July 1563. After a replay of the divisions over episcopal residence, the Council finally decreed that the priestly orders 'truly and properly' formed one of the seven sacraments, imprinting a unique and ineffaceable character on its recipients which enabled them to consecrate the bread and wine and forgive sins. Priests were distinct from and superior to the laity, therefore, because of the character and powers of their sacerdotal vocation, and the Council produced a plethora of regulations regarding clerical education, ordination and manner of life which were designed to ensure that Catholic clergy would conform to their defined role. ${ }^{41}$ Bishops too belonged to 'this hierarchical order' but were distinct from and superior to priests as a result of their charismatic authority to govern as successors of the Apostles and as a result of their charismatic ability to confer the sacraments of ordination and confirmation. ${ }^{42}$ Here, the Council plumped for the dominant scholastic distinction between episcopal order (bishops' power to confer order and to confirm) and jurisdiction (their power to govern). As the theology of priesthood had evolved during the medieval period, leading theologians, including such luminaries as Peter Lombard and Thomas Aquinas, had argued just this question. ${ }^{43}$ Aquinas concluded it to his satisfaction by positing distinctions of order and of jurisdiction between priest and bishop, while concurrently maintaining that both formed part of the same sacrament. The episcopate, he claimed, was not merely an extension of the priesthood but a discrete ecclesiastical state blessed with the powers of perfecting and jurisdiction. ${ }^{44}$ Although Trent adopted this distinction it deliberately avoided discussing its subtle theology since to do so would risk raising once more the question of the source of episcopal jurisdiction, a trap that the delegates were desperate to evade. In doing so, it failed, again, to respond to the logical questions: did episcopal jurisdiction come directly from God or indirectly via the pope, and secondly, precisely what degree of independent jurisdiction could a bishop expect to possess within his diocese? 
A persistent tradition of gallican independence made the French delegation especially sensitive to these complex questions of ecclesiastical jurisdiction, and it functioned as one of the major motivations for their stance at Trent. By the sixteenth century, ecclesiastical gallicanism had become associated with the loosely defined 'liberties' of the French church, which claimed to fix the boundaries of papal jurisdiction in France. ${ }^{45}$ But it was at least as much an attitude as a codified set of laws, and represented a spirit of independence which resented unrestricted papal monarchy in the day-to-day ecclesiastical government of France. Most famously, however, gallicanism was associated with conciliarism, for in the early fifteenth century France had been a hotbed of the conciliarist doctrine which had been promulgated at the Council of Constance (1415). ${ }^{46}$ When, from 1378, first two and then three rivals had emerged to claim the papal throne in the Great Schism, conciliarism had been presented as the only way to restore peace to a fractured church. The theory received its ultimate formulation in the decrees of Constance which declared that general councils held their authority directly from Christ, and that every one, including the pope, was bound to obey their decrees. Although this decision had subsequently been overturned by a papal bull of 1460 and, for good measure, by the Councils of Florence (1437) and Lateran (1512), the doctrine had not lost its attraction for French churchmen. ${ }^{47}$

The Franco-Tridentine bishops followed in the footsteps of conciliarism's greatest exponent, Jean Gerson, but also in those of later theologians, including Jacques Almain, John Major and Josse Clichtove, who had maintained the doctrine's currency. ${ }^{48}$ Perhaps partly, however, because Gerson was a highly respected writer on pastoral as well as purely theological topics, his treatments of conciliarism proved the most widely disseminated in France during the fifteenth and sixteenth centuries. The enduring popularity of his works ensured that the tradition never lost its prominence within France: six printed editions of Gerson's complete works appeared before 1500, with three more being published during the following century. ${ }^{49} \mathrm{He}$ was most famous for his leadership of the French delegation at Constance, for it was here that he offered the conciliarist doctrine published in February 1417 as the decree Sacrosancta. In his contribution to the Council's outcome, Gerson confirmed that the locus of church unity was the pope under Jesus Christ. Given that conciliarism was a theory formulated to limit papal power, it might seem surprising that Gerson would grant an exalted place to the pope within his doctrine, but he did so as a result of his respect for the pope as the successor of Peter. Yet while Peter's successor possessed a plenitude of power, granted to him by Christ, his use of this power was subject to the authority of a general council and could even be limited if the council deemed this expedient for the edification of the church. ${ }^{50}$ For Gerson, God's will was expressed through the considered determinations of a general 
council, consisting of bishops who were directed by the Holy Spirit: ${ }^{51}$ a general council held supremacy over the pope. Gerson also allowed bishops a large degree of independent authority in their dioceses as well as within the framework of decision-making within the church. Papal authority over bishops was executive, meaning that the pope was obliged to ensure that prelates exercised their jurisdiction according to canonical norms. Otherwise, however, he could not act in dioceses without their consent, for his power over them was not absolute. Episcopal jurisdiction was, therefore, not directly derived from him. Unlike the Council of Trent, the French theologian had no difficulty in confirming that bishops held their jurisdiction according to droit divin..$^{52}$

Cardinal de Lorraine affirmed his faithfulness to this heritage when he commented in 1563 that 'I am French, nourished in the University of Paris, which holds the authority of a council above the pope, and which censured as heretics those who hold the contrary view. ${ }^{53}$ Although he and his fellows were fundamentally in favour of the Council of Trent, ${ }^{54}$ they simply could not stomach the suggestion that the pope's universal authority allowed him to override episcopal jurisdiction, especially since this did not even derive from him. The conciliar theory incorporated and legitimated both of these assumptions: from the belief that the pope did not possess universal jurisdiction within the church, it was logical to assume that he could not interfere in the government of bishops within individual churches and that, therefore, they held their power of jurisdiction directly from God.

It was largely due to the papacy's fear of French support for conciliarist ideas that it so actively encouraged the inclusion of a canon confirming the universality of papal jurisdiction in 1562 and 1563 . Pius IV and his legates even suspected that the French would abandon Trent and in its place hold a national council to resolve the problems of the gallican church and protestantism. After all, the French had, under Louis XII, convoked the infamous Council of Pisa in 1511 which re-issued the decrees of Constance. ${ }^{55}$ Then, in 1551, Henri II had come perilously close to rupturing all relations with the papacy, when Julian III opposed his proposal for a national council to tackle reform. ${ }^{56}$ Judging from past events, comparable initiatives seemed perfectly possible to the sensitive papal circle in the early 1560s. Only recently, the Colloquy of Poissy (1561) had also, in its view, displayed the alarming characteristics of a national council independent of papal control. ${ }^{57}$ At the time of the Colloquy, Pius IV had been horrified by the prospect of it mutating from a meeting to reform the French church into a national council proposing to resolve matters of faith and morals, and appears to have assumed that a gallican council would inevitably mean a wholly independent gallican church. In particular, Pius mistrusted Lorraine's motives and did his utmost to ensure that the papacy could offset any movement along the road to a gallican council by deftly obliging the cardinal, as a newly appointed 
papal legate, to work closely with two other loyal papal legates in the lead-up to the Colloquy. ${ }^{58}$ Within this context, Lorraine and his band of bishops remained, one year later, deeply suspect to Rome.$^{59}$ In fact, Lorraine had never intended to pursue the course of action so feared by the papacy, and indeed had only acquiesced to the proposed Colloquy with the provisions that it did not address reforms of faith and that it took place under legatine direction. His favoured approach had been a meeting of the episcopate, under legatine supervision, which would discuss practical ecclesiastical reforms, neither venturing on to the terrain of doctrine nor admitting equal participation by Huguenots in any deliberations.$^{60}$ But this was irrelevant in the cloud of suspicion that subsequently, for the papacy and its supporters at least, surrounded the cardinal and his entourage at Trent.

It would be a mistake to concentrate exclusively, however, on the tensions dividing French bishops and Rome during the later sixteenth century. To render full justice to the complexity of episcopal attitudes towards the papacy we must also take account of the more pro-papal atmosphere that developed within the French church during the century's final two decades. This was partly due to the efforts of the papacy itself whose nuncios cultivated close contact with members of the French episcopate in order to draw them more closely into Rome's orbit. ${ }^{11}$ Perhaps more importantly, the heavily pro-papal Catholic League played its part in fostering sympathy for the symbol of Catholic unity. Many bishops supported the League during the 1580s and early 1590s: Frederic Baumgartner calculates this number to be fifty-one during the period 1589-91.62 Of course, membership of the League did not necessarily equate with ultramontanism, so that even if a closer relationship existed between the episcopate and the papacy, the bishops still remained anxious to safeguard the traditional prerogatives of their church. In effect, they trod a tightrope between papalism and gallican independence. Most representative of this was the fact that only the League Estates General of 1593 called for the publication of the canons of Trent without qualification. In contrast, the Assemblies of Blois (1576), Melun (1579) and Paris (1586) all requested publication without prejudice to the liberties of the gallican church. ${ }^{63}$

The ultramontane inclination was somewhat uncomfortably reconciled with this gallican perspective. Pierre de Villars, archbishop of Vienne, manifested the wary co-existence between the two attitudes when, in a published volume of his sermons and treatises, he described how he managed to reconcile Trent's decrees with gallican liberties. Painting an idyllic sketch of the ancient church, Villars observed that there had originally been no exceptions to episcopal control in dioceses. ${ }^{64}$ Over the centuries, he continued, the exemptions afforded by traditional gallican liberties had frequently given rise to abuses, disorders and inconveniences. The archbishop squarely attributed 
the blame for the introduction of liberties to those prelates who had misused their authority, so that popes had needed to grant exemptions and privileges to chapters and religious orders in order to protect them. However, now those who held privileges were equally guilty of abuses, leading Villars to urge them to use their rights properly, for the source of heresy lay in 'the cesspit of sin' ${ }^{65}$ Still, he commented, even though Trent had offered an escape from this cycle of abuse by retracting most privileges, he would never 'prejudice' traditional French liberties. For this reason, when he received the Tridentine regulations in his diocesan synod it had been with the protestation that he did not wish to contravene the rights and privileges of the gallican church.

Villars was obviously keen to protect the traditional rights and independence of the French church, but he was concurrently at pains to ensure that the decrees of Trent be officially published so that the French church would no longer be 'almost schismatic'. ${ }^{66}$ His attitude mirrored a pattern then prevailing within the French episcopate. While it arose partly in the inflamed atmosphere of Leaguer politics, bishops perhaps also, consciously or otherwise, turned towards the papacy in the hope that it could provide them with the support that the stumbling monarchy could no longer give. In these threatening circumstances, it made sense to cultivate the goodwill of a powerful ally. That resolution is particularly demonstrated by the language and content of the fourteen reports ad limina sent to Rome between 1587 and 1599. Marc Venard correctly concludes that, in the main, they were written by prelates who sought papal support to combat the material and political suffering caused by the religious conflicts. In his 1593 report, Nicolas de Villars, bishop of Agen, presented himself as a conscientious and active supporter of the League and a reforming bishop carrying through Tridentine policies in his diocese even during bouts of Huguenot belligerence. ${ }^{67}$ Since, as Venard points out, the obligation to present ad limina reports had never had force of ecclesiastical law in France, the actions of these prelates in actually producing and sending them portrays more pro-papal sympathy within the episcopate than before the wars. The heritage of gallican independence was for the moment, therefore, reconciled with a more conciliatory and co-operative attitude towards Rome. Still, there were many bishops who did not join the League, did not cultivate closer relations with Rome and who actually supported the royalist camp throughout the 1580s and 1590s: the strength of the episcopate's 'conversion' to Rome should not be over-estimated. As so often, necessity bred accommodation, but as the immediate threat to life and property receded and political stability returned to France in the seventeenth century, the alliance between bishops and Rome might lose its raison d'être.

Forced to cope with such fundamentally divergent perspectives on droit divin, it is not unexpected to find that the Council of Trent failed to produce a definitive 
definition of orthodoxy on this or on the precise relationship between prelate, pope and priest. The Council's legislation might be described as a theology in elaboration, meaning that it provided basic direction but, by reason of what it omitted, left the way open for further interpretations and possibly, of course, for disagreements. In theory, there seemed every reason why Trent, as a general council of the church, might have presented a complete dogma on these questions but, as so often, the issues which evoked such passionate responses were too intractable for this to be achieved. In any case, the Council's priority was to produce an administrative code that could be immediately put into practice by bishops; the theological underpinning of these rules was partially sacrificed in order to restore momentum to conciliar deliberations. Yet this simply postponed the problems of jurisdiction and droit divin for the future.

A slightly similar result arose in relation to those decrees describing the episcopal pastorate and bishops' spirituality, but for quite different reasons. Any analysis of this legislation is complicated by the fact that successive historians have read its directives rather differently. According to Giuseppe Alberigo, one of Trent's foremost historians, the Council failed utterly to provide a theory of the episcopate, which might have linked spirituality to pastoral work and provided a basis for pastoral action. Indeed, he claims that Trent added no spiritual inspiration whatsoever to the functions of the episcopate: its administrative legislation was composed of traditional and practical principles of reform that were not underpinned by a unitary theological or spiritual vision. ${ }^{68}$ More recently, Oliver Logan has rejected this negative conclusion in his study of the sixteenth-century Venetian clergy. In a very brief discussion of the Tridentine decrees, Logan suggests that Trent did indeed provide what might be called an embryonic pastoral spirituality. Yet he admits that this spirituality was rudimentary, and that it even failed to make full use of traditional pastoral teaching to expose the links between administrative actions and the apostolic vocation of bishops. ${ }^{69}$

Which of these judgements is correct? Certainly, a thorough reading of the legislation on episcopal residency and orders would appear to confirm Alberigo's claim. But is this true of the bulk of its episcopal legislation? In short, the answer is no. Trent did, in fact, occasionally manage to provide guidelines that 'spiritualised' the episcopal office and the duties associated with it. Certainly its legislation on bishops was primarily and principally administrative, for this reflected the Council's immediate objectives. Consequently, any attention that it gave to episcopal spirituality is found in the decrees that described bishops' administrative obligations. But in these decrees the programme of administration is explicitly twinned with a spirituality that was intended to underpin and inspire it. To achieve this, the Council drew on familiar pastoral teachings which emphasised the prelate's role as shepherd, father 
and protector. Even in its otherwise limited decrees on residence, it managed to incorporate the New Testament's analogy of the good shepherd, to underline the fact that bishops could not 'like hirelings . . . desert the flocks committed to them', for only resident bishops could properly 'attend to the guardianship of their sheep'. Prelates should be vigilant in carrying the 'burden formidable even to the shoulders of angels', that of directing souls towards salvation. This metaphor was carried through to the second decree on residence, where bishops were urged to reside as 'shepherds and leaders' of the flock entrusted to them..$^{70}$ Likewise, the bishop's duty to oversee the moral welfare of his charges was based on the image of the benevolent shepherd and father, reproving, entreating and rebuking those under his protection, 'in all kindness and patience'. ${ }^{71}$ Session XXV's decree dealing with the living habits of bishops also attempted to base its call for modesty of table and train upon a pastoral spirituality. Bishops were to 'manifest simplicity, zeal for God and a contempt for vanities' on all occasions. Their temperate example would encourage 'moderation, modesty, continence' and humility in those whom they supervised. Here, the analogy of service was adopted, with bishops presented as 'the servants of the servants of God', those called to labour and care 'for the glory of God' and 'the salvation of souls'. They were to deport themselves so that their lives became 'a sort of perpetual sermon', testaments to God's glory and consistent with the character of their office. ${ }^{72}$

The legislators at Trent were obviously seeking to associate the lives of bishops with their vocational responsibility for the souls in their care: the example and supervision of bishops would lead others towards imitation of their virtues, towards a more Christian life and ultimately, it was implied, towards God. Yet here too, Trent was not truly innovating since its pastoral images of protection, fatherhood, service and guidance were all traditional themes drawn from sources like Saint Paul, Ignatius of Antioch and Gregory the Great. ${ }^{73}$ Indeed, the Council frequently included biblical quotations to support its advice and to connect its bald rules with the conscientious bishop's personal faith. Session VI's precept on residence quoted Paul's advice to Timothy, a classic text on episcopal duties. ${ }^{74}$ But the directives produced were not only traditional; they were also limited in value. Assessed as a whole, Trent's legislation on episcopacy was overwhelmingly legalistic and focused on the disciplinary power of bishops to bring about religious order. It offered only glimpses of the possible theological and spiritual perspectives behind bureaucratic functions. Its decree on preaching, which might have been expected to provide the occasion for references to the pastoral basis of instruction and teaching, did not do so, but merely directed bishops to preach personally and to appoint suitable persons to do so within their dioceses 'for the welfare of the faithful'. There was no reference to the source of bishops' obligations to preach and instruct, that 
is, to the salvation of souls, nor were there any suggestions relating to how a bishop might prepare for this function. It was a similar story in regard to visitations and synods. Bishops were directed to carry these out as key parts of their administration but Trent completely neglected their pastoral motivation and their connection to the vocation of bishops as directors of souls. Nor did the Council dwell on the prelate's personal approach to these duties, in terms of preparation by prayer or reflection on their importance to his pastoral responsibilities. Rather, the decrees simply stated the obligation of prelates to carry out visitations and synods and outlined penalties for their failure to hold synods. What emerged most clearly from the decrees was the fact that a bishop was an administrator. This was Trent's main preoccupation. The spiritual motivation for a bishop's activities was secondary.

Overall, however, Alberigo's evaluation of Trent is rather unjust. Despite its understandable preoccupation with the administrative or legalistic aspects of episcopacy, the Council did offer some spiritual grounding to the pastoral activities of bishops. Prelates were encouraged towards conscientious pastoral administration and care so that they could fulfil their role as protectors and directors of their flocks, ensuring their spiritual welfare and ultimate salvation. The salvation of souls was, therefore, to be the goal of their activities. Yet beyond these stock images of the bishop as shepherd and father, the Council offered little insight into the spiritual foundations of episcopacy or into the virtues which a specifically episcopal spirituality might bring to a bishop's personal life and to his pastorate. In summary, its representations were raw, constrained and unimaginative.

The best indications of Trent's shortcomings on pastoral episcopacy come from the reactions of bishops in its aftermath. Although reasonably happy to adopt its administrative model of visitations, synods and seminaries, these men were far from contented with the guidelines that it had offered on episcopal spirituality and pastoral theology. Almost immediately, they set about amplifying the Council's fledgling material so that it would fulfil the needs of bishops working in the field. Among these ecclesiastics was the archbishop who was quickly to become synonymous with this period of Catholic resurgence, Charles Borromeo of Milan (1538-84). But these were also the decades of prelates like Gabriele Paleotti of Bologna (1522-97), Agostino Valier of Verona (1531-1606) and Jean Ribera of Valencia (d. 1611), all imbued with an energy that fired their administrative and disciplinary reforms. ${ }^{75}$ Another of these bishops, Barthélemy des Martyrs, archbishop of Braga (1514-90), left his diocese only four times in the twenty-one years of his episcopate, if his attendance at Trent is excluded. As a resident bishop, he carried out annual visits of his sprawling diocese with its nearly thirteen hundred parishes, and presided over 
regular diocesan synods. ${ }^{76}$ Each of these bishops based his governing activities on the Tridentine model, giving primacy to residency, visitations and synods. The administrative systems that they implemented in order to overhaul religious discipline among clergy and laity therefore shared sufficient similarities to be labelled as both 'Tridentine' and 'reforming'.

When compared with their reforming brethren in Italy and Spain, French bishops are revealed to have been a good deal slower to adopt Trent's administrative programme. Their delegation returned from Trent reasonably satisfied with its decrees, which at least offered a way forward for reform of the church to be commenced. ${ }^{77}$ Yet, once they stepped back on to their home soil, it appears as if the bishops promptly forgot about the Council's objectives for several years. Of course, intermittent conflicts could discourage even the most enthusiastic bishop from instituting reforms. Still, the bishops did manage to hold diocesan synods on their return, and here they might have referred to Trent's regulations. Rather surprisingly, however, their statutes, with just one exception, do not mention Trent at all. ${ }^{78}$ But within two decades Trent was mentioned in the resolutions of virtually every synod, and reform-minded bishops increasingly adopted its programme.

Several reasons lay behind this shift: in the first place, although the wars may initially have discouraged or prevented some prelates from undertaking reform, the decrees were gradually recognised to be the best weapons with which to trounce protestantism. This was particularly the case in the wake of the obvious failure by 1567 of the crown's policy of religious toleration. ${ }^{79}$ Enthusiasm for the Tridentine programme was a gradual and rational decision on the part of those French bishops who recognised the need for ecclesiastical reform and who were actively willing to foster it. It may also have been a product of the strategic warming of relations between bishops and Rome during these years of critical political insecurity. At least as important, however, is the fact that several French bishops were genuinely inspired and influenced by the efforts of dynamic prelates elsewhere who had successfully initiated Tridentine-style administrative reforms in their dioceses. Although these stimulations to reform did not affect the whole episcopate, they did energise individuals who can certainly not be simply distinguished from their brethren as ultramontanes: they included some who were quite anti-papal and anti-Leaguer in their politics, while pro-Tridentine in their ecclesiastical outlook. One did not need to be an ultramontane to favour Tridentine reform. Cardinal de Joyeuse was a determined supporter of Henri IV, but an equally avid advocate of Trent's rules and an ardent admirer of its standard-bearer, Charles Borromeo. ${ }^{80}$

This cautious reinvigoration was facilitated and reflected, in part, by the availability of the Council of Trent's decrees, published in French for the first time in 1564 and reprinted at least ten times before $1600 .{ }^{81}$ But active reform 
initiatives were most clearly apparent in the cluster of provincial councils held from the early 1580s. These were heavily Tridentine in tone, in the sense that they officially received the Council's decrees within their provinces and incorporated the Tridentine legislation into their own statutes. ${ }^{82}$ Significantly, they were also substantially influenced by the post-conciliar legislation produced by Charles Borromeo for the reform of the archdiocese of Milan. Both Paul Broutin and Henri Brémond assumed that the papal enclave of Avignon acted as the conduit for the popularisation of Trent and Borromeo in France: under the government of several reforming bishops from Rome, such as Philip Neri's companion Francesco Tarugi, it saw synods and visitations from 1566 onwards and acted as a kind of shop window for Catholic reform. In contrast, Marc Venard's magisterial study of Avignon has pointed out that the progress of rejuvenation in the province coincided with, rather than anticipated, the early pulse of reform in France. ${ }^{83}$ His conclusion suggests that one must seek beyond Avignon to find the channels responsible for the dissemination of the Tridentine and Milanese disciplines.

The connections between reform-minded French bishops and Borromeo proliferated during the late sixteenth century, so that the growing cult around the Milanese archbishop gradually filtered into the French church. It is not unexpected that French bishops should have been attracted to the practical and thorough detail of Borromeo's regulations, seemingly perfectly adoptable in any diocese and responsive to the most entrenched forms of disorganisation. The breadth of these contacts should not be over-estimated, but it is possible to point to some bishops who definitely benefited from their acquaintance with Borromeo or Borromean admirers and imitators. At least one French archbishop, Pierre de Villars, esteemed by the bishop of Geneva, François de Sales (1567-1622), for his conscientious episcopate, enjoyed a limited correspondence with the Milanese archbishop and venerated his memory. ${ }^{84} \mathrm{He}$ visited Borromeo's tomb in May 1592 as he returned from a sojourn in Rome ${ }^{85}$ Borromeo himself was not actually in personal contact with many French bishops, even though subsequent tradition reported that François de La Rochefoucauld met him in $1579 .{ }^{86}$ It was principally through his disciples, and one of his successors in Milan, Federico Borromeo (1564-1631), that the archbishop's distinctive reform methods became known in France and that his cult was promoted. Nuncios Castelli (term in office 1581-83) and Ragazzoni (term in office 1583-86) and the Tuscan archbishop of Aix-en-Provence, Alexandre Canigiani, were all close disciples of Borromeo and did their best to encourage bishops to adopt his methods of government. ${ }^{87}$ Ragazzoni, a former reforming bishop of Bergamo, enjoyed continuous relations with François de Joyeuse, archbishop of Narbonne, Cardinal de Bourbon of Reims and Bishops Rose of Senlis and Gondi of Paris, all of whom had an interest in ecclesiastical reform. ${ }^{88}$ 
Federico Borromeo, nephew of Charles and his successor in Milan, was a close advisor of the future cardinal and Borromean devotee François de Sourdis from the 1590s, while François de Sales knew a number of French prelates such as La Rochefoucauld, Pierre de Villars and, slightly later, Jean-Pierre Camus. ${ }^{89}$ These were bishops who adopted the Borromean-Tridentine style of administration in their own activities and acted as channels for its broader dissemination within the French church.

That the dominant influence on administrative reform within the French episcopate during the late sixteenth century was Charles Borromeo is again obvious from the legislation of the seven provincial councils held in France during these decades. All these borrowed heavily from the decrees of Borromeo's provincial councils, which were collectively published in 1582 as the Acta ecclesiae Mediolanensis. As templates for navigating disciplinary reform, these decrees were highly attractive to bishops, for they ranged logically over virtually every conceivable area of administration, from ecclesiastical conferences to confraternities. When the papal nuncio Anselmo Dandino addressed the Assembly of Clergy at Melun in 1579, he took the opportunity to propose that Borromeo's texts be used as a basis for its legislation. ${ }^{90}$ This suggestion met with the Assembly's approval, and Melun successively provided the model for the seven provincial councils held between 1581 and $1590 .{ }^{91}$ In fact, these were, if anything, even more Borromean in structure and tone, confirming the burgeoning of this tradition in France and the late archbishop's influence on episcopal reform.

Melun voiced its support for the promulgation of the Tridentine decrees in France (though with the proviso that gallican liberties be preserved), but drew substantially on the 1566 council of Milan, even following its order of topics, for its detailed recommendations to bishops. Like other late sixteenthcentury French councils, it insisted that bishops be resident and conduct their administrative duties with care. ${ }^{92}$ Recognising the urgent need for residency, the Council of Bourges even went as far as to order prayers to be recited for this end. These synods structured episcopal administration around diocesan visitations and synods, asking that they be held regularly to assist the supervision of clergy and ecclesiastical government: 'Among the charges of bishops one of the principal . . . is the visitation, of which the first goal must be to introduce and maintain sound and correct doctrine . . ; to support and preserve good morals. . ., to move and enflame people to true religion by exhortations and remonstrances, and to ordain all things for the edification of the faithful. ${ }^{93}$ After Melun, each council confirmed its acceptance of the decrees of Trent, but included specifically Borromean innovations in its administrative directions to bishops. Embrun, for example, advised its bishops to divide their dioceses into congregations, with vicars forane overseeing monthly conferences of parish priests for the purpose of study, prayer and the celebration of the mass. ${ }^{94}$ 
The very fact that French bishops held these councils during the late sixteenth century demonstrates that ideas of reform were filtering fitfully into France: provincial councils had been advocated by Trent as essential to ecclesiastical renewal. Moreover, their prevalence indicates that several members of the episcopate were not simply interested in purely theoretical concepts of reform but were actively attempting to achieve it, and realised the crucial administrative role of bishops in doing so. Of course, adopting Tridentine and Borromean governmental practices within councils was of no use unless efforts were made by bishops to follow these directives in their dioceses. The evidence suggests that some bishops, though again a minority, sought to do just that; a number of visitations were carried out and several bishops held diocesan synods at which Trent's decrees were promulgated..$^{95}$ Pierre de Villars was actively committed to the programme of Tridentine reform. Visitations, synods and personal preaching, virtually unknown by bishops throughout most of the century, were principal elements of his episcopate as a result. ${ }^{96}$ Villars's interest in reform and his efforts to implement it were also manifested in the subjects of his Opuscules; he composed these didactic exhortations to his clergy in the hope of relighting 'the blaze of devotion'. Topics that Villars considered important enough to discuss included the perils of simony and confidence, the importance of clerical residence and the interior dispositions and external behaviour necessary to ecclesiastics. ${ }^{97}$

Villars also noted in his Opuscules that several prelates resided in their dioceses and were active administrators. They were, therefore, he noted with a hint of flamboyance and probably of hyperbole, 'torches of doctrine, blazes of piety and devotion'. 98 'Several' resident bishops does not seem a large number when the episcopate numbered over 100 prelates, but Villars was surely referring only to the province of Vienne, which had eight dioceses. From Mirepoix in the province of Toulouse, Pierre de Donnaud reported in 1593 that he had carried out visitations, convoked a synod, and established laws 'conformed to the sacred canons, and especially to the holy Council of Trent' ${ }^{99}$ Cardinal de Joyeuse, it appears, also attempted to put into practice the administrative directions contained in the provincial council over which he presided in 1581 . His report to Rome nine years later claimed that he had held a provincial council, several diocesan synods and visitations 'in conformity to the prescriptions and examples of the Council of Trent' ${ }^{100}$ Indeed, it appears that his visits owed just as much to Borromeo's example, for they rigorously followed the format developed by the archbishop of Milan, and included questionnaires and inventories for curés to complete and procès-verbaux of the visitations' proceedings, as well as post-visit deliberations and archiepiscopal statutes that were devised using the results of the visitations' investigations. ${ }^{101}$

Administration was just one aspect of episcopacy, however, albeit a crucial one. Post-Tridentine bishops both outside and inside France were well 
aware of this fact. Many of them came to realise that the Council of Trent did not offer a comprehensive treatment of episcopacy in all its facets. Feeling insufficiently served by Trent, they themselves, therefore, had to supplement its shortcomings. For this reason, a number of works on the officium episcopi were published during the late sixteenth century, envisaged as guidebooks for bishops on the spiritual and practical aspects of their office. The driving forces behind these were, not surprisingly, prelates themselves. A number of them actually produced texts based on their own practical experiences and reflections and, in particular, attempted to provide an episcopal spirituality to inspire and supplement administrative actions. One such was the well-known reforming archbishop of Braga, Barthélemy des Martyrs, whose Stimulus pastorum proved a highly popular manual among bishops. Although this was initially written by Martyrs as a handbook for his own use, its potential appeal to other bishops was recognised by his associate, Louis de Grenade, who published the book in 1564. The Stimulus subsequently went through numerous editions, and Borromeo himself thought it an extremely useful guide for bishops. ${ }^{102}$ It reached France too, for it was printed four times in Paris during the 1580s. ${ }^{103}$ The particular value of the work lay in the fact that its author fused Trent's practical directives with an intense, interior spirituality in order to provide a link between administration and theology. The motives for a bishop's actions, he claimed, were unreserved love for God and affection for the souls under his care. These were the twin guides for tireless administration and could be cultivated through prayer, meditation and daily eucharistic celebration. They would then manifest themselves in the exterior actions of conscientious administration and in personal virtue. Spirituality had, therefore, to accompany and inform administrative practice; without this fusion, the bishop's activities were simply formulaic. A real episcopal pastorate would see the prelate acting 'like a sun which shines forth to light the earth', as an administrator but, equally, as a director of souls. ${ }^{104}$

Another work of this genre, Agostino Valier's Discours en manière d'instruction, was translated into French in $1585 .{ }^{105}$ Similar in structure and themes to that of Martyrs, Valier's work was the product of his extensive experience as bishop of Verona. It too emphasised the administrative duties of bishops within their overall character as pastors and ambassadors of Christ, entrusted with the salvation of souls. For Valier, every chore of episcopal government could be related to its ultimate divine purpose, and bishops could prepare themselves for their duties through prayer and study. At least some French bishops valued this kind of guidance: an inventory of the personal library of the bishop of Cahors, Antoine IV Ebrard de Saint Sulpice, recorded that he possessed a copy of Valier's Discours, along with French and Latin editions of the Council of Trent and the Acta ecclesiae Mediolanensis. ${ }^{106}$ The French translation of Valier's work on 
the officium episcopi was actually completed by Ebrard's archdeacon and relative Chrétien d'Ebrard de Saint Sulpice, who reported in its preface that the bishop of Cahors had brought an Italian copy of the book to France from Italy.

Louis de Grenade (1504-88), the Spaniard behind the publication of Martyrs's work, was one of the key figures writing on episcopacy during the post-Trent years. Rather than a bishop, Grenade was the provincial of the Portuguese Dominicans, but his reform initiatives ranged widely from preaching to the publication of spiritual and theological writings. ${ }^{107}$ His interest in episcopally driven reform led him to publish a volume on the topic of episcopacy just one year after the Stimulus was first printed. In it, he explored many of the ideas contained within the Stimulus, once again seeking to provide a synthesis between the theology and spirituality of episcopacy and its practical functions of administrative government. The dignity of the office, Grenade noted, was such that only the truly worthy should be promoted to it, those who were able and willing to live holy lives and who possessed the virtues of prudence, diligence, fortitude and knowledge. ${ }^{108}$ Drawing on his own extensive experience as a preacher, Grenade also produced a work on preaching entitled Ecclesiasticae rhetoricae, at the request of Charles Borromeo. The archbishop of Milan was also the driving force behind Valier's De rhetorica ecclesiastica and Diego de Estella's Modo de predicar, works specifically designed to advise bishops on effective preaching. ${ }^{109}$ Setting an example for his fellow bishops, Borromeo preached personally and invited skilled preachers, including Francesco Panigarola, to Milan. ${ }^{110} \mathrm{He}$ is, therefore, particularly significant in the history of late sixteenth-century episcopalism for three reasons: for his distinctive administrative discipline, based on the Council of Trent; for his emergence as an episcopal model even within his lifetime; and for his promotion of writing and reflection designed particularly to aid bishops and to build on the limited principles of Trent.

Evidently, reforming bishops of the late sixteenth century were struggling to establish a vision of episcopacy that covered all aspects of their pastorate. It was as pastors that Borromeo, Martyrs and the bishops who imitated them, like Ribera of Valencia, ${ }^{111}$ primarily understood their role, and they searched for an ideology which situated administrative functions within a theological and spiritual framework that was broader and less legalistic than that offered by Trent. Their views made their way into France through the publications described above but were also incorporated into the acts of Charles Borromeo's provincial councils. As a result, the provincial councils held in France during the 1580s and 1590s used the language of Borromeo and, therefore, of those non-French bishops who, like Ribera, were influenced by him, as well as of Martyrs who shared so closely the views of Borromeo on episcopal spirituality. Melun stressed the episcopal virtues of piety, humility and wisdom as well as the obligation of bishops to cultivate these through frequent recourse to 
prayer, confession and the eucharist. They were also, as Trent had directed and reforming bishops had exemplified, to live as simply and modestly as possible. ${ }^{12}$ Great emphasis was simultaneously placed on episcopal preaching, in the wake of Trent's admonition and the efforts of reforming bishops to encourage this practice. ${ }^{113}$ The bishop had to combine diligent administration of his diocese with a strong spiritual life, concerning himself solely, therefore, with the health of souls and 'celestial habitation'. All his actions and indeed his entire outlook were to be governed and inspired by these goals. ${ }^{114}$

The hagiographic tradition that developed around Charles Borromeo was yet another means of propagating contemporary ideas. Slightly surprisingly, given his popularity, no French editions of the archbishop's life were produced at this stage, but a general hagiographic cult was already well on its way: Agostino Valier's life of Borromeo, first published in 1586, went through a dozen editions up to 1604 while another enthusiast, Carlo Bascapé, produced a further hagiographic work in 1592. ${ }^{115}$ Each concentrated on the rigorous administrative style adopted by Borromeo and on his concern for discipline within his diocese. Yet they also attended to the archbishop's spiritual life, describing his constant efforts to deepen his relationship with God through prayer, study and the sacraments. The result, as they judged it, was that he not only carefully fulfilled his administrative responsibilities but he did so with great virtue and with the sole motive of serving God.

Much of what Borromeo, Martyrs and Valier included in their writings and adopted as guiding principles for their pastoral ministries was already familiar fare within the older tradition of writing on episcopacy. Certainly there was no shortage of raw materials for this, particularly from the early church and its leading figures, many of whom were themselves prelates; Martyrs's Stimulus pastorum made frequent reference to the patristic literature of Augustine and John of Chrysostom, for example, incorporating their advice into his personal vision of the bonus pastor. These were also among the Fathers of the church counted by Valier as suitable role models for episcopal preaching. ${ }^{116}$ It is true, too, that some effort to provide a specifically episcopal theology and spirituality had been made within the church by more recent, but still pre-Trent theologians. The same French sources that had so much advice to offer bishops about administration also recommended ways in which they could develop their spiritual life and their relationship with God in a manner appropriate to those charged with the care of souls. To this end, they described the bishop's vocation in terms of obligation. His task was to guide souls to salvation through both word and deed. He should, therefore, be a disciple of Jesus Christ, with qualities of integrity, wisdom, eloquence, humility and courage. Using, as Trent would subsequently, the particularly pastoral images of the shepherd and his flock and the benevolent father caring for his children, 
reformers urged bishops to nourish their charges through teaching and example, and stressed that they should be prepared to devote their entire lives to their spiritual benefit. ${ }^{117}$ This attempt to provide government and administration with a clear spiritual motivation was accompanied by directions on how a prelate could develop a profound sense of vocation and a close relationship with God. To achieve both, preachers and theologians advised regular prayer as well as study of the life of Jesus Christ. Jean Gerson's advice to Pierre d'Ailly when he acceded to the bishopric of Le Puy in 1395 detailed specific reading through which the bishop could hope to find spiritual nourishment and strength for the particular functions of his office. Spiritual reading and study was a theme of special importance to Gerson; he referred five times to its necessity in the course of his letter to the new bishop of Le Puy. He particularly recommended the pastoral works of revered bishops like Gregory the Great, Gratian and Ambrose as well as the lives of the ancient bishops. The inexperienced prelate should also, he stated, study the Gospels and Paul's epistles so that he might gain spiritual insight into the episcopal condition and its attendant responsibilities. ${ }^{118}$

These theologians and preachers hoped to encourage what they considered to be currently missing from the lives of many prelates caught up in worldly pursuits: a sense of true vocation, grounded in a deep conviction that they served God and that they were pastors of souls. In this model, the bishops' administrative functions would not be merely means of governing, but would have a real spiritual resonance. Bishops would not, therefore, be just administrators, like secular officials, but representatives of Christ who, modelling themselves on Jesus and saintly prelates, were actively engaged in the work of salvation. ${ }^{119}$ Yet there is no doubt that bishops of the late sixteenth century found this representation inadequate. Although not wholly neglecting theology, reformers in France, like those at Trent, were preoccupied with establishing systematic administrative practice. The theology and spirituality of episcopacy were always secondary to their primary concern for immediate and visible reform. In consequence, bishops like Borromeo, Martyrs and Valier believed themselves obliged to supplement the existing advice with the ideas most valuable to their own experiences and requirements. The same conviction was obviously held by French bishops who adopted Borromean-Tridentine reforms and who provided the readership for the new literature dealing with the episcopal condition. It was not that the pre-existing teachings on episcopacy were outdated. Rather, it was felt that contemporary interpretations of the office were necessary. These, by expanding on traditional ideas and incorporating original and energetic insights, would be more directly relevant to bishops and sensitive to their immediate circumstances.

In many ways, the views expressed in both word and deed by bishops like Borromeo were absolutely in tune with those of pre-Tridentine reformers. 
The main difference between the post- and pre-Trent eras was that the period after the Council saw a number of dedicated bishops, imbued with the spirit of reform, putting these ideas into practice and encouraging others to do so. Yet, despite their hopes, these bishops did not really succeed in escaping from the bureaucratic or legalistic straitjacket fashioned by the Council. French bishops admired the personal virtues and the spiritual ideas which drove Borromeo's episcopal activities, just as they admired the example of Barthélemy des Martyrs and other reforming bishops. Yet it was principally their administrative energy and strategies which had caught the imagination of this minority of French prelates; there is no evidence that these men had latched on to any mature pastoral model of episcopacy. Their narrow interpretation of the office was a function of the fact that, generally, the post-Tridentine vision of the good bishop remained heavily dependent on the bishop as administrator, with only limited efforts to develop the theological aspects of the office. Attempts were being made to forge an episcopal spirituality for contemporary bishops, but there were several directions in which this development could move, depending on the needs of prelates. This was especially true in the case of French bishops who lacked contemporary models of their own to follow and depended largely, for the moment, on the ideas of non-French reformers.

By the turn of the sixteenth century, therefore, French prelates had a variety of sources on which to base their understanding of the episcopal office. Those guides most immediately to hand, Trent and the examples of contemporary reforming prelates, appeared particularly attractive, for they enabled the minority of French bishops who were attempting to introduce reforms in insecure conditions to lay the foundations for permanent ecclesiastical order. At the same time, a strong native tradition of reflection on episcopacy existed which had influenced the stance of Trent's French delegates and which could conceivably do so among future generations of bishops. This French tradition provided strongly articulated views on episcopal jurisdictional rights and authority as well as, secondarily, on episcopal spirituality. Ultimately, however, the body of representations on episcopacy that swirled within the Catholic church was as noteworthy for its shortcomings, ambiguities and outright contradictions as for its mature ideals. If French bishops sought jurisdictional, spiritual, theological or pastoral models of episcopacy, they would find fundamentals in Tridentine prelacy, the Borromean example and the French ecclesiastical tradition. Yet there was certainly no necessary accommodation between any of these, and none of them offered a thoroughly rounded episcopal ideal.

Notes

1 A standard biography of Lorraine is Henry Outram Evennett's The Cardinal of Lorraine and the Council of Trent (Cambridge 1930).

2 John McManners, Church and Society in Eighteenth-Century France, 2 vols (Oxford 1998), i, p. 2. 
3 See Daniel Cuisiat's brief assessment of a historiographical tradition, originating in contemporary Huguenot condemnations of Lorraine's political strategies and career, which has, with few exceptions, 'judged and condemned' the cardinal 'without appeal': Charles de Lorraine, Lettres du cardinal Charles de Lorraine (1525-1574), ed. Daniel Cuisiat (Geneva 1998), pp. 12-13.

4 Frederic Baumgartner, Change and Continuity in the French Episcopate. The Bishops and the Wars of Religion 1547-1610 (Durham, North Carolina 1986), pp. 134-8. See also Baumgartner's 'Renaud de Beaune, Politique Prelate', Sixteenth-Century Journal, 9 (1978), 99-114, which (correctly) describes de Beaune as 'an ambitious politician and royalist, whose attitude toward his religion was less a concern for the impact of his actions on the church than for how they affected his career and the monarchy'.

5 Procès-verbaux, i, p. 127.

6 Bergin, Episcopate, p. 340.

7 Montauban and Pamiers: Cinq visites ad limina, ed. J. Contrasty (Paris 1913), pp. 41-2.

8 Bergin, Episcopate, pp. 338-9.

9 Baumgartner, Change, pp. 133-4.

10 Quoted in Marc Venard, 'Ultramontane or Gallican? The French Episcopate at the End of the Sixteenth Century', The Jurist, 52 (1992), 158-61.

11 Baumgartner, Change, p. 12; Bergin, Episcopate, pp. 32, 48-52.

12 Bergin, Episcopate, p. 342.

13 It was de Beaune who lifted the papal excommunication from the newly converted Henri in 1593: Baumgartner, 'Renaud de Beaune', 108-11.

14 Bergin, Episcopate, p. 376; Marc Venard, 'Henri IV et la réforme catholique', Henri IV le roi et la reconstruction du royaume. Actes du $3^{\circ}$ Colloque Pau-Nérac, 14-17 septembre 1989 (Pau 1990), pp. 301-15.

15 Mark Greengrass, 'Aristocracy and Episcopacy at the End of the Wars of Religion in France. The Duke of Montmorency and the Bishoprics of Languedoc', in Vogler (ed.), Miscellanea, pp. 356-63; Nicole Lemaître, Le Rouergue flamboyant. Le clergé et les fidèles du diocèse de Rodez 1417-1563 (Paris 1988), p. 223.

16 Bergin, Episcopate, pp. 632-3.

17 Ibid., pp. 616, 704-5.

18 Ibid., pp. 715-16.

19 The practice whereby one person held a benefice in trust for another.

20 The total of 130 bishops refers to those whose social origins are known: Hayden, 'Origins', 32.

21 Bergin, Episcopate, pp. 354-8.

22 Lemaître, Rouergue, pp. 217-392; Jean-Pierre Massaut, Josse Clichtove, l'humanisme et la réforme du clergé, 2 vols (Paris 1968), ii, pp. 13-14; Larissa Taylor, Soldiers of Christ (New York 1992); Michel Veissière, 'Guillaume Briçonnet, évêque de Meaux, et la réforme de son clergé', Revue d'histoire ecclésiastique, 84 (1989), 655-72.

23 Jean Delumeau, Catholicism between Luther and Voltaire, trans. Jeremy Moiser (London and Philadelphia 1977), pp. 16-19; Evennett, Spirit, pp. 89-107.

24 Canons and Decrees of the Council of Trent, ed. H. J. Schroeder (Saint Louis and London 1941), Sess. VI, ch. I, pp. 47-8.

25 Ibid., Sess. XXIV, chs II and III, pp. 192-3.

26 Most recently, the Council of Basel (1433): Decrees of the Ecumenical Councils, ed. Norman P. Tanner, 2 vols (London and Georgetown 1990), p. 473.

271560 was a year of perilous political crisis for the monarchy. Following the sudden death of Henri II in July 1559, March 1560 saw the Huguenot conspiracy of Amboise, followed, in December, by the premature death of François II and the regency of Catherine de Medici: Nicola Sutherland, The Huguenot Struggle for Recognition (New Haven and London 1980), pp. 62-100; Alain Tallon, La France et le Concile de Trente (1518-1563) (Rome 1997), p. 301. For a contrary but unconvincing assessment of the Colloquy as a truly ecumenically driven 
assembly, see Donald Nugent, Ecumenism in the Age of the Reformation. The Colloquy of Poissy (Cambridge, Massachusetts 1974), pp. 37-67, 204-19.

28 Tallon, Trente, pp. 301-4.

29 Ibid., p. 713.

30 Massaut, Clichtove, ii, pp. 47-57; M. Piton, 'L'Idéal épiscopal selon les prédicateurs français de la fin du xv et du début de xvi siècle', Revue d'Histoire Ecclésiastique, 61 (1966), 77-118, 393-423.

31 Taylor, Soldiers, pp. 238-41; Larissa Taylor, Heresy and Orthodoxy in Sixteenth-Century Paris. François Le Picart and the Beginnings of the Catholic Reformation (Leiden, Boston and Cologne 1999).

32 Taylor, Soldiers, pp. 37-51.

33 E. Vansteenberghe, 'Un programme d'action épiscopale au début du xv siècle (lettre inédite de Jean Gerson)', Revue des Sciences Religieuses, 19 (1939), 26, 29.

34 Piton, 'L'Idéal', 93; Taylor, Soldiers, p. 98.

35 Massaut, Clichtove, ii, p. 52; Louis Pascoe, Jean Gerson. Principles of Church Reform (Leiden 1973), pp. 138-45; Piton, 'L'Idéal', 408-9; Vansteenberghe, 'Programme', 27-8.

36 Jedin, History, ii, pp. 317-69; Canons, ed. Schroeder, Sess. VI, ch. I, pp. 47-8.

37 Jedin, History, ii, p. 356.

38 Hubert Jedin, Crisis and Closure of the Council of Trent 1562-1563 (London 1967).

39 Tallon, Trente, pp. 370-1.

40 Ibid., pp. 771-2, 778-84.

41 Canons, ed. Schroeder, Sess. XXIII, pp. 160-79; E. Boularand, 'Le Sacerdoce de la loi nouvelle d'après le décret du Concile de Trente sur le sacrement de l'ordre', Bulletin de Littérature Ecclésiastique (1955), 193-228.

42 Canons, ed. Schroeder, Sess. XXIII, p. 162; André Duval, Des sacrements au Concile de Trente (Paris 1985) p. 328; J. Pégon, 'Episcopat et hiérarchie au Concile de Trente', Nouvelle Revue Théologique, 82 (1960), 581. The Council did not actually use the term 'charism', but this traditional concept underpinned its decree. In Christian theology, 'charism' or 'charisma' refers to a special divine favour (a grace) that is given to Christians, through the power of the Holy Spirit, to perform their specific tasks in the church (it is not a grace given for personal perfection). According to Trent, therefore, special 'structural' charisms of the episcopal office included apostolic authority and ministry, through which the bishop possessed the power to govern, ordain and confirm: New Catholic Encyclopedia, 18 vols (New York 1967-2001), iii, pp. 460-2.

43 Aquinas became a doctor of the church in 1567: Anthony Wright, The Early Modern Papacy. From the Council of Trent to the French Revolution 1564-1789 (Harlow 2000), p. 94.

44 The episcopal powers of perfection were those of confirmation and ordination, by which the bishop drew others towards perfection of faith and salvation: Joseph Lécuyer, 'Les Etapes de l'enseignement thomiste sur l'épiscopat', Revue Thomiste, 57 (1957), 29-52.

45 See Victor Martin, Les Origines du gallicanisme (Paris 1939), for the medieval background to seventeenth-century disputes.

46 Decrees of the Ecumenical Councils, ed. Norman P. Tanner, 2 vols (London and Georgetown 1990), i, pp. 409-10, 532-4, 595-6; Aimé-Georges Martimort, Le Gallicanisme de Bossuet (Paris 1953), p. 47; Walter Ullmann, Medieval Political Thought (Harmondsworth 1975), pp. 219-22.

47 Decrees, ed. Tanner, i, pp. 532-4, 595-6; Martimort, Bossuet, p. 47; Phillip Stump, The Reforms of the Council of Constance (1414-1418) (Leiden, New York and Cologne 1994), pp. $104-9$.

48 Francis Oakley, 'Almain and Major: Conciliar Theory on the Eve of the Reformation', American Historical Review, 70 (1964-5), 674-90, and his 'Conciliarism in the Sixteenth Century: Jacques Almain Again', Archiv für Reformationsgeschichte, 68 (1977), 111-32. On Clichtove, see Massaut, Clichtove, ii, p. 66. For conciliar theory prior to 1378, see Brian Tierney, Foundations of the Conciliar Theory. The Contribution of the Medieval Canonists from Gratian to the Great Schism (Leiden, New York and Cologne, 1998). 
49 D. Catherine Brown, Pastor and Laity in the Theology of Jean Gerson (Cambridge 1987), p. 2.

50 Ibid., p. 43; B. J. Caiger, 'Doctrine and Discipline in the Church of Jean Gerson', JEH, 41 (1990), 389-407.

51 Pascoe, Gerson, p. 47.

52 Brown, Gerson, p. 75.

53 Instructions et lettres des rois tres-chrestiens et de leurs ambassadeurs et autres actes concernant le Concile de Trente pris sur les originaux (Paris 1654), p. 556: 'Je suis François, nourry en l'université de Paris, en laquelle on tient l'authorité du concile par-dessus le pape, et sont censurez comme hérétiques ceux qui tiennent le contraire.'

54 Tallon, Trente, pp. 303, 453.

55 This was primarily a political council, designed to avenge Julius II's alliance with French enemies by extending the military offensive into the ecclesiastical sphere, but the principle of conciliarism informed French strategy: Oakley, 'Almain', 674.

56 The Council was proposed in response to the growth of Calvinism in France and would, Henri anticipated, introduce reforms to counteract it: Marc Venard, 'Une réforme gallicane? Le projet de concile national de 1551', Revue d'Histoire de l'Eglise de France, 67 (1981), 201-8.

57 Tallon, Trente, pp. 302-3, 305.

58 Evennett, Lorraine, pp. 102-12; Nicola Sutherland, Princes, Politics and Religion 1547-1589 (London 1984), pp. 121-2.

59 BN, Ms. Dupuy 357, fo. 186; Lorraine, Lettres, p. 468, Lorraine to Charles IX, 27 November 1562 .

60 Sutherland, Princes, pp. 124-37.

61 Venard, 'Influence', p. 210; Venard, 'Ultramontane', 150-2.

62 Baumgartner, Change, p. 166; Frederic Baumgartner, 'Crisis in the French Episcopacy. The Bishops and the Succession of Henry IV', Archiv für Reformationsgeschichte, 70 (1979), 278-97.

63 Victor Martin, Le Gallicanisme et la réforme catholique (Paris 1919), pp. 136, 148, 261. In fact, the decrees were never adopted officially under French law.

64 Pierre de Villars, Opuscules et divers traictez, sur plusieurs sujects et matières ecclésiastiques. Même des principaux, et plus nécessaires articles de réformation, ordonnez ar le sainct Concile de Trente, 2 vols (Lyons 1598), ii, p. 489.

65 Ibid., pp. 501, 506.

66 Ibid., p. 497.

67 Ibid., pp. 159-60.

68 Alberigo, 'L'episcopato'.

69 Logan, Venetian Clergy, p. 23.

70 Canons, ed. Schroeder, Sess. VI, ch. I, p. 47, and Sess. XXIII, ch. I, p. 164.

71 Ibid., Sess. XIII, ch. I, p. 81.

72 Ibid., Sess. II, ch. I, p. 13, and Sess. XXV, ch. I, pp. 232-3.

73 The Ignatian letters are available in J. B. Lightfoot, The Apostolic Fathers, 2 vols (London 1885), i. Gregory's Pastoral Rule is printed in A Select Library of Nicene and post-Nicene Fathers of the Christian Church, trans. Charles Lett Feltoe, 12 vols (Oxford and New York 1895), xii, pp. 9-71.

74 Canons, ed. Schroeder, Sess. VI, ch. I, p. 47; 2 Tim. 4:5.

75 Logan, Venetian Clergy, pp. 215-374; Prodi, Paleotti; John B. Tomaro, 'San Carlo Borromeo and the Implementation of the Council of Trent', in Headley and Tomaro (eds), Borromeo, pp. 67-84; Anthony Wright, 'The Borromean Ideal and the Spanish Church', ibid., pp. 188-208; Anthony Wright, 'San Juan de Ribera and Saint Charles Borromeo. The CounterReformation in Spain and Italy Compared', in Vogler (ed.), Miscellanea, pp. 364-72. See also the study of Bollani of Brescia: Cairns, Domenico Bollani, pp. 149-200.

76 Almeida Rolo, L'Evêque, pp. 107, 133.

77 Tallon, Trente, pp. 805-7. 
78 Venard, 'Ultramontane', 147-8. Cardinal de Lorraine's 1564 provincial council for Reims affirmed the Tridentine doctrines in its profession of faith.

79 Sutherland, Struggle, pp. 137-77; Tallon, Trente, p. 816.

80 Venard, 'Ultramontaine', 157-8.

81 Gentian Hervet, Le Sainct, Sacré et général concile de Trente (Reims 1564).

82 Venard, 'Ultramontane', 152-3; Marc Venard, 'Un concile provincial oublié. Le Concile d'Embrun en 1583', Provence Historique (1992), 628.

83 Marc Venard, Réforme protestante, réforme catholique dans la province d'Avignon xvi siècle (Paris 1993), pp. 616-28, 1095-7.

84 François de Sales, Oeuvres complètes de Saint François de Sales, 27 vols (Annecy 1892-1964), xiv, p. 128, de Sales to Villars, 15 February 1609.

85 H. de Terrebasse, Pierre de Villars archévêque et comte de Vienne 1545-1613 (Lyons 1897), pp. 8-16.

86 Venard, 'Influence', 210, but see Bergin's comments in La Rochefoucauld, p. 14.

87 Venard, Réforme, pp. 733, 1100.

88 Venard, 'Influence', p. 208; Venard, 'Ultramontane', 152.

89 Sales, Oeuvres complètes, xii-xix; Peyrous, Réforme, i, pp. 120-4; Kleinman, De Sales, pp. 44-5.

90 Venard, 'Ultramontane', 152.

91 Rouen (1581), Bordeaux (1583: Venard dates this council 1583, though in Concilia novissima Galliae, ed. Ludovicus Odespun de La Méchinière (Paris 1646), p. 279, it is dated 1582), Tours (1583), Embrun (1583), Bourges (1584), Aix (1585) and Toulouse (1590).

92 Concilia, ed. Odespun, pp. 98, 423; Le Concile provincial des diocèses de Normandie tenu à Rouen l'an MDLXXXI, par monseigneur l'illustrissime et révérendissime cardinal de Bourbon archévêsque du dict lieu, corrigé et confirmé par nostre sainct père le pape Gregoire XIII (Paris 1582), p. 31; Venard, 'Embrun', 634.

93 Concile provincial, pp. 54-5: 'Entre les charges des Évesques l'une des principales . . . est la visitation, de laquelle le premièr but doit êstre d'introduire et maintenir la saine et droicte doctrine ... .; soustenir et continuer les bonnes moeurs ...., esmouvoir et enflamber le peuple par exhortations et rémonstrances à la vraye religion, et au reste ordonner toutes hoses à l'edification des fidèles.' see also Concilia, ed. Odespun, pp. 249-50, 313-17, 476, 497; Venard, 'Embrun', 636.

94 Venard, 'Embrun', 636.

95 Vernard, 'Henri IV', 306; Statuts renouvellez par R. Père François de La Rochefoucault évesque de Clairmont: et publiez au S. synode tenu audict Clairmont le vingtuniéme jour d'octobre 1599 (Clermont 1599); Villars, Opuscules, ii, p. 497.

96 Terrebasse, Villars, p. 6.

97 Villars, Opuscules, i and ii.

98 Ibid., ii, epistle to Pope Clement VIII (unpaginated).

99 Cinq Visites, ed. Contrasty, pp. 53-4.

100 Ibid., pp. 42-3.

101 Venard, Réforme, p. 1101.

102 Barthélemy des Martyrs, Stimulus pastorum, ex sententiis patrum concinnatus in quo agitur de vita et moribus episcoporum aliorumque praelatorum (Rome 1564); Almeida Rolo, L'Evêque, p. 369.

103 In 1582, 1583 and 1586 (two editions). In the seventeenth century, editions appeared in 1622, 1658 and 1667. For this study, I have used the modern edition, published in Braga in 1963.

104 Martyrs, Stimulus, pp. 139-83.

105 Agostino Valier, Discours en manière d'instruction de ce qui appartient à la dignité épiscopale, trans. Chrétien d'Ebrard de Saint Sulpice (Paris 1585).

106 Nicolas Marzac, The Library of a French Bishop in the Late Sixteenth Century (Paris 1974), pp. 21-3.

107 The standard biography is R. L. Oechslin, Louis de Granada (London 1962).

108 Louis de Grenade, De officio et moribus episcoporum aliorumque praelatorum (Lisbon 1565); Jedin, L'Evêque, p. 93. 
109 Louis de Grenade, Ecclesiasticae rhetoricae, sive De ratione concionandi (Lisbon 1576); Agostino Valier, De rhetorica ecclesiastica (Paris 1575) (1st edition, Verona 1574); Diego de Estella, Modo de predicar y modus concionandi. Estudio doctrinal y edicion critica (Salamanca 1576).

110 John O’Malley, 'Saint Charles Borromeo and the Praecipuum episcoporum munus. His Place in the History of Preaching', in Headley and Tomaro (eds), Borromeo, p. 148.

111 Wright, 'Ribera'.

112 Concilia, ed. Odespun, pp. 98-100, 471-2; Concile provincial, p. 32; Venard, 'Embrun', 634.

113 Concile provincial, p. 54; Concilia, ed. Odespun, pp. 479-80; Venard, 'Embrun', 636.

114 Concile provincial, p. 32; Concilia, ed. Odespun, p. 294.

115 Agostino Valier, Vita Caroli Borromei card. S. Praxedis (Verona 1586); Carlo Bascapé, De vita et rebus gestis Caroli, S. R. E. cardinalis, tituli S. Praxedis, archiepiscopi Mediolani (Ingolstadt 1592).

116 Logan, Venetian Clergy, p. 238.

117 Massaut, Clichtove, ii, p. 57; Piton, 'L'Ideal', 79, 104; Vansteenberghe, 'Programme', 26.

118 Piton, 'L'Ideal', 397; Vansteenberghe, 'Programme', 31-2, 35-6. Besides his own works, Gerson also recommended the Summa theologiae and Guillaume Pérault's Somme des vices et des vertus.

119 Pascoe, Gerson, pp. 110-38. 


\section{2 \\ The most perfect state: French clerical reformers and episcopal status}

As a general council of the church, Trent offered a framework within which a resurgent catholicism could take shape. To a man, its delegates took it for granted that the clergy would lead the laity, and that bishops would supervise and govern all the faithful. While the conciliar decrees were designed to respond, therefore, to the specific abuses and inadequacies of contemporary religion, they drew equally on what were assumed to be eternally applicable principles of hierarchy and authority. The church had always possessed its leaders and its followers; that was both a practical necessity and God's plan. Both had to be accommodated in permanent rules that would preserve the church until the end of time. While this projection of episcopal leadership was to provoke opposition from some quarters, many reformers rose to the challenges that it had identified by building on its platforms of hierarchy and reform. Leading theologians and reformers embarked on extended explorations of what 'reform' meant and how it could be achieved within a hierarchical church. Their imprint could be seen before the end of the sixteenth century, but no one was to have more impact than the French reformers of the seventeenth century.

This 'school of priesthood' developed a sacerdotal theology and training methods which were still standard sources for the formation of Catholic priests during the twentieth century; through the seventeenth and eighteenth centuries, its members' understanding of the ministry was widely diffused both within and outside France and they gradually succeeded in implementing many of their aims for clerical renewal within the French church. Yet historians have tended to neglect the fact that they made equally strong contributions to episcopal ideals and behaviour. ${ }^{1}$ When they do acknowledge it, they do not delve any deeper to identify precisely what type of bishop these influential ecclesiastics were so keen to see within episcopal ranks. ${ }^{2}$ Yet behind the assumption that the reformers intended to actualise their episcopal ideal lie key, as yet untackled, questions. What was that ideal? From where did these men draw the material on which their vision of the good bishop was established? In what ways did 
they use this material to formulate an adapted vision of episcopacy that was designed to respond to the needs of the seventeenth-century French church? In answering these questions, we may begin to appreciate fully the objectives of French clerical reformers and indeed to conceive their impact on the episcopate and, more broadly, on the French church.

Just a cursory examination of the extant correspondence of French reformers reveals the web of contacts between these like-minded individuals through the seventeenth century. Their informal exchanges of opinion mean that a significant degree of cross-fertilisation occurred in the development of their theologies, so that the work of each reformer can never be deemed exclusively influenced by one individual, but rather by a combination of complementary strands of thought. Their ranks include very well-known clerics like Vincent de Paul and Louis Tronson, energetic reformers singled out by historians as key figures in the French reform movement. Yet if any seventeenthcentury figure may be termed the founder of the theology of priesthood, it is Cardinal Pierre de Bérulle (1575-1629), on whom all later writers on priesthood and reforming activists drew heavily. His reflections culminated in the formation in 1611, of the Congregation of the Oratory, a company of dedicated secular priests who would correspond to their founder's notion of the clerical vocation. When Bérulle died in 1629, the Oratory numbered approximately four hundred members, housed in over sixty locations and overseeing many students training for the priesthood in regions including Rouen, Clermont, Nantes and Lyon. By 1702, the number of houses had risen to eightyfive, though the Congregation's members still hovered around 400. ${ }^{3}$ Its communities were by then dotted throughout France, and remained permeated with the Bérullian theological ethos. This was largely due to the energies of successive superior-generals such as Charles de Condren (tenure 1629-41) and François Bourgoing (tenure 1641-62), both long-time disciples of Bérulle who absorbed his theological structures and ideas into their own writings for priests and novices. ${ }^{4}$ Bourgoing also obtained official papal approval of the Congregation's statutes (1654), and it was under his generalate that the first edition of Bérulle's writings was published, complete with a long preface outlining the chief characteristics of the cardinal's teaching. ${ }^{5}$

Although Bérulle's thought developed throughout his life, it was deeply indebted to the theological genres to which he was exposed during his youth. The young priest visited his cousin, Barbe Acarie, in whose mystical circle abnegationist spirituality was dominant, daily for over six years in the 1590 s. $^{6}$ In general, excepting Brémond's indispensable study of its spiritual character, we know relatively little about this influential cluster of early dévots. ${ }^{7}$ It has been suggested that the coterie's origins lay in the years following the religious wars when the failure of the League and the crowning of a former heretic as king of 
France contributed to an acute sense of ideological and religious uncertainty among sections of the nobility who had supported the Catholic League. The Acarie circle's spirituality may have been one of the many responses to that sense of uncertainty: a turn to more inward and personal spirituality in an effort to regain spiritual assurance, rather than to the formulaic religious practices popular during the League era. ${ }^{8}$ It is certain, however, that, within this tight network, Bérulle maintained regular contact with a number of important spiritual figures including the Capuchin Benoît de Canfeld and the Carthusian Dom Beaucousin.

This group's mystical spirituality borrowed from the theology of PseudoDionysius, who retained considerable popularity in the sixteenth and seventeenth centuries and was widely, though mistakenly, held in renown as the learned companion of Saint Paul and patron of France. ${ }^{9}$ His theology proved particularly suited to these early dévots' mystical mentality because of its emphasis on the hierarchical structure of divine and human relations and its predilection for a negative ascent to God by self-renunciation. Importantly too, in stressing the necessity of ecclesiastical hierarchy, this theology managed to counteract the more extreme and unorthodox possibilities of individualist mysticism. The mystical spirituality favoured by the Acarie circle focused on complete self-renunciation in order to achieve intimacy with God, so that it promoted obedience to the divine will as its fundamental spiritual principle. It incorporated a specifically hierarchical understanding of society in which the world was theocentric and thearchic, that is, hierarchically structured, with God at its summit. Only through divine illumination could one ascend to union with the transcendent and supreme Godhead. The most vital qualities of the Christian were, consequently, self-abnegation, complete trust in God and constant intensive prayer. $^{10}$ Bérulle's youthful exposure to Dionysian theology meant that his own sacerdotal theory was also to draw heavily on PseudoDionysius's hierarchical structures. Yet it should not be assumed that PseudoDionysius was the sole influence on Bérulle's theology. Most particularly, he incorporated Augustinian doctrines into his thought, which enabled him to modify Dionysian hierarchy in a way that placed Jesus Christ, the God-man, at the core of mystical ascent. ${ }^{11}$ This blending of traditions directly informed his conceptions of priesthood and episcopacy.

In 1611, Bérulle founded the Congregation of the Oratory hoping, as he put it in his 'Projet de l'érection de la Congrégation de l'Oratoire de Jésus', to re-establish 'virtue and perfection in the sacerdotal state'. ${ }^{12}$ This aspiration was the product of his evolving theology of priesthood which was based, above all, on the innate and magnificent dignity of the sacerdotal order. It, in turn, was directly related to the Christocentric nature of his thought and to his adoption of a modified Dionysian hierarchical structure as the framework for this. ${ }^{13}$ 
Assuming, as Trent and countless other theologians had done, that the true order of the Catholic church was a divinely ordained hierarchy, Bérulle began by dividing the ecclesiastical hierarchy into three triads, then subdivided each triad into ranks (Figure 1). This structure imitated the divisions of the heavenly hierarchy: its highest triad was composed (in descending order) of seraphim, cherubim and thrones, the second of dominions, powers and authorities, and the third of principalities, archangels and angels. The three triads of the ecclesiastical hierarchy consisted of 'the operations of the sacraments, the godlike dispensers of the sacred things and those guided by them (the dispensers) . . . towards the sacred'. The highest division housed baptism, the eucharist and unction while the third held monastic orders, initiates (or holy people) and catechumens (those not yet admitted to the sacraments). Most importantly for our purpose, Bérulle placed hierarchs or bishops, priests and deacons in the middle triad. ${ }^{14}$

\section{Figure 1 Bérulle's interpretation of the heavenly and ecclesiastical hierarchies}

\begin{tabular}{|c|c|}
\hline \multicolumn{2}{|l|}{ The heavenly hierarchy } \\
\hline Triad I & $\begin{array}{l}\text { seraphim } \\
\text { cherubim } \\
\text { thrones }\end{array}$ \\
\hline Triad II & $\begin{array}{l}\text { dominions } \\
\text { powers } \\
\text { authorities }\end{array}$ \\
\hline Triad III & $\begin{array}{l}\text { principalities } \\
\text { archangels } \\
\text { angels }\end{array}$ \\
\hline \multicolumn{2}{|l|}{ The ecclesiastical hierarchy } \\
\hline Triad I (operations of the sacraments) & $\begin{array}{l}\text { baptism } \\
\text { eucharist } \\
\text { unction }\end{array}$ \\
\hline Triad II (dispensers of the sacred things) & $\begin{array}{l}\text { bishops } \\
\text { priests } \\
\text { deacons }\end{array}$ \\
\hline Triad III (those guided by the dispensers) & $\begin{array}{l}\text { monastic orders } \\
\text { initiates } \\
\text { catechumens }\end{array}$ \\
\hline
\end{tabular}

Within this hierarchy, the priest had a crucial role. He was the mediator of divine grace, whose duty it was to draw those below him in rank towards 
union with God through administration of the sacraments, particularly the eucharist. The source of and the figure who instituted the sacramental priesthood was Jesus Christ, the eternal priest through his death, resurrection and ascension to Heaven; for Bérulle, the elevated dignity of the priestly vocation rested on this foundational link with Christ's priesthood. Through the sacrament of ordination Christ delegated his authority, enabling those legitimately ordained to continue his salvific work. ${ }^{15}$ Priests acted, therefore, 'like instruments in his hands' ${ }^{16}$ They were particularly close to Christ because they acted as his visible representatives on earth, illuminating those below them in the ecclesiastical hierarchy and drawing them closer to union with God. They held 'a power so elevated' that even the angels in their state of glory were not worthy of it. ${ }^{17}$

The supreme dignity of priesthood, however, brought weighty obligations to those who were called to it. The priest's unique position required that he dedicate himself fully to the bond linking him to Christ, consistently striving to live according to the status and sanctity of his vocation. He could fulfil this obligation, however, only if he were entirely responsive to God. Selfrenunciation was, therefore, essential in order that the priest could dwell in a state of utter receptivity to the divine will. Each priest had to depend entirely on the heavenly power in order 'to act only by him and for him'. ${ }^{18}$ Vows of servitude to Jesus and the Virgin Mary that Bérulle devised for Oratorian priests and for the Carmelites under his direction were understood as steps towards this goal, though he wished every priest to attain complete union with God, in correspondence with the nature of his vocation. ${ }^{19}$ The priest was a servant of God, a role involving his sacrificial oblation. As mediator between the divine and human, he was obliged to offer himself to God as victim for the sins of others, just as the Son offered himself in sacrifice to the Father for the redemption of mankind. This notion of sacrificial oblation was an element of Bérulle's theology, but was brought to maturity by Charles de Condren, who presented it as 'the most worthy way of adoring God'.$^{20}$ For Condren, it was the highest form of holiness since it ultimately brought the victim back to union with the Father.

Both Bérulle and Condren insisted that those called to the glory of priesthood had to be personally 'sanctified'. 'The priesthood is a state that is divine in its operation and ministry . . . the origin of all the holiness . . in the Church. ${ }^{21}$ By the sacrament of ordination, the priest was consecrated to a life of imitation of Jesus Christ. ${ }^{22}$ As Christ was holy, so too the priest must aspire, through constant mystical servitude and sacrifice, to internal as well as external sanctification. ${ }^{23}$ Relating his theology to the practical demands of the seventeenth-century church, Bérulle urged that priests return to their inheritance of 'authority, holiness and light (doctrine)'. But, here, Bérulle modified Dionysius's doctrine, principally founding the priest's role as mediator on his authority, passed down 
through history, rather than on his 'illumination' through wisdom. He continued to retain elements of Dionysian theology, however, emphasising that the hierarchical position of priests reflected their degree of 'divinisation' or intimacy with the divine and that their lives should in turn mirror this closeness. Indeed, it could not be expected that others would be drawn to holiness if those who led them were not first an example of sanctity. ${ }^{24}$

By restoring a Christocentric element to hierarchical mediation, the cardinal adapted Dionysian hierarchy so that the office of priest was placed at the core of his theology. This assumption ensured that new developments in the understanding of priesthood were bound to affect those who coexisted with them in this framework, for priests did not exist in isolation but in reciprocal communication with other members of the church. Any emphasis on the dignity and character of the sacerdotal office would necessarily have implications for those both above and below them in hierarchical rank. Specifically, it exalted the status and power of bishops.

In stressing the dignity of the Catholic priesthood, Bérulle could not have been unaware of the possibility that others with differing motives would hijack the principle. If he needed any reminder of this risk, he had only to observe the contemporary furore surrounding Edmund Richer's Libellus de ecclesiastica et politica potestate, ${ }^{25}$ published precisely at the time when Bérulle was formulating the core principles of his theology and planning the establishment of his Congregation. ${ }^{26}$ Richerism's trenchant defence of the right of curés to share in ecclesiastical government could conceivably find Bérullian hierarchy extremely fruitful in justifying its claims. But Bérulle was certainly not a supporter of curial government within the church, and his conception of hierarchy was designed to guard against such democratisation of ecclesiastical discipline. As a result, from the beginning of his career as a reformer he concentrated on developing the notion of episcopal authority and dignity and in doing so, justified his claim that priests should render obedience to their bishops.

This principle was in place as early as 1610 . Bérulle's 'Projet' for the establishment of the Oratory clearly enunciated the Congregation's reliance on the authority of bishops: '[The Oratory] will be joined to prelates by the vow of obedience, regarding the exercise and employment of ecclesiastical functions.' That principle was further underlined in the Projet's confirmation that no member of the Congregation would actively seek employment from bishops or anticipate their commands. ${ }^{27}$ Bérulle consistently adhered to this policy throughout his tenure as superior of the Congregation and it was officially continued under his successors. ${ }^{28}$ Displaying again the influence of Dionysian hierarchy, Bérulle consistently claimed that relationships between bishops and priests ought to mirror that which existed between archangels and angels in the celestial hierarchy. In 
this analogy, priests were earthly angels acting as mediators 'of God's counsels' . Bishops, however, were in command of priests since they were the earthly manifestation of the archangels..$^{29}$ So although Bérulle heightened the status of priesthood within his hierarchical pattern, he was careful to elaborate a doctrine which placed bishops above them in authority and which called on episcopal authority to encourage clerical sanctification. By ensuring the maintenance of discipline among the Oratorians, the goal of the renewed sanctification of priesthood could be achieved.

Committing the ecclesiastical activities of Oratorians to episcopal jurisdiction no doubt influenced the decisions of prelates to permit the Congregation to operate in their dioceses, and Bérulle was surely conscious of this. But, besides the practical consideration of ecclesiastical discipline, on what grounds did Bérulle justify episcopal authority over priests? Just as he had legitimised the mediatory role of priests by reference to the authority transmitted to them through the church's history, he pointed to the example of the early church where bishops had governed perfectly devout lower clergy. This was the organisational ideal to which the seventeenth-century church should now return. ${ }^{30}$ Returning to Dionysian theology, the cardinal also presented the bishop as the figure who, as grand prêtre, enjoyed the closest relations with God of anyone in the church. According to Pseudo-Dionysius, the bishops were the most enlightened and the most godlike of hierarchical members. They mediated their knowledge of divine truths to those inferior to them in rank, perfecting them through teaching and the administration of orders and confirmation. ${ }^{31}$ For this reason, Bérulle confirmed the right of bishops to govern their clergy since they possessed the greatest knowledge of God's will. Priests then were mediators of God's grace by virtue of the authority attributed to them by historical succession, but bishops, in Bérullian thought, were the supreme mediators whose authority could be traced to the early church. While priests illuminated those of the lower hierarchical grades, bishops drew them to perfection through revelation. Theirs was the most divinised rank of the ecclesiastical hierarchy since it contained within itself the grace of all the ranks beneath it and the clearest view of divine truths. The dignity of the episcopal office, therefore, was supreme within the ecclesiastical hierarchy.

The episcopal office thus completed and fulfilled the whole arrangement of the ecclesiastical hierarchy. Its enlightened members were able to purify, illuminate and perfect. However, just as Bérulle believed the tremendous dignity and privileges of priesthood to carry onerous obligations of sanctity and servitude, so too he believed that the episcopal office demanded remarkable personal sanctity. In fact, the bishop's degree of holiness must be greater and more intense than that of any other hierarchical member in order to correspond to the sublime status of his office. Importantly too, the 'sanctified' bishop would act as 
an example to his charges, actualising in his own life all that he taught to others to perfect them. The ecclesiastical hierarchy was one of both order and sanctity therefore, and because the episcopal state was situated at its summit, its members must live according to the character and obligations of that position. ${ }^{32}$ When Bérulle, consequently, wrote to Daniel de La Mothe-Houdancourt in the wake of the latter's appointment to the diocese of Mende, he pointed out that the honour paid to him by the king and the congratulations offered by wellwishers should be of far less value to him than the obligations to which he was now consecrated. ${ }^{33}$ For Bérulle, worldly compliments meant little. His concern was that bishops fulfil their office in a manner worthy of its character.

Bérulle believed the announcement of God's word by bishops to be the most efficacious form of teaching, as he told one prelate with whom he corresponded. ${ }^{34}$ But the bishop was obliged to ensure that he was fully receptive to the divine will and to the truths God communicated to him so that he could, without selfish interests, reveal them to those beneath him in hierarchical rank and thus draw them towards perfect union with their Creator. The only way for bishops to guarantee their correspondence with God's will and truths was, according to Bérulle, 'to strive for divine splendour itself and to keep their eyes fixed on it, as is proper to their sacred character' ${ }^{35}$ In conformity with the mystical spirit of Bérullian thought as a whole, complete self-renunciation was vital in order to destroy personal will, for God was to be 'the end and principle' of the bishop's work of enlightenment and perfection. ${ }^{36}$ In some instances, Bérulle added, the hierarch might be unaware that he was acting under the infusion of divine knowledge, but what was crucial to his work was the fact that he actively aspired towards complete servitude of God and was consequently entirely receptive to and dependent on the revelation of his wishes. ${ }^{37}$ Bérulle was capable of connecting theory to practice here, as when he suggested the appointment of Bernard Despruets to the diocese of Saintes in 1627. In a letter to Richelieu, the Oratorian noted Despruets's lack of personal ambition to be a bishop and indicated that this quality of worldly detachment was 'of great example' to others. ${ }^{38}$ Those prelates who abandoned their own interests in selfless servitude of God would be truly 'divinised' ${ }^{39}$

The pervasive influence of Bérullian views of episcopacy in the writings and work of his successors and disciples is plain. Of course, this is not surprising if we consider the network of relations among those French clerics actively involved in clerical reform during the seventeenth century. Two leading reformers, Jean Eudes (1601-80) and Jean-Jacques Olier (1608-57), who both made original contributions to the theologies of priesthood and episcopacy, were members of the Oratory before founding their respective sacerdotal congregations. Jean Eudes was Oratorian superior at Caen before establishing the 
Congregation of Jesus and Mary in 1643 and had benefited from the personal spiritual direction of both Bérulle and Condren. ${ }^{40}$ Like them, he considered his life to be dedicated to the formation of worthy and devout priests through the establishment of seminaries ${ }^{41}$ and through the instructional texts that he published until his death in $1680 .{ }^{42}$ In his attitude to the priesthood, Eudes was of the Oratorian mould. Certainly the prime emphasis and the origin of his thought was the dignity of the priestly state, followed closely by the directly consequent requirement of sanctity for those called to it. The Mémorial de la vie ecclésiastique, a summary of Eudes's thought which was printed only posthumously but had been completed by the early $1670 \mathrm{~s},{ }^{43}$ expressed this belief in detail. Addressing priests directly, Eudes noted that they were greater than angels in power and authority, but that they should also be so in 'purity and sanctity'. Their grandeur was due, he then stated, to their being sacrificers, sanctifiers, mediators, judges and saviours, authorised by Jesus Christ to continue his work of redemption. ${ }^{44}$ This was the classic vein of sacerdotal thought developed by Bérulle and Condren. Indeed, by asserting the superiority of priests over angels in power and authority, Eudes advanced further than either of his forerunners. Bérulle had compared priests and bishops to angels and archangels respectively, but for Eudes the power and authority of priests surpassed that of the angels. It may be safely assumed that he considered bishops to surpass archangels in power and authority. Like Bérulle, in glorifying the status of priesthood he glorified that of bishops, but he did so to a more radical degree.

Eudes' understanding of episcopal superiority over priests was most manifestly illustrated in the authority that he wished bishops to have over the members of his Congregation working in dioceses. As Bérulle insisted for the Oratory, those members of the Eudist Congregation who engaged in ecclesiastical activities were under obedience to the local bishop. As a result, Eudes was able to assure the archbishop of Rouen, Harlay de Champvallon, that his priests were entirely at the episcopate's disposition, each of them making a profession to that end. ${ }^{45}$ His acceptance of episcopal authority was consequent on his belief in the superior dignity of bishops. As the uppermost rank in the ecclesiastical hierarchy, bishops exercised paternal authority over the priests who were their children. Although Eudes regarded all priests as fathers of Christians because of their likeness to Christ, he believed that bishops were additionally the fathers of priests because they were 'God in a more eminent degree'. ${ }^{46}$ The hierarchical theory of Pseudo-Dionysius, as adapted by Bérulle and by Condren, was intrinsic to Eudes's understanding of the episcopal state. Bishops were the most perfect rank of the hierarchy and held authority over priests as a result of their enlightened, 'divinised', intimacy with God. Eudes was, however, aware of the demands which such elevated status brought to appointees. In urging Claude Auvry to accept the vacant bishopric of Bayeux if it was offered to him, as Eudes 
hoped, he stressed the opportunity for service in episcopal functions which were 'so beautiful, so noble, so holy and so divine'. These functions Eudes identified as those pertaining to the health of souls, though he did not detail them individually. Such work was 'the work of works, the most divine of the divine', and Auvry could engage in no worthier activity. ${ }^{47}$ Yet Eudes, though acutely aware of the status of episcopacy and consistently formulating his thought in terms appropriate to it, was also conscious of the onerous obligations on bishops for the salvation of souls. Good bishops, he noted in a letter of 1648 to the queen mother, urging her to choose worthy episcopal candidates, would make good Christians. ${ }^{48}$

Jean Eudes offered even greater authority and perfection to the office of bishop than his predecessor, Pierre de Bérulle. Among the leading clerical reformers of the period it was, however, Jean-Jacques Olier who provided the most defined and sophisticated description of episcopacy. Like Eudes, Olier was the product of Oratorian formation before establishing the Sulpician Congregation of priests in 1645, and was particularly influenced in his theology of priesthood by Charles de Condren, his spiritual director between 1635 and $1641 .{ }^{49}$ Like earlier clerical reformers he was fundamentally concerned with the formation of priests worthy of their vocations and established the Sulpician seminaries to this end. Of all the new congregations which assumed the management of seminaries, the Sulpician was the most successful in attracting the future leaders of the French church; by the latter part of the eighteenth century, 60 per cent of French bishops had been trained, generally for a period of three years, in its Parisian seminary. ${ }^{50}$ The Congregation also controlled important seminaries in other centres, such as Nantes, Viviers and Le Puy, from where it shipped forth its own members and non-affiliated diocesan clergy. Like Bérulle, Olier was succeeded by superiors who reinforced his sacerdotal and episcopal ideas: it was Louis Tronson (1622-1700), Sulpician superior between 1671 and 1700, who, after producing an edited edition of Olier's correspondence, published the Traité des saints ordres par M. Olier in 1676, a collection of miscellaneous observations on holy orders, culled from Olier's journal and other papers. ${ }^{51}$ He also produced several tracts designed to aid the formation of priests, all of which reiterated the theological, spiritual and organisational principles of his predecessor. ${ }^{52}$ Tronson's correspondence demonstrates that he continued to cultivate the close connections developed by Olier with members of the episcopate, providing spiritual counsel to renowned prelates like Fénelon, bishop of Cambrai, and the bishop of Limoges, Louis de Lascaris d'Urfé. ${ }^{53}$ Fénelon was in persistent contact with Tronson from his time as a young priest in Paris during the 1670s until the Sulpician's death in 1700, and regarded Tronson as his 'father for ecclesiastical life'. He believed himself equally indebted to Jean-Jacques Olier, writing in 
1706 that 'Although I never saw Monsieur Olier, nothing I heard of his conduct and maxims failed to make a profound impression. ${ }^{54}$

These maxims were fundamentally indebted to Olier's youthful career within the Oratorian Congregation. As a reformer within the Bérullian tradition, Olier considered the privilege of participation in the priesthood of Jesus Christ, whereby the ordained 'must be regarded as a living Jesus Christ', to be a tremendous honour but one to be assumed with extreme gravity. Through his holy ministerial office, the priest was both the sacrament and the victim of Jesus Christ, mediating divine grace to the faithful. Olier meant that the priest, as the living sacrament of Jesus, gave the body, spirit and sacrifice of the saviour to the church, chiefly by celebrating the eucharist. ${ }^{55} \mathrm{He}$ thus drew the faithful towards union with God, acting as the mediatory instrument through which illuminating grace was passed downwards from the divine. As victim, however, the priest reached his highest possible holiness and fulfilled his obligation to be 'a marvel of sanctity'. He should offer his whole self in servitude to God and, moreover, act as a victim for the sins of the world like Jesus on the cross ${ }^{56}$ Selfless servitude through sacrifice was both the privilege and the demand of the priestly state.

Since Olier's conception of priesthood, with its dignity and attendant responsibilities, was so close to the Bérullian spirit, it is hardly surprising that he should share the latter's understanding of episcopacy. But although Olier was patently influenced by his Oratorian formation, he proved a good deal more expansive and precise upon this issue than any of the period's other leading clerical reformers. Indeed, because the Sulpician founder both adopted and augmented previous contributions in formulating his own distinctive convictions, his contribution may be considered the pinnacle and ultimate definition of the school's thought on episcopacy. His beliefs were set out most precisely in the 'Projet de l'établissement d'un séminaire dans un diocèse', which he presented to the Assembly of Clergy in 1651 and circulated to all French bishops. ${ }^{57}$ This was not the only text through which Olier communicated his views but it provided the most coherent and detailed description of them and is, for this reason, an indispensable primary source. ${ }^{58}$ In the letter accompanying his proposal, Olier confirmed that he offered the 'Projet' to the prelates of the Assembly in order to gain their public approval of the Sulpicians' seminary work and in order that the clergy involved in this work could be enlightened, animated and directed by the episcopate. ${ }^{59}$

As for Bérulle, Condren, and indeed for the Council of Trent, the presence of a divinely ordained church hierarchy was a crucial assumption in Olier's episcopal and sacerdotal thought. He accepted the Dionysian format which situated bishops at the summit of this hierarchy in their 'holy grandeur' and delineated the characteristics of the episcopal office in relation to this system. ${ }^{60}$ 
Within the framework of the ecclesiastical hierarchy, 'an intimate union' existed between bishops and priests, which established the latter in a state of reliance on the former, their hierarchical superiors. In the contemporary church, however, Olier believed this natural and divinely instituted union to have been ruptured with the result that 'One sees the principal ministers of Bishops, who are the Priests, living without dependence on their Leaders' and, worse still, with no 'respect for their sacred direction nor attachment of obedience'. He doubly regretted this since, in his opinion, the contemporary episcopate had found renewed zeal for its work, but found itself bereft of the necessary clerical support for its activities. It was essential, as a result, that unity between bishops and priests be restored to its original state if the church was to operate fruitfully. ${ }^{61}$ The most opportune means of achieving this was through the foundation of seminaries, directed by the bishop through delegated agents. ${ }^{62}$

To express his idea of the natural relationship between bishops and priests, Olier adopted the three fundamental episcopal titles of father, leader (the word chef may equivalently be translated as 'head', with the same meaning as 'leader') and king. It is immediately obvious from his use of these titles that Olier considered the relationship between bishop and priest to be based on hierarchical rank, with the former functioning as the superior of the latter. ${ }^{63} \mathrm{Of}$ course, the image of the bishop as father was not a new concept, for it had originated with Saint Paul's advice to Timothy before being incorporated into the Pastoral Rule of Gregory the Great and the decrees of the Council of Trent. ${ }^{64}$ Olier drew, therefore, on venerable tradition when he described his vision of episcopal parenthood. He believed the bishop to be, as father, the creator and nurturer of the children of faith, in the same way as the divine Father eternally created and nourished his Son. The zeal of prelates for this function was of far greater magnitude than that of priests since God dwelled in them to a greater degree: they were more godlike than other members of the ecclesiastical hierarchy. Bishops, Olier argued, were more fecund in their ability to nurture souls, a quality complemented by their intense ardour for the distribution of the nourishing divine word to their children. Their compassionate paternalism included, in addition to the provision of spiritual sustenance, 'tenderness to caress their children, mildness to suffer them in their weakness, strength to carry them in their frailty, wisdom to correct them in their faults, knowledge to light their darkness, joy to console them in their afflictions'. All of these, Olier concluded, were granted by God to bishops to enable them to guide their flock and 'to raise it to the perfection of Christian life' ${ }^{65}$

Jean Eudes, writing around the same time as Olier, also referred to the paternal quality of the episcopal office. It is particularly noteworthy, however, that Olier attributed such prominence to the specific quality of compassionate paternalism. Certainly it was not a conspicuous element of Bérulle's, or even 
of Eudes's, episcopal reflections, which were principally concerned with obedience to the superior jurisdictional authority of bishops as a function of their supreme hierarchical rank. Moreover, despite devoting attention to the mediatory role of bishops in justifying their authority over priests, the cardinal did not describe the episcopal office in terms of pastoral paternalism. Olier's thinking thus ranged more widely than that of Bérulle, for it assigned more prominence to the pastoral role of the bishop and elaborated on the virtues of love, gentleness, strength, wisdom and joy that this responsibility entailed. The notion of the bishop as father did include an element of jurisdictional authority, but it was a role that simultaneously stressed the love of the father for his children and the mutual respect and affection that should exist between them. In a letter to Bishop Caulet, Olier highlighted this reciprocal bond of affection. Advising Caulet on the best way to achieve equilibrial relations with his chapter, Olier claimed that there was nothing in 'authority or pontifical rights which might be so essential that the way[s] of mildness and clemency do not prevail. Make it clear to them that you could have acted differently in respect of the wrong done . . . but that the feeling [entrails] of a Father and the charity of a spouse do not permit you to do so in this instance. ${ }^{66} \mathrm{~A}$ spirit of benevolence was to govern the relationship between the bishop and his canons, based on his fatherly fondness for them. Olier's vision was focused as much on the positive aspects of authority as on the constrictions and discipline which it entailed. The obedience of the faithful to their bishop was based on their goodwill towards and love for the father who guided them, as well as on the demand for submission to the authority that his superior hierarchical dignity demanded. Furthermore, by detailing the virtues of the paternal prelate Olier drew attention to the personal sanctity of bishops, a theme virtually untreated by Bérulle, Condren or Eudes. He listed piety, distrust of the world, frugality, honesty, zeal, hatred of sin and humility as essential virtues of the good bishop. ${ }^{67}$ Bérulle had understood personal perfection as a function of the excellence of the hierarchical office but he did not detail the merits that comprised this form of perfection, and nor did Condren or Eudes. In this way too, Olier expanded on his predecessors, producing a more detailed and more thorough episcopal image through the development of a traditional episcopal theme.

In characterising bishops as leaders Olier confirmed, as through the title of father, the authority of their office over those beneath it in the hierarchy. Episcopal leadership did not, however, simply rest on jurisdictional authority, though this was certainly an aspect of it. Rather, Olier's understanding of the notion was primarily related to the issue of sacramental order, and it is here that the concept of leadership as 'headship' is demonstrated most effectively. According to his theology, bishops contained within themselves a plenitude of spirit which they transmitted to their clergy, animating them with the virtue 
necessary to their state. Olier described the operation as a flowing of grace 'from the leader [head] into the members by his natural joints and by his ligaments, his veins and his nerves prepared for the distribution of spirits and for the communication of his life', evoking bodily analogies popular at his time of writing. Olier supposed this episcopal spirit to be intrinsic to the character of the office, asserting that 'The grace which will not be spread from the head in his members . . . will animate only half the holy members of this body.' So the bishop and his priests formed one body, with the bishop as head, animating his clergy by the grace that flowed through the appropriate connecting channels. The existence of bishops was thus absolutely essential to the structure of the church and to the functioning of the lower clergy. ${ }^{68}$

In asserting the existence of a vivifying or perfecting spirit within the bishop which he communicated to priests, however, Olier identified a crucial distinction between the characters of the two states. He did not claim that the episcopate was a separate sacrament from the priesthood, but equally he did not support the contrary extreme which understood the episcopate as simply or merely an extension of it. In the latter case, the episcopate and the priesthood would be equal in all respects but that of jurisdiction. Sacramentally, there would be no difference between a bishop and a priest: both would have the power of eucharistic consecration, while the bishop's superiority would be just a result of the jurisdictional authority to which his office entitled him. Olier's view followed the later doctrine of Thomas Aquinas which proposed a distinction of order as well as of jurisdiction between priesthood and episcopate, while maintaining their sacramental unity. Of course, Aquinas was not the definitive voice of authority within the Catholic church; it was far more important that the Council of Trent had adopted just this view in its decree on orders. Olier was much more expansive than the Council, however, colouring in its bare sketch with a detailed theological image of the dynamic relationship between bishops and their priests. In fact, through his assertion of a specifically episcopal character, he reached the conclusion towards which the thought of Pierre de Bérulle had progressed but which it had not explicitly affirmed. Following Dionysian theology, Bérulle confirmed the perfecting power of bishops on those below them in hierarchical rank, but it was Jean-Jacques Olier who precisely identified this capability to be the product of a special grace which was unique to consecrated bishops and on which priests were dependent to attain full sanctity. They were not merely transmitters, but actual and essential sources of grace. Bishops differed from priests not only in terms of jurisdiction and in the more intense obligation for personal sanctity which their office demanded, but also in the very character of that office.

Olier's notion of a vitalising leadership also broadened the question of episcopacy from primarily one of authority and jurisdiction to one of pastoral 
care. He was profoundly aware of the hazards risked by over-emphasising the disciplinary aspects of episcopal authority to the detriment of paternal guidance and benevolent animation. Too many bishops, he wrote to Étienne Caulet, merely exercised their functions of police and justice, 'being thus in suspension of the principal functions of the spirit which must vivify their diocese'. It was essential that the bishop inspire his clergy so that the latter 'are the signs of the life of the spirit and of the unction which lives in him and which he sends out of himself'. But he had to ensure that personal interests did not distort the operation of that spirit. Returning to the mystical spirituality which characterised his sacerdotal theology, Olier insisted on the necessity of Christ-like self-renunciation so that the episcopal spirit could operate with complete liberty. A bishop's authority was not, therefore, simply a matter of discipline and of obedience to precepts and ordinances but a positive animation and nourishment of his clergy by means of the supreme reserve of grace that derived from his consecration. Suitably vivified clergy would in turn spread the unction transmitted to them to those below them so that the 'spirit of the holy prelate releases sanctification in the people' ${ }^{69}$

Fatherhood and leadership revealed the pastoral element in Olier's thought while retaining their foundations in the hierarchical authority of the episcopate. His use of the theme of kingship was more purely concerned with matters of government and obedience, and it was under this banner that the grandeur of the episcopal office was particularly stressed. In his treatment of this theme Olier's opinion most closely resembled the contributions of other leading clerical reformers to episcopal theory. As king, the bishop inherited the grandeur of the supreme monarch, Jesus Christ, just as he inherited his headship. He was the earthly ruler of the 'divine realm', the supreme image of the glorified redeemer on earth, with power 'not only to rule . . . by his wisdom, and to conduct this holy Realm by [his] authority . . . it is also for [him] to create Ministers and Officers of [his] Realm'. ${ }^{70}$

This potent vision of episcopal supremacy was again evoked in the Traité des saints ordres: the priest represented Jesus Christ as absolute king in his Resurrection: the bishop represented him as 'perfect king in his Ascension'.$^{71}$ It is noteworthy that Olier chose the appellation 'king' to describe the status of the bishop, as he was the only member of the French school to do so during this era. His choice probably reflects the growth of the absolutist mentality within France by the mid-seventeenth century; in adopting the title 'absolute king', Olier could not have been unaware of its strong connotations of unrivalled leadership and government. His use of the term is almost certainly significant too, if we recall that he presented the 'Projet' during the Fronde, when the authority of the young Louis XIV was severely challenged by a temporary alliance of parlementaires, the nobility and common people. ${ }^{72}$ Indeed, like most 
of his contemporaries in France, Olier was always a firm supporter of monarchical government in the secular realm as well as in the spiritual. ${ }^{73}$ In any case, his use of 'absolute' and 'perfect' suggests an all-encompassing power of government and de facto jurisdiction on the part of the bishop through personal actions and through delegation of ministers deemed suitable by him. It is clear, therefore, that he wished to attribute far-ranging and thorough powers of jurisdiction to the episcopate and, in so doing, to stress the bishops' position at the summit of the ecclesiastical hierarchy. The order of priests that he founded was premised on the principle of complete obedience to bishops in ecclesiastical activities, like the Oratorians, the Eudists and the Lazarists founded by Vincent de Paul (1581-1660). Olier consistently emphasised this fact in his relations with individual prelates, even removing Coudere, the superior of the Lodève seminary, in 1649 at the request of Bishop François Bosquet. Unfortunately, the correspondence does not reveal why though it appeared that Bosquet had lost confidence in his managerial abilities. In any case, Olier's letter to the bishop was couched in terms of the utmost reverence and obedience for, he wrote, the bishops of France could 'call and dismiss us when they want . . . We must not violate the respect due to them.' ${ }^{74}$

Olier's submission to Bosquet's episcopal authority and his veneration of the bishop's episcopal status cannot have gone unnoticed by that particular prelate, and, as the century progressed, it is clear that the ideas of Bérulle and his disciples filtered into the ranks of the French episcopate. Indeed, their views came to have an impact on the type of men appointed to sees as well as on the outlook of bishops themselves. There were two ways in which reformers passed their ideas to the episcopate: through published writings, as has been seen, and through personal interaction. As for the second means, we have already noted the close links between Bérulle and La Mothe-Houdancourt, Eudes and Auvry, between Olier and Caulet, Tronson and Fénelon. All the major reformers were in direct and regular contact with bishops and did not hesitate to harness these connections to counsel them on the duties and character of their office. So Bérulle advised Philippe Cospeau, a fellow dévot and a bishop renowned for his virtue and learning, ${ }^{75}$ and also operated as a strong influence on Jean-Pierre Camus, bishop of Belley. The views that Camus expressed in his numerous publications, of which more will be said at later points, were heavily Bérullian, and concentrated, therefore, on the elevated rank of bishops within the ecclesiastical hierarchy and on the authority that they held over the clergy of their dioceses. Camus also stressed the perfecting role of prelates, carried out through a combination of preaching, sacramental administration and virtuous example. ${ }^{76}$ It was Condren who persuaded Sébastien Zamet not to resign his bishopric when the bishop had a vocational crisis during the 1630s; in fact, 
Zamet respected Condren to such a degree that he wished to join the Oratorians. Condren, however, advised him to remain faithful to his first vocation by serving the souls that Christ had committed to him. He could cultivate the strength do achieve this task through annual retreats, wrote Condren, just as Jesus had retired in solitude to pray to his Father. ${ }^{77}$ Olier too made sure that his views were communicated to French bishops: writing to one bishop in 1651, at the same time that he presented his 'Projet' to the episcopate, he pledged the Sulpicians' obedience to the 'saintly . . . [and] holy prelates' of the church. ${ }^{78}$ Writ of the specifically episcopal spirit upon which he had elaborated in his 'Projet' and, in fact, almost paraphrasing this text, he told the bishop of Viviers that 'the spirit with which God filled your person had to be their [Sulpicians'] life and virtue . . . Your spirit will animate them and render them capable of all that [is] most important and useful to the diocese. ${ }^{79}$

Leading reformers also adeptly harnessed their network of connections with the monarchy and its officials to sway the process of episcopal appointments, under royal control since the 1516 Concordat. Certainly the crown sometimes sought their advice, though they were not averse to offering their unsolicited opinions, especially when the crown looked like using bishoprics as political rewards. Before his split, in the late 1620 s, with Richelieu over the minister's willingness to subordinate the interests of catholicism to those of the state, ${ }^{80}$ Bérulle suggested candidates to him whom he considered to possess the necessary qualities for elevation to the episcopate. He believed Bernard Despruets to be ideal for Lyon when Charles Miron was thought to be dying: a candidate who would be a responsible and energetic pastor, who was virtuous, learned and a good preacher. ${ }^{81}$ Other reformers also encouraged the crown to choose individuals who approximated to this vision. The letters of both Charles de Condren and Jean Eudes contained similar instances of advice to the monarchy, urging that suitable prelates be appointed. When Condren succeeded Bérulle as Oratorian superior, Richelieu adopted his services, frequently requesting his frank opinion of possible episcopal candidates. This was naturally the kind of demand with which the reformers were only too happy to comply, and Condren was, as a result, able to ensure that Hugues Labatut, an ecclesiastic of his choice, succeeded Barthélemy de Donadieu in Comminges. To sway the crown's decision, he praised Labatut's vigour, strength, learning and piety, and presented him as the ideal choice because of his long experience of diocesan administration as Donadieu's vicar. Shortly after Condren wrote his letter to Richelieu, Labatut was appointed bishop of Comminges and was ultimately consecrated in $1640 .{ }^{82}$ Eudes too proposed the above qualities as essential to bishops, informing Anne of Austria that the only way to restore the church to its 'first splendour' was to promote good bishops. Only the truly holy should be appointed to such an important office, he emphasised, since the 'health of souls' depended on them. ${ }^{83}$ 
It was in this sphere of the dissemination of ideas that Vincent de Paul was a central figure. As the founder of the Lazarist priests and a protégé of Bérulle, a member of the Conseil de Conscience and a close associate of a remarkable number of bishops, he provided an essential link in the transmission of ideas on episcopacy, channelling the reform school's vision to current and future bishops and priests. Like his sacerdotal beliefs, his notion of episcopacy was not original, being a combination of the dominant influences of the century: a mix of Bérullian concepts of hierarchy, mystical annihilation of the self in order to attain total receptivity to the divine will, and the desire to cultivate a 'sanctified' clergy, attuned to the character of their vocation. He too stressed the authority of bishops over priests and expected members of his own Congregation to obey their wishes within dioceses. ${ }^{84}$ After he established the Congregation of the Mission in 1625 it immediately became a powerhouse of clerical reform, and rapidly involved itself in the administration of seminaries; by the time de Paul died in 1660, its priests controlled fourteen of these. ${ }^{85}$

Because de Paul's theology was not original in itself, his contribution to the development of episcopal ideology has not been afforded a separate analysis here, but this in no way detracts from his prominence within the history of Catholic reform in seventeenth-century France or indeed from his role in the evolution of episcopal ideals. From a far lower social background than men like Bérulle and Olier, de Paul did not have natural access to the monarchy's powerbrokers. Yet through a combination of humility and canny networking he succeeded in earning the admiration and patronage of the cream of French society, including Madame de Gondi, Richelieu, Anne of Austria and, temporarily, Mazarin. These contacts opened doors for the reformer, and certainly helped in his elevation to a seat in the royal Conseil de Conscience. This was a rather loosely defined body, initially meeting in 1643, when de Paul joined it, and then becoming a fixture of government into Louis XIV's mature reign. Among the chief functions which came under its remit of 'ecclesiastical affairs' was the appointment of bishops. De Paul's access to this particular corridor of power for nine years offered him the perfect opportunity to press home his episcopal ideal. As a result, he was influential in the promotion to sees of several ecclesiastics with whom he was in contact and whom he considered to fulfil the reformers' criteria: men like Caulet, Nicolas Pavillon, Philibert de Brandon, François Perrochel and Nicolas Sévin. Moreover, Bishops Philippe Cospeau and Augustin Potier were both early members of the Conseil too, and were extremely close to the main French clerical reformers. ${ }^{86}$

De Paul assiduously cultivated his links with the episcopal circle and used these relationships to spread the reformers' views of the episcopal office. His closest friendship was with Bishop Alain de Solminihac, and it was a source of 
constant correspondence, mutual support and fruitful advice for both men for almost thirty years. De Paul persuaded an ageing Solminihac against resigning his diocese in 1652 when the bishop was struck down with an illness that sapped his formerly inexhaustible energy. The Apostles and Saint Paul had retained their charges despite great sufferings, he wrote to Solminihac, and so, therefore, should their successors. ${ }^{87}$ These two churchmen also discussed current local, national and international ecclesiastical affairs, and exchanged information on persons and events, not least on the suitability of particular individuals for episcopal promotion. Solminihac's relations with de Paul, Olier and other dévots meant that he shared their ideas about the sort of 'apostolic men' who should be raised to the episcopate. De Paul worked tirelessly, and with some success, to ensure that such worthy appointments were made. His image of the good bishop was most clearly presented in his praise of prelates like Solminihac, Perrochel, Brandon, Augustin Potier and François Fouquet, all of whom he regarded not only as pious and virtuous but as excellent administrators and teachers who strove to draw the faithful towards salvation. In order to encourage other prelates, de Paul did not hesitate to use them as examples worthy of emulation, citing, for instance, Fouquet and Barthélemy de Donadieu to Louis Abelly, then vicar-general of Bayonne, as 'true bishops' ${ }^{88}$

Vincent de Paul was also a close associate of Nicolas Pavillon and Étienne Caulet during the 1640 s and 1650s, though their relations cooled as both bishops drew close to the Jansenist camp in the late 1650s. From 1633, de Paul initiated a regular series of conférences des mardis at Saint-Lazare, attended by a long line of priests who were to become model bishops in later decades, including Antoine Godeau, Felix Vialart, Pavillon, Fouquet and Perrochel. ${ }^{89}$ It was de Paul who persuaded Nicolas Pavillon to accept his nomination to Alet in the late 1630s, demonstrating the close relationship between the two and Pavillon's regard for de Paul's advice. ${ }^{90}$ The conferences provided a forum for a subject dear to de Paul, the implementation of clerical reform, so that their emphasis lay on producing priests who recognised the sanctity of their vocation and who were able to live accordingly. Here, ordinands and priests discussed theological questions as well as learning about the practicalities of pastoral administration, methods of prayer, meditation and study. Equally, the conferences were the perfect opportunity to stress the hierarchical dignity and authority of bishops. De Paul utilised them actively to promote respect for prelates and to encourage awareness of the perfection and responsibilities of the episcopal office. At one conference, probably attended by Étienne Caulet, he used Alain de Solminihac's generosity to the Lazarist missionaries under his care as an example of perfect episcopal charity: de Paul's missionaries had written appreciatively of the corporal and spiritual 'refreshment' that they had received from the bishop when they stayed with him in Cahors. De Paul's 'good conference' 
on the subject provides an important instance of the presentation of a contemporary bishop as a model for future prelates to follow. ${ }^{91}$

Through the seventeenth century, French clerical reformers produced important contributions to the related issues of the nature and functions of episcopacy and the character of French episcopal reform. From the widely held belief that the church was a hierarchy of ecclesiastical orders, they managed to formulate a unique theology which both upheld and enhanced that typical assumption. Because of their preoccupation with clerical sanctification, they principally concentrated on the hierarchical authority of bishops, and it was as a function of this that they treated the perfection of the episcopal state, its power to perfect and its obligation of personal sanctity. With the thought of Jean-Jacques Olier, however, the considerations of the priesthood school were brought to maturity. Olier continued to stress the supreme dignity and authority of the episcopal office. However, he advanced Bérullian theory by explicitly confirming the existence of a unique episcopal spirit upon which priests and laity were dependent for sanctification. In doing so, he firmly asserted the necessity of bishops within the church in order for it to function effectively and verified that episcopal distinctiveness was not solely a result of bishops' jurisdictional powers and obligation of supreme personal holiness. Additionally, his emphasis on the vivifying and nurturing qualities of bishops and their personal virtues introduced a fuller conception of episcopacy, drawing reflection far beyond obedience and discipline and granting it a more positive and pastoral tone. Again, Bérulle laid the foundations for this by noting the mediatory and perfecting qualities of bishops, but it was Olier who carried the process to conclusion. Ultimately, a definite and sophisticated image of episcopacy emerged within the circle of French clerical reformers, culminating in the thought of Olier: that of a strong, zealous and saintly episcopate, enlightened through intimacy with God, functioning with supreme, but benign, authority over the lower clergy and the faithful, and imparting a unique sanctifying grace to them to ensure their salvific union with God. With such emphatic and distinctive views, it is obvious why the reformers did not intend to remain isolated in theological contemplation. Instead, through intervention in the process of episcopal appointments and through instruction and advice to prelates and potential prelates, they actively sought to secure the appointment of bishops who would be fully aware of this image and who would strive to embody its characteristics.

Notes

1 Dagens, Bérulle; Dupuy, Bérulle et sacerdoce; Krumenacker, L'Ecole; Lemaître, 'Prêtre'; Walsh, 'Priesthood'.

2 Bergin, Episcopate, pp. 513-17; Blet, 'Vincent'; Broutin, Réforme, ii, pp. 252-7; Taveneaux, Catholicisme, i, pp. 111-13. 
3 Dictionnaire de spiritualité, 17 vols (Paris 1937-95), xi, col. 849.

4 Charles de Condren, Oeuvres complètes du P. Charles de Condren, ed. Louis-Marie Pin, 2 vols (Paris 1857-58); François Bourgoing, Exercices d'une retraite spirituelle de dix jours (Paris 1648).

5 Pierre de Bérulle, Oeuvres complètes de Bérulle, cardinal de l'église romaine (Paris 1644).

6 Dagens, Bérulle, p. 132.

7 Henri Brémond, Histoire littéraire du sentiment religieux en France depuis la fin des guerres de religion jusqu'à nos jours, 12 vols (Paris 1916-36), ii, pp. 193-262. Dated, though still valuable, biographies exist for two members of the circle, Barbe Acarie and Benoît de Canfield: Lancelot Sheppard, Barbe Acarie, Wife and Mystic. A Biography (London 1953); Optatus van Veghel, Benoît de Canfield (1562-1610), sa vie, sa doctrine et son influence (Rome 1949).

8 Philip Benedict, Rouen during the Wars of Religion (Cambridge 1981), p. 196; Denis Richet 'Sociocultural Aspects of Religious Conflicts during the Second Half of the Sixteenth Century', in Robert Forster and Orest Ranum (eds), Ritual, Religion and the Sacred (Baltimore 1982), p. 204.

9 This belief persisted despite the suspicions voiced by Erasmus, Cajetan and others. PseudoDionysius was in fact a sixth-century Syrian writer who adopted the pseudonym of Denis the Areopagite, Paul's companion in Acts 17:34. For the prevelance of Pseudo-Dionysian theology in medieval and early modern thought, see Wayne Hankey, 'Dionysian Hierarchy in St. Thomas Aquinas. Tradition and Transformation', in Ysabel de Andia (ed.), Denys l'Aréopagite et sa postérité en Orient et en Occident. Actes du Colloque International Paris, 21-24 septembre 1994 (Paris 1997), pp. 405-38, and Wayne Hankey, 'Augustinian Immediacy and Dionysian Mediation in John Colet, Edmund Spenser, Richard Hooker and the Cardinal de Bérulle', in Dominique de Courcelles (ed.), Augustinus in der Neuzeit. Colloque de la Herzog August Bibliothek de Wolfenbüttel, 14-17 octobre, 1996 (Turnhout 1998), pp. 125-60.

10 Dagens, Bérulle, pp. 118-32; Krumenacker, L’Ecole, pp. 113-18.

11 Dagens, Bérulle, p. 141; Hankey, 'Immediacy'.

12 The 'Projet de l'érection de la Congrégation de l'Oratoire de Jésus' is contained in Béreulle, Correspondance, i, p. 118.

13 Pseudo-Dionysius developed his teaching in the treatises The Divine Names, The Mystical Theology, The Celestial Hierarchy and The Ecclesiastical Hierarchy. For the purpose of this study I have used the following edition: Pseudo-Dionysius, Pseudo-Dionysius. The Complete Works, trans. Colm Luibheid (New York 1987).

14 Ibid., pp. 160-74, 201-35.

15 Pierre de Bérulle, Oeuvres complètes du cardinal de Bérulle, ed. Jacques-Paul Migne (Paris 1856), col. 1271.

16 Cochois, 'Bérulle' (1961), 327.

17 Bérulle, Oeuvres, ed. Migne, col. 1270. See Louis Tronson's identical teaching in one of his regular letters to the bishop of Limoges: Raymond Darricau, 'La Correspondance de Louis de Lascaris d'Urfé, évêque de Limoges (1676-1696) et de M. Tronson, supérieur général de Saint-Sulpice', Le Limousin au xviie siècle. Littèrature, histoire, histoire religieuse. Colloque pluridisciplinaire Limoges, 9-10 octobre 1976 (Limoges 1979), p. 208.

18 Bérulle, Oeuvres, ed. Migne, col. 286.

19 Charles Williams, The French Oratorians and Absolutism, 1611-1641 (New York 1989), pp. 121-9.

20 Charles de Condren, L'Idée du sacerdoce et du sacrifice de Jesus-Christ donnée par le R. P. de Condren second superior general de l'Oratoire de Jesus avec quelques eclaircissements et une explication des prieres de la messe par un prêtre de l'Oratoire (Paris 1677), p. 106.

21 Bérulle, Oeuvres, ed. Migne, col. 1270: 'L'état de prêtrise . . . est un office divin en son usage et ministère . . . l'origine de toute la sainteté . . . en l'Église.'

22 Ibid., col. 826.

23 Condren, Sacerdoce, pp. 135-8.

24 Bérulle, Correspondance, iii, pp. 617-18, Bérulle to a priest of the Oratory (n.d.). 
25 Edmund Richer, Libellus de ecclesiastica et politica potestate (Paris 1611).

26 Richer's doctrines are discussed in Ch. 3.

27 Bérulle, Correspondance, i, p. 118: 'Celle-ci serait jonte aux prélats par le voeu d'obéissance, quant à l'exercice et emploi des fonctions ecclésiastiques.'

28 Charles de Condren, Lettres du père Charles de Condren (1588-1641), ed. Paul Auvray and André Jouffrey (Paris 1943), p. 148; Williams, Oratorians, pp. 134-5.

29 Bérulle, Correspondance, iii, p. 413; Bérulle, Oeuvres, ed. Migne, col. 607.

30 Cochois, 'Bérulle' (1961), 348.

31 Pseudo-Dionysius, Complete Works trans. Luibheid, pp. 236-8. Bishops retained powers of purification and illumination in addition to that of perfection, but the latter was their chief activity.

32 Cochois, 'Bérulle', 358-9; Vincent de Paul, Saint Vincent de Paul. Correspondance, entretiens, documents, ed. Pierre Coste, 14 vols (Paris 1920-25), ii, p. 3, Vincent de Paul to Louis Abelly, 14 January 1640.

33 Bérulle, Correspondance, iii, p. 308, letter to La Mothe-Houdancourt (n.d.). La MotheHoudancourt was appointed bishop of Mende in 1624.

34 Ibid., p. 636, letter to an unnamed bishop (n.d.).

35 Quoted by Cochois, 'Bérulle' (1962), 370: 'Ils doivent tendre vers la Splendeur divine ellemême et garder les yeux fixés sur elle, comme il sied à leur caractère sacré'; Louis Tronson, Correspondance de M. Louis Tronson, troisième supérieur général de la Compagnie de Saint-Sulpice, 3 vols (Paris 1900), ii, p. 416, Tronson to Lascaris d'Urfé, 20 August 1678.

36 Bérulle, Oeuvres, ed. Migne, col. 813.

37 Cochois, 'Bérulle' (1961), 371.

38 Bérulle, Correspondance, iii, pp. 346-7, letter to Cardinal Richelieu, 3 December 1627. Despruets was not appointed bishop of Saintes. He became bishop of Saint-Papoul in 1636: Bergin, Episcopate, pp. 607-8.

39 Similarly, Condren advised Sebastien Zamet to give himself in his episcopal work 'au Fils de Dieu qui vous y appelle, et y travailler ainsi avec lui': Condren, Lettres, p. 152.

40 Pioger, Orateur, p. 436.

41 Eudes founded seminaries at Caen (1643), Coutances (1650), Lisieux (1653), Rouen (1658), Evreux (1667) and Rennes (1670), with the encouragement of the incumbent prelates: Jean Eudes, Oeuvres complètes du bienheureux Jean Eudes, 11 vols (Paris and Vannes 1905-9), iii, preface (unpaginated).

42 Eudes's published writings include Advertissements aux confesseurs missionnaires (Caen 1644), Le Bon Confesseur (Paris 1666), Manuel pour une communauté d'ecclésiastiques (Caen 1668), Le Mémorial de la vie ecclésiastique (Lisieux 1681) and Le Prédicateur apostolique (Caen 1685). He also composed 'Traité de l'office divin' and 'Saint sacrifice de la messe' but neither of these was printed and no manuscript copies remain.

43 Eudes, Oeuvres, iii, preface (unpaginated).

44 Ibid., pp. 12, 17.

45 Ibid., xi, p. 66, letter to François II de Harlay de Champvallon (c. 1655).

46 Ibid., iii, pp. 17-18.

47 Ibid., xi, pp. 75-6, letter to Claude Auvry, 1 June 1659. Auvry was not in fact appointed to Bayeux.

48 Ibid., p. 53, letter to the queen mother, 2 September 1648.

49 Faillon, Olier, i, p. 135.

50 This brought new pressures, which remain outside this study's chronological scope. As more aristocratic ordinands resided in the seminary, the austere disciplinary regimes implemented under Olier, Bretonvilliers and Tronson became more difficult to preserve: McManners, Church, i, pp. 230-1.

51 Jean-Jacques Olier, Lettres spirituelles de M. Olier, ed. Louis Tronson (Paris 1672); JeanJacques Olier, Traité des saints ordres, ed. Gilles Chaillot, Paul Cochois and Irénée Noye (Paris 1984). 
52 Tronson's Manuel du séminariste and Traité de l'obeissance became standard reading material in Sulpician seminaries. They are printed in Louis Tronson, Oeuvres completes de M. Tronson, ed. Jacques-Paul Migne, 2 vols (Paris 1857), i, cols 301-47, 349-562.

53 Lascaris kept Tronson's epistolary counsels close to hand, by keeping a summary of his teaching in his personal copy of the New Testament: Tronson, Correspondance, ii, pp. 439-40.

54 François de Salignac de La Mothe-Fénelon, Correspondance de Fénelon, ed. Jean Orcibal, Jacques Le Brun and Irénée Noye, 17 vols (Geneva 1972-99), xii, p. 226, letter to François Leschassier, 22 March 1706: 'Quoique je n'aie jamais vu M. Olier, je n'ai rien ouï dire de sa conduite et de ses maximes, qui ne m'ait fait une profonde impression.' See also vol. ii, pp. 9, 48, 128, and see vol. i, pp. 143-50, for a summary of Fénelon's frequent meetings with Tronson during the 1670s and his links with the Saint-Sulpice seminary.

55 Olier, Traité, pp. 183-98. Tellingly, Olier entitled this chapter 'De la suprême dignité du sacerdoce'.

56 Ibid., pp. 223-5.

57 Jean-Jacques Olier, 'Projet de l'établissement d'un séminaire dans un diocèse' (1651). A copy of this is printed in Faillon, Olier, iii, pp. 551-78.

58 Olier's Traité and his letters are also useful indicators of his episcopal thought. In particular, see his letters from the late 1640s to Étienne Caulet, bishop of Pamiers: Jean-Jacques Olier, Quatre lettres inédites de M. Olier, ed. Louis Blazy (Foix 1931).

59 Jean-Jacques Olier, Lettres de M. Olier, 2 vols (Paris 1885) i, pp. 555-6.

60 Olier, 'Projet', in Faillon, Olier, iii, p. 571.

$61 \mathrm{Ibid}$, p. 554: 'On voit les principaux ministres des Évêques, qui sont les Prêtres, vivre sans dépendance de leurs chefs, n'ayant aucun respect pour leur sacrée direction ni attache à leur obéissance.'

62 Ibid., p. 562.

63 In Sulpician seminaries, the superiors were understood by Olier to operate as agents of the diocesan bishop: ibid., p. 556.

641 Tim. 5:4-5; A Select Library, trans. Lett Feltoe, xii, pp. 9-71.

65 Olier, 'Projet', in Faillon, Olier, iii, p. 573: 'Dieu leur en done la tendresse pour caresser leurs enfants, la douceur pour les souffrir en leur infirmité, la force pour les porter en leur faiblesse, la sagesse pour les reprendre en leurs défauts, la lumière pour les éclairer en leurs ténèbres, la joie pour les consoler en leurs afflictions.'

66 Olier, Quatre, p. 14, letter to Caulet, January 1648: 'n'y ayant rien de l'authorité et drois pontificaus qui soit si fort interesse que la voye de douceur et de clemence ne prevaille. Leur temoignant ... que vous pourriez en user autrement sur le tort . . . mais que les entrailles de Père et la Charité d'un epous ne vous le permettent pas en ce rencontre.'

67 Olier, Lettres de M. Olier, ii, p. 520, Olier to an unnamed correspondent (n.d.).

68 Olier, 'Projet', in Faillon, Olier, iii, pp. 574-5: 'cette grâce capitale et cet esprit de chef . . . doit écouler du chef dans les membres par ses jointures naturelles et par ses ligaments, ses veines et ses nerfs préparés à la distribution des esprits et à la communication de sa vie. La grace qui ne se répandra pas du chef dans ses membres . . . n'animera jamais qu'à demi tous les membres sacrés de ce corps.'

69 Olier, Quatre, p. 11, letter to Caulet, 29 December 1646: '[Les prêtres] sont autant de signes de la vie de l'esprit et de l'onction qui habite dans [l'évêque] et qu'il reprend hors de luy même ... l'esprit du saint prelat dessert la sanctification dans les peuples.'

70 Olier, 'Projet', in Faillon, Olier, iii, p. 577: 'C'est à eux qu'il appartient, non seulement de régler . . . par leur sagesse, et de conduire ce saint Royaume par leur autorité . . . c'est encore à eux à créer les Ministres et les Officiers de leur Royaume.'

71 Oliver, Traité, pp. 27-8.

72 On the Fronde, see Geoffrey Treasure, Mazarin. The Crisis of Absolutism in France (London 1995), pp. 103-229. See also Orest Ranum, The Fronde. A French Revolution, 1648-1652 (New York and London 1993). Robert Knecht, The Fronde (London 1975), offers a general overview and analysis of events. 
73 Paul Klevgard, 'Society and Politics in Counter-Reformation France. A Study of Bérulle, Vincent de Paul, Olier and Bossuet' (PhD dissertation, Northwestern University, Illinois 1971), p. 168.

74 Faillon, Olier, iii, pp. 259-63.

75 Émile Jacques, Philippe Cospeau, un ami-ennemi de Richelieu 1571-1646 (Paris 1989), p. 63.

76 Jean-Pierre Camus, De l'unite de la hiérarchie (Douai 1634); Jean-Pierre Camus, Considérations hiérarchiques (Paris 1642); Jean-Pierre Camus, Hiérarque.

77 Condren, Lettres, pp. 150-2, letter to Zamet, October 1634.

78 Olier, Lettres de M. Olier, i, pp. 557-8, letter to unnamed prelate, March 1651.

$79 \mathrm{Ibid}$, ii, p. 10, letter to Louis-François La Baume de Suze, 1651: 'L'esprit dont Dieu remplit votre personne devait être leur vie et leur vertu . . . Votre esprit les animera et les rendra capables de tout ce [qui est] plus important et plus utile au diocèse.'

80 The dévot party opposed Richelieu's anti-Habsburg foreign policy, which allied France with Protestant regimes: William Church, Richelieu and Reason of State (Princeton 1972), pp. 201-7; Nannerl O. Keohane, Philosophy and the State in France (Princeton 1980), pp. 191-2.

81 Bérulle, Correspondance, iii, p. 344, letter to Richelieu, 3 December 1627.

82 Condren, Lettres, pp. 227-30, letter to Richelieu, September/October 1637; Bergin, Episcopate, pp. $644-5$.

83 Eudes, Oeuvres, xi, p. 53, letter to queen mother, 2 September 1648; ibid., memoir to same, p. 60 , c. 1648 ; ibid., letter to same, p. $64,1653$.

84 De Paul, Correspondance, i, p. 112, letter to François Du Coudray, 1631; ibid., iv, p. 166, letter to Philibert de Brandon (bishop of Périgueux), 1 April 1651; ibid., p. 314, letter to Balthazar Grangier de Liverdis (bishop of Tréguier), 28 January 1652.

85 One hundred years later, the order managed one third (sixty) of France's diocesan seminaries. The Eudists ran thirteen, the Oratorians fourteen and the Sulpicians twenty: McManners, Church, i, p. 201.

86 Blet, 'Vincent'.

87 Solminihac, Lettres, p. 470, de Paul to Solminihac, 1651 or 1652.

88 De Paul, Correspondance, ii, pp. 2-3, letter to Louis Abelly, 14 January 1640 . Abelly was nominated bishop of Rodez in 1662, but he was forced to abandon his appointment when struck with paralysis in 1665 .

89 Ibid., i, p. 413, letter to Jean de Fonteneil, 8 January 1638; Blet, 'Vincent', 104-9.

90 De Paul, Correspondance, i, 413n, letter to Jean de Fonteneil, 8 January 1638.

91 Ibid., p. 207, letter to Solminihac, 23 August 1633. 


\section{3 \\ Lower clergy versus bishops}

The church desperately needed men like Bérulle and Olier to formulate coherent theologies to underpin its reform initiatives. Yet not everyone agreed that the church should function according to a hierarchical arrangement that gave bishops absolute authority over the clergy below them in rank. Fundamental disagreements over the complicated questions of hierarchy and jurisdiction brought many tough challenges for French bishops, for they were pitted against members of the lower clergy and even against the might of the papacy as they sought to implement their vision of Tridentine discipline. Because the issues at stake were fundamental to the future shape of the church and to the power of bishops within it the quarrels assumed broad importance for all of the parties involved; they were never simply petty squabbles over, for instance, the simultaneous celebration of masses in regular and parish churches on feast days. Instead, as this chapter and the next one will explain, they encapsulated the much larger dilemma of the loci of ecclesiastical power, and their outcomes had profound implications for the chain of ecclesiastical government at every level of the Catholic church. Virtually every recent study of individual bishops and dioceses in France has catalogued instances of these recurrent disputes ${ }^{1}$ but, despite their collective importance, little effort has been made to place them within their national and international contexts, or to assess their accumulative impact on the French episcopate itself. Yet in studying the development of episcopal ideologies, it is hardly sufficient simply to treat particular squabbles within the confines of diocesan boundaries. Nor is it enough to present the lower clergy's views of episcopacy without reference to that of bishops themselves, for the episcopate's beliefs both influenced, and were themselves deeply scored by, the ideas and actions of non-episcopal ecclesiastics.

Of course, the episcopate's steps to combat the lower clergy's hostility were occasionally tinged with a degree of formalism. Bishops knew that they might well need to cultivate goodwill among regulars and curés if they were to implement diocesan reforms in the future. It was sensible, therefore, to 
resolve disputes with a demonstration of episcopal supremacy, but to cloak it with words and gestures of reconciliation if possible. Yet even when particular incidents might appear to have a whiff of posturing farce about them, that should not obscure the fact that they were taken very seriously by all those involved. The episcopate's often extended responses to its opponents were overwhelmingly driven by the belief that all challenges to its position had to be quashed if it was to avoid the establishment of precedents that would later return to haunt it. For bishops, as for the lower clergy, there were essential interests at stake, and they displayed steely resolve in opposing the 'enterprises' that ruined their power. As Antoine Godeau observed, 'We cannot suffer the diminution [of episcopal power] without being more culpable than those who make the mistake.'2

Theological and jurisdictional conflicts concerning the lower clergy had a long pedigree in France. From the thirteenth century, the regulars had been plagued by accusations that they enticed the faithful away from the parishes, leaving the curés short of both income and pastoral work. The French church had become a centre for the debate when the Franciscans had begun to argue that the mendicant orders possessed greater mandates to preach and administer the sacraments than the parish clergy. In 1409, the Franciscan pope, Alexander V, even issued a bull (Regnans in excelsis), affirming that the regulars held privileges to perform these services. ${ }^{3}$ As the religious orders underwent their rapid revival during the Catholic Reformation, this old quarrel erupted with renewed vigour. In France, the orders grew tremendously during the early seventeenth century: the reformed Carmelites arrived in 1611 and quickly scattered houses throughout the provinces, while the Franciscans, Dominicans and Minims proved equally fertile. In Paris alone, fifty-five new religious houses were established between 1600 and 1639. ${ }^{4}$ The Jesuits had been at the vanguard of reform for many decades and, like other orders, had earned considerable independence of action, normally legitimised by papal privileges. As a result, it is not unexpected to find that when French bishops began to make concerted efforts to bring the regulars under tighter control these strongly resisted the challenge to their customary autonomy. The regulars appeared increasingly willing to become involved in disputes with bishops, partly because they were genuinely hopeful of papal support for their claims of privilege. Equally, however, they were goaded towards action by the ever more militant stance of the bishops. To some extent, regulars believed themselves forced to defend their territories of pastoral care since the attitudes and actions of bishops seemed to impinge ever further upon their ground. But, in turn, when confronted by the regulars' opposition to their policies, French bishops simply tended to harden their own stance in order to overcome resistance; their convictions were forged and reinforced by opposition. 
It was not only the regulars who troubled episcopal discipline during this period. Among the secular clergy, the parish curés shared a spirit of independence that is most commonly designated as Richerism, after its most famous advocate, Edmond Richer, a canonist and syndic of the Sorbonne. In his Libellus, ${ }^{5}$ Richer argued that curés should share in the government of the church at both diocesan and higher levels, and he was duly censured by the Paris Faculty and the provincial synods of Aix and Sens in 1612. ${ }^{6}$ Periodically, local curés displayed a similarly startling tendency to unyoke themselves from episcopal supervision and to direct church government, generally justifying their actions by accusations of episcopal despotism or neglect, and constructing detailed arguments to defend their freedom. Bishops and parish priests usually fought side-by-side against the regulars, for it was not in the interest of either to allow regulars unrestricted access to the parish faithful. Even so, they did not necessarily enjoy a harmonious relationship. Historians are familiar with the militant 'spirit of revolt' among parish priests in the eighteenth century, ${ }^{7}$ but its roots lay deep in the seventeenth century when many discontented curés struggled, unsuccessfully, with bishops to assert their autonomy and influence in government. More than one bishop experienced that particular trial: Bishop Solminihac of Cahors was even forced to face down a rival who tried to issue letters of approbation to would-be curates and was horrified when his diocesan synod was interrupted by a riot of clergy dissatisfied with 'tyranny' and 'oppression'. 8

Local disputes flared too when bishops attempted, in the name of reform, to impose tighter controls on diocesan chapters, only some of which were composed of regular canons. These quarrels, though not tending to assume national significance, exacerbated bishops' sensitivities towards their authority. Several prelates found themselves embroiled in quarrels with their cathedral chapters, the members of which resented any suggestion that they might be subject to the jurisdiction of the local bishop. One of the most spectacular clashes occurred in 1602 when Archbishop François de Sourdis was subjected to physical attack by the canons of his cathedral chapter after he had attempted to demolish a side altar in Bordeaux Cathedral on the grounds that members of the congregation had persistently been permitted to sit or stand on it during services. In this particular case, the canons justified their resistance to the bishop's jurisdiction by pointing to a papal bull of 1458 which, they claimed, exempted them from episcopal jurisdiction. When the bishops' masons arrived to dispose of the altar, the canons imprisoned them in the cathedral until Sourdis, in a grand gesture of episcopal authority, swept into the church, denounced the canons, released the masons and personally oversaw the altar's destruction. ${ }^{9}$

This episode was unusual, however, for two reasons. In the first place, the chapter pointed to a papal privilege, as religious orders such as the Dominicans and Jesuits would also do, to extricate themselves from episcopal supervision. 
In most other disputes, chapters justified their independence from bishops on the basis of traditional local customs that had evolved through the centuries. The Bordeaux clash also deviated from other quarrels by the fact that it assumed national significance, even moving Henri IV to criticise Sourdis's undoubtedly provocative actions. ${ }^{10}$ But most arguments between bishops and their chapters arose over questions of precedence and protocol, and they usually remained local and focused on regional customs. These episodes could sour relations between canons and bishops for decades, as occurred in Nîmes, where several disagreements blew up over finances and protocol, and where successive bishops maintained decidedly frosty connections with the cathedral chapter. ${ }^{11}$ This long dispute initially arose in 1609, when the chapter refused to pay Bishop Valernod's prebend, on the basis that it had not done so under his predecessor. One year later, the bishop forbade the chapter to hold its general meeting in his absence. When it ignored his order, he annulled the meeting's decisions and replaced the chapter's newly elected officers with those of his own choosing. Valernod's successors encountered the same troubles, and Jacques Desclaux had similar wrangles in Dax during the 1640s, when his chapter quibbled over the wording of titles, salaries and honours. Only arbitration by the neighbouring bishops of Aire and Bazas broke the resulting stalemate. ${ }^{12}$ Yet although these problems could certainly affect the progress of reform within dioceses, they did not reach the national stage and they certainly did not raise the broader question of the pope's power over bishops and dioceses. It would take the regular-episcopal quarrels to achieve both of these. Unquestionably, however, they hardened the attitudes of those bishops who became embroiled in them, and exacerbated their feeling that episcopal authority had to be defended against the threats that appeared to be closing from chapters, regulars, curés and the papacy.

What weapons did bishops have at their disposal to battle the lower clergy's challenges to their authority? Potentially, they could draw on several: they could patronise publications which struck at the most dangerous claims of their opposition and, like Jean-Pierre Camus, they could even compose vindications of their conduct; they might harness the Assembly's channels to effect powerfully worded legislation upholding their position; they might seek Roman endorsement of those rulings; they could assume immovable opposition to clerical independence within their dioceses. In practice, they chose to adopt each of these methods in deft, and often devastating, combination and, indeed, they certainly felt the need to do so. Many bishops fought to bring independentminded lower clergy under their effective jurisdiction, and the resulting disputes frequently catapulted protagonists on to the national, and even the international, stage through pamphlet wars and via the Assembly of Clergy. But these struggles for the control of religious practices within dioceses meant that 
it was by no means a foregone conclusion that the bishops would succeed in stamping their authority on diocesan ecclesiastical structures and personnel.

Central to these contests were the decrees of the Council of Trent. Its delegates recognised that the religious orders had, over generations, built up a formidable autonomy through privileges which exempted them from episcopal jurisdiction. Equally, they anticipated that their proposed system of hierarchical government would have difficulty accommodating thousands of autonomous religious across Europe. To avoid unedifying clashes, the Council provided a codified system for the government of religious which gave bishops considerable power over their activities. ${ }^{13}$ Simultaneously, it sought to concentrate religious practice in the parishes, where it could prosper under the watchful eye of the diocesan bishop. The Council confirmed that episcopal approval was necessary in order to hear confession or to preach if one did not hold a benefice. ${ }^{14}$ It also advocated parochial preaching and attendance at mass, the latter 'at least on Sundays and the greater feast days' ${ }^{15}$ To aid bishops, Trent added that priests who did not possess a parochial benefice were subject to episcopal examination and approval, without which they could not confess or preach. However, it did not intend to exclude the religious orders from pastoral activities completely. Its decrees were intended to subject their administration to the supervisory authority of diocesan bishops and, to a lesser extent, of parish curés. Regulars were to act as supplementary aids to parochial clergy, co-operating with them to serve the needs of the laity.

The imposition of these regulations proved a major bone of contention, not least in France. Bishops there occasionally complained about regulars who resisted enclosure, ${ }^{16}$ but it was their pastoral activities which caused the most publicised clashes among French clergy and which produced the most extensive exploration of the nature of episcopal authority and status as well as of the authority and status of secular and regular priests. Even at the Council, the potential for future difficulties had been evident; the Jesuit general, Diego Lainez, had vigorously rejected the idea that an inflexible hierarchy should dominate and determine ecclesiastical activities. In his view, if the Jesuits and other orders were to perform their pastoral calling, they needed to be free to respond to the idiosyncratic demands of local circumstances, rather than tied to unyielding precepts that would inhibit their initiatives. ${ }^{17}$ By all means, the church should have a hierarchy, but the rules composed and implemented by its bishops should be subject to mutation if necessary. This had not been a popular suggestion with the bishops of Trent, for to them its 'missionary' ethos smacked of poor supervision, indiscipline and outright anarchy. ${ }^{18}$ Their French successors would have agreed, but there is more than a little of Lainez's attitude in the arguments voiced by French regulars during the seventeenth century. 
Despite variations of opinion, some common fundamental assumptions characterised the regular argument and were manifested in all their written apologies. These elaborate treatises defended regulars from what they deemed entirely unwarranted attacks on their rights and persons by bishops and curés. In doing so, they presented the motivations inspiring regulars to rebel against their bishops as well as the arguments on which they founded their opposition. Equally valuably, their authors often used the opportunity to focus attention on aspects of episcopacy which were not directly linked to the quarrel at hand. Consequently, these protagonists succeeded in offering quite a comprehensive vision of the episcopal office, though theirs was an ideal that certainly did not meet with universal approval.

To circumnavigate the restrictions that Trent placed on them, regulars claimed privileges, granted by popes, which permitted them to sidestep Tridentine policy. The Council had actually anticipated this strategy when it ordered that all dispensations from its canons should be granted only 'after the most mature deliberation . . . by those to whom that dispensation pertains' ${ }^{19}$ When applied to pastoral activities, 'deliberation' would include the diocesan bishop, so that his consideration would be essential for a privilege to be applied. Through canonical gymnastics it was possible, however, to slip past this barrier, and the regulars did so with relative ease. Specifically, the practices of annual confession and communion raised thorny questions. Session XIII of the Council expressly confirmed the decree of the Fourth Lateran Council, held under Pope Innocent III in 1215, though without repeating the actual decree verbatim. ${ }^{20}$ Reiteration of that decree, however, did not conclusively settle the question of parochial annual confession, since its words were themselves open to interpretation: 'All the faithful of either sex, after they have reached the age of discernment, should individually confess all their sins in a faithful manner to their own priest at least once a year . . . If any persons wish, for good reasons, to confess their sins to another priest let them first ask and obtain the permission of their own priest.' ${ }^{21}$

The phrase 'own priest' had been a point of much discussion among canonists and theologians ever since the Fourth Lateran Council, but Trent did not resolve its ambiguity. Some considered it to mean the parish curé, while for others it designated any priest who possessed, by canonical delegation, a special mission to administer to the faithful. ${ }^{22}$ This uncertainty allowed regulars to question the necessity of parochial confession and even to claim that their privileges permitted them to confess regardless of the wishes of parish clergy and bishops. Furthermore, while more moderate defenders of the rights of regulars admitted the exigency of annual parochial communion, hard-liners claimed that their privileges granted them independence in this as well as in annual confession. ${ }^{23}$ They could do so because here, again, Trent prevaricated, 
merely advocating annual communion, without clearly stating if this was to be in the parish church. ${ }^{24}$ While, therefore, the Council favoured parochial sacramental observance its decrees allowed room for argument and manoeuvre in support of rival claims. Here was the heart of the problem for bishops and regulars: the latter could and did argue that Trent had built provisions for privileges into its decrees and, even where it had not, its regulations did not forbid regulars to undertake pastoral activities.

In 1625, as the relationship between French bishops and regulars became strained almost to breaking point, an anonymous regular writer attempted to calm the situation by publishing a substantial tract on the most convenient means through which to restore peace between bishops, curés and regulars. His discussion provided a meticulous, coherent and reasonably temperate synopsis of the regulars' view of episcopacy and of their own status within the church, and drew on a variety of theological and canonical arguments to communicate its points. For these reasons, it is an indispensable source. Because it avoids polemic Le Pacifique à messieurs les evesques et curez offers an essential counterweight to the uncompromising, and often vitriolic, defences produced by other religious authors, and illustrates that those works which gained notoriety for their justifications of the pastoral activities of regulars were not always representative of regular opinion as a whole..$^{25}$

Pacifique's author starkly warned against the disunity that threatened to overwhelm the French church because of the dissension within its clerical ranks over jurisdiction and privileges. ${ }^{26}$ Each sector of the French clergy must, he insisted, recognise their opponents' merit and their contribution to the church's well-being. ${ }^{27}$ Though clearly a supporter of regular privileges and of papal supremacy over bishops, the author of Pacifique did, however, recognise an authoritative role for prelates, based on their place in the ecclesiastical hierarchy. Superficially, this governmental role differed little from that formulated and disseminated in the thought of the principal members of the French school. Fundamentally, though, it was radically different. The Dionysian schema of ecclesiastical hierarchy was intrinsic to the regulars' understanding of episcopacy and religious life in the church; regulars included themselves in the ecclesiastical hierarchy, either as ordained priests or solely as members of the third division, composed of monastic orders, initiates and catechumens. ${ }^{28}$ Within this construction, they agreed that the status of the episcopal office was superior to that of priests, religious and laity, as its hierarchical rank presupposed. In Pacifique, bishops were granted a number of traditional titles. They were superintendents and overseers guarding against abuses and heresy; ${ }^{29}$ masters, doctors, viceroys, angelic mediators and terrestrial gods in their instruction, through word and example, of God's people in faith and morals. Each appellation emphasised the elevated hierarchical position of bishops and their 
role as governors of the faithful, clerical and lay, under their charge. The episcopal office was thus the summit of priesthood since bishops held jurisdiction over priests while simultaneously possessing the power to ordain. ${ }^{30}$ However, by then drawing the papal-episcopal relationship to the fore, regular authors differentiated their views from those of Bérulle, Olier and their disciples. For regulars, their understanding of the connection between the bishop and the pope was utterly pivotal to their conception of episcopacy, and it governed, equally absolutely, their attitude towards the jurisdictional authority of bishops in dioceses. Understandably, their apologists' primary ambition was not to affirm the dignity of the episcopal office. Their motive in writing was to champion the regular cause in the face of criticism from secular clergy and the episcopate. To do so, they had to expose the precise link between the papacy and the bishops.

Through preaching and confession, regulars helped bishops and curés to 'lead souls to the path of health'. ${ }^{31}$ The regulars' defenders stressed, however, that it was the episcopal power of order that primarily distinguished bishops from priests. This charismatic power to perfect was gained through their consecration as apostolic successors, so that they were permitted to consecrate the true body (that of Jesus Christ), and to ordain and absolve 'the members of his mystical body'. ${ }^{32}$ Yet Trent had distinguished episcopacy by two characteristics, its power of order and its power of jurisdiction. By the latter, bishops acted as the governing guides of the faithful, a function that they were entitled to delegate to collaborators. ${ }^{33}$ The regulars' apologists, however, laid far less emphasis on the jurisdictional distinction of bishops than on their distinction of order. Instead, driven by their desire to protect regular pastoral activities, they stressed papal jurisdictional authority.

This was a masterful strategy. Since the conflict over sacramental and preaching activities was ultimately concerned with the extent of episcopal jurisdiction it made sense for religious to avoid emphasising that particular power. Accordingly, Pacifique's author stated that bishops resembled the Apostles, whom they succeeded, in two ways: in their power of order, and in the fact that 'Bishops have for leader and superior, the pope successor of Saint Peter ... All the Apostles received the keys of the Kingdom of Heaven . . one of the twelve was constituted leader.' He then went on to identify how the contemporary episcopate differed from the Twelve. 'The Apostles [received] episcopal order and jurisdiction, immediately from Our Lord but bishops receive jurisdiction from the popes. ${ }^{34}$ The key characteristic of episcopacy, from the regular viewpoint, was the fact that its jurisdiction was dependent on the pope. $\mathrm{He}$, as Peter's successor and the supreme earthly representative of Jesus, directly mediated jurisdictional powers to bishops. To make this claim was not simply a twist of theology; rather, it created intense implications for the actual 
work of bishops and for their relations with the papacy, the lower clergy and the laity. Its significance had been perfectly obvious to the Tridentine delegates, as their deep anxiety over episcopal residence manifested. ${ }^{35}$ Indeed, it had even become an issue of heated debate in the Anglican church from the late sixteenth century with the growth of Puritanism. ${ }^{36}$

The author of Pacifique urged bishops to be obedient to the pope, relying on the former archbishop of Sens, Jean Davy Du Perron, brother of the late cardinal, to illustrate the authenticity of his plea. Whether or not the opinion ascribed to Du Perron was an accurate rendition of his view is of less importance, for our immediate purpose, than the argument it proposed. In any case, the author aimed to sway undecided bishops towards the sentiments supposedly espoused by the late archbishop. His propaganda presented Du Perron as a pro-regular and pro-papal prelate: he had defended the legitimacy and utility of privileges against those who solicited his support in opposing them on the basis that such hostility was a direct attack on the pope whom Du Perron had always defended. ${ }^{37}$ Although the archbishop had agreed with the assertion that annual parochial communion had been confirmed by a Tridentine decree, he had acknowledged that this was not the case for confession. Within the pages of Pacifique, Du Perron did not believe that the words 'own priest', used by the Lateran and Tridentine councils, necessarily meant parish priest, but simply any priest delegated with care of souls through a privilege or benefice. For a curé to know his sheep, it was not essential that he be their confessor. Bishops who attempted to impose the practice of parochial confession acted beyond their jurisdictional remit and opposed conciliar as well as papal authority. ${ }^{38} \mathrm{On}$ this topic, if not on that of annual parochial communion, Pacifique was in complete agreement with the otherwise more uncompromising views of regulars like the Jesuit Jean Bagot and the Carmelite Jacques de Vernant. ${ }^{3}$

Apologists like Bagot and Vernant consistently promoted episcopal submission to papal authority, on the basis that, as it was the pope who granted bishops their jurisdiction, so too he could control or even remove it. This argument was a firm basis from which to defend regular privileges through the seventeenth century, and it formed the backbone of the regulars' arguments in every collision with their bishops. Bagot and Vernant earned notoriety for their contributions to the great upheaval in relations among bishops, curés and religious during the 1650s. Aiming to illustrate the legitimacy of regular privileges, their stance was resolutely pro-papal. Indeed, according to Vernant, those who attacked the regulars' privileges did so in order to combat the 'sovereign authority' that granted them; they were, therefore, traitorous troublemakers. ${ }^{40} \mathrm{He}$ argued that the pope was the 'visible leader and sovereign pastor of all the faithful' and cited various church councils and fathers in evidence. Not only was the pope infallible in matters of faith; ${ }^{41}$ he could, as the 'universal bishop', act in any 
area of the church without the consent of the appointed prelate, since episcopal jurisdiction was received immediately from him. ${ }^{42}$ Bishops were bound, in turn, to render him obedience. For this reason, the privileges that popes granted to religious orders were legitimate and enabled regulars to function as papal delegates. However distasteful to bishops and curés, they and their liberties had to be accommodated. ${ }^{43}$ Jean Bagot argued in a similar fashion and was, like Vernant, censured by the Paris Faculty and the 1655 Assembly of Clergy. ${ }^{44}$

If the author of Pacifique had hoped that his intervention would reconcile the episcopate and the religious orders, he was to be very disappointed. As more bishops were stung by regular opposition to their discipline, their quarrels began to assume national, and then international, significance. ${ }^{45}$ In 1625 , an alarmed Assembly of Clergy entered the fray, producing a lengthy Déclaration sur les réguliers that codified the attitudes of the French episcopate towards the religious in particular and towards episcopal jurisdiction within dioceses in general. ${ }^{46}$ It is impossible to overestimate the Déclaration's importance since it was adopted as the rule for episcopal conduct throughout the seventeenth century in France, and the overwhelming majority of French bishops propounded its explanations of episcopal jurisdiction. Officially published in 1645, it has been dismissed as a piece of paper of merely 'documentary value' until then.$^{47}$ Yet this rather superficial judgement underestimates both the symbolic and practical import of its principles. Not only did the Déclaration continue to occupy the thoughts of bishops faced with the undermining of their legitimate authority; it was persistently resorted to by the episcopate and individual bishops to vindicate their view of episcopal jurisdiction.

The immediate precipitant for this document was the complaint brought against the Jesuits by Bishop Estampes of Chartres, on behalf of Guillaume Le Prestre, the bishop of Quimper. Blatantly disregarding Le Prestre's wishes and diocesan authority, the Assembly's deputies were informed, several Jesuits had arrogantly asserted their right to administer confession and to preach on any occasion, basing their case on privileges and on an interpretation of 'own priest' that included the ordained members of their order. ${ }^{48}$ In producing its Déclaration, the Assembly clearly intended that its articles would not only resolve this particular unsavoury episode but would act as the reference point in any future clashes. Yet although the Déclaration was formulated according to the spirit of a Council that had advocated episcopal supervision of the regulars, in detail its principles proved considerably more draconian and pro-episcopal than Trent.

The bishops, for instance, claimed rights over visitation of religious communities. This was perfectly in accord with Trent, but while the Council had specified that visits were to take place annually, the Déclaration granted bishops this right at any time and subjected regulars to full episcopal supervision, 
including oversight of accounts, the election of superiors and episcopal jurisdiction over future congregations established in France. ${ }^{49}$ In order to settle disputes like that of Quimper, the articles overrode all privileges exempting regulars from episcopal control in their pastoral activities. Where Trent merely stipulated that all preachers must possess either a parochial benefice or episcopal permission, the Déclaration of the French bishops ordered that they must obtain episcopal approval to preach, regardless of whether they possessed benefices or privileges. It then decreed that regulars required episcopal permission to preach in their own churches. This precept, too, was a wholesale extension of a Tridentine directive that had merely advocated that the regulars seek episcopal benediction for this activity, and it was intended to subject regulars completely to episcopal control. It was justified, according to the bishops, by the fact that since 'the charge of preaching belongs especially to the Bishop, he is obliged to satisfy it as often as he can, at least by those he will employ for this function'. Bishops were also permitted to choose preachers in monasteries on occasions of 'processions or public and extraordinary assemblies', a step that further cemented their power of government. ${ }^{50}$ The diocesan bishop, according to the Déclaration, not only supervised the number and adequacy of regular preachers; he also held the means to dictate precisely what these proclaimed in their order's churches.

The sacrament of penance was also subjected to episcopal oversight, but again, the French regulations proved more straitened than Trent and granted complete authority to the bishop: 'The choice of persons who are employed in this ministry must particularly belong to those to whom the authority to bind and loosen was given from God, who are the bishops. ${ }^{51}$ In the area of paschal confession the articles again progressed further than Trent and presumed to interpret the Council's decrees to episcopal benefit. Having advocated the parochial mass, as Trent also did, the bishops further claimed the necessity of parochial communion and confession at Easter. The difficulty inherent in the term 'own priest' had not been clarified by the Tridentine decrees. In contrast, the French bishops presumed to resolve the question definitively and therefore to judge a controversy of canon law that had plagued the church since 1215.

The 1645 Assembly published the Déclaration officially, ${ }^{52}$ after the episcopate had waited several fruitless years for papal endorsement. Yet another quarrel precipitated publication, this time erupting in 1643 between Archbishop Henri de Sourdis of Bordeaux and his regular clergy. Once again, the clash centred on the regulars' assertion of privilege in opposition to the archbishop's interdiction upon their preaching and confessing enterprises. Predictably, the episcopate saw this as a direct attack on the independent jurisdiction of bishops within their dioceses. If it needed any further impetus towards publication, this was provided by the home-grown Jesuit Louis Cellot, who only two years before 
had produced a fiery justification of religious privileges, De hierarchia et hierarchis. Though duly censured by a highly offended episcopate, Cellot's work maintained the topicality of the episcopal-regular dispute and ensured that the bishops should continue to fear what they considered to be the persistent and anarchic lies which aimed 'to confuse the hierarchy, and the order that Our Lord Jesus Christ established in his church; to reverse the discipline of the ancient canons'. ${ }^{53}$ Twenty years of sustained quarrels between bishops and regulars and of fears for the dignity and power of the episcopal office meant that the bishops were impelled towards publication without awaiting Rome's approval.

Once the Déclaration had been officially published, the episcopate expressly referred to its regulations as the standard ground rules to be adopted in dioceses. Henri de Gondrin, archbishop of Sens, received fulsome praise from the Assembly in 1650 for his efforts to implement parochial paschal confession according to the Déclaration's rules, a policy that produced a clash between the archbishop and the regulars who refused to obey his mandates. This Assembly also wrote to all the bishops, urging them to continue to follow the official policy. Both Antoine Godeau of Grasse and Vence and Pierre Gassion, bishop of Lescar, took the time to write positive replies. Praising episcopal zeal, Godeau noted that the mark of true bishops was 'firmness to oppose enterprises which ruin the church, in ruining the power of the episcopate'. Gassion agreed, adding that he believed that the Assembly's resolutions marked a return to the discipline of the ancient church, and that they would ensure the 'respect and dependence' due to the episcopate. ${ }^{54}$

No seventeenth-century French bishop could bring himself to countenance the regulars' interpretation of church government, and their abhorrence ensnared prelates in many public 'wars of words without edification'. ${ }^{55}$ One particularly damaging episode occurred in Orléans under the tenure of Nicolas de Netz. ${ }^{56}$ In 1631, Urban VIII promulgated a jubilee and granted leave for the faithful of Orléans to confess themselves to either regular or secular priests during the paschal period. When Netz issued an ordinance contradicting this ruling and requiring parochial confession, the Carmelites, Dominicans, Jesuits, Recollects and Minims immediately appealed to the pope. Rome finally issued a response in favour of the religious orders and, with the collaboration of Richelieu, the quarrel was momentarily buried before it could attract even further controversy. ${ }^{57}$ The affair, however, clearly revealed where the regulars placed bishops in the church's chain of command. While they were willing to present their papal faculties to the diocesan bishop as a form of courtesy, they refused to accept the bishop's absolute jurisdictional hegemony over that of the pope. In the same decade, another spat caught the public eye when the archbishop of Rouen, François de Harlay de Champvallon, revoked the regulars' sacramental and preaching privileges in his diocese. Archbishop Harlay 
demanded attendance at parish mass on Sundays and feast days, and forbade religious to preach or to hold congregations and processions at this time. Regular superiors, moreover, were ordered to present their confessors to curés for their authorisation. Religious not approved in this manner would not be permitted either to confess or to communicate the sick. ${ }^{58}$

In open defiance, the regulars mounted a well-orchestrated campaign of opposition, and the Jesuits even received explicit encouragement from their general, who wrote that 'you do not have the right to abandon, to betray the privileges . . . you would be reprehensible if you did not do it. ${ }^{39}$ To resolve this dispute, a papal brief was issued in May 1634 which confided judgement to the archbishop of Sens and the bishops of Auxerre and Lisieux. Following further regular complaints to the papacy, however, this was revoked and a new brief issued the following August to transfer the affair to Rome ${ }^{60}$ But now the Assembly of Clergy threw its weight behind Harlay, arguing that this ran contrary to French liberties, which specified that the causes of France must be judged in France before evocation. To avoid the incident subsequently being treated as a precedent by Rome, the Assembly requested that the pope promulgate a bull confirming that delegated commissioners would judge future differences between bishops and regulars. ${ }^{61}$

At the time, the archbishop's disgust with the regulars' conduct and the papacy's clumsy attempts to broker peace was such that Richelieu was forced to order his silence pending settlement to prevent further upheaval. ${ }^{62}$ However, when the desired bull did not materialise, the archbishop still did not admit defeat. He oversaw the publication of several historical texts that vindicated his stance $^{63}$ by identifying how 'it is necessary to behave in the question of ordinaries and privileged'. ${ }^{64}$ Published in the early 1640s, these texts were judiciously chosen to give added legitimacy to the episcopal case through that perennially popular tool of propaganda, the appeal to historical practice. This was a tactic to which the episcopate frequently resorted in order to lend legitimacy to its claims; in the 1680s, Fénelon was still arguing that bishops' had to regain their past jurisdiction if they were to ensure that their authority and reputation were restored to their fullest expression. ${ }^{65}$ When was this high point of episcopal government? Fénelon did not identify a specific era, but François de Harlay's choice of historical texts indicated that for him it had been the middle ages, and he undoubtedly saw parallels between his situation and that of his predecessors centuries before. His Double patentes de l'ancienne église gallicane described how five French archbishops had met to deliberate in 1282, in order to resolve a dispute that had arisen over the regulars' claims to exemption from episcopal jurisdiction in sacramental administration and preaching. Each archbishop then convened a provincial council to decide on the best means of settlement and appointed episcopal delegates to implement their resolutions. ${ }^{66}$ 
When met with final and reasoned solutions, the regulars obediently submitted to their episcopal superiors (in marked contrast to their rebellious descendants). ${ }^{67}$ Harlay's resurrected texts also cited the exemplary conduct of Guillaume, archbishop of Rouen in 1285: like contemporary French bishops, he had vigorously defended his right to limit and revoke privileges abused by their possessors. ${ }^{68}$

The conduct of both Netz and Harlay provides convincing examples of practical episcopal adherence to the disciplinary definitions of the recently formulated Déclaration sur les réguliers. Neither proved willing to accept the regulars' privileges and both interpreted conciliar decrees according to their own judgement. These were essential rights if bishops were to subdue those who acted contrary to 'the hierarchical order of the church and the power and authority of bishops', and who 'not content with being subtracted from ordinary jurisdiction, under the shadow of privileges and exemptions, often imaginary and surreptitiously obtained, embark besides that on the charge of bishops and of all other ecclesiastics, either for administration of sacraments, or for all other ecclesiastical functions, which is in effect to reverse the order of the church, and to ruin episcopal dignity'. ${ }^{69}$ In practice, only the most intransigent regulars denied the necessity of episcopal approval to confess or to preach. ${ }^{70}$ Jean Bagot refused to accept it, and this was one of the principal objections to his treatise. ${ }^{71}$ But the problems generally arose firstly when bishops attempted to deny or to counteract privileges presented to them by regulars and therefore, according to regular opinion, defied the superior authority of the pope. Desperate to defend what they regarded as their traditional and legitimate rights, the regulars' controversialists understandably tended not to dwell on the dignities and honours of the episcopal office but, rather, on the pre-eminent authority of the papal office. This foundation coloured their entire attitude towards the episcopal office and its incumbents. Yet they were not alone in advocating these ideas; their view of episcopacy held much in common with their English brethren, a fact that was to become increasingly obvious to the episcopate during the 1630 s.

Even as Harlay and Netz fought their battles, English regulars were imprinting their mark on the French church through a protracted and bitter dispute over the organisation of the English mission. This conflict between the English regulars and Richard Smith, the bishop of Chalcedon, did not affect the French church in an immediate way, since it centred on the degree of Smith's authority over the religious orders working in England. The fact, however, that members of the French clergy contributed with such enthusiasm to a quarrel external to France demonstrates that its outcome was considered to have substantial repercussions for the structure and operation of the French church. Ideologically, 
Smith's cause was seen by the French episcopate and its supporters as one upon which depended future perceptions of the dignity and practical power of bishops throughout the Catholic church. In France, furthermore, unlike England, it was invariably the pro-bishop party which made the running, while the regulars, consistently pressured into disowning the anti-episcopal claims of their English brethren, were occasionally found flat-footed and always on the defensive.

Through the early 1620s, the French crown had cultivated its diplomatic links with the English Stuart regime, using the possibility of a royal marriage between the two monarchies as the means by which French interests on the continent could be protected. Both sides stood to gain from this proposed alliance: James I hoped to win French support for the restoration of the Rhineland Palatinate to his son-in-law, Frederick V, while France would obtain English assistance against the Spanish armies in the Netherlands and on the high seas. But this alliance would not be popular with English Catholics, who traditionally looked to Spain at their ally and greatest hope for the restoration of catholicism in England. Their influence could, consequently, be decisive in the success of the marriage negotiations. Accordingly, when the question of a new bishop to serve the English mission arose in 1624, it fitted perfectly into the political requirements of the French crown. Richelieu and his officials canvassed persistently for the appointment of a cleric sympathetic to France, who could be relied on to support wholeheartedly the new Anglo-French concord. Their diplomacy was entirely successful: the new bishop, Richard Smith, was a close associate of Richelieu and had been a member of his household since $1611 .{ }^{72}$

Soon after his consecration by the papal nuncio for France, the bishop of Bayonne and his powerful patron, Smith travelled to England in his capacity as bishop of Chalcedon, with responsibility for the English mission. Almost immediately, he clashed with English regulars, mainly Jesuits and Benedictines, who, none too timidly, queried his jurisdictional credentials. Was he bishop of the English clergy or merely a vicar apostolic, appointed at the pope's pleasure? Members of the religious orders had long been active on the English mission and had become accustomed to a large decree of independence in their pastoral activities. They denied that Smith was a true bishop and claimed that confessional privileges did not have to be presented to him for approval. By contrast, Smith indignantly responded that he was indeed a full bishop with jurisdiction over the pastoral activities of all Catholic clergy operating in England. The quarrel then rapidly extended to reflection on the office of bishop itself and its role and necessity within the church, considerations which were also relevant to the French church and its clergy.

Representing the position of the English regulars were the controversial publications of the Jesuits Edward Knott and John Floyd, ${ }^{73}$ each analysing episcopal power from the basis of papal authority in the church. Their attacks on 
Smith in particular and on the episcopal office shared a common root with the doctrines of French religious, even before the outbreak of the English affair. Both championed the claim that the pope granted bishops their jurisdiction. The direct consequences of this thesis were the legitimacy of regular privileges, papal power of delegation and the limitation of episcopal jurisdiction within dioceses. Knott and Floyd went even further, concluding that the pope could govern a particular church directly in times of need, temporarily replacing a bishop. As a result, they quickly became the object of episcopal animosity in France. The traditionally close links between English secular clergy, the Sorbonne and a number of French bishops also ensured that theological developments occurring in England were certain to find a receptive audience in France. Since the 1560s English Catholic exiles had regularly sought refuge in France and had been absorbed into its intellectual and ecclesiastical life. ${ }^{74}$ The career of Richard Smith is an illuminating example of the network of personal and professional ties binding English and French clergy: during his fourteen years in France Smith had been a member of Richelieu's household, but was also a founding member of the Collège d'Arras, a Parisian house of study for English priests, from which a stream of Catholic controversial literature had flowed since it opened its doors in $1611 . .^{75}$

It was, therefore, entirely natural that French churchmen should take an interest in the events in England. French regular writers did not touch on a number of the issues that Knott and Floyd discussed because they were not immediately relevant in France. Even so, their ideological and theological importance was considerable, and many regarded them as a menace to the episcopal office in France and throughout the Catholic church. With enthusiastic episcopal applause, lengthy refutations were published in France, proposing an image of episcopacy and of the role of bishops within the church which was quite at variance with that of the English and French regulars, and which strongly rebutted the claims of both. Conceptions of episcopacy were already evolving independently in France during this period, but the Smith affair undoubtedly propelled developments forward more rapidly.

In this inflamed atmosphere, the bishops operated a strategy of guilt by association. They began with vigorous but vaguely worded condemnations of Knott's and Floyd's 'dangerous, seditious, impious, schismaticall, blasphemous' attacks on hierarchical order and the episcopate. ${ }^{76}$ A delegation of eight bishops then extracted erroneous propositions from the Jesuit apologies, which were duly censured by the Sorbonne in 1631. The archbishop of Paris even produced his own censure, ${ }^{77}$ while thirty-four bishops signed a letter addressed to their fellows stressing the danger to hierarchy posed by the English attacks and colourfully claiming 'to feel the wounds of that unfortunate Church, as if they had beene given to our selves'. Since it was normally only 
for what were perceived as the most urgent and potentially damaging situations that extraordinary meetings of the bishops took place, it is obvious that the episcopate was particularly alarmed by the cross-Channel bombardment, so offended, in fact, that as 'watchmen' of the church they felt obliged to condemn the errors 'against the holy order of Bishops' which 'disturbe the Hierarchie of the Church' ${ }^{78} 8$ Addressing their fear that French Jesuits would rally to defend their English brethren, the bishops forced them to disavow their works publicly. ${ }^{79}$ Seeking further reassurance, they then compelled the superiors of all the major religious orders to sign a declaration admitting the need for episcopal approval for preaching and confessing. ${ }^{80}$

The bishops made their master move, however, when they endorsed the propaganda produced in their defence. Three major treatises brought positive publicity to their cause, and presented articulate and thorough justifications of episcopal authority. The most celebrated champion of episcopacy to emerge from the affair was the Abbé de Saint-Cyran, Jean Duvergier de Hauranne, who, writing under the pseudonym Petrus Aurelius, entered the fray in 1632. Saint-Cyran is a familiar figure to scholars today: during his tumultuous life he associated with leading ecclesiastical reformers like Bérulle and Angelique Arnauld; he was a devoted friend of Cornelius Jansen, the author of the infamous Augustinus; most notoriously, he earned the ire of Richelieu, who sent him to stew in the Vincennes for several years after they clashed over theology and politics. ${ }^{81}$ But during the 1630s, Saint-Cyran also caught the public eye for his spirited defence of episcopacy, though his principal works, Vindiciae censurae and Assertio, were not the only productions to appear in opposition to the condemned Jesuit publications. ${ }^{82}$ François Hallier and Nicolas Le Maistre both contributed important treatises to the debate, Hallier the Defensio ecclesiasticae hierarchiae and Le Maistre the Instauratio antiqui episcoporum principatus. ${ }^{83}$ In fact, it was Bishop Augustin Potier of Beauvais who, with the support of his fellow bishops, actually requested Hallier to write his Defensio. ${ }^{84}$ They were less candid in their enthusiasm for Saint-Cyran's contribution, but only because they decided to use its reputation and skilful rhetoric as a means to defend themselves. Their unofficial assembly actually censured Saint-Cyran's works in return for the Jesuit disavowal of Knott and Floyd. But that censure was couched in terms which praised Saint-Cyran's zeal and 'the care that he had to defend an orthodox doctrine and the ecclesiastical hierarchy'. His only error had been, it admitted, to include some 'invectives' in his works. ${ }^{85}$ With judicious language, the bishops neatly turned what was ostensibly a censure into a positive affirmation of their champion's ideas.

These powerful polemics rested their case on the assertion that particular churches should always be provided with a bishop whose inherent episcopal powers could not be restricted by the pope. Beginning from this premise, the 
path of their thought was bound to be radically different from that of both French and English regulars because they laid the emphasis on episcopal rather than papal authority. Each of the French writers drew here on the work of Matthew Kellison, penned in support of Smith's position and answered by both Knott and Floyd ${ }^{86}$ In the Assertio, Saint-Cyran admitted that the pope could reform judgements of faith made by bishops in their dioceses, but pointed out that judgements made by bishops actually highlighted papal splendour. ${ }^{87}$ Though Saint-Cyran was not anti-papalist, he was staunchly pro-episcopal. In fact, he never attacked the pope directly in his written works, but Vincent de Paul recorded that 'he had never seen anyone who esteemed the episcopate more than' Saint-Cyran. ${ }^{88}$

For these apologists, the purpose of particular churches was to provide instruction, sacramental administration and discipline for the clergy and laity. Since these were the primary duties of bishops, these officers were absolutely essential in the universal church and in local churches. If local or particular churches did not possess their own bishop then they would simply cease to exist. Under no circumstances could the pope replace bishops by attempting to rule particular churches directly. ${ }^{89}$ This principle held even in time of persecution, according to Hallier, since a bishop then offered the faithful his consolation as well as his jurisdiction, for 'the convenience and good of the church'.$^{90}$

In affirming episcopal indispensability, its defenders also declared that bishops held their jurisdiction by droit divin, meaning that it was passed to them immediately from Jesus Christ and not from the pope, as both French and English regulars insisted: 'Episcopal power in the church is from divine law; or it is from divine law, that some bishops may exist under the sovereign pontiff, [they] may govern particular churches. ${ }^{, 91}$ Within this point lay the potent implication that the pope could not interfere with or limit the diocesan jurisdiction of bishops since it was not he but God himself who granted it to them. This thesis and another, that the pope could not rule a particular church directly, effectively scuppered the regulars' argument on privileges, for they had founded their defence of their pastoral activity on precisely these bases. Thus, Le Maistre contended that regular privileges were contrary to church law and should not be permitted. He ended with the caustic observation that religious should submit to the common law of the church, just as other clergy were obliged to do. ${ }^{92}$

While stressing the jurisdictional power of bishops in their writings, Saint-Cyran, Hallier and Le Maistre did not neglect the episcopal power of order. Actually, they had little choice, for the English Jesuits had already dissected it under the categories of confirmation and religious perfection, and a spirited riposte to their conclusions was essential. When they denied the necessity of bishops for the existence of particular churches, the Jesuits also 
argued that confirmation was not vital for the perfection of Christians. If this was so, then local churches did not need bishops to administer this sacrament. In any case, because the anointment by the bishop did not form the essential matter of confirmation, a delegated priest could administer it. According to John Floyd: 'All Divines say Confirmation is not commaunded, but onely cum commode haberi potest, when it may with commodity be had, or as others say, commodissime, when it may be had without any the least incommoditie. ${ }^{93}$ In response, Hallier insisted that confirmation, carried out by bishops, was indispensable for Christian perfection. ${ }^{94}$ Furthermore, to claim that ordination was the only reason for which a bishop might usefully be appointed to a persecuted church was, wrote Saint-Cyran with devastating reproach, simply a renewal of the Calvinist heresy; the regulars' next step, in other words, would be to abandon the age-old office of episcopacy for the poisoned chalice of presbyterian ecclesiastical government. ${ }^{95}$ It is significant that both the French and English regulars differentiated bishops and priests primarily on the basis of the bishops' power to ordain, rather than on their power of jurisdiction. French authors differed from English, however, in the fact that they did not discuss the sacrament of confirmation in this context, since in the disputes between French regulars and bishops, the actual necessity of bishops within the church was never denied. It was the character of their office and the extent of their authority that preoccupied them and led the regulars to emphasise power of ordination rather than of jurisdiction.

Saint-Cyran and his fellow polemicists also felt obliged to refute a further provocative claim relating to episcopal and regular perfection. French regular authors alleged that ordained members of religious orders formed part of the governing hierarchy of the church. Knott and Floyd forwarded a more extreme view, initially by their failure to differentiate between ordained and nonordained religious. But even more seriously: 'Religion is a state of perfection to be gotten, whereas the state of Bishops is a state of perfection allreadie gotten. To be in the state of perfection allreadie gotten, doth not import to be in a state, by profession wherof perfection is actually gotten, but to be in a state which supposeth a man to be aforehand perfect, givinge him no means proper to his state, to be made perfect. ${ }^{96}$ The episcopal office was perfect in its nature, therefore, but its incumbents were not necessarily personally flawless. The state itself did not inherently contain the means to draw bishops to perfection. In contrast, the religious state did, by virtue of its vows of poverty, chastity and obedience. As a result, it was more excellent than the episcopal. Indeed, it was more probable that religious, in fulfilling their vows, would attain perfection than that bishops would reach the perfection intrinsic to their office.

The French episcopal apologists rejected Knott's and Floyd's claim out of hand. In doing so, they stressed the nobility of bishops and the 'eminent status 
of episcopal perfection above the status of religious perfection'. In fact, they argued, religious were reliant on bishops, as were all sections of the faithful, to achieve perfection. ${ }^{97}$ A prelate's primary function was to perfect through the direction of souls, employing his divinely granted powers of order and jurisdiction; contrary to the claims of Knott and Floyd, that function was not inherent to the religious state. ${ }^{98}$ This stress on the majesty, authority and perfection of the episcopal office was identical to the views of major clerical reformers like Bérulle and Condren. Saint-Cyran also emphasised the perfection of the episcopal office and the essential obedience of priests to prelates, and drew both notions to the conclusion that privileges could not exempt regulars from episcopal rule and, in effect, overturn the hierarchical order. It followed that prelates held their jurisdiction by droit divin and that they delegated hierarchical functions to regulars when necessary. He adopted Bérullian concepts of ecclesiastical hierarchy to counteract regular threats to episcopal authority, pushing what was implicit in the cardinal's endorsement of episcopal diocesan authority to its logical conclusion.

On the other hand, the advocates of episcopacy involved in the Smith affair did not lay great emphasis on the personal sanctity of bishops because the pressing context in which they wrote forced them to concentrate on the dignity of the office and its powers of order and jurisdiction. But the question of the personal perfection of bishops was not a dead letter in this controversy, since both Knott and Floyd had disparaged the ability of bishops to achieve personal holiness. Smith's French apologists could not, therefore, ignore the issue entirely. In particular, Saint-Cyran and Hallier recorded reflections on episcopal sanctity which were close to those propagated by Bérulle, Eudes, Olier and their disciples.

Saint-Cyran's Vindiciae tendered an extended exposition of Bérullian sacerdotal theory. ${ }^{99}$ He based his understanding of the priestly vocation on the elevated dignity deriving from participation in the eternal priesthood of Jesus Christ; the ordained represented Jesus Christ 'preaching . . . remitting sins, and continuing all that he did' ${ }^{100}$ His writing testifies to the rapid dissemination of the reformers' views within the French church, as well as to their importance in drawing attention to the hierarchical status of bishops. The priest had to abandon his soul and spirit to his prelate 'by the obedience that he vows to the bishop for his whole life . . . this obedience [is] rendered to the resuscitated Jesus Christ that the bishop represents when he consecrates a priest; I must have the same submission to the command of the bishop, as to the command of Jesus Christ'. ${ }^{101}$

Saint-Cyran's understanding of the episcopal power of order, however, did not advance as far as that of Jean-Jacques Olier, which identified a specifically episcopal spirit enabling the bishop to vivify his clergy. ${ }^{102}$ But his thought 
did imply the existence of a unique episcopal grace that permitted bishops to perfect those below them in hierarchical rank. Furthermore, the exalted status of episcopacy meant that bishops should be of sound vocation and irreproachable in sanctity and charity. ${ }^{103}$ Comparing bishops to the prophet David, SaintCyran noted that God had distinguished them from all others as the best among his people. 'The excellence of the bishop' lay in his 'virtue above all his diocese', as appropriate to a pastor of souls. ${ }^{104} \mathrm{He}$ achieved his personal merit, according to François Hallier, through a conscientious fulfilment of the hierarchical functions of ordination and preaching, as well as through frequent prayer, study of Scripture and sacramental administration, particularly of the eucharist. Contrary to the claims of Knott and Floyd, the episcopal state did, consequently, contain within itself the means by which its incumbents could attain personal virtue and sanctity. ${ }^{105}$

When the regulars and bishops clashed over pastoral activities, the parish clergy invariably took notice. Throughout the seventeenth century, there was a great deal of antagonism between religious and parish clergy, frequently boiling over into open rows that entangled bishops, regulars, curés and the papacy in claims, counter-claims, threats, strong-arm tactics and public stand-offs. When curés became embroiled in disputes with members of the religious orders, they soon produced well-defined views on authority and priesthood which acutely restricted episcopal power. The curés' conflict with the regulars was not the sole factor to influence their antipathy towards bishops, however. Their distaste for episcopal 'tyranny' also brought them to a definition of episcopacy which was profoundly unattractive to their bishops.

The key theme in the development of the curés' self-consciousness was droit divin, meaning that they held their jurisdiction directly from Christ and not from their bishop. Richard Golden has identified this as a fundamental and unprecedented factor among curés in what he terms the Parisian religious Fronde of the $1650 \mathrm{~s},{ }^{106}$ but it was in fact proposed by curés many years before. Even during the 1650s, the Parisian parish clergy were not alone in adopting and publicising the doctrine. They were temporarily, however, its most powerful guardians, for a time successfully assembling as a corps despite intense opposition from the royal government.

Even while he locked horns with Rouen's regulars, François de Harlay found himself at odds with a vocal group of parish clergy. The conflict was not at all related to the regulars, for the curés' grievances hinged on diocesan government and were elaborated at length by Pierre Morestel, doctor of theology, curé of Saint Nicolas de la Taille and one of the chief agitators for the parish clergy. Along with two other curés, he appealed to the parlement of Rouen in 1631 against disciplinary measures taken by Harlay. After the parlement upheld 
their plea, Morestel published a vindication of the curés' position entitled Le Guidon des prélats et bouclier des pasteurs, in which he placed the blame for the conflict squarely at the feet of the archbishop.${ }^{107} \mathrm{~A}$ furious Harlay then appealed to the Conseil d'État in order to have the parliamentary decision revoked. As well as obliging in this, the Conseil upheld Harlay's censure of Guidon, noting that its examiners had found in it several pernicious falsities that wounded episcopal authority and the ecclesiastical hierarchy. Immediately, a jubilant Harlay made the most of his victory by publishing the conciliar decree. ${ }^{108}$

Guidon contained a great deal that displeased the prelate. Morestel began his attack by complaining about the excessive monetary exactions demanded by the archdeacon Behotte on his visitations, ${ }^{109}$ and then slammed the simonical abuses of other officials. ${ }^{110}$ But these were just symptomatic of a more fundamental problem: Harlay's high-handed attitude failed to accord to the curés their legitimate role in ecclesiastical government or even to take any cognisance of their wishes. This was the greatest and most unbearable injustice, for they no longer had any influence in the policies of their autocratic bishop. Illustrative of the bishop's arrogance was the form of language in his mandements, which portrayed curés as passive servants to be disciplined and coerced rather than as his brothers. The only viable solution was to restore the curés' traditional right to a deliberative and decisive voice in synods, so that they were ascribed the 'honour and rank which [was] their due'. ${ }^{111}$

The claims by Morestel on behalf of Rouen's curés were based on their perception of 'curial' (a term adopted by Golden) status within the hierarchy. According to this argument, curés were captains operating under bishops within the church, flamboyantly depicted by Morestel as a ship of war combating for the faith of Jesus Christ. ${ }^{112}$ Curés were 'episcopal helpers'; as a result, their legitimate deliberative voice should be heard so that unity of spirit would once again reign between them and their bishop. Morestel also traced the historical legitimacy of the curés' office, asserting, like Gerson, that they were the successors of the seventy-two disciples chosen by Jesus Christ. Significantly, he then proceeded to the far more audacious claim that, as such, they held their jurisdiction immediately from God or, in other words, by droit divin. ${ }^{113}$ As a result, the curés' state was 'next to the state of bishops in order', for the only difference between them was the bishop's power of order. ${ }^{114}$ Morestel thereby implied that bishops could not interfere in the jurisdiction of curés, guardians of parishes. ${ }^{115}$ This was a supreme manipulation of jurisdictional droit divin, deftly turning the tables upon the episcopate to attack its power.

Edmund Richer had already suffered censure for his provocative claim that curés should share in diocesan government. ${ }^{116}$ Still, that crisis had happened almost over twenty years before and no curé had dared to endorse his opinion then or since. In fact, Morestel and his allies proved the first within their group 
to embrace a version of Richer's views overtly and to organise a concerted campaign of resistance to their bishop on that basis. During the 1650s their claim to droit divin was harnessed by other curés in Paris and Angers, though the context of each episode differed. However, they shared a common antagonism towards the regular clergy that spilled into a radical rejection of episcopal authority over curés. The first sign of trouble in Paris was the publication of Nicolas Mazure's L'Obligation des fidèles in 1653, ${ }^{117}$ a work which freely admitted that curés held their jurisdiction by droit divin. Shortly afterwards, the Parisian curés swooped to the defence of their archbishop, Retz, when the crown proposed to try him for his alleged involvement in the Fronde. In 1653, they began to meet in corporate assembly to combat the crown, the regulars and, ultimately, the episcopate through communal actions and declarations. While others abandoned Retz to his fate, they proved his most resolute sympathisers through the 1650s. Simultaneously, they and the curés of Rouen, supported by their brethren in a number of other dioceses, conducted a vigorous campaign against Jesuit casuistry, culminating in their attempts to ensure the censure of Pirot's L'Apologie pour les casuistes, a work of casuistic probabilism that they labelled morally lax and theologically unsound. ${ }^{118}$ They thereby assumed the right to judge an issue of doctrine, an extraordinary 'usurpation of the authority of the bishops' who believed that they alone possessed that right. ${ }^{119}$

The quarrel in Angers was driven, more straightforwardly, by antagonism between the curés and the regulars who seemed to threaten their primacy in pastoral care. The curés' case was passionately defended in the three publications of François Bonichon, curé of Saint Michel du Tertre, printed between 1656 and 1658 at the height of tension. ${ }^{120}$ After the mendicants challenged the exclusive right of the parish clergy to administer confession to parishioners during Easter and on their deathbeds, Bishop Arnauld issued a series of ordinances to curtail their sacramental privileges. ${ }^{121}$ When the mendicants fiercely rejected these prohibitions, Bonichon produced his treatises vindicating Arnauld's protection of his curés, but still managed to slip into them a pithy justification of the curés' jurisdictional droit divin. First, he declared that regulars were subject to bishops when they performed their pastoral functions; bishops had, consequently, to approve their privileges before they could legitimately be used. He twice stated emphatically that bishops could do this because their jurisdiction was not subservient to the pope's; they held this power de droit divin. ${ }^{122}$ Then he progressed to Trent's legislation, meticulously responding to every conceivable eventuality. Pre-Tridentine popes, he began, had never issued bulls granting apostolic delegation to regulars for hierarchical functions. ${ }^{123}$ Even if they had, the Council of Trent had cancelled their validity. In the Council's wake, no pope had confirmed privileges which ran contrary to its decrees. ${ }^{124}$ So, Bonichon concluded, Bishop Arnauld had acted quite properly when he forbade regulars to 
hear confessions and preach without his leave, because Trent, earlier councils, French provincial councils and assemblies as well as individual church doctors and bishops had endorsed this kind of prohibition. ${ }^{125}$ Annual parochial confession and mass were anyway essential, as the bishop had ordained, as was parochial sacramental administration in general. Bonichon evidently understood the 'own priest' stipulation, voiced by the Fourth Lateran Council and confirmed by Trent, to be a reference to parish priests therefore, and not simply to any priest with charge of souls, as the regulars claimed.

Yet for Bonichon it was even insufficient for regulars to get episcopal approval in administering confession. The consent of parish curés should also be sought and gained before any religious dared to confess the faithful, particularly in the case of paschal confession. Bonichon did soften this stern directive by adding that curés should grant leave to regulars to confess in their parishes when necessary but, on the other hand, this simply portrayed his conviction that curés were masters of their territory. ${ }^{126}$ The same sentiment had earlier been expressed by a curé in Rouen, further demonstrating that parochial observance remained a divisive and unresolved issue throughout the decades. In 1620, Michel François David, defending himself from the criticisms of regulars, affirmed the need for annual parochial confession and communion, unless the local curé permitted otherwise. He maintained, as Bonichon did, that this was the doctrine of Lateran IV and Trent, as well as being the policy followed by his archbishop. ${ }^{127}$ Its practice resulted in considerable conflict between Archbishop Harlay and his regulars just fourteen years later.

Underpinning all of these claims were potent common principles. The curés of Angers and Paris believed that they were the direct successors of the seventy-two disciples and that they held the jurisdiction inherent to their office de droit divin. The first was not a radical assertion for, among others, Jerome, Bede and Aquinas had all taught it. ${ }^{128}$ The curés' second claim was far more extraordinary, though here they were following in Gerson's footsteps. ${ }^{129}$ The Parisians' attempt to establish themselves as a corporate body represented by assemblies was built upon the premise that curés formed a separate rank or grade within the ecclesiastical hierarchy, with specific rights of jurisdiction. While the bishop ordained priests and conferred subjects, Christ granted the all-important governmental powers that allowed parish priests to influence the government of their diocese. Morestel had also claimed this and Bonichon's argument implied it, but it was the Parisian curés who put the idea into effective practice, to the utter dismay of the court and the episcopate.

It is, of course, significant that Bonichon's confreres in Angers were among those who supported the actions of the Parisian parish clergy in the late 1650s. In 1659, they wrote to the Parisians, requesting information on the procedures of the assemblies because they were interested in forming one 
themselves and acting, therefore, corporately. ${ }^{130}$ Their request simply reflects their attitude through the 1650s. It was further proof that, however displeasing to the episcopate, Richer's was not an isolated voice in the seventeenth century. His views proved highly attractive to curés who sought to clip the wings of both bishops and regulars, through bolstering their autonomy in parochial affairs but, simultaneously, demanding a more instrumental role in diocesan government. This was an ambition which sought the best of all worlds for the parish clergy, and it was almost bound to prove unfavourable to those who lost out at its expense. For the curés' version of droit divin carried dramatic implications for the episcopal office and coloured the entire relationship between parish priests and diocesan bishops. Their assertion seriously circumscribed the authority of bishops within their dioceses, since, should a curé object, his bishops could not intervene in the government of his parish. It was a radical doctrine, and in its own way just as subversive of episcopal authority as the pro-papal argument of the religious.

The curés admitted that, as eminent members of the ecclesiastical hierarchy, bishops were the guardians of 'knowledge and eternal truth', ${ }^{131}$ and 'the head[s] and heart[s]' of their dioceses, ${ }^{132}$ around whom all else functioned. But Morestel added a cautionary note: the dignity of episcopal office demanded habitual study and prayer, as well as a life of supreme virtue, 'for the people turn themselves promptly and conform easily with the nature of their prelate. ${ }^{{ }^{133}}$ Continual self-edification in the virtues of piety, probity and prudence would ensure that the bishop maintained peaceful relations with his clergy and laity as well as providing an enlightening example for Christian living.

However, the curés' position was complicated by the fact that they accepted the validity of their and the episcopate's jurisdictional droit divin. ${ }^{134}$ Their principal, and particularly sticky, dilemma then became to reconcile both claims. How could these two groups, each equally sensitive, exist comfortably within the church's hierarchy without one persistently infringing on the rights of the other? There was no simple answer to this but the curés could find a convenient point of departure in presenting the bishop as the protector of parish priests. Thus they wholeheartedly embraced the bishop's authority over the hierarchical functions of regulars since it potentially benefited them. But the relationship between bishops and parish priests was less straightforward; instead of a vertical bond of authority, there existed one of co-operation in which the principal distinction between the two offices was the episcopal power of order. French regular authors also understood the difference between bishops and priests as chiefly one of order, but this was for entirely different motives: they wished to emphasise papal jurisdictional authority in order to support their claims of privilege. The curés, on the other hand, based the differentiation primarily on the episcopal power to ordain and confirm because 
they wished to assert the autonomy of their parochial government and to take advantage of the related idea that the jurisdiction of the diocesan bishop was not considerably greater than theirs. As the bishop's jurisdiction was held independently of the papal will, so too that of the curé was independent of the bishop's will. In stressing power of order as the main distinction between bishops and priests, although for different and self-interested reasons, both regulars and curés limited episcopal jurisdictional authority for their own benefit.

Within limits, therefore, the curés supported the jurisdictional powers of bishops, particularly towards the papacy and religious orders. Bishops were hierarchical fathers and superintendents, ${ }^{135}$ but if, as Morestel stressed, their directions proved 'useless to the church, or are directly or indirectly repugnant to the law of God and of his church, [we] are not obliged to obey the prelates'. ${ }^{136}$ So Bonichon found it quite easy to agree with Henri Arnauld's ordinances, since they contained nothing detrimental to the jurisdiction of the Angers curés and, in fact, safeguarded their position. The bishop was to use his authority to protect the activities of the parish clergy and to uphold their inviolable jurisdiction. ${ }^{137}$ In this manner, episcopal and curé jurisdictions were reconciled. Bonichon's support of Arnauld's actions and authority also explains why his publications, unlike those of the Rouen and Parisian curés, did not suffer official censure. ${ }^{138}$ Indeed, the bishop of Angers welcomed them, even though they embraced the doctrine of droit divin for curial government. In Bonichon's case, the advantages of his argument were perceived to outweigh the disadvantages. A similar sentiment guided Arnauld and other bishops when they co-operated with their curés' written demands for the condemnation of Pirot's Apologie. ${ }^{139}$ Judiciously, they tolerated their clergy's initiatives since they too wished to quash the form of probabilism contained within the Apologie, and a united onslaught was the most efficient method of ensuring this. But by agreeing with their curés' wishes, the bishops also cannily removed the threat of their acting independently of them, as a distinct corps within the ecclesiastical hierarchy.

In many of his publications, Jean-Pierre Camus, bishop of Belley, consistently defended the curés' pastoral rights, noting that regulars should aid them by working 'with them, for them and by them, with subordination' according to the hierarchical structure of the church. ${ }^{140}$ Moreover, while affirming the authority of bishops to approve privileges, he urged that they consider their curés' wishes by accepting only those regulars to whom the parish priest held no objection. ${ }^{141}$ This kind of support from bishops perhaps contributed to mollify some of the curés' grievances about episcopal autocracy. At the same time, however, it combined with the contemporary elevation of the priestly vocation by Bérulle and his disciples to produce curés who by the 1650 s were confident enough in their conceptions of their legitimate status to present an articulate challenge to the episcopate as well as to the regulars. The episcopate could not 
afford to ignore their militancy, and it was certainly not often in its best interests to do so. The curés' claims threatened the very foundations of episcopal power within dioceses, a danger that was never more obvious than during the 1650s. Perhaps the bishops proved particularly sensitive to them in this decade because they coincided with yet another rebellious thrust by the regulars; they were now impelled to fight wars simultaneously against two vocal quarters of the lower clergy. In 1653, Nicolas Mazure published his justification of curial jurisdictional autonomy; it was followed two years later by Jean Bagot's refutation of its anti-regular doctrines. Soon afterwards, the Parisian curés began to issue declarations as a united corps. Simultaneously, the jostle between the bishop of Angers and his regulars came to public notice through Bonichon's treatises. As each successive wave of provocation was launched, the Assembly's episcopal deputies began to plan a bold riposte that would demolish their enemies once and for all.

The Assembly's first step was to censure the displeasing treatises by Mazure and Bagot, for their 'dangerous doctrines' threatened 'the discipline established by ecclesiastical law' and 'the jurisdiction [of] bishops . . . over priests and curés'. ${ }^{142}$ Yet a simple censure, and a reiteration of the episcopate's authority over the sacramental functions of priests, did not nearly answer the bishops' anxiety. To set their minds at rest, the deputies produced a set of twelve articles in 1657, which defined the jurisdictional relationship among bishops, curés and regulars in uncompromising terms. ${ }^{143}$ These clearly expressed the episcopate's continued support for the curés' administration by confirming that the faithful could 'confess themselves in assurance and usefully to regulars privileged by the pope', only 'when the bishops by their approbation have rendered them suitable and licensed for this function in their diocese, as the Council of Trent says'. The articles also decreed that bishops were permitted to limit and revoke privileges. Finally, the episcopate again extended Trent's decrees and assumed the right to interpret and augment its regulations, by stipulating that the faithful must confess annually to their parish priest. ${ }^{144}$

Although, however, the articles gave precedence to curés in the pastoral care of parishioners, they offered no concessions to those curial claims which injured episcopal jurisdiction. On the contrary, the articles expressly affirmed the bishops' jurisdiction over curés as well as regulars: bishops could administer sacraments and preach within parishes or delegate others to do so since curés held their jurisdiction not de droit divin, but directly or immediately from their bishop. These rulings necessarily laid particular emphasis on the difference of jurisdiction between bishops and priests, a point that the curés attempted to reduce in significance. They were an emphatic statement of episcopal hegemony, which insisted that the power of bishops extended into every diocesan parish and over every parish priest. But it is obvious from the positions taken 
up during this quarrel that, like the regulars, neither French bishops nor curés claimed the episcopate to be a sacramental order, distinct from the priesthood. Moreover, it is apparent that bishops, curés and regulars were also in agreement on the question of the episcopate's power to perfect. Here all followed Trent's teaching, although only the episcopate adopted it entirely, just as the major French clerical reformers did, by stressing the powers of order and jurisdiction. In fact, Olier's 'Projet', elaborating this view, had been presented to the Assembly just six years before the episcopate's dogmatic declaration on its jurisdictional authority. ${ }^{145}$

The bishops continued to cling to their principles in the wake of the crisis of 1657. In fact, when the Assembly met in 1665, it was presented with the perfect opportunity to do just that. Knowing that a diocesan structure had been devised for the developing Canadian church, and that François de MontmorencyLaval had recently been appointed vicar apostolic of New France, it confirmed that the 1657 articles were applicable in the colony. ${ }^{146}$ However, a striking innovation now entered the frame to strengthen the bishops' hand further still: the possibility of comprehensive royal legislation to endorse the position that they had elaborated in their own legislation. The first inkling that the bishops could expect this support appeared in 1669 in response to a quarrel over preaching and confession between Bishop Joly of Agen and several religious orders. ${ }^{177}$ When the regulars appealed successively to the local parlement and Rome against Joly's ordinances, he used his ties at court to leapfrog over both to the Conseil du Roi, where he might hope for a judgement in his favour. To close the matter, Louis's gallican ministers were only too happy to issue an arrêt confirming that Agen's regulars could not preach or administer penance without episcopal leave, which could be revoked at any time. ${ }^{148}$ That intervention set a precedent for the future, for the episcopate could now point to it when requesting that the crown uphold its conception of governmental discipline.

This potentially beneficial novelty was again in evidence some years later, but it resulted, this time, in a victory for every bishop in France. When the Assembly of Clergy met in 1695, the crown's most pressing ambition was to wrangle a substantial don gratuit from the clergy so that Louis XIV could continue to finance his nine-year war against the anti-Bourbon European powers. ${ }^{149}$ Of course, it required a well-disposed set of deputies to achieve this, and an edict placing regulars and curés under episcopal authority in French law was potentially the perfect bargaining tool. In return for a subsidy of ten million livres, the episcopate achieved a dearly held wish: royal support for its jurisdiction over the lower clergy. As well as confirming the right of bishops to visit all monasteries and convents, the edict decreed that all clergy, except curés, required episcopal approval before administering the sacrament of penance. It further specified that the regulars could not preach without 
episcopal benediction. Additionally, it was the bishop's prerogative to refuse or revoke his approval of these activities or even to limit 'the places, the persons, the time and the cases'. ${ }^{150}$

Although this edict, registered with alacrity by the Assembly, simply rubber-stamped the ecclesiastical legislation produced over the course of the century, it was, as a royal declaration, with writ throughout the realm, a powerful weapon at the bishops' future disposal. Just as significant for the episcopate's confidence and stature was the fact that it functioned as a complete vindication of its view of hierarchy and government within the church. Perhaps it was not quite as significant a landmark as the articles of 1657, for it was built on the principles that those articles had first expressed. Yet, even so, it was the crowning achievement of the episcopate's century-long campaign to ensure that its opinion prevailed over the French church, despite the best efforts of its opponents. It was not surprising that the bishops should prove so dogged in their determination to quash the threats to their authority from the lower clergy. For while the honour of the episcopate proved a popular refrain among regulars and curés, each camp concentrated overwhelmingly on protecting its own position and achieving its own aspirations. Each had a particular agenda to promote, and both tended to conflict with that of the episcopate. In fact, in the series of jostles between the bishops and lower clergy it was only the pro-Smith authors who really favoured bishops and genuinely fought to assert their rights for no other motive than to defend their office and powers. In this affair particularly, the episcopate displayed a keen sense of the issues at stake, and was canny enough to harness all possible weapons to promote and defend its jurisdictional convictions. Ultimately, that determination was to bring the bishops even greater success as the century progressed, for while neither the regulars nor the curés of France might have liked it, they were forced to swallow the fact that the episcopate's vision had become the official policy of the French church.

Notes

1 See, for example, Bonnot, Arnauld, pp. 251-70; Golden, Rebellion; Peyrous, Réforme.

2 Procès-verbaux, iv, pp. 70-1: 'Nous n'en pouvons souffrir la diminution sans être plus coupables que ceux qui font la faute.'

3 Yves Congar, 'Aspects ecclésiologiques de la querelle entre mendiants et séculiers dans la seconde moitié du xiii ${ }^{e}$ siècle et le début du xiv ${ }^{e}$ siècle', Archives d'Histoire Doctrinale et Littéraire du Moyen Âge, 28 (1961), 35-151.

4 The Minims had approximately two thousand members during the seventeenth century: Taveneaux, Catholicisme, i, pp. 57-95; P. Whitmore, The Order of Minims in SeventeenthCentury France (The Hague 1967), p. 21.

5 See ch. 2, p. 55.

6 Richer then fought a long battle with ultramontanes over his denial that the church could intervene in the temporal realm and over his endorsement of ecclesiastical conciliarism: Martin, Gallicanisme politique, p. 125; Martin, Réforme, pp. 360-4; Edmond Puyol, Edmond Richer. Etude historique et critique sur la rénovation du gallicanisme au commencement du xviie siècle, 2 vols (Paris 1876), i, pp. 160ff. 
7 John McManners, French Ecclesiastical Society under the Ancien Régime. A Study of Angers in the Eighteenth Century (Manchester 1960), pp. 173-81; Edmon Préclin, Les Jansénistes du xviiie siècle et la constitution civile du clergé. Le développement du richérisme. Sa propagation dans le basclergé: 1713-1791 (Paris 1929); Timothy Tackett, Priest and Parish in Eighteenth-Century France. A Social and Political Study of the Curés in a Diocese of Dauphiné (Princeton, New Jersey 1977), pp. 225-86.

8 Leonard Chastenet, La Vie de Monseigneur Alain de Solminihac évesque baron, et comte de Caors, et abbé régulier de Chancellade (Cahors 1665), p. 358. Earlier editions of this work appeared in 1662 and 1663. De Paul, Correspondance, iv, p. 189, Solminihac to de Paul, 26 April 1651.

9 Henri IV, François de Sourdis et l'affaire des autels. Trois lettres inédites du roi Henri IV, ed. E. Allain and P. Tamizey de Larroque (Bordeaux 1893), pp. 8-11; Ravenez, Sourdis, pp. 50-9.

10 Allain and Tamizey de Larroque, Sourdis, pp. 11-16.

11 Sauzet, Contre-réforme, pp. 113-15, 341-4.

12 Antoine Degert, Histoire des évêques de Dax (Paris 1903), p. 328; de Paul, Correspondance, iii, p. 241, letter to Jacques Desclaux, 2 October 1647.

13 Canons, ed. Schroeder, Sess. XXV, ch. 5 I-XXII, pp. 217-32.

14 Ibid., Sess. XXIII, ch. XV, p. 173, and Sess. XXIV, ch. I, p. 195.

15 Ibid., Sess. XXII, p. 152.

16 Several studies of local reform have examined clashes between reforming bishops and the convents in their dioceses. These usually occurred when the bishop attempted to visit and discipline the convent, which, in resisting, claimed to be customarily independent of his jurisdiction. For a particular instance of this, see Jean Valette, 'Nicolas Sevin, evêque de Sarlat (2 mai 1648 - septembre 1657)', Actes du 96 Congrès National des Sociétés Savantes, ii (Paris 1976), pp. 62-4. This dispute pitted Sevin against the Recollects, the Cordeliers and the religious of the Convent of Sainte Claire.

17 Giuseppe Alberigo, Lo sviluppo della dottrina sui poteri nella chiesa universale (Rome and Freiburg 1964), pp. 36-84.

18 John Bossy describes Lainez's position as 'missionary' in his postscript to Evennett's Spirit. Though basically correct, the term is a little misleading, for its narrow meaning in this context suggests that those who opposed Lainez had no sense of mission: Evennett, Spirit, pp. 99-102, 135-8.

19 Canons, ed. Schroeder, Sess. XXV, ch. XVIII, pp. 250-1.

20 Ibid., Sess. XIV, ch. V, p. 94.

21 Decrees, ed. Tanner, i, p. 245.

22 Chesneau, Paris, i, pp. 30-1.

23 Jean Rousse (curé of Saint Roch in Paris, vicar-general of Orléans and syndic of the curés' assemblies), Extraict des propositions à examiner du livre intitulé 'Deffense du droict épiscopal'; et de la liberté des fidèles, touchant les messes, et les confessions d'obligation (n.p. n.d.), p. 9; Jacques de Vernant, La Defence de l'autorité de N.S.P. le pape, de nosseigneurs les cardinaux, les archévesques et évesques, et de l'employ des religieux mendians. Contre les erreurs de ce temps (Metz 1658), p. 16. 'Vernant' was the pseudonym for the Carmelite Bonaventure de Sainte-Anne or B. d'Hérédie.

24 Canons, ed. Schroeder, Sess. XIII, canon IX, p. 80.

25 Le Pacifique à messieurs les évesques et curez. Pour les religieux (Paris 1625). I have been unable to ascertain the author's identity.

26 Ibid., p. 12.

27 Ibid., p. 18. A similar comment was made by Étienne Binet in his Response aux demandes d'un grand prélat touchant la hiérarchie de l'église, et la juste défense des privilégiés et des réguliers (Nancy 1625), p. 252-3, written on the request of Sébastien Zamet, bishop of Langres, who wished to familiarise himself with the regulars' case. Overall, Binet's response is disappointing, since it does not fully present either party's position but devotes itself to stressing the urgent need for reconciliation.

28 Pacifique, p. 51; Lettre des religieux a monseigneur l'eminentissime cardinal duc de Richelieu (Paris 1632), pp. 25-7; Vernant, Defence, p. 14. 
29 'Overseer' was the precise meaning of the Latin episcopus: W. K. Lowther Clarke, 'The Origins of Episcopacy', in C. Jenkins and K. D. MacKenzie (eds), Episcopacy Ancient and Modern (London 1930), pp. 1-46.

30 Pacifique, pp. 18-34.

31 Ibid., pp. 45-58; Lettre des religieux, p. 25.

32 Pacifique, p. 27.

33 Lécuyer, 'Etapes', 51.

34 Pacifique, p. 29: 'Les Évesques ont pour chef et superieur, le Pape successeur de S. Pierre ... Tous les Apostres ont reçeu les clefs du Royaume des Cieux . . . l'un des douze fut constitué chef . . . Les Apostres [ont reçu] l'ordre et la iurisdiction Episcopale, immediatement de Nostre Seigneur mais les Évesques reçoivent la iurisdiction des Papes.'

35 Ch. 1, pp. 26-8.

36 The question arose in regard to whether the episcopate was a purely human institution, chosen by the supreme governor, or of divine institution: W. D. J. Cargill Thompson, 'Sir Francis Knollys's Campaign against the Iure Divino theory of Episcopacy', in C. Robert Cole and Michael E. Moody (eds), The Dissenting Tradition. Essays for Leland H. Carlson (Athens, Ohio 1975), pp. 39-77; Claire Cross, 'Protestant Attitudes towards Episcopacy in the Early Elizabethan Church', in Vogler (ed.), Miscellanea, pp. 221-8; Peter Lake, Anglicans and Puritans? Presbyteriansim and English Conformist Thought from Whitgift to Hooker (London 1988), pp. 88-97; J. P. Sommerville, 'The Royal Supremacy and Episcopacy “Jure Divino”, 1603 1640', JEH, 34 (1983), 548-58.

37 Given the pro-papal persuasion of Cardinal Du Perron, it might be assumed that his brother held similar views and that, therefore, Pacifique was an authentic representation of these. This, however, can not be verified and the author of the treatise did not state the source of his information.

38 Pacifique, pp. 58-63.

39 Jean Bagot, Défense du droit épiscopal et e la liberté des fidèles touchant les messes et les confessions d'obligation (Paris 1655); Vernant, Defence, pp. 12-13.

40 Vernant, Defence, preface (unpaginated).

41 Ibid., p. 237.

42 Ibid., p. 372.

43 Ibid., p. 399; Lettre des religieux, p. 30.

44 Blet, Le Clergé de France et la monarchie, 2 vols (Rome 1959), ii, p. 235; Rousse, Extraict, p. 3.

45 By 1625, disputes had erupted in Quimper, Orléans, Poitiers, Langres, Paris, Marseille, Chartres and Amiens: Blet, Clergé ... monarchie, i, p. 305.

46 Procès-verbaux, ii, pp. 60-9.

47 Blet, Clergé ... monarchie, i, p. 329.

48 AN, G8*643a, 21 June.

49 Procès-verbaux, ii, pp. 65-7.

50 Ibid., p. 64: 'La charge de prêcher appartenant spécialement à l'Évêque, il est obligé d'y satisfaire le plus souvent qu'il lui sera possible, du moins par ceux qu'il emploiera à cette fonction.'

51 Ibid., p. 63: 'Le choix des personnes qui sont employées à ce ministère, doit particuliérement appartenir à ceux auxquels l'autorité de lier et délier a été donnée de Dieu, qui sont les Évêques.'

52 The Déclaration was reaffirmed by the Assemblies of 1650, 1655 and 1665, again indicating its adoption as the official episcopal policy of the French church and the consistently strong support for its principles.

53 Louis Cellot, De hierarchia et hierarchis (Rouen 1641). See Procès-verbaux, iii, p. 101, for the Assembly's censure. Cellot also argued for the inclusion of regulars in the ecclesiastical hierarchy in virtue of their works of charity as well as their hierarchical activities.

54 Procès-verbaux, iv, pp. 65-71.

55 Ibid., v, p. 249. 
56 Bergin, Episcopate, pp. 675-6.

57 Chesneau, Paris, i, pp. 69-70; Henri Fouqueray, Histoire de la compagnie de Jésus en France des origines à la suppression (1528-1762), 5 vols (Paris 1910-22), v, pp. 44-5.

58 Harlay also forbade the religious to undertake the Easter rituals involving blessed water and candles, ashes, adoration of the cross and palms. He ordered curés to visit monasteries each month in his name to examine the state of the cloisters and observance: AN, L 741, 'Ordonnances de l'archévêque de Rouen', 13 January 1634.

59 Cited in Chesneau, Paris, i, p. 161: 'Vous n'avez pas le droit d'abandonner, de trahir les privilèges . . . vous seriez répréhensibles si vous ne le faisiez pas.'

60 Ibid., pp. 178-9.

61 AN, G8* 648a, 22 September.

62 Chesneau, Paris, i, p. 182.

63 Double patentes de l'ancienne église gallicane, tirées des archives du palais archiepiscopal et du chapitre de l'église métropolitaine et primitialle de Rouen (Gaillon 1643); Acte parfaict hiérarchique, auquel par un concours de la puissance papale avec l'archiépiscopale, les droicts des privilégiez sont conservez et bornez en présence d'un légat (Gaillon 1644).

64 Double patentes, title-page.

65 François de Salignac de La Mothe-Fénelon, Fénelon. Oeuvres, ed. Jacques Le Brun, 2 vols (Paris 1983-97), i, p. 522.

66 Double patentes, pp. 3-5.

67 Acte, p. 8.

68 Double patentes, pp. 8.

69 Procès-verbaux, ii, p. 62: 'non contents de s'être soustraits de la Jurisdiction ordinaire, sous ombre de privileges et exemptions, bien souvent imaginaires et subrepticement obtenues, entreprennent outre cela sur la charge des Évêques et de tous autres Ecclésiastiques, soit pour l'administration des Sacrements, soit pour toutes autres fonctions Ecclésiastiques, qui est en effet renverser l'ordre de l'Église, et ruiner la dignité Episcopale.'

70 Chesneau, Paris, i, p. 81; Lettre des religieux, p. 28.

71 Rousse, Extraict, p. 4. Bagot claimed that only the approbation of the regular's superior was necessary.

72 Anthony Allison, 'Richard Smith, Richelieu and the French Marriage. The Political Context of Smith's Appointment as Bishop for England in 1624', Recusant History, 7 (1964), 164-70.

73 Edward Knott, A Modest Briefe Discussion of Some Points Taught by M. Doctour Kellison in his Treatise of the Ecclesiasticall Hierarchy (n.p. 1630); John Floyd, An Apology of the Holy See Apostolicks Proceeding for the Government of the Catholicks of England during the Tyme of Persecution. With a Defense of a Religious State (Rouen 1630).

74 This fact was noted by Cardinal Bandini in a 1622 memorandum on the wisdom of appointing a bishop for England. He feared that gallican tendencies within the Sorbonne and the French episcopate would encourage anti-regular sentiments among English seculars: Philip Hughes, Rome and the Counter-Reformation in England (London 1942), p. 319.

75 Ibid., pp. 331-2; Allison, 'Marriage', 167-8.

76 An Epistle of the Arch-Bishops Now Assembled at Paris to the Arch-Bishops and Bishops of the Kingdome of France, Concerning the Censure of Two Pamphlets (Paris 1631, reprinted Ilkley 1975), p. 19.

77 The Censure of the Most Illustrious and Most Reverend Father in Christ, the Lord Archbishop of Paris (Paris 1631, reprinted Ilkley 1975).

78 Epistle, pp. 18, 20.

79 Chesneau, Paris, i, p. 120.

80 The signatories requested that the bishops conserve their privileges, indicating their reluctance to surrender their claims and making it unlikely that the quarrel would be settled by this document: AAE, Mémoires et documents. France, 805, fo. 269, 'Déclaration des religieux', 10 April 1632. The Augustinians, Minims, Jesuits, Cordeliers, Capuchins, Jacobins and Carmelites retracted their concession two weeks later: Lettre des religieux. 
81 Jean Orcibal, Jean Duvergier de Hauranne. Abbé de Saint-Cyran et son temps (1581-1638) (Louvain and Paris 1947); Jean Orbical, La Spiritualité de Saint-Cyran avec ses écrits de piété inédits (Paris 1962).

82 Jean Duvergier de Hauranne, Vindiciae censurae facultatis theologiae Parisiensis in Spongiam (Paris 1632); Jean Duvergier de Hauranne, Assertio epistolae, episcoporum in querimoniam (Paris 1632).

83 François Hallier, Defensio ecclesiasticae hierarchiae, seu vindiciae censurae facultatis theologiae Parisiensis, adversus Hermanni Loemelii Spongiam (Paris 1632); Nicolas Le Maistre, Instauratio antiqui episcoporum principatus, et religiosae erga eosdem monarchorum et clericorum omnium observantiae. Cui praemissa est confutatio rationum quas Sorbonicae censurae obiecit Spongia (Paris 1633). For Hallier's career, see Louis Ceyssens, 'François Hallier', Bulletin de l'Institut Historique Belge de Rome, 40 (1969), 157-264.

84 Anthony Allison, 'Richard Smith's Gallican Backers and Jesuit Opponents', Recusant History, 18 (1987), 329-401; 19 (1989), 234-85; 20 (1990), 164-206.

85 Lettre des évêques commissaires généraux du clergé (n.p. 1633). The Assembly also attempted to offer Saint-Cyran a pension for his loyalty. In 1641, it offered 4000 livres for a new edition of his work, copies of which were to be distributed to all bishops. When Chancellor Séguier scuppered this effort by absconding with the newly printed editions, the Assembly was forced to vote fresh funds for a another reprinting! This was successfully carried out and the texts issued: Blet, Clergé . . monarchie, i, p. 441; Martimort, Bossuet, p. 79.

86 Matthew Kellison, $A$ Treatise of the Hierarchie and Divers Orders of the Church against the Anarchie of Calvin (Douai 1629).

87 Duvergier, Assertio, p. 41.

88 Quoted in Orcibal, Duvergier, 622-3.

89 Hallier, Defensio, p. 9-25; Le Maistre, Instauratio, p. 175.

90 Hallier, Defensio, p. 255.

91 Ibid., p. 171: 'Episcopalis potestas in Ecclesia est de iure divin; seu de iure divino est, ut infra summum Pontificem sint aliqui Episcopi, qui particulares Ecclesias regant.'

92 Le Maistre, Instauratio, p. 160.

93 Censures of Certaine Propositions, Partly Drawne out of Ireland, Partly Drawne out of Two English Bookes, where of the First is Intitled A Modest Discussion \&c. the Later An Apologie \&c. Given by the Most Illustrious, and the Most Reverend Archbishop of Paris, as also by the Sacred Facultie of Sorbon (Douai 1631, reprinted Ilkley 1975), p. 91. Many theologians would have disagreed with Floyd's claim that the anointing did not form the matter of the sacrament: Joseph Martos, Doors to the Sacred. A Historical Introduction to Sacraments in the Catholic Church (New York 1982), pp. 218-19.

94 Hallier, Defensio, pp. 97, 113.

95 Duvergier, Vindiciae, p. 92; Le Maistre, Instauratio, p. 188. Floyd countered by claiming that the sense of his assertion was misconstrued by his opponents; the correct meaning was that, of the things necessary to salvation, only ordination could not be supplied when a bishop was absent: Allison, 'Backers' (1987).

96 Censures, p. 106.

97 Hallier, Defensio, p. 585: 'praecellentia status perfectionis Episcopalis, supra statum Religiosae perfectionis'.

98 Ibid., pp. 364 -7; Le Maistre, Instauratio, pp. 79, 225.

99 Orcibal, Duvergier, pp. 249-304.

100 Orcibal, Spiritualité, pp. 25-6. See also Jean Duvergier de Hauranne, Lettre de Messire Iean Du Verger de Hauranne, abbé de St Cyran: à un ecclésiastique de ses amis. Touchant les dispositions à la prêstrise (n.p. 1647), p. 33.

101 Duvergier de Hauranne, Lettre de Messire, p. 52: 'par l'obeissance qu'il voue à l'Évesque pour toute sa vie ... cette obeissance estant rendue à Iesus-Christ resuscité que l'Évesque représente lors qu'il consacre un Prêstre; ie dois avoir la mêsme soumission au commandement de l'Évesque, qu'au commandement de Iesus-Christ'. 
102 Ch. 2, pp. 63-4.

103 Duvergier, Vindiciae, pp. 135-7.

104 Orcibal, Spiritualité, p. 231.

105 Hallier, Defensio, pp. 678-9.

106 Golden, Rebellion, pp. 69-75.

107 Pierre Morestel, Le Guidon des prélats et bouclier des pasteurs (Paris 1634).

108 Arrest celebre du Conseil d'Estat, par lequel il est declaré que ceux qui destruisent la hiérarchie, sapent les fondemens de la monarchie (Gaillon 1634).

109 The curés maintained that the droit de visite (procuratio) consisted only of vivres and refused to give money as well as hospitality: Morestel, Guidon, pp. 265, 301; André Chrestian, Replique pour les curéz du diocèse de Rouen. À la response de Maistre Adrian Behotte chanoine et archidiacre en l'église de Rouen. Touchant le prétendu droict de visite des archidiacres (Rouen 1628).

110 Morestel, Guidon, pp. 371, 392, 531.

111 Ibid., pp. 333-55.

112 Ibid., p. 28.

113 Ibid., p. 18.

114 Ibid., pp. 355-6. Morestel quoted from Gerson's Tractatus de consiliis evangeliis et statu perfectionis, part iii.

115 Morestel, Guidon, p. 521.

116 Ch. 3, n. 76.

117 Nicolas Mazure, L'Obligation des fidèles de se confesser à leur curé, pour respondre aux réflexions des réguliers sur le chapitre 21 du concile générale de Latran IV, tenu en l'année 1215, sous le pape Innocent III (Paris 1653). Mazure was curé of the parish of Saint-Paul.

118 Georges Pirot, L'Apologie pour les casuistes contre les calomnies des Jansénistes (Paris 1657) ; Golden, Rebellion, pp. 81-6.

119 Godfroy Hermant, Mémoires de Godefroy Hermant, sur l'histoire ecclésiastique du xviie siècle (1630-1663), 6 vols (Paris 1905-10), iii, p. 171.

120 Bonichon published three tracts during the dispute, all containing identical arguments: Défense des ordonnances de monseigneur l'évesque d'Angers et de l'authorité épiscopale contre deux libelles (Angers 1656); Extrait des principales faussetz mises par l'autheur des Réflexions sur le livre de la Deffense des ordonnances de monseigneur L'évesque d'Angers (Angers 1657); L'Authorité épiscopale défendue contre les entreprises de quelques réguliers mendiants du diocèse d'Angers sur la hiérarchie ecclésiastique (Angers 1658).

121 Bonnot, Arnauld, pp. 252-70.

122 Bonichon, Authorité, pp. 13-14, 23.

123 This was inaccurate. Several pre-Tridentine popes had done precisely this.

124 Ibid., pp. 117-18.

125 Bonichon, Authorité, pp. 192-250, 566, 571-5; Bonichon, Défense, pp. 7, 102, 161.

126 Bonichon, Authorité, pp. 598-99; Bonichon, Défense, p. 102.

127 Michel François David, Lettre envoyée à moneigneur le reverendissime archévesque de Rouen, primate de Normandie, \&c. (Rouen 1620), pp. 8-11. David was curé of Saint Romain de Colboc.

128 Bonichon, Authorité, pp. 28-33.

129 Pascoe, Gerson, pp. 150-2.

130 BN, Ms. Fr. 24075 (register of the assemblies of the curés), fos 29-30.

131 Bonichon, Authorité, epistle (unpaginated).

132 Ibid., p. 15.

133 Morestel, Guidon, p. 52: 'Car le peuple se tourne promptement et se conforme facilement à la nature de son Prélat.'

134 Bonichon, Authorité, p. 23; Extrait des quelques maximes de l'Anonyme, intitulé L'Obligation des fidèlles, et c. et de quelques-uns de ses sentimens; principalement contre l'authorité du pape et des Évesques (n.p. n.d.), p. 22.

135 Morestel, Guidon, 'Addresse aux messieurs les reverends prélats' (unpaginated); Bonichon, Authorité, preface (unpaginated). 
136 Morestel, Guidon, p. 98: 'En choses donc qui sont inutiles à l'Église, ou qui repugnent directement ou indirectement à la loy de Dieu et don son Église, [nous] ne sont obligez d'obeir aux Prélats.'

137 Bonichon, L'Authorité, pp. 165, 539.

138 The Assembly issued a circulatory letter to all bishops in 1656 which endorsed the episcopal prerogatives expressed by Bonichon, without reference to his view of curés' rights. It condemned the 'errors' of those regulars who opposed Arnauld and ordered that they retract their claims: Lettre de l'assemblée générale du clergé de France (n.p. 1656), pp. 1-3.

139 Including the archbishop of Sens and the bishops of Nevers, Beauvais, Evreux and Lisieux: Jean Mesnard, 'La Collaboration des écrivains de Port-Royal aux censures', Chroniques de Port-Royal. Actes du colloque tenu à Alet (Paris 1982), pp. 3-20.

140 Camus, Unite, p. 144; Camus, Considérations, pp. 143-4.

141 Ibid., pp. 165-6, 752.

142 The Assembly's circular letter to all bishops is printed in Procès-verbaux, v, pp. 247-50, and can also be found in BN, Mélanges de Colbert, 7, fos 254-61. It also censured Jean Rousse, Sommaire des déclarations des curez de Paris: sur le vray sens des onze propositions, extraictes et obiectées contre le livre intitulé, 'De l'obligation des fidèles de se confesser à leur curé.' Contenant au fond la definition, les qualités, et fonctions du propre prestre (n.p. 1657), which had summarised Mazure's work and reiterated the doctrines of curial droit divin and control of parish affairs; see Procès-verbaux, iv, pp. 221-3.

143 The articles were finally published in circulars sent to every bishop. See ch. 4, p. 116ff, for discussion of the episcopate's negotiations with the papacy on this matter.

144 Recueil des actes, $i$, cols 687-8: 'Les fidèles peuvent se confesser en assurance et fort utilement aux réguliers privilegiez par le Pape, lorsque les Évêques par leur approbation les ont rendus idoines et habiles pour cette fonction dans leurs Diocèse, comme parle le Concile de Trente.'

145 Ch. 2, p. 60.

146 Missionaries in Canada were directly subject to the papacy until 1659. The 1665 Assembly also commissioned a new edition of the 1625 Déclaration: Jean Gerbais, Ordinationes universi cleri gallicani circa regulares conditae, primum in comitiis generalibus anni 1625 (Paris 1665).

147 The Capuchins, Augustinians, Jesuits, Carmelites and Minims: Pierre Blet, Les assemblées de clergé et Louis XIV de 1670 à 1693 (Rome 1972), pp. 34-65.

148 Recueil des actes, iii, cols 1002-70.

149 Pierre Blet, Le Clergé de France, Louis XIV et le saint siège de 1695 à 1715 (Rome 1989), pp. 336; Robin Briggs, Early Modern France, 1560-1715 (Oxford, 2nd edition 1998), p. 147.

150 Appels comme d'abus remained possible. Further discussion of the edict is contained in ch. 5 , pp. 157-8. The edict is printed in Recueil général des anciennes lois françaises depuis lan 420 jusqu'à la Révolution de 1789, ed. François-André Isambert, 29 vols (Paris 1821-33), xx, pp. 245-9 ; Procès-verbaux, vi, pp. 230-1. 


\section{4 \\ Ecclesiastical monarchy or monarchies?}

Why did the French episcopate prove so tenacious in opposing the regulars' calls for independence through the seventeenth century? Like the bishops' quarrels with the curés, these were crises of authority in which the episcopate fought to assert its disciplinary supremacy over the religious orders. Yet the struggle between the bishops and the regulars was just one manifestation of a much larger complexity: the place of the episcopate in the church's governing hierarchy. Not only did the bishops have to define their relationship with the lower clergy; they also had to characterise and then defend their understanding of the links between episcopacy and the supreme headship of the earthly church. As two of the major offices of the church, the episcopate and the pope had to interact routinely if the church was to function smoothly. But this intercourse carried the risks of rivalry and disagreement, and more often than not that was precisely how it evolved over the course of the century. Whenever the pope strayed into the French church, he tended to raise the hackles of its 'perfidious' and 'turbulent' bishops, and to leave his supporters feeling that the authority of 'His Sanctity [is] ruined in this realm'. ' Contested boundaries offered fertile ground for the growth of suspicion, resentment and outright controversy.

To a large extent, the disputes among the bishops, the papacy and the lower clergy represented three competing conceptions of the church, and crystallised opposing views of ecclesiastical government, discipline and hierarchy at local, national and international levels. Each party based its conceptions on the traditional notion that the church was a hierarchy of orders, but they immediately parted company when they described the individual components of this structure. Both the regulars and the papacy favoured a broadly conceived system of subdivided hierarchy, whose distinct sections were connected by their common obedience to the pope. This obligation of obedience to the pope meant that, in one sense, theirs was a vertical hierarchy of government. Yet within that all-embracing hierarchical frame, two attenuated hierarchies existed simultaneously, one containing the pope and the episcopate and the 
other housing the pope and the regulars. Jean-Pierre Camus certainly recognised the consequences of that possibility, and pointed it out to his fellow bishops in treatises that he wrote specifically to defend their authority. If the regulars were exempt from episcopal jurisdiction in their hierarchical functions, he observed, then two fragmented hierarchies existed in the church. That was an intolerable situation if the interests of ecclesiastical order and unity were to be served. ${ }^{2}$ Antoine Godeau was just as adamant that it would be a 'monstrosity' to see regulars independent 'of the bishops who are their heads'. That was precisely what they sought, he complained, when they gloried in offending against 'all their ordinances'.

Did the regulars' propose a de facto presbyterianism which, for all practical purposes, eliminated the episcopate from the church $?^{4}$ It might appear so, were it not for two facts. First, they defended the unrestricted and inalienable authority of the pope as the universal bishop; second, they did not eliminate the bishop's jurisdictional role entirely, but merely that over them. The curés' doctrine, on the other hand, smacked far more of presbyterianism. They were parish priests, governing territories which together made up a bishop's diocese. When they refused to allow a bishop to intervene in their parishes, they neutralised his influence through most of his see. Their hierarchical model broke all governmental links between bishops and parish priests because, while it admitted an honorific hierarchy in which bishops preceded curés, it made no allowance for a hierarchy of jurisdiction to distinguish bishops, curés and the pope. Instead, each existed and functioned autonomously, periodically uniting to deliberate in synods and councils. It was the curés who gained most from this arrangement, for theirs was a hierarchy that, paradoxically, placed bishops and parish priests on an equal jurisdictional footing. However, it was an ecclesiological model that could not accommodate the episcopate's understanding of hierarchy and jurisdiction. For in its linear version of the ecclesiastical hierarchy, bishops preceded all other priests in both honour and jurisdiction. The higher the office in the hierarchy, the greater its prestige and its governmental power. This was certainly an uncompromisingly vertical construction, but it was just as inflexible as those of its opponents. As a result, it was bound to provoke struggles not only between the bishops and the lower clergy, but also between the episcopate and Rome.

The episcopate's quarrels with the regulars certainly spotlighted the discrepancies between its opinion of the episcopal-papal relationship and the view proposed by the regulars and the papacy. However, the problem of contested jurisdiction was also periodically manifested in others ways. Among the key privileges or liberties valued by the episcopate was a bishop's right to be judged by his peers in the first instance. Almost every decade from the 1620s was punctuated by a struggle between the French episcopate and the papacy over 
this issue, and each case saw the bishops unite in opposition against what they considered to be the papacy's audacious incursions into their jurisdictional territory. In all these episodes, the episcopate achieved its immediate aims, which were to prevent the papacy from setting a precedent for judgements of bishops and to protect and enhance episcopal dignity. Although the cases might differ materially, the same principles were at stake in all.

Because it related directly to their dearly held gallican liberties, this was an issue of chronic significance for French bishops, and their stance towards it reveals a great deal about their perception of their office, status and functions within the Catholic church. When members of the episcopate referred to their order's gallican privileges, they had in mind very specific aspects of the extensive body of French liberties which had emerged during previous centuries. At a basic level, gallicanism is usually explained as either political or ecclesiastical: the term 'political gallicanism' describes the alliance between church and state to limit papal authority, while ecclesiastical gallicanism is characterised by the belief that the French church should be independent of both king and pope. A more particular application subdivides ecclesiastical gallicanism, however, according to the institutional structures of the French church, so that the specific term 'episcopal gallicanism', in part, represents the special privileges or liberties pertaining to the office of bishop. These privileges were thought to have evolved since the time of the early church, and their defenders were fond of tracing them to their origins in order to defend their legitimacy. ${ }^{5}$ Equally, however, episcopal gallicanism was characterised by a tough defence of episcopal rights of jurisdiction, so that the bishops' rejection of illegitimate papal intervention within their dioceses should be at least partly understood as a manifestation of their gallicanism.

The bishops possessed a finely tuned interpretation of papal and episcopal duties and rights. Throughout the century, they accepted the traditional doctrine that the pope was the 'bishop of bishops' and, as Christ's vicar on earth, the leader of the universal Catholic church. ${ }^{6}$ Even at the height of gallican sentiment during the 1680s, Bishop Bossuet was careful to stress papal primacy within the church; although this might not extend to papal infallibility in matters of dogma, the pope was certainly 'first bishop', successor of Peter and deserving of respect. $^{7}$ Yet the bishops, the papacy and regulars diverged on the exact character of this primacy. The bishops never denied that the pope could issue pastoral privileges to regulars. However, they felt justified in refusing to accept those which they regarded as suspect or unsuitable for diocesan requirements. In their view, no ecclesiastical power was entitled to exercise jurisdiction within dioceses without the approval of the governing bishop.

French bishops were not the first to encounter the occupational hazards of functioning as a bishop in a system whose key players held markedly different 
interpretations of their role and status. The delegates at Trent hit on the potential for confusion and disagreement when they argued over droit divin, but after the Council, reforming bishops also ran into difficulties when they set out to place their office at the heart of diocesan affairs. This was the tenor set by Trent, but it proved rather stickier in practice than on paper. Very soon, the loops of episcopal and Roman jurisdiction overlapped, and where they did, bishops and Rome sometimes competed for supremacy. Even Charles Borromeo, the quintessential reforming bishop, clashed swords with the papacy when it sought to assert its authority over his archiepiscopal administration. On several occasions, the archbishop became exasperated with Rome's willingness to quash or alter his regulations. First, it vetoed his plan to re-introduce the Ambrosian liturgical rite to Milan on the basis that it was a hostile attempt to distinguish the Milanese archbishopric from Rome. More seriously, the statutes of Borromeo's fourth provincial council received a thorough revamping when he sent them to Rome for approval in $1578 .^{8}$ The archbishop was furious when he found that the Congregation of the Council was in the process of censuring rules that were entirely in accord with Trent's decrees. Worse, Rome then ordered that the Council's edicts be suspended in the archdiocese until further notice. The wound was healed only when Borromeo travelled to Rome to remonstrate with Gregory XIII, who, after he had personally studied the decrees, approved them in their entirety.'

Borromeo's personal reputation as a famously zealous reformer and his membership of a well-connected Roman ecclesiastical family surely contributed to this resounding victory for his archiepiscopal initiative and authority. The affair bears some comparison with the experience of François de Sourdis, who decided to emulate Borromeo by convening his own provincial council in Bordeaux forty-six years later. The contrasts between the two incidents, however, are just as significant: unlike Borromeo, Sourdis had no satisfaction when Rome took scissors to his decrees. After presiding over his council in 1624, he presented its statutes to the Assembly the following year. It received them enthusiastically and immediately approved them. In fact, the council caused quite a stir in the episcopate; Sourdis was feted for his reforming initiative and congratulated for his rigorous efforts to control regulars through legislation. Even propapal prelates like Léonard Destrappes of Auch were among those who wrote him complimentary letters. ${ }^{10}$

As canonical custom dictated, Sourdis forwarded the decrees to Rome soon after the council dissolved, even publishing and circulating numerous copies of the decrees in anticipation of the papal seal of approval. ${ }^{11}$ The decrees demonstrated precisely the same belief that underpinned the 1625 Déclaration sur les réguliers: the only viable means of achieving reform was through supporting and extending the authority of bishops so that regulars were entirely under their control. In defending his council, Sourdis was careful to point out that 
these were reasonable sentiments, upheld by eminent theologians, canonical doctrine and church practice. But Rome censured the decrees for the very reason that the episcopate praised them. Its primacy objection was that Sourdis had completely failed to use the Tridentine phrase that described the bishop as a delegatus apostolica sedis with authority to visit the houses and monasteries of religious. Privileges were also a problem: the council stipulated that diocesan bishops were annually to visit monasteries whose members were not grouped in general or provincial congregations or where the rule was not observed, regardless of privileges. Several decrees ordered the faithful to receive paschal communion and confession from their parish priests, again overriding the regulars' privileges. ${ }^{12}$

Armed with a keen sense of episcopal status, the council of Bordeaux amputated the phrase tamquam delegatus apostolica sedis to allow bishops proper pontifical power over the discipline of regulars. ${ }^{13}$ There is no doubt that Sourdis distorted Trent's legislation, for he must have realised the significance of this particular safety net for the papacy. But its daring omission from Bordeaux's decrees was a conscious affirmation of the belief that bishops did not govern dioceses as papal delegates, but by virtue of the jurisdictional power inherent in their office. It was hardly surprising that Rome refused to approve the decrees. Did Sourdis prompt its reaction purposely, therefore, in order to engineer a confrontation? It appears not, for after pleading his cause in letters to Rome, he finally accepted that the council's statutes would remain a dead letter to the papacy. The exultation that had prompted his unrealistic expectation that the decrees would triumph in Rome then turned to disillusionment and bitterness.

The papacy, as Sourdis assumed, used his council to flex its authoritative muscles over the archbishop, Bordeaux's bishops and their local churches: its revision of the decrees reinforced its authority over all three in word and deed. Of course, the papacy did have legitimate fears, for the decrees enhanced episcopal control at its expense. It did not help that the Assembly produced its uncompromising Déclaration against the regulars at precisely the time when the papal congregation was examining Sourdis's legislation and, indeed, the nuncio actually criticised the archbishop for his participation in the deliberations that produced it. ${ }^{14}$ The bonfire had now been ignited, however: the regulars showed few signs of abandoning their campaign; the episcopate was growing increasingly disgruntled with both the regulars and the papacy; it had access to a potent medieval tradition of gallican independence in which to embed its displeasure; finally, in the Assembly, the bishops had an officially constituted forum from which they could launch concerted attacks on Roman hegemony and regular impudence.

In 1635, as part of the episcopal campaign to quash the anti-Smith regulars, the Assembly sought the Roman stamp of approval for the Déclaration sur les 
réguliers. But, once again, the pope withheld his validation, surely hoping that the bishops would simply give in without a fight. So important were these regulations in the episcopate's eyes, however, that it refused to allow the document simply to languish in limbo. Seizing the initiative, the 1645 Assembly published the regulations, no doubt in the dawning awareness that papal endorsement would not be forthcoming then or in the future. In fact, it had never been likely that Rome would approve decrees that so trenchantly defended episcopal authority at the expense of papal authority. Successive popes perceived the Déclaration as an act of serious disobedience by French bishops, especially since the episcopate presented it as a piece of finalised legislation rather than as a catalogue of suggestions which would respectfully await papal ratification before adoption. ${ }^{15}$ In 1625, Nuncio Spada anticipated this complaint and sought to avoid a rift between Rome and the episcopate by urging the bishops to present the regulations as a supplication or a project, rather than as a fait accompli. ${ }^{16}$ They ignored that compromise at every stage of the Déclaration's troubled history, however, because it suggested that papal approval was necessary before disciplinary legislation formulated by the French episcopate and intended for the French church could have force of ecclesiastical law. Finally, goaded by what it perceived as persistent plots to undermine its legitimate authority in Orléans, Rouen, Bordeaux and elsewhere, and by Rome's continued reluctance to support its reform programmes, the episcopate published the articles independently.

When the archbishop of Toulouse, Charles de Montchal, addressed the 1635 Assembly, he defended the Déclaration by claiming that it contained nothing contrary to Trent and sought only to ensure the respect and obedience of regulars for the bishops, their paternal superiors. ${ }^{17}$ In their efforts to control the regulars, the bishops always believed that they acted according to the spirit of the Council, though even they realised that they did not always act to its exact letter. Yet that was their prerogative for, as bishops, they had the right to interpret and expand Trent's reform decrees (or indeed, logically, those of any other council) according to its 'spirit'. ${ }^{18}$ This was precisely, the episcopate argued, what it had done in producing the Déclaration. It is not surprising, then, that it remained the yardstick for episcopal-regular relations throughout the century: seventy-five years after the articles were first introduced into the Assembly, Bossuet would refer to their 'most wise' rules, and exhort his fellow bishops to see to their execution. ${ }^{19}$

There was a disquieting correspondence between the regulations of the council of 1624 and the Déclaration of 1625 that made the papacy very uneasy. Both expressly confirmed that bishops held sole control in their dioceses. Even more significantly, they implied that bishops were not beholden to the pope for their jurisdiction. Yet these propositions were expressed in statutes that never used the words de droit divin. Those individual bishops who became embroiled 
in disputes with the regulars during the first half of the century, like Guillaume Le Prestre, Harlay and Henri de Sourdis, displayed the same circumspection. None of them mentioned the uncompromising term de droit divin, although their stance undoubtedly reflected what it signified. ${ }^{20}$ Yet even during the 1630s, when Saint-Cyran, Hallier and Le Maistre boldly shouted from the rooftops that bishops possessed their jurisdiction de droit divin, the episcopate coyly refrained from joining them openly, despite provocation from English and French regulars. No doubt fearing the issue's controversial nature and concerned with the adverse reaction from Rome if the French episcopate officially endorsed the droit divin theory of episcopal jurisdiction, the bishops contented themselves with discreetly supporting those writers who explicitly affirmed it in their defences of episcopacy.

The episcopate's prudent discretion evaporated in the 1650s. In their view, successive regulars appeared ever more brazen in their willingness to defy established forms of ecclesiastical discipline. There was also the growing menace posed by the curés' Richerist doctrines and, to make an unstable situation even more complicated, the tangled case of Cardinal de Retz, archbishop of Paris and notorious Frondeur. Without the motivation provided by this episode, it is likely that the bishops would have continued to avoid expressly addressing the issue of droit divin, but its occurrence contemporaneously with the regular and curial challenge jolted them into concerted action.

The Retz affair ensnared both crown and church, and was not ultimately resolved until the archbishop resigned his see in 1662, to the government's evident relief. Throughout the 1650s, Retz defied the Mazarin administration, an extension of his opposition to the crown during the Fronde. Then, he had led one faction of the anti-Mazarin nobility, but his greatest contribution to events, and perhaps the talent most feared by Mazarin, had been his ability to whip up popular sentiment against the government through fiery sermons. To neutralise Retz's influence, the government first offered him an ambassadorship in Rome. When this did not tempt him, it resolved upon harsher measures, imprisoning the cardinal in the Vincennes and signalling its intention to try him for his allegedly treasonous crimes. Among the clergy, only the Parisian curés reacted vigorously against the arrest of Retz, their vicar-general. The bishops, in particular, were almost quiescent; even Jean-François de Gondi, the cardinal's uncle and archbishop of Paris, was half-hearted in his calls for Retz's release. ${ }^{21}$ Perhaps the episcopate might have held its silence if events had not taken a more complicated turn when Gondi died in March 1654 and Retz immediately succeeded to the archbishopric of Paris. He was recognised by the episcopate, as well as by the papacy, his diocesan chapter and his curés, as the legitimate archbishop of this illustrious see; only the crown 
refused to endorse Retz's appointment, and it persevered with its plan to bring him to trial before its courts.

At this point, the question of Retz's trial assumed an altogether different and more alarming hue, quickly involving those who were suddenly his fellow bishops. Essentially, at issue for them was whether Retz, as an archbishop, could be judged by a secular court. Immediately, the episcopate declared that he could not, citing his ecclesiastical immunity. But a related problem quickly emerged when, bowing to pressure from the French crown, Alexander VII issued a brief appointing a suffragan bishop to the see of Paris in 1655. ${ }^{22}$ The episcopate reacted swiftly. Supported by his colleagues, Dominique Séguier of Meaux, the bishop chosen for the post by the government, refused to accept the nomination and Mazarin was forced to capitulate and to allow Retz to choose a vicar-general from a list presented by the court. ${ }^{23}$

For the French episcopate, this attempt to appoint a suffragan to Paris without the consent of the current incumbent was absolutely insupportable. It channelled its opposition through the 1655 Assembly of Clergy, which, when it met in November, quickly became the forum for heated denunciations of the papal brief. 'No greater diminution of episcopal authority' was possible, declared the bishop of Limoges, François de La Fayette, to his fellow deputies. The Assembly's president, Claude de Rebé of Narbonne, denounced the brief as an 'abyss' that destroyed all episcopal authority, and implied that if this infraction slipped past the episcopate, then it would be difficult, if not impossible, to withstand future violations of its kind. ${ }^{24}$ According to the bishops, the pope had no power to interfere in the government of a diocese without its prelate's consent, and in this instance Retz obviously had not supplied his approval.

Once Retz had been allowed to choose his vicar-general and thereby been accorded his right as archbishop, the episcopate dropped its interest in this aspect of his predicament. Yet, the core issue of episcopal jurisdiction remained in the foreground of ecclesiastical debate in the later 1650s, though in reference to fresh circumstances. In 1653, Jean Bagot and Nicolas Mazure published their justifications of regular and curial jurisdictional independence respectively. With the papal encroachment on Retz's episcopal authority still fresh in their minds and feeling the assault on their perceived jurisdictional rights from three clerical angles, the bishops felt obliged to state positively that which they believed to be their true position in their twelve articles of 1657 . Recognising the danger, Rome steadfastly opposed the episcopate's efforts to publish its articles as the definitive policy of the French church. Playing on Mazarin's fear that his fragile alliance with Rome against the Jansenists would be sundered and any hope of bringing Retz to judgement scuppered if the articles were published, it even managed to enlist the government's help in torpedoing them..$^{25}$ 
Despite this wall of formidable opponents, the episcopate struggled for four months to publish its doctrine and it finally succeeded in doing so. That tenacity reveals the threat which the bishops felt to be posed by the concerted attacks of their opponents. Alain de Solminihac, bishop of Cahors, deftly summarised these when he noted that prelates were the masters and regulars the disciples; it was, therefore, bishops who should govern the actions of religious. ${ }^{26}$ The example of Solminihac, often identified as a prelate of unshakeable ultramontane beliefs, ${ }^{27}$ illustrates the important point that even bishops who were initially quite papalist in their attitudes towards episcopacy could and did move towards a more independent and authoritarian stance as a result of regular opposition to their reforming will, even if they did not explicitly affirm the verity of jurisdictional droit divin. Despite having once been an Augustinian canon, Solminihac could not condone regular resistance to episcopal will within dioceses, and the evidence does not suggest that other bishops who were members of religious orders believed otherwise.

Likewise, Henri de Sponde, bishop of Pamiers, passed his pre-episcopal career as a scholar in Rome, where he professed classic pro-papal views in his historical works defending the theological and politico-religious rights of the papacy. ${ }^{28}$ His experience of episcopal life, however, increasingly drew him to assert the rights of bishops towards regulars and the pope. From 1626, the bishop was involved in a wearisome dispute with the Capuchins of his diocese, who claimed papal privileges for their pastoral cares, and he consistently condemned their rebellious conduct. His frustration is all too evident in his 1635 ad limina report to Rome, which let loose a volley of bitter accusations against the friars. In a tone that could only have raised eyebrows in Rome, the bishop described how they displayed no respect for his authority and were 'scathing, violent and critical' towards the secular clergy. Most particularly, '[their] pride hides itself under such humble clothes. They always put forward their apostolic privileges ... the right to give paschal communion, which seems to rest only with the poor parish priests, is no longer protected from their usurpation.' Worst of all, this kind of behaviour made a mockery of their bishop, and potentially exposed him to the ridicule of his laity. ${ }^{29}$ Despite his despair however, Sponde gradually extended some control over the recalcitrant Capuchins. Five years later, he wrote to Rome that the order's superiors were 'more docile and obedient' and that his disciplinary measures against the order had been 'an excellent remedy'. But, he concluded, these tactics required persistence on the part of bishops if they were to ensure success. ${ }^{30}$ With this kind of draining experience, it is unsurprising that Sponde's career displayed a movement from ultramontanism towards a stance which defended the independent jurisdiction and rights of bishops.

That attitude was perfectly evidenced when the 1657 articles delineated the jurisdictional boundaries between bishops and the papacy. To counteract 
the papacy's infuriating tendency to ignore those limits, they stated that 'The bishops, successors of the Apostles, are established by Jesus Christ in his church ... they receive their jurisdiction immediately from him for the spiritual regime and government of their churches, of which they are the leaders by divine law with subordination to our holy father the pope ... they are the fathers, pastors and doctors of all the faithful who are in their dioceses. ${ }^{{ }_{31}}$ Simultaneously, the articles accepted that the pope held his jurisdiction immediately from Christ. Yet the episcopate saw no contradiction between these two claims. The author of the articles, Pierre de Bertier, pointed out to his colleagues that, since the bishops' powers of order and jurisdiction were granted by Christ, they were not vicars of any ecclesiastical power on earth. The pope's authority also issued directly from Christ, and it gave him special rights over bishops: he appointed prelates and gave them their subjects; certain causes were reserved to his judgement; he reigned within the church as supreme head to whom canonical obedience was essential. ${ }^{32}$ Yet papal authority did not extend to interfering in the government of bishops without their agreement, despite the regulars' insistence to the contrary and despite the pope's attempts to do so in the case of Retz.

A century after the Council of Trent, therefore, the French hierarchy moved to proclaim episcopal droit divin as the official position of the French church. After Bertier read the articles in session, the Assembly prepared to sign them, adding an order that bishops forbid support for the contrary doctrine and condemn those books in which it was currently espoused. Without doubt, this was a momentous step, and testified to the strain that repeated squabbles over jurisdiction had produced. Never before had the episcopate felt obliged, as a unit, to endorse publicly the doctrine of its droit divin, though at least one member of its rank had firmly nailed his colours to the mast almost two decades before. Jean-Pierre Camus, dogged defender of the episcopal office, had judiciously invoked the revered François de Sales to lend added legitimacy to the disputed theory, recalling how de Sales had advised a non-resident bishop that his pastoral obligations were held de droit divin and must, therefore, be fulfilled through conscientious, constant administration. ${ }^{3}$

This was, of course, a clever ploy, given the esteem in which de Sales was held within the French church; the implication was that a doctrine endorsed by someone as learned and holy as the bishop of Geneva had to be entirely orthodox and correct. The ramifications of this position on the droit divin of episcopal jurisdiction were unmistakable; because the pope did not grant bishops their power of jurisdiction, he could not interfere in their dioceses. The religious' claim of papal privileges was also, by default, completely null. Instead, the bishop could accept these if he wished but if, in his wisdom, he chose not to do so, then this was his prerogative. ${ }^{34}$ Yet for a single bishop to support this claim 
in public was quite different from a push by his brethren to proclaim it as the official and only position of the French church; it was far easier for the episcopate to distance itself from the opinion of one of its members, should this become necessary, than to retract an opinion expressed officially on behalf of all.

The papacy hardly needed Camus to identify the implications of episcopal droit divin for the range of its authority. Nuncio Piccolomini brought all his diplomatic skills into play as he urged Mazarin to suppress the articles, in order to prevent potentially devastating rifts between Rome, the French government and the French church. The episcopate was initially immovable but, following negotiations, it grudgingly offered to suppress the regulation obliging universal adherence to the doctrine of episcopal droit divin, on the grounds that it remained a matter of contention within the general church. Lively debates then ensued between court prelates, including Marca of Toulouse and Cohon of Nîmes, who eventually rallied to support the government, and those prelates, including Bertier and Gondrin, who still wished to publish the document. ${ }^{35}$ Under pressure, the prelates abandoned the articles only with great reluctance, and a vote was taken to suppress the works of Bagot and Mazure. Yet the affair was still not over. Under the influence of Bertier and Gondrin, the Assembly published a circular to be sent to each diocese. In this, the actual articles declaring episcopal jurisdiction to be held by droit divin were replaced by a relation of the Assembly's discussions, but their ideas remained in written form as the expressed doctrine of the French clergy. Signed and approved by the deputies, the circular was even entered in the official procès-verbal. Mazarin, however, had the last word when he subsequently ordered the Assembly's agents to delete the declaration. ${ }^{36}$ Yet despite this particular victory, the actions of the bishops throughout the battle, their fury at Rome's attempts to encroach on their jurisdiction and dignity, and their sustained efforts to proclaim their jurisdictional droit divin officially reveal their wishes and beliefs. In 1657, they for the first time explicitly demonstrated their adherence to this provocative, but rewarding, theory of episcopal power.

On the other hand, the episcopate was foiled in its plan to locate episcopal droit divin as the only legitimate position of the French church. It was not able to achieve this at any stage, though it would continue to demonstrate its adherence to it in the wake of the crisis in 1657 and to challenge papal incursions into what it regarded as its jurisdictional realm. This was made perfectly clear when the articles were applied to Canada in 1665, and when Claude Joly wrote to the Conseil du Roi some years later to defend his actions in his dispute with the regulars of Agen. Joly argued that bishops possessed 'by divine law the power to give permission to those priests that they might choose to aid them in these sacred ministries, to preach, to confess and to absolve, as also to revoke this permission when they find it opportune'. ${ }^{37}$ This bold claim had 
never been expressly stated by any seventeenth-century prelate before 1657; the bishops' actions in 1657 had made a profound impact on Bishop Joly.

Joly's appeal produced an arrêt vindicating his behaviour in Agen.$^{38}$ However, the king then switched tack to propose that a papal bull be promulgated which would assuage Roman sensitivities, confirm the policy enshrined in the arrêt, and resolve this recurring quarrel once and for all. ${ }^{39}$ The papacy was happy to publish the bull, Superna magni patrisfamilias praeordinatione, but it did not take the episcopate long to work out why. Although the bull ordered regulars to submit to their bishops' authority, it did so by representing bishops as delegates of the holy see. Since this was no more than an expression of Rome's traditional position on papal and episcopal power, the bull could do nothing to breach the steadily widening divisions between the episcopate and the papacy. Unlike their Spanish and Portuguese counterparts, French prelates never defended their attempts to introduce hierarchical discipline among regulars on the basis of apostolic delegation, but preferred to rely solely on the dignity and jurisdictional rights inherent in their office. ${ }^{40}$ The bull, therefore, did not offer them nearly enough ground for their taste, and they were quick to express their dissatisfaction as soon as its contents became known. The coadjutor bishop of Reims, Charles-Maurice Le Tellier, took the opportunity to produce a memoir for the king's benefit, in which he summarised the bishops' antipathy towards the bull by outlining their customary reasons for rejecting the regulars' papal privileges. The bull was, he wrote, 'contrary to the maxims received in the church of France' and a 'wound' to episcopal authority. The only effective solution would be its revocation in favour of a bull that conformed to Trent's decrees and vindicated the bishops' power over regulars. ${ }^{41}$ Yet Rome was unlikely to choose this moment to abandon its perceived rights, and with the bishops still sticking to their own uncompromising views, it was only royal brokerage that forestalled a full-scale war between them. Eventually, individual prelates allowed regulars to use their privileges during the Easter season without specifying under whose direct authority they did so. ${ }^{42}$

Unusually, this particular quarrel ended rather inconclusively, without either the bishop or the regulars capitulating in Agen. But, crucially, the bishops were to have the final say in the troubled episcopal-papal equation when they won the 1695 edict from Louis's government. There was no mention of papal delegation in the rules which placed the regulars under episcopal jurisdiction, for this would have incensed the episcopate, as in the case of Superna some years before. The edict presented an image of episcopacy which was wholly in line with the bishops' conception of their relationship with the lower clergy and with the pope, and with the legislation of 1625 and $1657 . .^{43}$

The development of this position owed a good deal to the ideas of contemporary French reformers, for the episcopate's endorsement of jurisdictional 
droit divin provides a remarkable example of the transmission of the reformers' views on episcopal dignity and authority. It is not a coincidence that Olier delivered his 'Projet', with its finely evolved view of episcopacy, to the Assembly in 1651, shortly before the episcopate produced its most explicit definition of the jurisdictional relationships linking bishops, the pope, regulars and curés. The reformers' emphasis on the perfection and elevated rank of the episcopal state and their persistent call for obedience to the will of bishops not only encouraged French prelates to reflect on their office but called forth the confident expression of their views against the enemies of their authority and ecclesiastical condition. Whatever bolstered episcopal prestige and power and provided coherent ideas on the nature and function of episcopacy was certain to appeal to an episcopate which saw itself under sustained attack from the lower clergy and the papacy. Although Bérulle and his disciples did not directly concern themselves with the jurisdictional relationship between prelates and the pope, they laid the groundwork for the affirmation of the episcopate's jurisdictional droit divin, through their preoccupation with the perfecting and governmental power of the episcopal office. Bérulle acted as a strong influence on the thought of SaintCyran, who expanded on the cardinal's views of episcopacy in order to counter the regular threat. Jean-Pierre Camus also used Bérullian concepts of hierarchy and obedience to defend the episcopate from both regulars and the papacy, stressing again and again the elevated position of bishops within the 'true hierarchy' and the absolute authority which they held within dioceses and over their clergy. ${ }^{44}$ His fellow bishops frequently returned to the revitalised notions of hierarchy, authority, leadership and discipline to characterise their position in the church. As Saint-Cyran demonstrated, the notion of episcopal droit divin was a natural bedfellow for these fundamental elements of episcopal identity.

An alert episcopate was not only able to formulate a coherent ideological barrier against both the regulars and the papacy; it was actually able to ensure that its ideology was translated into practical policies that prevented the pope from gaining a foothold in the pastoral discipline of dioceses. Indeed, if the papacy's power over the French bishops is judged by its success in obliging them to submit to its interventions in affairs of pastoral discipline, it is obvious that it completely failed to do so in the seventeenth century. This conclusion is resolutely confirmed by Rome's poor record in its second point of friction with the French episcopate: the trial and judgement of bishops. On this issue, the first instance of conflict occurred in 1625: in his capacity as a papal sub-delegate, Étienne Louytre placed an interdict on René de Rieux, bishop of SaintPol-de-Léon, to punish him for protecting those Carmelites who refused to obey the papal brief appointing Pierre de Bérulle as their superior. ${ }^{45}$ Louytre had actually been appointed by the original papal delegates, Cardinals La 
Rochefoucauld and La Valette, but the episcopate refused to accept that his powers entitled him to judge a bishop. It reacted vigorously to the insult rendered by a priest presuming to punish his hierarchical superior, insisting that it was the task of bishops to discipline priests and not vice versa. ${ }^{46}$ The second case concerning judgement also involved the unfortunate Rieux, although on this occasion there was no representative of the lower clergy involved to incense the bishops even further. Rieux was the kind of bishop to invite trouble, for, along with Alphonse Delbène, he was deprived of his seat by four papal commissioners for treasonous activities in the early 1630s. ${ }^{47}$ Following representations by Rieux and Delbène, the Assemblies of 1645 and 1650 took up their cases, alleging that both bishops had been illegally tried. Shortly afterwards, the 1655 Assembly became involved in defending the archbishop of Sens against Rome's efforts to judge him through papal commissioners when he refused to accept the anti-Jansenist brief Cum occasione without reservations. In the long term, perhaps the most damaging episode involved the four Jansenist bishops who refused to accept the anti-Jansenist Formulary as ordered by the papacy, Assembly and crown during the late 1650s and 1660s. ${ }^{48}$ Once again, the French episcopate complained that papal commissioners were entirely improper judges of episcopal behaviour.

The bishops' stance remained solid throughout the century. At stake, they believed, was the dignity of the episcopal office and the prerogatives which both preserved and enhanced it. Of course, the assumption that bishops formed a special corps in the church and that this status brought certain privileges was not unique to the seventeenth-century French episcopate, but during this period it proved extremely sensitive to its gallican rights. One reason for this was the fact that the papacy appeared particularly willing to challenge or ignore these rights on a number of occasions, an aspect of the growing centralising and monarchical tendencies of post-Tridentine Rome. ${ }^{49}$ But the facts that French bishops were exceptionally watchful for potential slights to their office and were very conscious of their privileges were also responsible for the high incidence of collisions. The bishops' confidence in the stature of their office and in the legitimacy of their claims was actually enhanced when they withstood their opponents; success both encouraged their resistance to subsequent 'attacks' and inflated their attachment to their opinions. Meanwhile, their confidence in their convictions was also fed by the steadily disseminated celebrations of episcopal prestige developed by reformers like Bérulle and Olier.

These bishops did not believe that their status exempted them from punishment when deserved, but they were anxious to ensure that the onerous obligations and high rank of their office were matched by equally solemn and correct procedures of judgement. This point was made forcefully by Bishop Gondrin of Sens in the Assembly of 1645, during the debate over René de 
Rieux's deposition. He observed then that the judgement of bishops related to the honour of God and should be treated particularly gravely, given the eminence of prelates within the church. ${ }^{50}$ However, not content with merely reiterating this claim, the episcopate painstakingly elaborated the necessary steps to ensure that it was implemented in practice. These steps formed the backbone of the bishops' arguments with the papacy throughout the century and were consistently promoted as the ideal; any proposed divergence from them was classed an affront to episcopal dignity.

The touchstone for the episcopate's view of judgement was the fourthcentury Council of Sardica (343 AD), which had originally regulated the manner of judging prelates. The bishops followed its rules faithfully, publicly detailing them in every quarrel to support their position. Sardica stipulated that, in the first instance, bishops were to be judged by their co-provincials. Only then was it possible to appeal to the pope, who, if he recognised suitable grounds, would choose bishops from the neighbouring province to judge the matter once again. Even then, a second appeal was possible, in which case a papal legate would resolve the affair absolutely on the pope's behalf. ${ }^{51}$ Of course, these procedures limited papal jurisdiction in the judgement of bishops considerably, since a bishop vindicated by his confreres could not subsequently be judged by the pope. Significantly, also, in defending a bishop's prerogative to be judged by his provincial confreres in the first instance, the episcopate rejected the Tridentine legislation which attributed the judgement of episcopal causes to the pope. René de Rieux did not make a single reference to it in his complaint to the Assembly in 1625, choosing instead to concentrate on the principles of Sardica. Nor was it mentioned by the episcopate during the Jansenist affair. ${ }^{52}$ Likewise, in 1645, Charles de Montchal and Louis-Henri de Gondrin focused on the earlier Council. When they mentioned Trent, they did so only to claim precedence for the Sardica decrees since, as Gondrin put it, gallican privileges meant that the Tridentine decrees had not been formally received under French law. ${ }^{53}$ The fact that he was a member of an episcopate which continued to fight tooth and nail to discipline regulars on the basis of this alien Council did not appear to bother his conclusion here.

As the century progressed, the episcopate's position grew steadily more entrenched. Simultaneously, it became increasingly vocal in its self-defence, especially so since its initial battle terminated on a rather ambivalent and unhappy note. On hearing René de Rieux's complaint against Louytre in 1625, the episcopate immediately took up his case, and the Assembly issued a strongly worded condemnation of the sub-delegate's conduct. This vociferous opposition to his judgement ensured that it could not be adopted as a harmful precedent in the future. Yet the bishops could not have been pleased with the fact that they were forced to concede, following pressure from Rome, that the Assembly's 
condemnation of Louytre's conduct was merely an opinion and not an act of jurisdiction, even though that condemnation had actually explicitly nullified Louytre's interdicts against the bishop. $\cdot{ }^{54} \mathrm{~A}$ call for a national council by Gabriel Laubespine, bishop of Orléans, to resolve the dispute was not followed through, the episcopate being reluctant to take a step that might lead to schism. Yet the fact that Laubespine was moved to suggest such a step at all indicates the level of episcopal discontent with the entire affair. After all, as Rieux complained, actions like Louytre's, if unchecked, would contribute to 'the ruin of episcopal dignity'. ${ }^{55}$ His words were a constant refrain in the conflicts which followed and explain why the bishops proved so assertive in defence of their office.

The disappointing outcome to this particular altercation in 1625 coincided precisely with the papacy's failure to support the Déclaration sur les réguliers and the widely admired statutes of the Council of Bordeaux. They combined to leave a legacy of suspicion and bitterness between the bishops and Rome for decades. This became acutely apparent in 1645 and 1650 when unresolved incidents involving the trials of rebel bishops arose once more. René de Rieux had been deposed in 1635 for assisting Marie de Medici's flight to Flanders in 1631 as well as for a visit paid to the exiled queen mother soon afterwards. After he pleaded against his deprivation before the Assembly in 1645, it managed to score a resounding success in having the judgement overturned. It also used the publicity to make an emphatic act of protest against the forms adopted by the papacy. In this instance, the bishops really were making the best of their opportunities for, in fact, the papacy had proved quite accommodating to their pressure. Without real resistance, it overturned the decision of the commissioners against Rieux, in consequence of the then cool relations between Cardinal Mazarin and the pro-Spanish Pope Innocent X. ${ }^{56}$ It was the French crown that proved most reluctant to have Rieux's deposition overturned, since it was for his alleged participation in a revolt against the crown that he had been deposed. The episcopate was well aware of this, but it did not waste a chance to complain bitterly about the papacy's failure to follow correct judicial procedures in the case. ${ }^{57}$

Five years later, the bishops scored another resounding success, though this was an incident which involved them in still greater exertions. After being found guilty of complicity in the Montmorency revolt of 1632, Alphonse Dèlbene was deposed from Albi by the same papal commission that had brought Rieux to his knees. In the late 1640s, the disgraced bishop sought repossession of his see on the grounds that since he had not been judged by twelve of his coprovincials, his deposition by the papal commissioners was unlawful. When he died in 1651, his nephews Barthélemy, bishop of Agen, and Alphonse III, bishop of Orléans, pressed his case in the Assembly to ensure that episcopal rights were not injured in future by references to their uncle's fate. ${ }^{58}$ This time, 
however, the Assembly did not have an easy road, for the papacy proved very unwilling to allow the episcopate any further margin of victory. The Assembly acted on several fronts, first enlisting Pierre de Broc of Auxerre to compose a critical letter to Rome urging that future judgements be carried out by the accused's fellow bishops. The letter harked back explicitly to the brief of commission issued by the papacy in the Rieux case, and specifically stated that it could not be treated as a precedent. The Assembly then composed an act of protest to the papal nuncio, Nicolo Bagno, repeating this claim, and sent a circular to all French bishops, requesting that they refuse to act as papal commissioners unless proper procedures were followed. ${ }^{59}$ These actions were officially recorded in the procè-verbal of the Assembly, as a future line of defence. Bagno, however, flatly refused to accept the act of protest, declaring that should the Assembly's representatives try to deliver it to his residence, he would slam the door in their faces. As both he and the Assembly knew, delivery of the act was essential if it was to have any effect. The Assembly was forced to resort to subterfuge to ensure that it made its intended impact: two notaries were sent to Bagno's residence early one morning and they handed the protestation to the porter on duty. ${ }^{60}$

Its triumphs in 1645 and 1650 left the episcopate with official points of reference for the future, and they were subsequently drawn upon to defend those bishops whom the papacy wished to judge by commission during the 1650s and 1660s. ${ }^{61}$ During the Formulary conflict, the accused bishops themselves, under threat of a papal brief ordering commissioners to judge them, argued persistently for trial by their co-provincials, and were supported by their fellow prelates, ${ }^{62}$ even when these were far from enthusiastic about the Jansenist doctrines of grace and salvation: 'The interest of our confreres [is] that of the episcopate . . . nothing could be more dangerous than to allow the introduction of a new way to proceed against the bishops of France, which might render them culpable without accusation and have them condemned without any form of judgement. ${ }^{63}$ The first hint that Jansenism would unleash the longest-running clash between the bishops and Rome over episcopal trial and judgement came when Gondrin of Sens refused to publish the papal bull Cum occasione (1653) unless he could add a pastoral letter denying that the narrowly Augustinian doctrine of Cornelius Jansen's Augustinus was heretical. ${ }^{64}$ Four years before, more than eighty French bishops had presented five Jansenist propositions culled from the notorious treatise to the pope, and had requested that he pronounce upon their orthodoxy. When Innocent X issued a bull condemning the propositions, it was endorsed by an unofficial assembly of thirty prelates, convened by Mazarin in $1653 .{ }^{65}$ After Gondrin rejected the bull's terms, the papacy suggested that he should be judged by a commission of delegates, chosen by the pope. Predictably, given their previous behaviour on this issue, his fellow 
bishops vociferously opposed the proposal and managed to stall the process until the archbishop could be persuaded to submit unconditionally to the bull's terms in $1655 .{ }^{66}$ An outright confrontation was temporarily averted, and the episcopate was left in its defensive position, but with its principles intact.

This clash, however, was just a sign of what was to come. Almost as soon as this quarrel had been resolved, the plight of the Jansenist bishops moved to the centre of the stage, presenting the episcopate with its greatest challenge, but simultaneously offering it the perfect context to continue to present and fight for its opinions. In September 1654, Innocent X issued a second brief to rectify the deficiencies of Cum occasione. This explicitly stated that the condemned propositions were indeed 'contained in Jansen's book entitled Jansenius', although it was issued only after the French episcopate had actually made that claim. ${ }^{67}$ It was followed by yet another constitution in 1656, in which the new pope, Alexander VII, confirmed his predecessor's decision and enjoined prelates to ensure that it was obeyed.$^{68}$ In March 1657, the Assembly gave its considerable weight to the campaign, by inviting all those bishops resident in Paris to a session which received Alexander's constitution. The Assembly added to it an anti-Jansenist Formulary requiring universal subscription. ${ }^{69}$

Almost immediately, four bishops (Pavillon of Alet, Arnauld of Angers, Choart de Buzenval of Beauvais and Caulet of Pamiers) refused to issue the Formulary without reservations which contradicted it. ${ }^{70}$ In April 1667, an exasperated Alexander VII made known his intention of judging them by a papally appointed commission of nine bishops. He published two briefs, endorsed four months later by his successor Clement IX, delegating two archbishops and seven bishops to judge the recalcitrant four. But the delegated bishops proved conspicuously reluctant to respond to the task, and at least four of the nine expressly refused the commission. ${ }^{71}$ The Jansenist bishops joined forces with them in reiterating the argument presented by the episcopate throughout the century, founding their claim on the Council of Sardica and comparing their predicament to those of 1633 and 1645: the bishops should 'be judged in the first instance by twelve of their confreres only, not chosen by those who would wish to condemn them; but taken from their provinces, and presided by their Metropolitan' ${ }^{72}$ In this heightened atmosphere, Alexander VII was succeeded by the more moderate Clement IX in mid-1667. This facilitated the negotiations that resulted in the 1669 Paix de l'église, which allowed the four bishops to issue the Formulary accompanied by a procès-verbal distinguishing between fait and droit: ${ }^{73}$ an episcopal victory since the dreaded commission never proceeded. ${ }^{74}$ The episcopate's intransigent opposition to even the suggestion of a commission was a significant cause of its abandonment, and the forging of a settlement, for both the papacy and the government were forced to realise just how odious the bishops found the idea. ${ }^{75}$ 
The episcopate's sustained resistance throughout the century to 'illegitimate' and 'unprecedented' modes of judgement illustrated not just the depth of feeling they engendered within it but also the bishops' determination to prevent their creeping incursion into the French church. With the exception of 1625 , the bishops swept the boards in asserting what they believed to be their privileged rights, for although the papacy repeatedly attempted to adopt methods that ran contrary to them, it was largely unable to do so because of the bishops' loud and united objections. Even when Rome managed to judge five prelates on its terms in 1633, its actions backfired in spectacular style, resulting in a definite and official statement of the episcopate's stance and a strongly worded condemnation of the papacy's behaviour. There are close parallels between the bishops' sentiments on trial and judgement and those that shaped their attitude in their quarrels with the religious orders. Those bishops who defended the Jansenist prelates agreed that their preferred means of judgement prevented bishops from being treated as simple vicars of the pope, mere executors of papal judgements, dependent on the pope's will and punishable by him if they disobeyed it. ${ }^{76}$ This was precisely the reasoning that sustained the episcopate's campaign to control the use of papal privileges in dioceses. Fundamentally, it was a vision of episcopal jurisdiction that depended on the notion of droit divin for its validity. Here again, the episcopate's convictions transferred neatly across disputes, for the conflict over the Formulary did not just raise, once more, the troublesome questions surrounding the judgement of bishops. More broadly, it forced the episcopate to define the relative jurisdictional rights of the upper members of the ecclesiastical hierarchy. This obviously included the relationship between the bishops and the pope, but the quarrel also brought to light a jurisdictional dilemma that threatened to fragment the unity of the episcopate itself.

The doctrine of jurisdictional droit divin worked admirably to protect the Jansenist bishops against papal interference in their diocesan government, for the pope could intervene only if they rejected canonical norms and defined articles of faiths. But if the pope could not control the bishops' actions, then who could? To this query, the Jansenist bishops quickly responded that they were answerable only to God. Others, however, devised an alternative answer which obliged individual bishops to obey the collective will of the episcopate. This requirement functioned perfectly if all bishops shared the same views, as they did on the steps taken against the regulars and lower clergy. But it was altogether more awkward if bishops held different opinions on a particular problem like the anti-Jansenist Formulary. In this instance, the jurisdictional droit divin of individuals was pitted not only against papal aggression, but against the corporal droit divin of all bishops. It was not, therefore, just papal 
interference in the government of bishops that was so inflammatory; equally, it was that of the Assemblies of Clergy which claimed to speak for all the bishops.

The refusal to accept the papal bulls and the Assembly's Formulary was a momentous decision by the four Jansenist bishops, and a landmark in their episcopal careers. It precipitated a quarrel which dominated their lives and convulsed the French church for over a decade. In the eyes of their opponents, these bishops were now tainted with the same heresy as the nuns of Port-Royal and the solitaires who refused to demonstrate their rejection of Jansenist doctrines by signing the Formulary without distinguishing between droit and fait. For Pavillon, Caulet, Arnauld and Choart, the actual theological details and arguments of the debate were of less import than their practical effects on their ministries and the church. They all inclined towards the predestinarian, Augustinian theology officially defined in the five propositions, and were consequently very sympathetic to the plight of the Port-Royal solitaires and nuns. However, their personal soteriological beliefs were accompanied by a keen sense of their episcopal duty and rights, and this motivated them just as powerfully.

Of these recalcitrant bishops only Arnauld and Choart had opposed Cum occasione in $1653 .{ }^{77}$ When Caulet and Pavillon entered the fray in 1657, their initial complaint was not merely, and not even primarily, against the condemnation of Jansenism itself therefore, but against what they considered to be the highhanded and unlawful tactics of the Assembly. All four absolutely refused to accept that the Assembly held jurisdiction over bishops and that they were consequently bound to accept its decisions. When Pavillon explained his stance to Vialart, the bishop of Châlons-sur-Marne, he wrote that 'The Bishops do not have to sign or make others sign in virtue of the so-called decree and deliberation of this Assembly', since that body was not a national council and therefore did not possess the authority to enforce signature. ${ }^{78}$ Henri Arnauld expressed the same sentiment: 'The enterprise of the Assembly . . . which wanted to attribute to itself the authority of a national Council, and the power to impose law and penalties on all the bishops . . . is a sufficient reason for a bishop who loves his character not to consent to a usurpation so prejudicial to his dignity. ${ }^{79}$ The bishops were also able to add that the sense of the condemnation was not even sufficiently clear: as bishops, therefore, they were responsible for elucidating it through pastoral letters. ${ }^{80}$ According to this train of thought, doubt remained about the exact sense of the papal condemnation and it was the role of a bishop, as the enlightener of the faithful, to clarify this before offering the Formulary to his clergy. It was not sufficient for the Assembly to require subscription; rather each prelate must act as a source of guidance for his charges. ${ }^{81}$ The question was, therefore, not just a jurisdictional one. It also concerned the pastoral role of bishops over those in their care. Bishops were bound to obey only 
established ecclesiastical and doctrinal laws, and no Assembly could prevent bishops from discharging their duty of enlightenment on a doctrinal question that was open to interpretation by distinguishing between droit and fait.

To make matters more complicated, the Jansenist bishops were not the only prelates to hold this view of the Assembly's authority. Not only did a number of other bishops distinguish between droit and fait in pastoral letters and procès-verbaux when a further papal bull, Regiminis, ordered subscription to the Formulary in $1665,{ }^{82}$ but nineteen prelates, who had themselves accepted the Formulary without adding mandements, defended the actions of the four bishops in letters to Clement IX and Louis XIV in 1667. The Jansenist bishops acquitted perfectly the work of their episcopal charge in distinguishing fait and droit, they argued, and were 'ornaments' of the episcopate in their care of souls. ${ }^{83}$ Before he died, Alain de Solminihac had advised Pavillon upon the authority of the Assembly, in a series of enquiries concerning episcopal government that the bishop of Alet had put to him during the 1650s. When Pavillon enquired about the obedience that bishops owed to the Assembly, Solminihac replied that 'It is good to observe them as much as possible, except in those instances where some notable inconvenience would occur in particular dioceses, ${ }^{84}$ but he did not recommend absolute obedience to the Assembly's decisions.

Nor did Pavillon's other supporters. Godeau of Vence proved to be one of the quartet's staunchest champions, issuing his own explanatory pastoral letter with the Formulary in 1665, and publicly reproving the Assembly's actions. Bishops were obliged, he observed, 'to speak the truth', and the Assembly could not claim the powers of a national council to prevent them fulfilling this responsibility. ${ }^{85}$ Godeau also approved the sentiments expressed by Henri Arnauld in the letters which the bishop of Angers wrote to the king to defend his position, describing them as 'truly episcopal' ${ }^{86}$ Arnauld himself accused the Assembly of injuring the dignity of all bishops through its illegitimate presumption of jurisdiction over them, since 'Each bishop has the power to regulate things in his diocese according to the light that God gives him, in order one day to render him count of his administration.' When, in 1661, the Assembly prohibited bishops who refused to co-operate with its policies from sitting in either provincial or national assemblies, he stormed that 'threats of penalties' had no place in its remit for it was not a national council with jurisdiction over the diocesan government of prelates. ${ }^{87}$

In stark contrast, the Assembly held quite a different conception of both its role and its relationship with bishops. In the 1657 articles, the episcopate had just explicitly declared its support for the theory of episcopal droit divin. Those articles were designed to define the bishops' jurisdictional links with the pope and the lower clergy. When it came to the operation of jurisdictional rights within the episcopate, however, the Assembly's prelates displayed a 
radically different attitude. In effect, the Assembly attempted to impose its own jurisdiction on all French bishops; when it did, it was branded a despot. Of course, the Jansenists' personal doctrinal leanings played a role in this, as they were reluctant to assist efforts to condemn the Augustinus, a work that they considered to be perfectly orthodox. Yet even bishops who were rigorists rather than Jansenists, such as Godeau and Gilbert de Choiseul, sympathised with their arguments. The prolonged quarrel kept the intricacies of episcopal jurisdiction firmly in the public arena, forcing those prelates who endorsed the Assembly's policy towards the four bishops to reflect upon and to reconcile its inherent contradiction.

The Assembly claimed competence to impose its spiritual competence on individual bishops and to punish those who disobeyed its commands. How did it defend this assertion? As Antoine Arnauld noted in 1661, the Assembly had not previously claimed these powers and had not presented itself as a national council with authority over all bishops. Instead, it had merely offered its advice on spiritual matters to bishops 'through instruction and friendship', and had imposed its will only in temporal affairs. ${ }^{88}$ Now, however, its critics accused it of setting an unlawful precedent by assuming the mantle of a national council. They found ample ammunition in the fact that the Assembly's prelates did actually claim that its decrees were those of a national council, and binding on all bishops and within all dioceses. Pierre de Marca was among those who argued that the Assembly's bishops were chosen in provincial assemblies, so that they represented the French episcopate and acted in its name: 'All the authority of the gallican church, as far as doctrine and the rule of ecclesiastical discipline are concerned, resides in this general assembly, which is . . a national council. ${ }^{199}$ In a letter to the king, the deputies agreed that the entire episcopate, was 'found in effect' in the Assembly of Clergy and was 'represented by the procurations of the absentees.' Individual bishops had to accept the doctrinal and disciplinary decisions of the national council in which they participated personally or by proxy. ${ }^{90}$ This was a major departure within French episcopal thought; certainly, a century before, those French bishops who travelled to Trent had not believed that a national council could judge matters of faith. ${ }^{91}$ It was not that the Assembly now denied the power of individual bishops to judge spiritual matters. In fact, the episcopal deputies considered this to be an intrinsic element of the office of bishop. This was exactly what they conceived themselves to do in Assembly when they accepted the papal constitutions against Jansenism: these were rendered irreformable and binding once they had added their approval to them. ${ }^{92}$ Yet not only did the deputies reject papal infallibility in one fell swoop; they also had to reconcile their behaviour with the notion of bishops' jurisdictional droit divin. They managed to do so by appealing to their representative authority as members of a national council, who acted in the 
conviction that the jurisdiction of individual bishops could be superseded when they refused to accept the judgements of the episcopate as a unity.

It was unprecedented for the Assembly to assume the mantle of a national council as it did during the late 1650 s and 1660s. Although it had always presumed to speak on behalf of the French church and the episcopate, it had never before so forthrightly acted upon a doctrinal matter and demanded the unqualified obedience of all the bishops. Nor had it assumed before the right to impinge upon the jurisdiction of particular bishops who refused to accept its spiritual judgements. Bishops were now no longer simply requested to follow the strategies and guidelines developed by their confreres in Assembly; instead, they were commanded to do so. The immediate reason for this was the perceived urgency of the Jansenist issue and the acute need to resolve it as quickly and as thoroughly as possible to preserve the doctrinal homogeneity of the French church. If it was to have any hope of rooting out Jansenism from every parish in the realm, the Assembly had to claim unflinching authority over bishops in judgements of doctrine and in diocesan jurisdiction. Of course, it was not easy to achieve that, and Jansenist doctrines would continue to find support for decades to come. ${ }^{93}$ Yet the legacy of the principles articulated by the Assembly in the Formulary dispute would enable a later generation of prelates to tackle that resilience: in the eighteenth century, an assembly of bishops approved another anti-Jansenist papal bull, Unigenitus, and presented its decision as binding upon all bishops and the entire French church. ${ }^{94}$

In the short term, the Assembly failed in its task, for it did not manage to cow the four Jansenist bishops into submission. Yet the dispute set two portentous precedents: first, future Assemblies could argue that their judgement of spiritual issues was both legitimate and absolutely effective over all bishops and the French church; second, for a doctrine to become an official tenet of that church, it had to be confirmed by the episcopate and not just by the pope. From this perspective, it is hardly surprising that in 1682 the episcopate endorsed the Gallican Articles enunciated by the bishop of Meaux, Jacques Benigne Bossuet. ${ }^{95}$ Although to proclaim their doctrines officially was inflammatory, three of the articles actually codified the principles underpinning episcopal actions for most of the century, and their publication was the culmination of decades of tensions and quarrels between the bishops and the papacy.

The events of this extraordinary assembly have been fully documented elsewhere, ${ }^{96}$ but it is appropriate here to examine the relevant articles individually, pinpointing the connections between the doctrines that they espoused and the views that had, by this time, become standard elements of the episcopate's ideology. ${ }^{97}$ Citing the decrees of Constance, article 2 affirmed that the decisions of a church council held precedence over those of a pope; the third article developed this point further, proclaiming that papal power was subject 
to established church laws and customs, including 'the rules, customs and institutions accepted in the French kingdom and church'; finally, article 4 qualified papal power yet again by confirming that the pope's decisions in matters of faith were not irreformable 'without the consent of the entire church'. ${ }^{98}$

Bossuet later commented, in 1700, that it was 'a hugely important coup to raise the ancient doctrine of France by the authority of the bishops' ${ }^{99}$ This was certainly an accurate observation: the Gallican Articles, officially promulgated by an assembly of fifty-two bishops, provided a coherent and inclusive benchmark for relations between Rome and the French church. But the episcopate could certainly draw on its previous expressions of these views to guide it in 1682. These were entirely consistent with the four articles: the bishops had consistently fought any effort by the papacy to override customary episcopal privileges in the cases of Rieux, Delbène, Retz and the Jansenist prelates; equally, they had always claimed to defend established 'rules and customs' when fighting the independence of regulars within dioceses, and had repeatedly endorsed the theory of episcopal droit divin which rendered papal intervention in dioceses illegitimate without episcopal consent. Feud after feud with the regulars and the papacy served to swell the bishops' resentment towards what they perceived as Rome's unwarranted efforts to increase its hegemony at the expense of episcopal jurisdictional rights and dignity. Simultaneously, the episcopate's increasing confidence also led it to desire a fuller role in the government of the church. During the 1650s, the episcopate had assumed a leading deliberative role in judgements of faith on the basis that the bishops in assembly were entitled to approve the papal constitutions against Jansenism. This was intrinsically related to the episcopate's rejection of papal infallibility, since it was the Assembly's endorsement of the constitutions that was deemed to render them irreformable. There is an obvious co-relation between the national council of bishops which met in 1682 and the Assemblies of 1655 and 1665. The Jansenist bishops had hotly denied that these earlier Assemblies were national councils which could claim to be representative of the entire episcopate, but once the idea was introduced, it was a short step towards a 'national council' that would pronounce on papal infallibility and conciliarism. ${ }^{100}$

In fact, although the 1682 articles marked the first occasion during the seventeenth century when the episcopate expressly embraced conciliarist theory, the prevailing view of bishops as hierarchical governors, judges of faith and leaders of the faithful was perfectly attuned to this concept of institutional government. The Assembly's growing willingness to capture the functions of a national council indicated that the bishops believed they should play a major deliberative role in church government, so that they were not simply agents or delegates of the pope. Naturally, the Jansenist bishops were particularly enthusiastic about this form of ecclesiastical government. When they found themselves 
at loggerheads with the papacy over the right and obligation of bishops to act as judges of faith and enlighteners of the clergy, it was helpful to claim that, ultimately, only a church council could resolve a previously undefined question of faith. ${ }^{101}$ Yet conciliarism also received support from many other bishops, such as Godeau, Choiseul, Gondrin, Marca and Bossuet, all of whom denied papal infallibility in matters of faith and proved increasingly keen to share in the judgement of spiritual questions. ${ }^{102}$ As Rome, therefore, progressed towards a more autocratic conception of the church and of papal authority, the bishops of France moved steadily towards an episcopate-centred and conciliarist view of the church, founded on the dynamic primacy of the episcopal corps within this institution and on bishops' unique and divinely granted powers of jurisdiction and order.

In the past, the episcopate has been accused of failing to appreciate the 'osmosis' existing between the universal church and particular churches. ${ }^{103}$ This criticism assumes that the bishops' position was posited on the absolute independence of each local church within the universal and, therefore, fails to acknowledge the subtleties of their opinions. They were fully aware that the particular churches which they governed were part of a wider ecclesiastical structure that was composed of local or diocesan churches, each connected through shared traditions, faith and discipline. They certainly did not desire the complete independence of particular churches: rather, collaboration among bishops, the pope and regulars was a benefit, even a necessity, for the church. It was this realisation that drove so many bishops to attempt to mend the damaged relations between Rome and the episcopate during the crises which threatened to drive them permanently apart. So we find the archbishop of Sens and the bishops of Châlons-sur-Marne, Comminges and Meaux desperately seeking common ground between the Jansenist bishops and Rome during the $1660 \mathrm{~s}$ in order to arrest the deterioration in relations between the episcopate and the papacy. ${ }^{104}$ But this appreciation of the value of co-operation was tempered by the belief that the papacy had to respect and support episcopal jurisdiction in order to ensure that ecclesiastical discipline and order were preserved. Collaboration was indispensable provided that the ruling rights of bishops were not breached by papal authoritarianism.

The bishops' relations with successive papal nuncios testified to the weight that they ascribed to the connections between Rome and the French church. For the parlements, the papal nuncio was no more than the ambassador of a foreign prince, without any power of action in France. ${ }^{105}$ In contrast, even though Silingardi might believe that he and his fellow nuncios were merely spectators of the great 'misfortunes of the apostolic seat' in France, ${ }^{106}$ the episcopate clearly considered them to be far more than ordinary diplomatic representatives: they 
were papal delegates with particular spiritual powers over visitation, punishment and absolution. The bishops hesitated to abandon contact with them as a result and, even when in absolute disagreement with Rome, always attempted to follow established procedures to convey their opinions to the pope through his official representative. The very fact that they scrupulously did so confirms the value that they placed on traditional ecclesiastical structures and on the ageold connections between popes and bishops. Although, therefore, the episcopate might obey a royal command to cease all visits to Nuncio Scotti in $1639,{ }^{107}$ it would go to extraordinary lengths to ensure that due procedures were followed to the letter when communicating its views to the pope through his nuncio. On at least two occasions, it was forced to thrust protestations into the hands of the nuncio's porter, after the nuncio, in foiled attempts to obstruct their delivery, had refused to accept them. ${ }^{108}$

Of course, the bishops tended to view ecclesiastical government from their own perspective, like the regulars, the curés and the popes. Their ideals and behaviour were generally characterised by a pronounced sense of corporal unity: time and time again, the bishops united to protect their shared identity and rights. Only the Jansenist bishops, however, managed to expand this fraternity into a concern for the well-being of the entire church. All four have been accused of an extreme hiérarchisme in their work as prelates and even of a separatist tendency in their understanding of the episcopate's relationship with the papacy. ${ }^{109}$ Both of these rather disingenuous claims need to be qualified: in the first place, a hierarchical conception of authority was a pronounced feature of the diocesan government of all French prelates who undertook diocesan administration with any degree of conscientiousness during the seventeenth century. Jansenist bishops were not necessarily any more autocratic in their government than non-Jansenists. Furthermore, to distinguish Jansenist bishops from other members of the French episcopate by their 'separatist tendencies' assumes that that they actively or passively supported the separation of the French church from the papacy. That is simply a perpetuation of seventeenthcentury propaganda. ${ }^{110}$ Non-Jansenist and Jansenist bishops shared the conviction that a spirit of mutual respect should characterise the relationship between the pope and prelates, a fact that explains the backing for the Jansenists from non-Jansenist bishops in their struggle with the papacy. All desired a large degree of autonomy in their diocesan activities. Obedience to the papal will was possible when Rome did not overstep its jurisdictional limits, although, of course, the bishops estimated that it did this with regularity. Yet not even the most convinced Jansenist bishop ever voiced support for complete partition of the two powers or of the French church from Rome. In fact, two of them actually allied with the pope to resist the crown's extension of the régale during the 1670s. ${ }^{111}$ 
The bishops' favoured style of government was collegial, involving monarchical authority in dioceses, but a more democratic or conciliar form of government in the church as a whole. Their collegium encompassed all prelates and included the pope, bishop of Rome. As Camus explained it, the pope was 'bishop of the universal church' but not the 'universal bishop', which meant that he was first among bishops; in Cyprianic terms, he was the centre of unity for the episcopate and for the church, but he did not govern particular churches outside Rome, his own see. Bossuet was certainly not the first bishop, only the most famous one, to believe that the episcopate was possessed by the Apostles' successors in solidarity, in a spirit of 'union and unity of subordination' which granted Peter's successor pre-eminence, though not absolute authority of jurisdiction or judgement. ${ }^{112}$ For this reason, the bishops vehemently endorsed their jurisdictional independence in their dioceses, but also sought prominence in the judgement of prelates and spiritual questions. Conciliarism was a logical progression from this viewpoint since it offered bishops the means to exercise their collective authority.

The development of such categorical convictions within the French episcopate was largely due to an intense sense of self-identity, based on the concepts of governing, judging and perfecting, as well as to revitalised gallican traditions. Closely related to these was the sense of mutual responsibility that characterised the attitudes and actions of bishops through this period. Infringements on their rights and attacks on their office encouraged a defensive outlook, drawing them closer together and highlighting the bonds linking these elite descendants of the first apostolic community of bishops. The episcopate frequently acted in concert on questions concerning discipline, faith and bishops' rights, and individual prelates persistently drew attention to their links with other members of the episcopate. Those seeking the aid of their fellows usually resorted to appeals to their common character: Mathieu Bourlon, Alain de Solminihac and Antoine Godeau declared that assaults on particular bishops were an affront to all. They had to be checked since submission in one conflict would inevitably lead to even greater difficulties for other bishops. ${ }^{113}$ René de Rieux consciously drew on the corporate aspect of episcopacy when he appealed to the Assembly in 1625 for its support against Étienne Louytre. The sub-delegate's actions wrought 'upheaval of the ecclesiastical hierarchy, and an 'extreme scorn of the dignity, power and authority' of all the bishops. ${ }^{114} \mathrm{His}$ appeal to his brethren's sense of collegial solidarity succeeded and was, in fact, adopted by the Assembly itself when it sent letters to all French bishops explaining its declaration against Louytre and soliciting their support. ${ }^{115}$ But episcopal unity was not always simply a matter of communion among French bishops. It incorporated the well-being of all bishops who belonged to the episcopal corps of the ecclesiastical hierarchy. 
On the other hand, the conflicts that distanced the episcopate from successive popes were often narrowly and exclusively centred on questions of jurisdiction, with emphasis on, and continual repetition of, ecclesiastical customs and laws. Detrimentally, the bishops' attention was directed away from the apostolic and pastoral angles of the disputes. These were pushed into the background while episcopal dignity and jurisdictional power seemed to become ends in themselves, instead of the means to foster the spiritual welfare of the faithful. The Jansenist bishops shared this tendency to some extent, but they managed to prioritise not just episcopal communion and rights, but the apostolic unity of the universal church and the responsibility of prelates to protect this entire community. They too appealed for support from other bishops on the basis of their membership of a unique hierarchical corpus, and highlighted the repercussions for their shared office if bishops were not allowed to act as governors and judges and if their dignity was injured by inappropriate juridical procedures. In their 1668 letter to their fellow bishops, they portrayed their personal situation as 'the last degradation of common dignity', and starkly warned that if they were judged by commissioners then the future was wide open for further attacks on episcopal rights. Prelates were, this quartet insisted, brothers of the pope, and members of the same episcopal college. They should therefore be treated with the respect due to that status. ${ }^{116}$

A striking difference, however, between the Jansenists' arguments and those of bishops such as Rieux and Montchal was their frequent allusions to the health of the whole church. According to Pavillon, his sole motivation in the Formulary dispute was to acquit his obligation 'to govern, serve and help' the Holy Spirit's church. ${ }^{117}$ Other bishops dwelled on the implications of jurisdictional and judicial questions for the episcopate, but did not broaden their argument to encompass their effect on the universal church. Of course, an implicit element of their argument was the belief that papal injuries to episcopal privileges and dignity would indirectly harm the spiritual and moral welfare of the faithful throughout the church. The Jansenists, on the other hand, frequently claimed that they were established by Jesus Christ 'to govern . . . as his vicars . . . the portion that is due to us, and to respond at different times to the needs of the universal church'. ${ }^{118}$ As Cyprian had argued, 'There is only one episcopate, of which each bishop possesses an interest in solidarity . . . the church was committed by Jesus Christ to all the episcopal college . . . each bishop is not so confined to his own flock that he is not called upon to watch . . over the entire flock of Jesus Christ which comprise all the faithful. ${ }^{119}$ Consequently, Henri Arnauld could not abandon the functions of his episcopal charge, which bound him to act as 'the eyes and mouth of the church.' ${ }^{120}$

For these prelates, the question of jurisdiction did not overtake those of pastoral responsibility and the apostolic vocation to become a goal in itself. 
Pavillon was able to defend his intransigence by referring to his role as 'the depository, like my confreres, of the faith and discipline of the church, and [I am] obliged to support and defend it, on occasions where I have reason to believe that it is wounded. ${ }^{121}$ Antoine Arnauld later expounded this vision of episcopacy, writing to Pavillon that bishops must concern themselves with the well-being of the entire church by 'opinions, counsels and remonstrances'. ${ }^{122}$ In upholding their jurisdictional rights, these bishops persistently interwove them with the pastoral care and needs of all the faithful, a linkage that many other French bishops tended to overlook in their conflicts with the popes. The Jansenist bishops felt morally obliged to undertake an apostolic and episcopal crusade on behalf of the entire church. Of course, this attitude fitted comfortably into the general tendency of all Jansenists to see themselves as beleaguered advocates of truth within the church, who suffered heroically that others might benefit. ${ }^{123}$ But it certainly had acute and profound resonance when applied to the character of the episcopal office, and subsequently to the specific experiences of these four high-profile bishops.

In relation to episcopal-papal relations, therefore, the collegial conception of episcopacy attained its most complete expression in the outlook and conduct of the Jansenist bishops. Generally, however, the episcopate argued for a deliberative voice in church decisions on matters of discipline and faith, ascribed a central place to bishops within the church structure and increasingly permitted the Assembly to be its definitive voice. Its construction of episcopal and papal power sought the best of all possible worlds by proposing an ecclesiology that simultaneously accommodated collaboration and jurisdictional autonomy. This was a difficult balance to achieve, and the bishops were pushed towards it by their growing fear that if they did not, then they would become nothing more than a collection of servile papal puppets. Their convictions were supported and encouraged by the vibrant reform currents of contemporary France, which highlighted the dignity of their hierarchical station and the essential authoritative role which they should play within dioceses. In the Formulary affair, all of these factors coalesced to produce a jurisdictional crisis that would reverberate in the episcopate's actions for many decades to come. Therefore, of all the jurisdictional struggles which preoccupied the bishops, it perhaps most strikingly demonstrated the principles which underlay their behaviour towards the regulars, the papacy and the curés through the seventeenth century.

Notes

1 Nuncio Bichi, quoted in Chesneau, Paris, i, p. 11; Gasparo Silingardi, Correspondance du nonce en France. Gasparo Silingardi érêque de Modène (1599-1601), ed. Bertrand Haan (Rome 2002), p. 418, Nuncio Silingardi to Aldobrandini, 2 April 1600.

2 Camus, Considérations, p. 151 ; Camus, Unite, pp. 94, 147.

3 Antoine Godeau, Histoire de l'église, 6 vols (Paris 1653), iv, p. 527.

4 Several commentators have suggested this. See John Bossy's remarks in Evennett, Spirit, p. 136. 
5 J. Salmon, Renaissance and Revolt. Essays in the Intellectual and Social History of Early Modern France (Cambridge 1987), pp. 155-88; J. Salmon, 'Clovis and Constantine. The Uses of History in Sixteenth-Century Gallicanism', JEH, 41 (1990), 523-605.

6 Isaac Habert, De l'union de l'église avec l'éstat (Paris 1641).

7 Bossuet, Oeuvres oratoires de Bossuet, ed. J. Lebarq, 7 vols (Paris 1890-97), vi, pp. 103-5, 134; Jacques-Benigne Bossuet, Oeuvres completes de Bossuet, ed. F. Lachat, 31 vols (Paris 1865-66), xvii, p. 585. The most detailed exposition of Bossuet's gallicanism is found in Martimort, Bossuet, but see also Richard Costigan, 'Bossuet and the Consensus of the Church', Theological Studies, 56 (1995), 652-72.

8 The provincial statutes of Mathias Hovius, bishop of Mechelen, received the same treatment in 1607. He was forced to submit to Rome's revisions: Craig Harline and Eddy Put, $A$ Bishop's Tale. Mathias Hovius among his Flock in Seventeenth-Century Flanders (New Haven and London 2000), pp. 125-7.

9 Paolo Prodi, 'Charles Borromée, archevêque de Milan, et la papauté', Revue d'Histoire Ecclésiastique, 62 (1967), 379-411.

10 Archbishop Villars of Vienne termed the council 'a witness of your [Sourdis's] prudence and happy conduct where the Holy Spirit presided'. The statutes are contained, with relevant correspondence, in 'Documents divers relatifs au concile provincial de Bordeaux', ed. Ducaunnes-Duval, Archives Historiques du Département de la Gironde, 17 (1877), 377-500.

11 A supportive pamphlet was also published, but I have been unable to identify Sourdis as its direct instigator: Remarques sur quelques decrets du concile provincial de Bourdeaux, tenu pas monseigneur l'illustrissime cardinal de Sourdis, au mois d'octobre 1624. Touchant les messes parochiales, les confessions à son propre curé à la feste de Pasques: et les exemptions des religieux (Paris 1625).

12 'Documents', ed. Ducaunnes-Duval, 379-480.

13 Ibid., 470-1.

14 Paul Gouyon, L'Introduction de la réforme disciplinaire du Concile de Trente dans le diocèse de Bordeaux (1582-1624) (Bordeaux 1945), p. 223.

15 Chesneau, Paris, i, p. 175.

16 BN, Ms. Fr. 3677, fo. 175, letter of Béthune (ambassador) to Phelypeaux (secretary of state), 5 December 1625.

17 AN, G8* 648a, 20 November.

18 'Documents', ed. Ducaunnes-Duval, 379.

19 Bossuet, Oeuvres completes, xxii, pp. 781-2.

20 Bonnot, Arnauld, pp. 252-68; Dubruel, 'Hiérarchie' (1920), 86.

21 Golden, Rebellion, p. 23; Hermant, Mémoires, i, p. 665.

22 Beore this, Retz's chosen vicar-general, Jean-Baptiste Chassebras, had administered the diocese despite government opposition: Golden, Rebellion, p. 48.

23 Blet, Clergé ... monarchie, ii, p. 144; Golden, Rebellion. p. 53.

24 AN, G8*653, 29 November.

25 Blet, Clergé ... monarchie, ii, p. 246.

26 Solminihac, Lettres, ed. Sol, p. 621, Solminihac to de Paul, 3 May 1659.

27 Eugène Sol, Le Vénérable Alain de Solminihac abbé de Chancelade et érêque de Cahors (Cahors 1928), pp. 166-73.

28 Jean-Marie Vidal, Henri de Sponde, recteur de Saint-Louis des Français, érêque de Pamiers (1568-1643) (Rome 1929), pp. 177-8.

29 Cinq visites, ed. Contrasty, pp. 119-22: 'Sous un vêtement si humble se cache un tel orgueil. Ils mettent toujours en avant leurs privilèges apostoliques ... le droit de donner la communion pascale qui seul semblait rester aux pauvres curés, n'est plus à l'abri de leur usurpation.'

30 Ibid., p. 154.

31 Recueil des actes, i, cols 687-8: 'Les Évêques successeurs des Apôtres sont établis de Jésus Christ dans son Église ... ils reçoivent immédiatement de lui leur juridiction pour le régime et gouvernement spirituel de leurs Églises, dont ils sont les chefs de droit divin avec 
subordination à Notre Saint Père le Pape . . . ils sont les pères, pasteurs et docteurs de tous les fidèles qui sont dans leurs diocèses.'

32 AN, G8* 653, 27 March.

33 Jean-Pierre Camus, L'Esprit du bien-heureux François de Sales, évesque de Genève, 3 vols (Paris 1840), i, pp. 155-6. This was first published in 1639.

34 Camus, Unite, p. 127.

35 Blet, Clergé ... monarchie, ii, pp. 247-9.

36 AN, G8*655b. The final declaration is printed in Hermant, Mémoires, iii, pp. 277-9.

37 AN, G8*659a, fo. 26r-v: '. . . de droit divin le pouvoir de donner les permissions à ceux des prêtres qu'ils choississent pour les aider en ces saints ministères, de prêcher, de confesser, et d'absoudre, comme aussi de révoquer cette permission quand ils le trouvent à propos'.

38 Ch. 3, p. 101

39 Blet, Assemblées, p. 40.

40 A. D. Wright, Catholicism and Spanish Society under the Reign of Philip II, 1555-1598, and Philip III, 1598-1621 (Lewiston, Queenston, Ontario and Lampeter 1991), pp. 151-2.

41 BN, Ms. Fr. ii 635, fos 155-66.

42 Blet, Assemblées, pp. 46-65.

43 Ch. 3, p. 101.

44 Camus, Unite, pp. 88-119; Camus, Considérations, p. 64.

45 Blet, Clergé . . monarchie, i, pp. 296-9.

46 Procès-verbaux, ii, pp. 53-5. Rieux complained that 'a simple priest, who is subject to all messieurs the bishops' had attempted to accuse and punish his hierarchical superior as well as infringe upon his jurisdictional rights by acting in his diocese without his permission.

47 The list of suspects also included Jean Plantavit (bishop of Lodève), Paul-Antoine FayPeyraud (bishop of Uzès) and Pierre de Fleyres (bishop of Saint-Pons). The case against Plantavit was dismissed, and both Fay-Peyraud and Fleyres died during their trials.

48 The literature on Jansenism is voluminous and wide-ranging in its themes. The indispensable introduction is Louis Cognet, Le Jansénisme (Paris 1964). See also Nigel Abercrombie, The Origins of Jansenism (Oxford 1936), and Sedgwick, Jansenism.

49 Alberigo, 'L'episcopato'; C. F. Black, 'Perugia and Papal Absolutism in the Sixteenth Century', English Historical Review, 96 (1981), 509-39; Prodi, 'Borromée'.

50 Procès-verbaux, iii, pp. 279-80.

51 Charles Hefele, Histoire des conciles d'après les documents originaux, 11 vols (Paris 1907-52), i, p. 776.

52 Procès-verbaux, ii, pp. 51-6.

53 Charles de Montchal, Remonstrance faite à la reyne de la part de l'assemblée générale du clergé de France, par Messire Charles de Montchal archévesque de Toulouse, touchant l'affaire de Messire René de Rieux évesque de Léon (n.p. 1645), p. 2; Blet, Clergé . . . monarchie, ii, pp. 24-5.

54 Procès-verbaux, ii, pp. 59-60; Blet, Clergé . . monarchie, i, p. 313.

55 Procès-verbaux, ii, p. 55.

56 Blet, Clergé ... monarchie, ii, p. 28.

57 Montchal claimed in 1645 that the judgement against Rieux was 'a notable prejudice' to all French bishops: Montchal, Remonstrance, p. 1.

58 Blet, Clergé . . monarchie, ii, p. 58.

59 AN, G8*652, 14 October; Recueil des actes, ii, pp. 446-50.

60 Blet, Clergé ... monarchie, ii, p. 60-1; Pierre Blet, 'Le Nonce en France au xviie siècle. Ambassadeur et délégué apostolique', Revue d'Histoire Diplomatique, 88 (1974), 248; Pierre Blet, Histoire de la représentation diplomatique du Saint-Siège (Vatican City 1982), p. 373.

61 See, for example, Nicolas Pavillon's reference to the 1650 Assembly in Charles-Hugues Lefebvre, Vie de Monsieur Pavillon, évêque d'Alet, 3 vols, (Utrecht, 2nd edition 1739), iii, p. 268, Pavillon to the bishops of Narbonne province, 25 April 1668. Pavillon included a copy of the letter that the Assembly sent to all bishops to describe its principles. 
62 AN, G8*653, 31 May (1655).

63 Ibid., 8 June: 'L'intérêt de nos confreres [est] celui de l'épiscopat . . . rien de si dangereux que de laisser introduire une façon nouvelle de procéder contre les évêques de France, qui les puisse rendre coupables sans accusation et les faire condamner sans aucune forme de jugement.'

64 On Jansenist Augustinianism, see Abercrombie, Origins, pp. 125-58, and Henry de Lubac, Augustinianism and Modern Theology, trans. Lancelot Sheppard (London 1969), pp. 34-92.

65 René Rapin, Mémoires du P. René Rapin sur l'église et la société, ed. Léon Aubineau, 3 vols (Paris 1865), i, pp. 370-1.

66 There is no recent biography of Gondrin, but see Georges Dubois, Henri de Pardaillan de Gondrin, archevêque de Sens (1646-1674) (Alençon 1901). Gondrin's pastoral letter is held in BN, Ms. Baluze 122, fos 5-11.

67 Recueil des actes, i, p. 262.

68 Ibid., p. 310.

69 Ibid., p. 302.

70 For the bishops' biographical details, see Bonnot, Arnauld, Étienne Dejean, Un prélat indepéndant au xvii siècle. Nicolas Pavillon évêque d'Alet (1637-1677) (Paris 1909), Jean Gaillard, Un prélat Janséniste. Choart de Buzenval, évêque de Beauvais 1651-1679 (Paris 1902), and JeanMarie Vidal, François-Étienne de Caulet évêque de Pamiers (1610-1680) (Paris 1939).

71 The delegates were the archbishops of Toulouse and Bourges and the bishops of Lavaur, Lombez, Lodève, Saint-Malo, Soissons, Mende and Dol: Pierre Blet, 'Louis XIV et les papes aux prises avec le Jansénisme', Archivum Historicae Pontificae, 31 (1993), 109-92; 32 (1994), 79-92.

72 Antoine Arnauld, Les Oeuvres de Messire Antoine Arnauld docteur de la maison et societé de Sorbonne, 43 vols (Paris 1775-83), xxiv, p. 547: 'Ils ne peuvent être jugés en prémiere instance que par douze de leurs Confreres, non choisis à la volonté de ceux qui les voudroient faire condamner; mais pris de leurs provinces, et présidés par leur Métropolitan.' See also Lefebvre, Pavillon, iii, p. 267, Pavillon to bishops of Narbonne province, 25 April 1668: 'Nous ... serions de pire condition que tous ceux des autres Ordres, si nous étions assujettis à n'avoir pour Juges qu'un petit nombre de Commissaires, tels qu'il plairoit au Pape de les choisir.'

73 In 1657, Antoine Arnauld devised a distinction between droit and fait to allow Jansenists to subscribe to the Formulary. He declared that he adhered to the papal condemnation of the five propositions (droit), but believed the pope to be mistaken regarding the presence of these in the Augustinus (fait): Cognet, Jansénisme, p. 64.

74 Arnauld, Oeuvres, xxiv, p. 82; Blet, 'Louis' (1993), 116-17.

75 The royal minister, Hugues de Lionne, cited in Blet, 'Louis' (1993), 121: 'Un mois ne se serait pas passé sans voir tous les évêques de France engagés hautement en faveur . . . de leurs collègues.'

76 Arnauld, Oeuvres, xxiv, p. 547.

77 Nicolas Choart de Buzenval (bishop of Beauvais), Gilbert de Choiseul (bishop of Comminges) and Alphonse III Delbène (archbishop of Orléans) also refused to accept the papal brief without reservations. The papacy, however, concentrated on pressurising Gondrin to retract his pastoral letter and submit to Innocent X's constitution or face papal judgement: Blet, Clergé . . monarchie, ii, pp. 191, 212.

78 Lettre escrite a monseigneur l'évesque de Chaalons par monseigneur l'évesque d'Alet, touchant la signature du Formulaire, 1661 (n.p. n.d.), p. 1: 'Les Évesques ne doivent point signer ny faire signer en vertu du prétendu decret et délibération de cette Assemblée.'

79 Henri Arnauld, Response de monseigneur l'évesque d'Angers à la lettre de monseigneur le nonce, du 29. aô̂st 1662 (n.p. n.d.), p. 10: 'L'entreprise d l'Assemblée . . qui s'est voulu attribuer l'autorité de Concile national, et le pouvoir d'imposer des loix et des peines à tous les Évesques . . . est une raison suffisante à un Évesque qui aime son caractère de ne pas consentir à une usurpation si préjudiciable à sa dignité.' See the 1667 letter of the four bishops to Clement IX in Arnauld, Oeuvres, xxiv, pp. 450-6, for a repetition of this argument. 
80 Martin de Barcos, Correspondance de Martin de Barcos abbé de Saint-Cyran avec les abbesses de PortRoyal et les principaux personnages du groupe Janséniste, ed. Lucien Goldman (Paris 1956), p. 262, Barcos to Pavillon, 10 April 1657.

81 Arnauld, Response . . nonce, p. 7.

82 The bishops of Comminges, Conserans, Luçon, Noyon, Saintes and Vence were amongst those to issue pastoral letters that distinguished between fait and droit and requested only exterior respect for the faits of the papal constitution. Other bishops allowed their clergy to sign after making verbal distinctions between droit and fait: Blet, 'Louis' (1993), 135; Gaillard, Choart, p. 225.

83 Lettre de plusieurs prélats de France à N. S. P. le pape Clement IX sur la cause des quatre évesques, 1 décembre 1667 (n.p. n.d.), pp. 1-2.

84 BN, Ms. 14428(i), fo. 98r-v: 'Il est bon de les observer autant qu'il est possible, si ce n'est aux cas, ou on venoit qu'il arriveroit quelque inconvenient notable dans les diocèses particuliers.'

85 Antoine Godeau, Lettre éscrite au roy par monseigneur l'évesque de Vence, touchant la signature du Formulaire, 15 octobre 1661 (n.p. n.d.), p. 3; Antoine Gadeau, Résponse de monseigneur l'évesque de Vence à la lettre du roy, pour la signature du Formulaire pur et simple, août 1662 (n.p. n.d.), p. 4.

86 A. Cognet, Antoine Godeau évêque de Grasse et de Vence (Paris 1900), p. 485, Godeau to Henri Arnauld, 12 July 1661.

87 Henri Arnauld, Résponse de monseigneur l'évesque d'Angers, à la lettre que monsieur de Lionne lui avoit écrite, après avoir présenté et leu au roy celle dudit sieur évesque à sa majesté. Du 6. juillet 1661 (n.p. 1661), pp. 2, 7: 'Chaque Évesque a le pouvoir de régler les choses dans son Diocèse selon la lumière que Dieu luy donne, pour luy rendre conte un iour de son administration.'

88 Ibid.; Arnauld, Oeuvres, xxi, pp. 237-8.

89 Recueil des actes, i, p. 214: 'Toute l'autorité de l'Église Gallicane, en ce qui regarde la doctrine et les règlements de la discipline ecclésiastique, réside en cette Assemblée Générale, qui est . . . un concile national.'

90 Marca repeated this argument in 1661 when the Assembly imposed signature on all ecclesiastics: ibid., pp. 281, 320; G8* 657a, 11 January.

91 Ch. 1, p. 31.

92 Recueil des actes, i, p. 320; G8*657a, 11 January.

93 William Doyle, Jansenism (Basingstoke and London 2000), pp. 45-90.

94 Blet, Louis XIV et le saint siège, pp. 429-80.

95 Martimort, Bossuet, pp. 443-79. I have used the version of the articles printed in Louis Ellies Du Pin, Histoire ecclésiastique du xviie siècle, 4 vols (Paris 1714), iii, pp. 533-6.

96 Blet, Assemblées, pp. 248-362; Martimort, Bossuet, pp. 361-479; Orcibal, Louis XIV, pp. 3-11. See ch. 5, pp. 158-62, for further discussion of the articles.

97 Ch. 5, pp. 158-9, contains a short discussion of article 1 which dealt with papal and royal relations.

98 Bossuet also famously articulated these beliefs in the sermon that he delivered at the opening of the 1682 Assembly. Adopting a conciliatory argument, designed to avoid raising papal hackles, he endorsed papal primacy and plenitude of power, but went on to warn that papal power should be wielded according to the canons and laws of the church. He then affirmed that there existed no higher authority 'than the whole Church together', as put into practice by the councils of Pisa and Constance, whose 'maximes demeureront toujours en dépôt dans l'Église catholique': Jacques-Benigne Bossuet, Oeuvres oratoires, vi, pp. 86-138. See also Jacques-Benigne Bossuet, Correspondance de Bossuet, ed. C. Urbain and E. Levesque, 14 vols (Paris 1909-23), ii, pp. 271-82, Bossuet to Cardinal d'Estrées, 1 December 1681, in which Bossuet described his desire to defend gallican liberties without diminishing papal grandour.

99 Mémoires et journal sur la vie et les ouvrages de Bossuet, ed. François Guettée, 4 vols (Paris 1856), i, pp. 10-11: ' . . . un coup d'une grande importance de relever l'ancienne doctrine de France par l'autorité des évêques'. 
100 Gérin, Recherches, pp. 142-3, Charles-Maurice Le Tellier to d'Estrées, 3 May 1681.

101 Gaillard, Choart, p. 230, 264-5, 334.

102 Cognet, Godeau, p. 485, Godeau to Arnauld d'Andilly, 4 March 1662; Bossuet, Correspondance, v, pp. 40-1, Bossuet to Leibnitz, 15 August 1693: 'Que les évêques . . . peuvent témoigner leur foi . . . par un jugement exprès dans une assemblée légitime . . . ce corps étant infaillible, l'assemblée qui le représente véritablement, c'est-à-dire le concile, jouit du même privilège'; François Gaquère, Pierre de Marca, sa vie, ses oeuvres, son gallicanisme (Paris 1932), pp. 136-40; Arnauld, Oeuvres, xxii, pp. 200-1.

103 Paul Broutin, 'Le Concile de Bordeaux de 1624. Recherches sur la tradition pastorale en France après le Concile de Trente', Nouvelle Revue Théologique, 72 (1950), 409; Gouyon, Introduction, p. 268.

104 Gondrin, Felix Vialart, Gilbert de Choiseul and Dominique de Ligny respectively: Cognet, Jansénisme, p. 82.

105 Blet, 'Nonce', 23444.

106 Haan, ed., Correspondance du nonce, p. 433, Silingardi to Aldobrandini, 22 May 1600.

107 This was a political tactic by the crown, part of Richelieu's campaign to increase royal control of the church by placing episcopal appointments entirely in the hands of the monarchy. It was in this context that Richelieu was rumoured to have hatched a plan to establish himself as patriarch of France. However, this proposal was never precisely formulated by the cardinal, and appears to have been simply a scare tactic to unnerve the papacy: Church, Richelieu, pp. 309-16; Martimort, Bossuet, pp. 121-2.

108 Blet, Clergé . . . monarchie, ii, pp. 60-1; Blet, Assemblées, pp. 386-9; Blet, 'Nonce', 248-50.

109 Broutin, Réforme, ii, p. 534.

110 Bernard Chedozeau has shown that Pavillon's concern for the publication of religious literature in the French tongue stemmed from his desire to direct the spiritual and moral formation of his clergy, and not from a wish to distinuguish the French church from Rome. Moreover, his Rituel, condemned by Rome, was praised by a number of French bishops, including Godeau: Bernard Chedozeau, 'La Formation du clergé à Alet pendant l'épiscopat de Nicolas Pavillon (1639-1677)', Chroniques de Port-Royal. Actes du colloque tenu à Alet (Pari 1982), pp. 60-78; Godeau, Lettres, pp. 361-2, Godeau to Monseigneur N. (n.d.).

111 Ch. 5, p. 158.

112 Camus, Unite, pp. 129-30; Antoine Godeau, Remonstrance du clergé de France, faite au roy, la reyne regente s amere presente, le 7. aoust 1651. par reverend pere en Dieu Messire Antoine Godeau evesque de Grasse et Vence; assisté de monseigneur le prince de Conty, et de messeigneurs les archevesques et evesques qui se sont trouvez à Paris (n.p. 1651), p. 7; Bossuet, Oeuvres oratoires, vi, pp. 86-138. Cyprian's treatise On the Unity of the Church is contained in Ante-Nicene Christian Library: Translations of the Writings of the Fathers Down to A. D. 325, ed. Alexander Roberts and James Donaldson, 24 vols (Edinburgh 1867-68), viii, pp. 377-98.

113 Mathieu Bourlon, Remonstrance faites à l'assemblée générale du clergé de France. Sur diverses enterprises contre l'authorité épiscopale, et les libertez de l'église (Paris 1660), pp. 5-6; Godeau, Remonstrance, p. 7; de Paul, Correspondance, iv, pp. 268-9, Solminihac to de Paul, 2 November 1651.

114 Procès-verbaux, ii, p. 51.

115 Ibid., p. 59.

116 Ibid., xxiv, pp. 549-64.

117 Lefebvre, Pavillon, ii, p. 24.

118 Arnauld, Oeuvres, xxiv, pp. 561-2: 'gouverner . . . en qualité de ses Vicaires . . . la portion qui nous est échue, et prendre part en beaucoup d'occasions aux besoins de l'Église universelle'.

119 Ibid., i, p. 470, (Choart to Pavillon): 'Il n'y a qu'un épiscopat, dont chaque évêque possède une portion solidaire . . . l'Église a été commise par Jésus-Christ à tout le collège épiscopal ... chaque évêque a tellement son troupeau séparé, qu'il ne laisse pas d'être obligé de veiller . . . sur le troupeau entire de Jésus-Christ qui comprend tous les fidèles.' 
120 Henri Arnauld, Lettre de monseigneur l'évesque d'Angers. Au roy. Sur le sujet de la signature du Formulaire du clergé (n.p. 1661), p. 4; Henri Arnauld, Troisième lettre de monseigneur l'évesque d'Angers au roy, touchant la signature de Formulaire, par laquelle il répond à la lettre de sa majesté, du 28 aoûst 1662 (n.p. 1662), p. 1.

121 Lefebvre, Pavillon, ii, p. 30, Pavillon to a curé of Alet, 1661: 'Je suis dépositaire, aussi-bien que mes Confrères, de la Foi et de la Discipline de l'Église, et obligé de la soutenir et de la défendre, dans les occasions où j'ai sujet de croire qu'elle est blessée.'

122 Ibid., p. 177.

123 Persecution was regarded as an honour by many Jansenists, who understood it to be a means adopted by God to test their spiritual strength: Sedgwick, Jansenism, pp. 195-6; Alexander Sedgwick, The Travails of Conscience. The Arnauld Family and the Ancient Régime (Cambridge, Massachusetts and London 1998), pp. 257-8; Taveneaux, Jansénisme, pp. 35-44. Martin Barcos praised the bishops' heroic willingness 'de souffrir, de d'estre persecutez pour cette mesme cause': Barcos, Correspondance, p. 215, Barcos to Gilbert de Choiseul, 1654. 


\section{5}

\section{An uneasy alliance}

Despite the lamentations of seventeenth-century reformers about the inadequacies of religious belief and practice among the French population, they at least had the satisfaction of knowing that there was no real danger that protestantism would ever again challenge the privileged position of the Catholic church. Catholicism was the religion of France, of the majority of French people and of the royal family. Its clergy composed the first estate and were represented at provincial and national estates; they even had their own official Assembly in which their mainly episcopal deputies could voice the church's concerns and seek support from the crown. With privileges came responsibilities, however, for just as the church made demands on the temporal realm so it sought to gain from its connections with the church. As the self-proclaimed leaders of the French church, the bishops were at the centre of this far from straightforward exchange.

The topic of church-state relations is a vast one, only aspects of which relate directly to the episcopate and episcopal ideology. What follows is not a full-scale analysis of church-state relations per se, since this would merit an entire book of its own. ${ }^{1}$ Yet, having explored the episcopate's vision of its hierarchical role within the church, we must turn to its relationship with that other great institution, the French monarchical realm. It is clear that many bishops had an ambivalent attitude towards the temporal government for, despite realising the immense benefits that it could and did bring to them and to their church, they proved acutely suspicious of its tendencies to undermine their jurisdictional liberty and dignity. They fought a running battle throughout the century to ensure that these principles would be safeguarded for posterity. Ultimately, however, the episcopate was unable to halt the persistent squeeze that the guardians of the monarchical state placed on its model of episcopal power.

The episcopate's struggle was made all the more difficult because of the pervasive grasp of political gallicanism on many of the guardians of the realm's public interests. Over the course of the seventeenth century, its central tenets gained increasing credence among jurists, royal officials and parlementaires alike, 
and were articulated and publicised with consummate skill by writers like Pierre Dupuy. ${ }^{2}$ Political gallicanism coloured their attitude towards the pope, for it assumed that he held no power of jurisdiction in France and that the king answered to no one but God for his behaviour. However, it also informed their actions towards the French church and its leading hierarchical representatives, the bishops. Imbued with a dogma that presumed that the gallican church should be independent of Rome, political gallicans also unrelentingly sought to place it firmly under the control of the temporal realm. Although the seventeenth-century episcopate did contain some political gallicans like the politique archbishop of Reims, Charles-Maurice Le Tellier, this form of gallicanism was of a rather different hue from that of the many bishops who can be identified as episcopal gallicans. They found it impossible to stomach a notion of secular supremacy that dared to dictate to the consecrated episcopal leaders of God's church by controlling or appropriating their jurisdictional powers.

The bishops' situation was also particularly complicated by the fact that the episcopate was a child of the crown, with intimate ties to its secular family. Since 1516, the reigning monarch had chosen his bishops, subject to papal approval. In the seventeenth century, that prerogative frequently meant that many bishops owed loyalty not only to their monarch, but also to those who had guided them towards royal approval and into their seats. Joseph Bergin has carefully traced the labyrinth of paths to the episcopate, clearly identifying the many bishops who owed their episcopal careers to Richelieu, Mazarin and members of the royal family. Personal favour, clientage and royal service could all bring their rewards: among those who found this out were the diplomats Arnauld and Malier du Houssay, the former intendant Bosquet, the agent general La Barde and Richelieu's clients, Jaubas de Barrault and Etampes. ${ }^{3}$ Bergin has also demonstrated that, through the century, the overwhelming majority of prelates emerged from the nobility, with some owing their positions to ambitious relatives who acted as their patrons or who had climbed the social ladder far enough to attract royal notice. Without his brother's ascent to political dominance in Louis XIII's reign, Alphonse Richelieu might never have become the bishop of Aix and archbishop of Lyon, and Nicolas Colbert certainly owed his terms in Luçon and Auxerre to the rising fortunes of his envied family under Mazarin and Louis XIV. ${ }^{4}$

Once seated, many bishops retained full-blown or residual loyalties to their patrons, a thorn in the side of episcopal reformers who, while recognising that nobles were the natural leaders of society, knew that bishops could be pressurised and persuaded into using their office to benefit their relatives and friends..$^{5}$ Equally, political obligations and the prospect of further favour or reward could influence episcopal actions. The court prelate and Mazarin aide Pierre de Marca, for example, was initially instrumental in the campaign to 
produce the 1657 articles in Assembly but, eventually, made a complete aboutturn to seek their burial in accordance with the government's wishes. Even when a bishop was not an intimate créature of a leading political figure, he still had to represent the crown locally, keep the government informed on regional affairs and cultivate political and social stability. In the extraordinary circumstances of war and rebellion, bishops were expected to act as peace brokers on the crown's behalf: ${ }^{6}$ during the Fronde, Henri de Béthune, archbishop of Bordeaux, successfully defused a potentially explosive political and social crisis in his province by mediating between the governor and parlement of Guyenne. ${ }^{7}$ More routinely, bishops were instrumental in controlling popular festivities, eradicating superstitions and limiting feast days, activities that were perfectly attuned to the government's desire to maintain social order. ${ }^{8}$

Bishops, therefore, had a foot in each camp, ecclesiastical and temporal. This raised fundamental questions about their identity and role. To whom did they owe their loyalty? How deeply should they become involved in secular affairs? What should inform their behaviour when episcopal and secular ambitions appeared to clash? Of course, other bishops had encountered these dilemmas through the centuries, but the pressures had perhaps never been quite so intense. Seventeenth-century French bishops functioned in a regime that demanded much of its nominees and tempted them with opportunities to amass fortunes and reputations. Their quandary was heightened by the prevailing climate of reform, which tended to spotlight starkly the dangers of selfishness and worldliness that menaced any prelate who delved too deeply into secular affairs. Yet it simultaneously suggested that bishops defend themselves and the church against those who would injure their dignity. Quite often those threats came from within the governing hierarchy itself, but just as the episcopate and the popes clashed over governmental boundaries, so too the bishops and the crown's representatives found themselves at odds over contested realms of jurisdiction at both local and national levels. If bishops were to protect their authority against an incursive state, then it was surely necessary for them to pay attention to politics, to become involved in litigation or to visit the court.

Despite, or sometimes because of, the episcopate's customarily intimate relationship with the government, the Assembly of Clergy frequently played host to intense power struggles between the guardians of the church and the state. It is no longer fashionable for historians to write of the absolute monarchy of Louis XIV, for the image of absolutism hid a governmental system that worked on a shifting pattern of alliances, patronage and negotiation. ${ }^{9}$ Yet although monolithic absolutism has been revealed as a flimsy construction, there is no doubt that governmental power grew steadily over the course of the seventeenth century. ${ }^{10}$ Like every other section of the population, the episcopate 
experienced the effects of the crown's assertiveness. However, just as local notables and even peasants could find ways to challenge royal power, so too the bishops could use their assets to negotiate their own objectives. Quite often, the Assembly played host to collusive transactions, for the bishops and the crown sometimes shared the same goals, though perhaps for different reasons. As the holders of the French church's purse strings, the bishops could occasionally use its assets to bargain for advantages in jurisdiction. That produced a positive result in 1695 when the bishops managed to squeeze official confirmation of their authority over the lower clergy from a crown desperate for ready cash to fuel its war. Yet this was just one episode in a constant financial wrangle between the church and the crown, in which the crown ultimately held the upper hand. From 1665 onwards, the don gratuit became a customary donation rather than an extraordinary subsidy, despite the Assembly's protest that it was a voluntary contribution rather than a fixed obligation. The clergy were now wrong footed, for the precedent was set: it was not a question of whether they would give financial aid but of how much they would have to offer. That significantly reduced their ability to use the contribution as a bargaining tactic. ${ }^{11}$

The bishops were not always able to bargain successfully with the crown, and it was certainly not an easy task to police every effort by the state's representatives to usurp their jurisdictional power. To protect ecclesiastical rights against temporal encroachment, they had to concern themselves with two distinct areas of vulnerability: their own prerogatives and those of the church as a whole. Of course, for the episcopate, one could never truly separate the two, for attempts to limit its power ultimately damaged the entire church. It was its duty to defend the church from secular intrusions which would dishonour its roles of leadership and protection and leave bishops as the simple lackeys of the state. Although the bishops generally concentrated exclusively on their jurisdictional rights in their quarrels with other clergy, they understood their struggles with the monarchy and its representatives in a far more expansive way. That did not remain an implicit or unconscious assumption, but was articulated at every opportunity: every attack on the church was an assault on the bishops who governed it.

For this reason, the episcopate needed to maintain a vigilant eye on government officials, and to react quickly and vigorously when they attempted to assume or control episcopal powers. Significantly, the bishops never directed their anger towards the king; rather, they preferred to blame his ambitious and deceitful servants and to lambaste them for their criminal attempts to undermine episcopal and ecclesiastical authority. Alternatively, they attacked the state in abstract, carefully avoiding any suggestion that they might harbour treasonous sentiments. This was an attitude befitting an episcopate that played a major role in the perpetuation of the theory of divine right; in fact, one of its 
most famous members, Bishop Bossuet, produced the ultimate vindication of the king's absolute and God-given right to rule in his famous treatise, Politique tirée des propres paroles de l'Écriture sainte..$^{12}$ It also fitted perfectly with the first of the 1682 Articles which confirmed that the pope held no jurisdiction over the king's temporality. ${ }^{13}$ Yet the episcopate had certainly travelled a long way since its energetic campaigns, several decades earlier, to reject this very doctrine. ${ }^{14}$ Those particular episodes, in 1614 and 1625, were complicated by the fact that the bishops were also defending the church's exclusive prerogative to judge matters of faith. When the third estate introduced an article denying the pope's temporal power to the 1614 Estates General, the episcopal deputies reacted swiftly and furiously to denounce this lay attempt to encroach on the territory of the first estate. ${ }^{15} \mathrm{~A}$ decade later, one of their colleagues, Leonor d'Etampes, inadvertently sparked another row when he was chosen by the Assembly to respond to anonymous pamphlets which defended the pope's right to depose rulers who were heretical or persecuted the church. Moving to the other extreme, Etampes drafted a censure that endorsed the independence of secular rulers and advocated absolute obedience to them at all times. ${ }^{16}$ Horrified that he had exceeded his remit, his fellow bishops then desperately sought to backtrack by convening at Saint-Genevieve to issue a disavowal of the declaration. They did so despite the disapproval of the Paris parlement which fought desperately to prevent them from either deliberating on or judging the issue. ${ }^{17}$ Behind the bishops' actions in these incidents lay a emphatic declaration of the church's rights: no secular body could prevent the church from passing judgement on spiritual matters, and no member of the laity could attempt to judge Catholic doctrines. More particularly, this was an assertion of their rights, based on the notion of episcopal leadership. As bishops, they were obligated to ensure that the church's unique role as the definer of faith was protected. In neither case, however, did the bishops expressly raise the question of their specific role in judging matters of faith. It would not be until the 1650s, in the Formulary crisis, that they would need publicly and explicitly to address that problem.

These were arguments that turned on the capacity or otherwise of secular institutions and individuals to become involved in spiritual affairs. In both, the bishops were entirely successful in ensuring that neither the opinions of the gallican third estate nor those of the parlement were imposed as official dogmas on the French church. However, with the exception of one further occasion, in 1665 , the episcopate did not need to worry that its spiritual jurisdiction would be usurped. ${ }^{18}$ Instead, it fought to defend its disciplinary jurisdiction. Still, the same fundamental principle was at stake in both kinds of dispute: the laity were not permitted to involve themselves in affairs of religion. It was the leaders of the church who should deal with all ecclesiastical causes, of both faith and discipline, given their special nature. In these struggles, the episcopate's resistance 
to what it saw as temporal threats to its jurisdiction had much in common with its opposition to the supposed privileges of regulars and to the curés' Richerism. Like the lower clergy, the state had tangible gains to make if it could manipulate the episcopate's jurisdiction. The French church was composed of thousands of clergy, who were largely immune from secular jurisdiction. It administered its own system of discipline according to canon law and under the oversight of diocesan bishops. In short, this virtually autonomous institution was a lucrative pool of plunder for those crown officials who cast covetous eyes over its jurisdiction, its properties and its personnel. In doing so, they threatened the power of its governors, the bishops.

Of course, for these officials it was firmly within the government's remit to intervene in the church's spiritual and disciplinary affairs. That principle became abundantly clear when the crown decided to drag the new archbishop of Paris, Cardinal de Retz, into its courts in early 1654. His fresh status as archbishop swung the episcopate's attention to his cause, spurring it to defy this civil effort to judge a bishop. It did so for two reasons. In the first place, the clergy were traditionally exempt from civil trials: that principle would certainly apply to a bishop of the church. Second, the Council of Sardica had elaborated detailed procedures for the trial and judgement of bishops. No secular authority could presume to ignore that episcopal right and to judge or punish any bishop suspected of misdoing. Revealing his usual adept taste for propaganda, Retz successfully appealed to the episcopate's sense of unity and communion in his calls for its support, loudly complaining that the crown treated its brother as 'a bandit or captain of thieves'. ${ }^{19}$ Indeed, this was a common tactic used by bishops to inspire their brethren to resist the encroachments of the temporal power, just as they sought to cultivate a common sense of purpose and identity in their disputes with the popes and lower clergy. Godeau complained heartily about secular infringements, and pointed out that 'the bishops making only one bishop, the injury of one is the injury of all, or rather of the whole church. ${ }^{20}$ Faced with the kind of concerted episcopal defiance that Godeau sought to inspire, the crown felt forced to request that Retz be tried by papal commissioners, and officially recognised that it had overstepped the mark in attempting to pursue his case in a secular court. ${ }^{21}$ That was a significant retraction and a pleasing victory for the episcopate.

The convictions of political gallicans were far too extreme for even the most gallican of bishops. While they happily endorsed the view that the pope could not intervene in the government of the French church, they were equally convinced that it was the episcopate who should manage its affairs, and that the temporal government had no business initiating interventions into its domain. These men were episcopal gallicans first and foremost, and although that category incorporated elements of political gallicanism it did not stop them from 
regularly clashing with the political gallicans who represented the secular government. They were even, on occasion, perfectly willing to ally themselves with the papacy to deflect incursions on their territory: both Rome and the bishops thoroughly disagreed with the crown's plan to try Retz. Most of them also took issue with the complete veto by political gallicans on the decrees of the Council of Trent, for they did not see why these would inevitably extend the tentacles of papal power in France or damage episcopal jurisdiction. In contrast, the crown never showed itself to be more than superficially enthusiastic towards Trent's formal publication because, on several counts, the Council's decrees contradicted French laws and gallican liberties. The ever vigilant and intensely gallican Paris parlement hotly opposed all efforts to promulgate the decrees officially. ${ }^{22}$ Yet, besides publishing the decrees in their synods and adopting the Tridentine programme in their dioceses, the bishops repeatedly requested that the Council's decrees be given legal status in France in order to ensure its implementation. After the clerical Assembly of Clergy had accepted them in 1615, Cardinal de La Rochefoucauld repeated its call for legal confirmation in 1626. Among those who had pleaded for publication before La Rochefoucauld were Cardinal Du Perron, Jérome de Villars, André Frémiot, Camus and Harlay. ${ }^{23}$ By 1660, however, the bishop of Autun's was an isolated voice when he requested that the decrees be published officially. ${ }^{24}$ As the century progressed, the episcopate grew resigned to the fact that legal force would not be granted to the decrees, and its appeals for this halted.

Despite their tugs of war with successive popes, the bishops' sustained support for the publication of Trent's programme highlights their sense of membership within the universal Catholic church and their desire that the French church should align itself with general Catholic discipline and doctrines as far as possible. On occasion, however, the temptation to use Trent's ambiguous status in France to slip out of tricky situations proved irresistible. Frequently, the bishops were happy to rely on its decrees to bolster their authority, as when declaring their disciplinary power over regulars and curés. Yet it was not always convenient to do so, for Trent did not invariably serve their purpose: the bishops simply ignored the Tridentine decree that confirmed the pope's right to judge episcopal causes, and concentrated on the decrees of the ancient Council of Sardica instead. Certainly they recognised that this was not in itself a watertight defence. At least two of them felt obliged to brace the decrees of Sardica by pointing out that the Council of Trent had not been officially adopted in France. Both Montchal and Gondrin must have known that the Assembly of 1615 had received the decrees on behalf of the French church, but they carefully chose to ignore that fact and to play on its exclusion from the law of the land in order to present a winning argument for the episcopal camp. 
At the same time, the episcopate's persistent calls for Trent's publication reflect its view that the church and the state, the twin pillars of society, were joined in a mutually reinforcing relationship that ensured order in society. This was an entirely conventional view for seventeenth-century churchmen to take. The episcopate simultaneously drew on the notion that both church and state had their own spheres of jurisdiction. In principle, therefore, any infringement on the ecclesiastical realm by the secular was a direct attack on, or 'a sacrilegious usurpation' of, the rights of the church. ${ }^{25}$ In practice, however, this distinction was extremely difficult for the bishops to achieve, not simply because the secular authorities seemed to violate it at every opportunity, but also because the episcopate itself tended to blur the boundaries whenever it suited its ends. That happened on numerous occasions. Bishops often called on the secular arm to ensure that their regulations were enforced. ${ }^{26}$ The most obvious instance of the church's reliance on the state occurred in 1664, when the king issued an edict obliging all clergy to conform to the anti-Jansenist Formulary. ${ }^{27}$ The bishops could and did justify this kind of collusion by claiming that the state was dutybound to support them whenever it could, for their work served greater purposes, the glory of God's church and the salvation of souls. Ultimately, therefore, despite the importance of the temporal order, it was inferior to the church, the 'column and firmament of truth'. ${ }^{28}$ This was much less radical than it might seem, for the episcopate did not intend to overthrow the state; rather, it sought to use the state's armoury to protect its position. It was acceptable, therefore, for the crown's officials to intervene in the bishops' affairs when they specifically requested their assistance. Otherwise, these should be allowed to make full and exclusive use of their power of government. It was, however, a difficult balance to achieve: for in allowing secular intervention in their affairs on some occasions the bishops simply whetted the appetites of officials.

This was a dilemma that was most vividly illustrated when the bishops occasionally resorted to appels comme d'abus, one of the favourite devices used by parlementaires to subvert episcopal authority. ${ }^{29}$ Appels were enticing traps for bishops: they detested the fact that these enabled the secular powers to steal their jurisdiction, but they offered short-term gains, while making it extremely difficult for the bishops to condemn anyone else who used them. Of course, each diocese possessed its own court to deal with ecclesiastical causes but, to the exasperation of their prelates, individual ecclesiastics pronounced guilty in these frequently appealed to the sovereign parliamentary courts in order to have the judgements against them overturned; it was the 'fashionable' appels comme d'abus that enabled them to do so. In theory, these appels were limited to cases in which the ecclesiastical judge 'notoriously' exceeded his power or when there was a 'manifest enterprise' against the liberties of the gallican church..$^{30}$ In practice, the sovereign courts frequently heard all kinds of ecclesiastical cases, usually 
claiming that these potentially related to the police of the realm and hence came within their jurisdictional remit.

This particularly bothered bishops when they attempted to implement Tridentine innovations in their dioceses. Time and again, they complained that local authorities obstructed their activities and championed clergy who rebelled against their discipline on the basis of time-honoured customs. Most frequently, recalcitrant clergy appealed to their local parlements in order to have troublesome episcopal ordinances overturned. So, for example, the religious orders quite often appealed to their provincial parlements in disputes concerning the degree of episcopal jurisdiction over their members, as happened in Henri de Sourdis's dispute with the regular clergy of Bordeaux during the 1640s. Even though Sourdis had issued an interdict against the regulars, the Bordeaux parlement willingly granted them leave to continue their pastoral care after they brought an appel against the archbishop's judgement. ${ }^{31}$ The secular courts did not limit themselves to cases involving the regular orders: Harlay's dispute with the curés of Rouen during the late 1620s involved the provincial parlement when, reacting to complaints by members of the parish clergy, it issued an arrêt forbidding the archbishop's officials from proceeding against the curés. ${ }^{32}$ François Hallier recalled this particular episode over twenty years later in a work commissioned by the Assembly to highlight its grievances against secular officials. Declaring that the problem of usurpation of ecclesiastical justice had worsened drastically within the previous half-century, Hallier incorporated Harlay's experience as an illuminating, if infuriating, example of the manner in which the church was persistently stripped of its 'honour and authority [and] discipline'. . $^{33}$

An exasperated episcopate repeatedly declared these kinds of interventions by the secular courts to be absolutely unacceptable, and insisted that ecclesiastical cases should not be resolved within the framework of secular justice. Successive bishops judged appels to be the prime manifestation of a general pattern, whereby the servants of the crown persistently subverted episcopal authority. By 1635, the episcopate's exasperation had reached such heights that it seized its chance to denounce this sabotage in the Assembly's cahier, and it repeated its protests in 1645,1655 and $1675 .{ }^{34}$ The cahier began with a stream of embittered objections to civil justice which drew attention not only to the autonomy of the church in religious affairs but, specifically, to the power of embattled bishops in their dioceses and over clergy: municipal officials chose preachers and refused those delegated by local bishops; they dictated the times for religious services and claimed precedence in local assemblies. Some of these complaints tended to revolve around relatively minor issues of honour, though in seventeenth-century France, precedence in processions and assemblies was an important indication of rank and the episcopate obviously felt that its special status was not always being recognised. ${ }^{35}$ These common snubs together formed 
a continuing affront to an episcopate that prided itself on the privileges of its office. To defeat the various 'empiètements' on their territory, many bishops like François and Henri de Sourdis produced detailed ordinances prescribing the limits of civil jurisdiction and repeatedly forbidding the secular authorities to regulate feasts and preaching. ${ }^{36}$ But it was the appels comme d'abus which provoked their greatest displeasure: '[The judges] suspend the execution of ordinances . . ., overturn the ecclesiastical judgements, they take cognisance of all the personal causes of ecclesiastics ... which are very great enterprises against the jurisdiction of the Church. ${ }^{37}$

Yet the discontentment revealed in the cahier was not simply a function of the fact that the secular authorities persisted in their efforts to squeeze episcopal jurisdiction. They simultaneously damaged episcopal dignity and status within the church and society. Early in the century, the bishop of Aire pointed this out in a remonstrance to the king, and it became a familiar refrain in the episcopate's assessments of its relationship with the temporal realm. Prelates were the judges, fathers and pastors of the faithful, argued Philippe Cospeau; to force them to plead before and to obey lay judges was a perversion of the true religious order because it placed the pastor beneath the sheep..$^{38}$ Equally, bishops were urged to challenge these insults to their authority and status, and to do so not simply on their own behalf, but for the benefit of the whole church. In 1660, Bishop Mathieu Bourlon presented a remonstrance to the Assembly, partly based on his own experiences in Soissons. He began by describing the offence to his authority when the civil courts interfered in ecclesiastical causes, then broadened his commentary to draw attention to the wellbeing of the entire church. Bourlon presented the episcopate as the courageous defender of the church, with responsibility for protecting its powers and rights against those aggressive jurisdictional rivals who violated ecclesiastical 'decrees and liberties' ${ }^{39}$ His rallying words did not fall on deaf ears, for other bishops certainly conceived their role in these fighting terms. Alain de Solminihac vigorously resisted the attempt by the parlement of Toulouse to release two ecclesiastics whom he had imprisoned for misconduct. He did so, he explained in 1650, because he knew that, as a bishop, he was obliged to defend the church's jurisdiction against illegitimate 'enterprises': 'Were it necessary to risk one's life for this, I would willingly do so in order to prove my case and conserve the jurisdiction of the church in its entirety. ${ }^{40}$ This willingness to oppose civil 'empiètements' on behalf of the church was, Godeau agreed, one of the most necessary qualities of a 'true Bishop'. ${ }^{41}$

A 'true bishop' was an apostle of Christ, and it was upon this ancient image that the bishops grounded their opposition to temporal officials. God granted their jurisdictional power so that they could 'establish the spiritual reign of Jesus Christ in the world'. Following the examples of the first Apostles, they 
should defend that gift so that it was neither abused nor eroded. Like Saint Paul, they were also bound to defend the sheep over whom they had been set. ${ }^{42}$ Underpinning that inspiring portrait was the assumption that a bishop's involvement in disputes should never be animated or in any way influenced by selfinterest or personal ambition; he should become involved in 'affairs of the world' solely for the 'service of Jesus Christ' ${ }^{43}$ Solminihac articulated that rule when he opposed the local parlement's effort to regulate the rules of his seminary in Cahors: 'I would willingly have dropped all the lawsuits for the aversion that I have for them, but I was forced by the vow that I took to conserve the rights of my church and by my obligation to watch over the conduct of souls with which I was charged.'

By distinguishing ecclesiastical interests from personal ambitions and profane affairs, bishops like Solminihac were able to respond to that particular episcopal worry: how to avoid being ruled by secular interests. It was sometimes necessary to become involved in temporal affairs, admitted the bishop of Cahors, when they threatened episcopal jurisdiction and ecclesiastical health, but the harvesting of his diocese's 'fruit' ought always to be a bishop's priority. Only if an affair directly bore on the spiritual health of the church and its faithful should he enter the minefield of secular politics and legalities. ${ }^{45}$ Of course, prelates were not required to detach themselves completely from the affairs of the world, for even Solminihac knew that this was impossible in seventeenthcentury society. Although Antoine Godeau and Louis Dony d'Attichy agreed that a bishop should display prudent reticence in tolerating opposition, they were careful to add that all prelates should invariably be prepared to defend 'the honour and liberty of the church' ${ }^{46}$ This advice was not difficult to manipulate, for virtually any issue could be deemed to have possible repercussions for the church and its bishops. François de La Rochefoucauld assuaged his conscience by developing this justification of his political activities. The cardinal was particularly sensitive to the accusation that he neglected his religious responsibilities in favour of his services to the crown. He also resented the fact that hard-line political gallicans insisted that bishops had no business meddling in affairs of state, even while they threatened to thrust themselves into the ecclesiastical realm. As a president and ordinary member of the Conseil $d u$ Roi, ${ }^{47}$ La Rochefoucauld knew that their criticism was directed firmly at him, but he found comfort in the example of Saint Augustine, who had assumed secular cares only when it became necessary for the spiritual welfare of his people. He was an advisor and custodian who ensured that the state did not embrace any doctrine or policy which was prejudicial to its subjects' salvation but, like La Rochefoucauld, he never actively sought secular office. ${ }^{48}$ La Rochefoucauld could also have drawn satisfaction from Jean-Pierre Camus's claim that bishops could legitimately act as royal advisors: as spiritual leaders, they were duty-bound to 
advise the faithful, one of whom was the king. ${ }^{49}$ Ultimately, however, La Rochefoucauld's conscience appears to have bettered him. Troubled by the long absences which prevented him from devoting his full attention to the faithful of Senlis, he eventually resigned the see to a hand-picked successor, Nicolas Sanguin, in 1622.

Contemporaries generally acknowledged that La Rochefoucauld was not a politique prelate, but one who had 'strayed into politics for non-political reasons' ${ }^{50}$ Yet although he was at least temporarily convinced of the validity of his defence, it could be manipulated by less scrupulous prelates to rationalise persistent immersion in affairs of state. Both Godeau and Dony were highly critical of bishops who spent all their time in politics or at court, scathingly describing them as base and unworthy of their office and as lacking in 'moral integrity'. Ideally, visits to court should be undertaken only 'for necessities and interests of God and the Church' and to advise the king on matters pertaining to his spiritual health. ${ }^{51}$ Godeau privately blasted the courtly episcopate of Pierre de Marca who, he believed, had been excessively worldly and insufficiently motivated by religious principles in his political activities. To solicit the court for favours was distasteful enough, Godeau observed caustically, but to live one's vocation as a politique was simply inexcusable. In many ways, Marca and other court prelates treated the episcopal office as 'a temporal dignity' to be won and retained by 'intrigue, favour, complaisance and cowardice'. From Godeau's perspective, however, it was 'a spiritual dignity and a continuation of the priesthood of Jesus Christ'. Episcopal activities, whether purely ecclesiastical or partially temporal, should always be motivated and directed by this fact. ${ }^{52}$ This interpretation of episcopal action informed the vocations of many bishops of a dévot stripe, and related closely to the opposition of prelates like Philippe Cospeau to France's anti-Habsburg and anti-papal foreign policy during the 1620s. Obviously, however, its canons stacked into a rather biased and lopsided understanding of the powers enjoyed by church and state, designed to ensure that the civil authority did not claim the right 'to use the church like a domain'. ${ }^{53}$

Despite the episcopate's successive demands that the 1635 cahier be registered and its suggestions implemented, it never managed to persuade the crown to do so. A quarter of a century later, Dony d'Attichy was obliged to lament the secular incursions that bishops still had to endure when he addressed the Assembly of Clergy. All those bishops then in Paris received a personal invitation to hear him applaud the example of Thomas à Beckett, who had not hesitated to advise his king of the abuses committed in his name or to impress upon him the fact that he would one day be forced to render account to God for his administration. Dony urged his fellow bishops to follow the saint's 
example, in '[speaking] efficaciously to the King and [awakening] his scruples by very respectful but very strong remonstrances, oral and written, to the fact that his officers violate with impunity . . . ecclesiastical jurisdiction ... and that it is for his honour and his conscience to prevent them.' Most substantially, he argued that a deteriorating situation could be remedied if the 1635 cahier was verified, the Tridentine decrees legally confirmed and the papacy requested to support the episcopate's struggle.

Dony was also one of several prelates who proposed that regular provincial councils be held to instil ecclesiastical discipline and encourage united episcopal leadership. This was an important proposal, ${ }^{54}$ and it was envisaged as a crucial element of the tough action that bishops should take to defend their jurisdiction: Dony also urged his confreres to refuse to execute lay judgements, to issue canonical penalties against officials who undertook these illegal transgressions, and to exercise strict control of the lower clergy. ${ }^{55}$ Yet he must have suspected that he and his colleagues were fighting an uphill battle. If he did, those misgivings were realised just five years later. In 1665, the parliamentary Chambre des Grands Jours d'Auvergne suddenly decided that it should increase the portion congrue of the lower clergy, and then allowed its commissioners to assume episcopal powers of visitation in the region. ${ }^{56}$ Worse still, at the same time the avocat général, Denis Talon, affirmed in parlement of Paris that 'temporal princes have the right to judge dogmas of faith and all ecclesiastical discipline' ${ }^{57}$

Naturally, the bishops were incensed at these wholesale assaults on their power, and slammed the unprecedented maxims as 'injurious and pernicious to the church' that they governed de droit divin as the Apostles' successors. ${ }^{58}$ Yet their sustained failure unambiguously to demarcate the boundaries of secular and ecclesiastical jurisdiction was at least partially responsible for Talon's emphatic plea. He had been responding to the failure of some clergy, including several bishops, to obey the 1664 royal edict against Jansenism. Members of the episcopate had been perfectly happy to allow the crown to assist the church in eradicating heresy by strong-arming Jansenists into signing a Formulary that was concerned with religious doctrine. Talon was able to inflate the crown's initiative and prominence in this collusion to suggest that the temporal authority possessed, equally with the leaders of the church, the power to judge questions of faith and discipline. After all, he believed that he possessed evidence to illustrate that it had done so in seventeenth-century France. His claim was simply too extreme for the episcopate, however, which considered itself to be the sole authority in morals and faith: 'The church [cannot] exist with several heads.' Even the king was a 'sheep' in spiritual affairs, bound to listen to the bishops, his pastors, to whom 'alone God gave the power to judge dogmas of faith' ${ }^{59}$ Yet the crown proved conspicuously reluctant to offer satisfaction when the bishops demanded that the decision of the Grands Jours decision be overturned and that 
Talon withdraw his assertion. ${ }^{60}$ It agreed to suspend the decisions of the Grands Jours but flatly refused to force a full retraction from the avocat. Finally, the Assembly had to censure his 'schismatic and heretical' plea itself. Learning from Mazarin's attempt to doctor its resolutions in 1657, it also took the precaution of sending copies of the procès-verbal to every bishop in France. ${ }^{6}$

In the light of the crown's steadfast refusal to accommodate the episcopate in 1665, it appears odd, at first glance, that it should agree to issue an edict some years later that seemed to offer the bishops security against secular interventions in their government. One of its stated purposes was to prevent the disorders that conflicts between church and state could produce 'to the detriment of ecclesiastical jurisdiction', and it spoke respectfully of the 'honours' due to the 'first order of our realm' ${ }^{62}$ In fact, the 1695 edict fell far short of the bishops' desires and painted a picture of their power that was partially at odds with their perception of the relationship between the ecclesiastical and temporal authorities. It was a declaration of secular competence over the church that perfected suited the gallican sentiments of the monarchy for, despite the claim that 'We desire that archbishops [and] bishops . . . may be maintained in all the rights . . . and advantages, that they enjoyed or had to enjoy until now' ${ }^{63}$ many of the articles contained stings in their tails. Although they confirmed the bishops' jurisdiction over the lower clergy and ordered parlements and officials to co-operate with and respect their ordinances, they completely failed to eradicate that bane of bishops' administrations, the appel comme d'abus. Indeed, the edict specifically affirmed that parlements could accept these appeals in an impressive range of cases, including those concerning 'divine services, church repairs, purchase of ornaments, the subsistence of parish priests, ... corrections of ecclesiastics' morals, and all other things concerning ecclesiastical discipline' ${ }^{64}$ With that deadly final phrase, the edict completely dismissed the bishops' century-long complaints and, equally emphatically, vindicated the interference of temporal officials in their rule. Finally, article 30 rejected the episcopate's dearly held conviction that it should be the principal arbitrator of doctrinal concerns by safeguarding the secular courts' right to redress 'scandal, and trouble of order and public tranquillity, and the contravention of ordinances, that the publication of [a] doctrine will have been able to cause' ${ }^{65}$

Of course, the episcopate did make some valuable gains from this edict, because its hierarchical authority over the pastoral activities of the lower clergy, regular and secular, was confirmed in secular law. But this was achieved at the price of surrendering some of its ideals to the practicalities of living under the ancien régime. Indeed, while the bishops at times managed to benefit from their privileged access to the Bourbon monarchy, they were obliged, overall, to forgo more than they won. Almost every hard-won victory was simultaneously a compromising defeat. That is nowhere more apparent than in the bishops' 
rather ambivalent response to the government's campaign to plunder the régale. This entire episode encapsulated their experience through the seventeenth century; for while the bishops were able to fight off papal pretensions, they never succeeded in breaking the persistent siege of episcopal and ecclesiastical jurisdiction by the secular realm. Nor did they manage to persuade the crown to accept their view of episcopal power and authority. The monarchy endorsed the episcopal vision when it served its interests. Otherwise, it simply followed its own rules.

Among the customary rights that the crown had formally agreed with the church was its power to collect the revenues of certain vacant dioceses (régale temporelle) and to nominate to benefices within these (régale spirituelle). Between 1673 and 1675, Louis XIV began to extend this privilege to every diocese throughout France. ${ }^{66}$ If the bishops had assumed their normal position, one would have expected a serious campaign of resistance to this wholesale invasion of their ecclesiastical territory. However, for men who were so sensitive to jurisdictional boundaries, they remained remarkably silent about it. Thirty-five of them actually formally approved the extended droit de régale in $1682^{67}$ and the Gallican Articles that followed, the first of which confirmed the king's supreme temporal authority. These Articles were then circulated to all the bishops of France, accompanied by the instruction that they should not tolerate any opinion that contradicted the doctrines in them. ${ }^{68}$

Only two bishops, Pavillon and Caulet, resisted the régale's extension, on the basis that the Council of Lyons (1274) had forbidden bishops to permit it, on pain of excommunication. ${ }^{69}$ With both displaying the stiff qualities that had enabled them to weather the Formulary dispute, they maintained their opposition through the 1670s and until their deaths towards the end of the decade. ${ }^{70}$ Each refused to take the oath of loyalty admitting the king's right to the régale in Alet and Pamiers, and, in 1675, declared that those who gained a benefice through it would be excommunicated. Under mounting royal pressure to submit, they then appealed to Rome, allying with Innocent XI, who issued two briefs in 1678 and one in 1680 which praised their steadfast resistance while condemning the crown's violations of the ecclesiastical domain. ${ }^{71}$

It has often been assumed that the ambitions of Louis XIV and his gallican ministers were the driving forces behind the publication of the Articles of 1682, but the crown was often far more conciliatory towards Rome than were its bishops during this episode. ${ }^{72}$ It certainly conceived the Assembly of 1682 to be a means of threatening the papacy into compromising its opposition to Louis's extension of the régale but it did not, as nineteenth-century ultramontane historians liked to think, need to bully the 'fatally weak' episcopal delegates into producing the four articles. ${ }^{73}$ Indeed, the episcopate is still occasionally characterised simplistically as the malleable instrument of the monarchy, but this is a narrow 
evaluation of its position which does not set the declaration within its full historical context and which tends to concentrate on its first article only. ${ }^{74}$ The bishops were certainly under some crown pressure to produce a remedy for the quarrel over the régale, and some proved uncomfortable with the tenor of article 1 . Yet to characterise them as spineless or cowardly fails to take account of the fact that three of the articles offered the episcopate particular benefits which seemed, if not to outweigh the disadvantages of article 1, to compensate for them. The bishops were quite prepared to defy successive popes in order to preserve these. Innocent XI and Alexander VIII made it perfectly plain that they frowned upon their behaviour by issuing strong declarations nullifying their approval of the crown's extension of the régale, ${ }^{75}$ and by refusing to accept the nominations of any of the deputies of 1682 to French bishoprics until $1693 .{ }^{76}$ Even so, the bishops flatly refused to retract their doctrines: when they eventually sent a conciliatory letter to Innocent XII in 1693, it deliberately apologised for the tone, rather than the content, of the articles. ${ }^{77}$

The bishops reacted in two distinct ways to the régale. The overwhelming majority raised little or no objection to its extension. One of Caulet's close associates, Étienne Le Camus of Grenoble, advised him to end his resistance on the basis that Caulet could not hope to prevent the crown's extension of the régale and should simply tolerate the inevitable, rather than risk a rift between the church and the monarchy. ${ }^{78}$ Other bishops agreed with Le Camus even if they inwardly found Louis's behaviour rather distasteful; when they explained their actions to the pope in 1682, they too suggested that it was necessary to compromise with the crown over the régale in order for peace to prevail and for the church to retain its otherwise privileged position in the realm. ${ }^{79}$ Le Camus was certainly discomfited by the crown's action and with the intellectual gymnastics that enabled him to accept it. Like other bishops, he resolved his disquiet by classifying the régale as a temporal, rather than a doctrinal or spiritual, matter and so unworthy of diehard opposition: 'The régale does not touch in any manner the rule of faith, or that of morals, which cannot be changed, or reformed . . . it is an affair of Discipline, . . . and can suffer this salutary softening. ${ }^{80}$ Yet Le Camus actually believed that the crown had illegitimately helped itself to a prize that was not in its power to award, and he privately expressed that worry while outwardly bowing to royal authority: 'I was never able to convince myself that the king had a universal right to the Régale attached to his crown and on all the bishoprics of his realm. ${ }^{81} \mathrm{He}$ had good reason for his discomfiture. One might expect a prelate like the former nuncio, Jerome de Grimaldi to object to the régale's extension, ${ }^{82}$ but even Charles-Maurice Le Tellier, the gallican archbishop of Reims, admitted that 'the régale . . . is a spiritual matter' and that any alterations to its current status should be made by the church. ${ }^{83}$ Yet that did not prevent him from attempting to bully Caulet, one of his provincial bishops, into submitting to the king. ${ }^{84}$ 
On the one hand, the régale could superficially be painted as a temporal affair that did not directly impinge on the episcopate's spiritual and disciplinary jurisdiction. Of course, if this argument was to justify its extension, the bishops also had, a priori, to accept the claim that the king was 'not subject to any ecclesiastical power in temporal matters' ${ }^{85}$ However, in reality, the régale was not simply a temporal matter, as Le Camus and Le Tellier knew, because the royal right to this resource had initially been freely presented by a general council of the church and from spiritual assets (benefices) that were naturally under the jurisdiction and protection of its prelates.$^{86}$ The bishops' position remained difficult to reconcile with the fact that they generally presented themselves as the watchful guardians of ecclesiastical prerogatives, were usually very quick to attack any threat to them and demonstrated unity of purpose and a strong sense of self-identity in doing so. Yet in this case the crown blatantly disobeyed a conciliar decree in order to extend its power over the church, and almost every French bishop, with 'wise condescension', simply accepted its behaviour. ${ }^{87}$ Only Pavillon and Caulet refused to do so because 'My character and several canons ... call me to conserve the rights and immunities ... that God has committed to my cares'; only they, in effect, acted in accordance with the bishops' century-long explanations of episcopal responsibility and jurisdiction: 'Bishops are the depositories of these rights . . . They must therefore employ the authority that they have received from Jesus Christ, to oppose the enterprises of secular persons, although sovereigns, on the rights of the Church. ${ }^{88}$

What does this anomaly in the episcopate's behaviour reveal about its relationship with the crown? Le Camus's remarks exhibit the general realisation within the episcopate that royal power was an increasingly formidable force to oppose and one that should be defied only for the gravest of reasons: 'I will give my goods and my life to content the king our master . . . when it will be a question of giving him marks of my obedience and my inviolable attachment to his person. ${ }^{89}$ Rather than indicating a shift in the episcopate's ideological position, however, this amply demonstrates the extent to which the crown had succeeded in enhancing its authority over the decades. Like the bishop of Grenoble, Le Tellier certainly realised that it would be 'imprudent' to oppose Louis's extension of the régale, and gradually moved to support the king's action on the basis that he would never subject 'his right to any judge, and is resolved to support his declaration and to employ his authority to enforce it' ${ }^{90}$ Correspondingly, 'besides the pleasure that I will have of profiting . . . by giving His Majesty a mark of my attachment and recognition, I find there the consolation of seeing that His Majesty will recognise . . that our maxims . . . are the rampart of the monarchy. ${ }^{91}$ A mix of sycophantic ambition and a desire to avoid incurring royal wrath were powerful incentives to indulge the monarch's behaviour. 
Yet, as Caulet warned, every time the secular power managed to exert its power in ecclesiastical territory, the dam separating church and state was weakened ever further. ${ }^{92}$ He and Pavillon thought in absolute terms of total and consistent resistance to these creeping encroachments; other later seventeenthcentury bishops thought realistically in terms of compromise. Certainly they all realised that the crown made a very formidable enemy, but neither Pavillon nor Caulet could permit himself to shirk his episcopal obligations and to give in to secular pressure. Perhaps Robin Briggs's conclusion that the pattern of episcopal appointments became far more routine and conventional in the 1670s has some significance here. Bishops educated in the Parisian seminaries and faculty of theology, and chosen partly on the basis of their likelihood to conform to the crown's will, would find it increasingly difficult to oppose a government with which they were so closely identified. ${ }^{93}$ Of course, many of their predecessors, like Du Perron or La Rochefoucauld, had been closely bound to the monarchy, but had been noted for independent thought and action. It would appear, therefore, that while the episcopate's ideals remained the same, its members were less willing to defy their government in defending them.

A second, and related, factor influencing the unwillingness of most bishops to displease their government over the régale may have been the cooling of the reform climate within the episcopate by the final quarter of the seventeenth century. It rose to its highest point in the middle decades, with bishops like La Rochefoucauld, Cospeau, Godeau, Harlay, Pavillon and Solminihac demonstrably willing to criticise the government and to refuse to obey its wishes when they felt it necessary for spiritual health. That attitude fitted neatly into the notion of the episcopal apostolate, and was characterised by willingness to actualise ideals of episcopal leadership and integrity. Principles were to be preserved and put into practice; even the threat of royal displeasure was not a sufficient reason to manipulate or abandon them. However, the suggestion that the final generation of prelates under Louis XIV's reign was less affected by this ideal should not be pushed too far, for many of them were not simply submissive yesmen who consistently abandoned their beliefs to avoid royal opprobrium. In the early eighteenth century, the crisis over Unigenitus would demonstrate that they could still put up a spirited resistance on issues that they considered to flout fundamental principles. When the crown sought a straightforward acceptance of the anti-Jansenist papal bull, the special assembly of prelates refused to do so and instead embarked on a painstaking evaluation of its doctrinal provisions in their role as judges of faith in a council representative of all French bishops. ${ }^{94}$

The bishops gained and lost in the régale wrangle and in the gallican crisis that produced the four articles. In failing to defend its own and the church's prerogatives, the episcopate failed to live up to the ideal that bishops had carefully developed and defended through previous decades and left the door wide 
open to further efforts by the secular authorities to dominate it and the ecclesiastical realm. At the same time, however, its formal confirmation of the régale allowed the episcopate to assert, once more, its right to lead the French church and to shape its future, even when the pope disapproved of its decisions. Equally significantly, the Articles of 1682 allowed the episcopate to stake its claim in general ecclesiastical government by formally confirming its conciliarist doctrine, confining the pope's authority over the universal church and denying papal infallibility. For this reason, the long-serving Gilbert de Choiseul could endorse them. His views had not altered over the decades of his episcopal career, for he had always rejected the doctrine of papal infallibility and supported conciliarism, and in 1682 he was still arguing that councils were superior to the pope in matters of faith, morals and discipline. ${ }^{95}$ Like Bossuet, Choiseul referred to the decrees of Constance to support his claim, ${ }^{96}$ and harked back to the conciliarist views expressed by Cardinal Lorraine over one hundred years before. ${ }^{97}$ With justification, both Bossuet and Choiseul placed themselves firmly within a long tradition of French episcopal gallicanism that had been sharply reinvigorated through the seventeenth century.

Episcopal gallicanism placed bishops at the centre of ecclesiastical life. They were perfectly aware that they could defend this ideal most successfully when they brought their collective weight into play, and they took every opportunity to do so, whether through the official Assembly or through specially convened meetings that published and legislated on their behalf. Only very rarely did any bishops use another device open to them: the provincial council. In the early years of the century, three councils were held, ${ }^{98}$ followed by Sourdis's Council of Bordeaux in 1624. But just three decades into the seventeenth century, the episcopate faltered in its implementation of Trent's decree on councils, for Bordeaux was the final provincial council held in seventeenth-century France. The councils did not halt because bishops were discouraged from holding them; actually, quite the contrary. Dony d'Attichy was just one of many prelates who told his fellows that their most effective defence against secular encroachments was united leadership, implemented through a system of regular provincial councils: 'Nothing being more certain, except that it is the sole source of the decadence of the episcopal order, which has occurred only since they have no longer been held.

Bishops habitually called for provincial councils from the early years of the century. In 1610, the Assembly of Clergy exhorted archbishops to convene provincial councils. ${ }^{100}$ The deputies of the 1614 Estates General proved more ambitious when they called for biennial provincial councils and just a year later, the Assembly reiterated this order, directing that provincial councils take place within the following six months. ${ }^{101} \mathrm{~A}$ decade later, it issued a letter to all 
bishops recommending that provincial councils be held for discipline and spiritual health. ${ }^{102}$ This particular instance of reforming zeal was produced in the enthusiasm surrounding Sourdis's warmly received council, but it too failed to show any practical results. Then, in 1645, the Assembly reiterated its earlier demands, actually troubling to back this up with letters patent encouraging archbishops to convoke councils. ${ }^{103}$ Five years later, that hope seemed about to be fulfilled when Harlay of Rouen began to organise a provincial council for his archdiocese, persevering with his arrangements even when the local parlement issued an arrêt forbidding the council to sit. ${ }^{104}$ Given the resistance of local authorities to any impingement of Tridentine rules on regional customs, it was not unexpected that the parlement should assume this position. The Assembly sternly rebuked it for its unwarranted 'enterprise', and encouraged Harlay to oppose its sabotage 'with vigour and courage'. ${ }^{105}$ A promise of royal support gave Harlay new energy and he continued with his plans until they were thwarted by the political upheaval of the Fronde and, ultimately, by his inopportune death in 1651. His disappointment did not deter bishops from continuing to present provincial councils as the best means of ensuring episcopal authority and dignity and of preserving discipline within the church: François Faure and Daniel de Cosnac both called for provincial councils in the mid-1660s, a move that would, Faure claimed, restore the church to its ancient brilliance. ${ }^{106}$

If French bishops envisaged provincial councils to be among the principal means by which their conception of episcopal leadership could be actualised, why were so few of them held in seventeenth-century France? That intriguing question has never been satisfactorily addressed by historians; beyond making the obvious observation that this aspect of Trent's programme was not really pursued after 1600, they have tended to concentrate on the features of Tridentine organisation which were actually implemented. ${ }^{107}$ Yet, given the theoretical link that bishops constructed between episcopal authority and provincial councils and the prolonged efforts by many of them to implement other Tridentine practices in their dioceses, it is instructive to ask why this particular angle of the Council's programme was not pursued to any significant degree. France was far, of course, from being the only branch of the church without many provincial councils; they were held only sporadically in the Spanish Netherlands and Ireland, for instance. ${ }^{108}$ They could be systematically established, however, as Borromean Milan and the Spanish archdiocese of Tarragona showed. ${ }^{109}$ This is not the place to indulge in general speculation about why provincial councils never grafted themselves onto the post-Tridentine church but, in the context of episcopal ideals, we can certainly make some pertinent observations for one of its major territories. The problem is especially fascinating when it is considered that provincial councils were held in late sixteenth-century France, amid the 
unrest caused by civil war. The evidence does not suggest that seventeenthcentury bishops considered the legislation produced by these to be definitive or sufficient, because they persisted in calling for further councils on the basis that they were essential for fostering unity, fraternity and supportive contact among bishops, as well as for the production of decrees on religious order. ${ }^{110}$

The furore surrounding the 1624 Bordeaux Council offers one reason why bishops did not act on these calls, for the fact that Rome proved so unaccommodating towards Sourdis's reform programme quite probably discouraged other bishops from following his lead. This debacle reflected the jostle for power that preoccupied the ecclesiastical hierarchy in the wake of Trent and, after Sourdis's unfortunate experience, other French bishops were likely to shy clear of such an uncertain means of asserting and exerting their authority. Yet while this disappointment was the most obvious reason for the bishops' failure to translate their stated intentions into actions, it was not the only one. Within their own ranks lay a second contributory factor: episcopal rivalry.

In practice, French bishops displayed a high level of rivalry in their attitude towards their neighbours, even though they successfully shrugged this off when faced with external threats from the papacy, lower clergy or the civil powers. Then they were generally able to present a united front, acting in concert to defend their collective rights. Within their own corps, however, their rivalry occasionally erupted into stormy conflicts, which fractured their unity as each sought to protect his jurisdiction and honour. This kind of clash was all too common through the century and cropped up for all sorts of reasons. Henri de Sponde took umbrage when a neighbouring bishop issued a marriage dispensation for a Huguenot resident in Pamiers, resulting in a spat that was resolved only when the offending prelate formally apologised to the aggrieved Sponde. ${ }^{111}$ Even Alain de Solminihac was not above criticising his neighbours: he complained bitterly to Vincent de Paul that they did not hesitate to poach his priests by offering them tempting benefices. ${ }^{112}$ This kind of friction could also manifest itself in full-blown quarrels between bishops and their archbishops. Once again, Solminihac's episcopate provides a vivid example of how jealously bishops guarded their jurisdictional territory: when Archbishop Hardivilliers reversed a suspension that Solminihac had issued on a curé, the bishop reacted angrily, protesting that this was a completely illegitimate slight on his authority. ${ }^{13}$ Some years before, Antoine de La Rochefoucauld of Angoulême had been equally unhappy with François de Sourdis when he modified a monitoire that the bishop had issued to unearth evidence against a murderer. Like Solminihac, La Rochefoucauld claimed that since his action had been entirely in harmony with canon law, the archbishop had no business interfering in his diocese. ${ }^{114}$ In both incidents, the archbishops were obliged to admit defeat, and the bishops could be satisfied that their jurisdictional powers and reputations remained intact. ${ }^{115}$ 
Yet these very public clashes illustrate the prevalence of diocesan territorialism or exclusivism within the episcopate; sentiments of corporate solidarity did not eradicate rivalry between bishops or their desire to protect their particular jurisdiction from encroachments by their colleagues.

This defensive antagonism spilled into the failure of provincial councils to become a common feature of French episcopal life during the seventeenth century. Cardinal Sourdis succeeded in inserting a clause into the decrees of Bordeaux that enabled him, as archbishop, to interpret its regulations personally until the next provincial council was held. He justified it by claiming that archbishops held the power to judge and interpret the laws made under their presidency. ${ }^{116}$ In fact, the measure was designed to enhance his control within the province, at the expense of its bishops and other clergy. Other archbishops were equally keen to ensure that their authority over bishops was maximised. When the bishops of Comminges, Alet, Pamiers, Conserans and Bazas issued a condemnation of Pirot's Apologie in 1658, the archbishop of the first four sees promptly overturned it and refused to allow its adoption in these dioceses. Archbishop Rebé feared the initiative taken by his suffragans: to him, their meeting and condemnation appeared perilously close to claiming the character and authority of a provincial council, which could legitimately meet and issue decrees only under his impetus and presidency. ${ }^{117}$

In actual fact, when one digs beneath the conscientious calls from members of the episcopate for provincial councils, it becomes apparent that only archbishops appeared to have any genuine enthusiasm for their actual convocation. When Rouen's parlement forbade the holding of a provincial council under Harlay in 1651, the archbishop found himself in the company of only one other prelate when he defiantly presented himself on the opening day of his meeting. ${ }^{118}$ While this may illustrate the gravity with which the bishops regarded the parlement's threat, it also demonstrates that the real desire to initiate regular councils lay with the archbishops, rather than with the diocesan bishops. In practice, therefore, it appears that the episcopate's wish for provincial councils was one which, with the exception of archbishops like Harlay, was largely formal. The vast majority of bishops willingly convoked diocesan synods where they could hope that their jurisdiction and wishes would prevail. But they were unlikely actively to favour provincial councils in which the presiding archprelate would perhaps try to impose his autocratic authority on them.

Stifled by the ambivalent and downright contradictory views within the episcopate and by antagonism from secular authorities, provincial councils never stood much chance of becoming an ordinary part of the ecclesiastical framework: they were simply headaches to organise and implement, and more trouble in practice than they were theoretically worth. Indeed, their absence undoubtedly contributed to the progressive strengthening of the Assembly of 
Clergy, which, in filling the vacuum left by the demise of councils, gradually came to be seen as the representative and authoritative voice of the clergy, and particularly of the episcopate. Still, the persistent calls by the episcopate for provincial councils illustrates that bishops were absolutely aware of the secular realm's ever-increasing tendency to encroach on the affairs of the sacred and, specifically, to appropriate their jurisdiction. But not even their representatives in the Assemblies could halt that distasteful progression. Would provincial councils have eradicated it, as so many bishops alleged? If systematically held, they would have united the bishops at regional level, perhaps enabling them to present a collective front against the attacks of local officials and parlements. However, it is highly unlikely that conciliar legislation, with no confirmation in secular law, would have deterred these determined attempts to dominate episcopal rule. Episcopal gallicanism and political gallicanism differed dramatically in the significance that they ascribed to the jurisdictional role of bishops. This gulf meant that the bishops spent most of the seventeenth century fighting the creeping menace to their authority from the secular realm. Naturally, the sacred and secular powers could often work in tandem and to the bishops' benefit, an advantage that they were not slow to seek and exploit. Yet that collusion worked only when the government wished it, and it meant that, almost invariably, the episcopate was obliged to surrender and to compromise its ideals in order to maintain its uneasy alliance with the temporal authority in France.

Notes

1 The best summary is found in Robin Briggs, Communities of Belief. Cultural and Social Tensions in Early Modern France (Oxford 1995), pp. 181-234. See also Mettam, Power, pp. 243-56.

2 Pierre Dupuy, Traitéz des droits et libertéz de l'église gallicane (n.p. 1639); Pierre Dupuy, Preuves des libertéz de l'église gallicane (n.p. 1639).

3 Bergin, Episcopate, pp. 460-541.

4 Ibid., pp. 322-32, 598, 691.

5 This was a refrain in the writings of reformers. For example: Jean-Pierre Camus, Homelies panegyriques de Sainct Charles Borromee, cardinal du titre de Sainct Praxede, archevesque de Milan (Paris 1623), pp. 116-18; Camus, Hiérarque, pp. 158-9, 189, 225-30, 370-1, 667-8; Godeau, Lettres, p. 286, letter to an unnamed bishop, 23 July 1646; ibid., pp. 318-19, letter to Abbé de Thomassin (n.d.).

6 Bergin, Episcopate, pp. 469-711; Kettering, Patrons, pp. 124-5; Mettam, Power, pp. 247-8.

7 Samuel Martineau took on a similar role in the region: René Toujas, 'Les Démêlés de Samuel Martineau, évêque de Bazas (1646-1667) avec le parlement de Bordeaux,'Actes du 104 Congrès National des Sociétés Savantes, ii (Paris 1981), pp. 51-62.

8 Hoffman, Church, pp. 86-97, 133-4; Luria, Territories, pp. 53-105; Peyrous, Réforme, i, pp. 120-200.

9 Peter Burke, The Fabrication of Louis XIV (New Haven and London 1992); Mettam, Power, pp. 13-44.

10 William Beik, Absolutism and Society in Seventeenth-Century France. State Power and Provincial Aristocracy in Languedoc (Cambridge 1985); Richard Bonney, The Limits of Absolutism in Seventeenth-Century France (Aldershot and Brookfield, Vermont 1995); Briggs, Early Modern France, pp. 73-159; Ragnhild Hatton (ed.), Louis XIV and Absolutism, (London and Basingstoke 1976). 
11 For full discussion of the clergy's financial history see Blet, Clergé . . monarchie, i, pp. 374 96; ibid., ii, pp. 256-87; Blet, Assemblées, pp. 3-33, 84 -90; Claude Michaud, L'église et l'argent sous l'ancien régime. Les receveurs généraux du clergé de France aux xvi--xvii siècles (Paris 1991).

12 Bossuet, Oeuvres complètes, xxiv, pp. 1-259.

13 Du Pin, Histoire, iii, p. 533.

14 These cases are discussed in detail in Pierre Blet, 'L'Article du tiers aux états généraux de 1614', Revue d'Histoire Moderne et Contemporaine, 2 (1955), 81-106; Blet, Clergé . . . monarchie, i, pp. 335-69; Bergin, La Rochefoucauld, pp. 69-73; J. Michael Hayden, France and the Estates General of 1614 (Cambridge 1973), pp. 131-48.

15 Procès-verbaux, ii, p. 21.

16 Leonor d'Etampes, Declaration de messieurs les cardinaux, archevesques, evesques, et autres ecclesiastiques deputez en l'assemblée generale du clerge de France, tenue à Paris. Touchant certains libelles faicts contre le roy et son estat (Paris 1626).

17 AN, G8* 643b, fos 459-60.

18 This is discussed at a later point in this chapter.

19 Jean-François-Paul Gondi de Retz, Oeuvres de Retz, ed. J. Gourdault, R. de Chantelauze and C. Cochin, 11 vols (Paris 1870-1920), vi, p. 28.

20 Godeau, Remonstrance, p. 7: 'Les Evesques ne faisant qu'un Evesque, l'injure de l'un est l'injure de tous, ou plûstost de toute l'Eglise.'

21 See AN, G8* 653, 14 November 1656, for the Assembly's demand that Retz be judged 'following the law and the canonical constitutions, the immunities and privileges of bishops and of the Gallican Church'; Blet, Clergé . . . monarchie, ii, pp. 126, 232-4.

22 Martin, Réforme, pp. 303-43.

23 François de La Rochefoucauld, Raisons pour le désaveu fait par les évesques de ce roiaume d'un livret publié avec ce tiltre Jugement des cardinaux archévesques et autres qui se sont trouvés en l'assemblée générale du clergé de ce roiaume sur quelques libelles diffamatoires (Paris 1626), p. 197; Blet, Clergé ... monarchie, i, pp. 125-33; Martin, Réforme, pp. 377-86.

24 Recueil des actes, vi, col. 165.

25 François Faure, Remonstrance du clergé de France faite au roy (Paris 1666), p. 10; François de La Rochefoucauld, De l'estat ecclésiastique (Lyon 1597), pp. 36-7; La Rochefoucauld, Raisons, p. 286, citing Mark 12:17.

26 Ordonnances, advertissemens, et instructions aux recteurs, et autres ecclesiastiques du diocese de Pamiers (Toulouse 1630), p. 15; Ordonnances ecclesiastiques et statutz synaudaux faictz par monseigneur l'archevesque de Bourges patriarche primat d'Aquitaine, pour le reglement et police du clergé de son diocese (Bourges 1608), 31-2; Ordonnances et constitutions synodales, decrets et réglements donnez au diocèse de Bourdeaux par feu de bonne mémoire monseigneur le cardinal de Sourdis. Reveus, confirmés et augmentés par très-illustre et très-révérend père en Dieu Messire Henri Descoubleau de Sourdis, archévesque de Bourdeaux, et primat d'Aquitaine (Bordeaux 1639), p. 352.

27 Recueil des actes, i, cols 357-60.

28 La Rochefoucauld, Estat, p. 58.

29 Blet, Clergé . . monarchie, ii, p. 292.

30 André-Hercule de Fleury, Oeuvres de l'abbé Fleury (Paris 1884), p. 430.

31 Peyrous, Réforme, i, p. 686. Sourdis was equally incensed when his chapter appealed to the parlement to resolve an internal dispute (in which he was not directly involved): Letter to the Dean and Canons of the Metropolitan Church of Saint André (n.p. 1642).

32 Morestel, Guidon, p. 319. Morestel justified this intervention by arguing that if bishops did not fulfil their ecclesiastical duties correctly, then the parlement was obliged to ensure that curés were protected from new abuses: ibid., unpaginated.

33 François Hallier, De la iurisdiction ecclésiastique au royaume de France (n.p. 1651), pp. 40-1, 81-2.

34 Cahier des remonstrances du clergé de France, presenté au roy par l'assemblée generale, tenue à Paris és années 1635 et 1636. Avec les responses faites par sa majeste sur lesdites remonstrances (n.p. n.d.); Procès-verbaux, iv, p. 263; ibid., v, pp. 180-1. 
35 Bertrand Deschaux, for example, complained that the governor of Bayonne (Gramant) refused to allow him into his episcopal town, thereby symbolically rejecting the newly consecrated bishop's authority and mocking his episcopal 'honour': 'Documents inédits', ed. Philippe Tamizey de Larroque, Revue de Gascogne, 20 (1879), 405, Deschaux to Phélypeaux, 22 July 1611.

36 Ordonnances... Bourdeaux, pp. 350-61.

37 Cahier, pp. 3, 9: 'Ils suspendent l'execution des Ordonnances . . ., renversent les Iugemens Ecclésiastiques, ils prennent connoissance de toutes les causes personnelles des Ecclésiastiques . . qui sont enterprises très-grandes contre la Iurisdiction de l'Église.'

38 Philippe Cospeau, Remonstrance du clergé de France, faicte au roy le 18. iuillet (Paris 1617), p. 20.

39 Bourlon, Remonstrance, pp. 5-9.

40 Solminihac, Lettres, p. 426, Solminihac to Chansarel, 27 November 1650: 'Quand il faudroit y perdre la vie, je l'exposerois volontiers pour en avoir raison et conserver la juridiction de l'Église en son entier.'

41 Godeau, Lettres, p. 317, letter to Thomassin (n.d.).

42 Faure, Remonstrance, p. 9, 31.

43 La Rochefoucauld, Estat, p. 612.

44 The parlement had attempted to regulate the duration of seminary training and the pensions of clerics. Sol, Solminihac, p. 366, Solminihac to Du Ferrier (vicar-general of Albi) (n.d.): 'J'aurais volontiers quitté tous les procès pour l'aversion qui j'y ai, mais j'y suis forcé par le serment que j'ay fait de conserver les droits de mon Église et par mon obligation de veiller sur la conduite des âmes dont je suis chargé.' See also Solminihac, Lettres, p. 553, Solminihac to d'Estrades (bishop of Condom), 20 December 1653.

45 Ibid., p. 553, Solminihac to d'Estrades, 20 December 1653; Recueil des actes, vi, cols 165-7.

46 Godeau, Histoire, iii, p. 706; Godeau, Remonstrance, p. 8.

47 He was appointed president in September 1622 and formally retired in 1624 or 1625: Bergin, La Rochefoucauld, pp. 62-4.

48 La Rochefoucauld, Estat, pp. 331-2.

49 Camus, Homélies des États Généraux (1614-1615), ed. Jean Descrains (Geneva 1970), p. 350.

50 Bergin, La Rochefoucauld, p. 65.

51 Lettres, p. 287, letter to an unnamed bishop, 23 July 1646; Recueil des actes, vi, cols 165-7.

52 Godeau, Lettres, p. 286, letter to an unnamed bishop, 23 July 1646; ibid., p. 319, letter to Thomassin (n.d.).

53 Hallier, Iurisdiction, p. 6.

54 Provincial councils are discussed at a later point in this chapter.

55 Recueil des actes, vi, cols 169-70.

56 The portion congrue was the portion of revenue (or salary) paid by the tithe owner to the resident curé of a parish. Under the ancien régime, it affected approximately one third of all French parish priests: Tackett, Priest, p. 120; Blet, Clergé . . monarchie, ii, p. 326.

57 AN, X1a 8394, 12 December 1664.

58 AN, G8*653, 19 December; Faure, Remonstrance, pp. 8-10.

59 Procès-verbaux, iv, pp. 196-206; Faure, Remonstrance, p. 32.

60 AN, G8*658a, 18 November.

61 AN, G8* 653, 19 December; Blet, Clergé . . monarchie, ii, p. 337.

62 Recueil, ed. Isambert, xx, p. 243.

63 Ibid., p. 255: 'Voulons que les archevêques [et] évêques . . . soient maintenus dans tous les droits . . . et avantages, dont ils ont joui ou dû jouir jusqu'à présent.'

64 Ibid., p. 253: 'service divin, réparations des églises, achats d'ornemens, subsistance des curés . . . corrections des moeurs des personnes ecclésiastiques, et toutes autres choses concernant la discipline ecclésiastique...'

65 Ibid., p. 252: 'la réparation du scandale, et trouble de l'ordre et tranquilité publique, et contravention aux ordonnances, qui la publication [d'un] doctrine aura pu causer'.

66 Blet, Assemblées, pp. 128-31. 
67 Documents relatifs aux rapports du clergé avec la royauté de 1682 à 1705, ed. Léon Mention (Paris 1893), pp. 23-4.

68 AN, G8* 664A, pp. 571-2, 943-50.

69 The dioceses of Languedoc, Guyenne, Provence and Dauphiné were all customarily exempt from the régale: Decrees, ed. Tanner, i, pp. 309-31.

70 Pavillon died in 1677, followed by Caulet three years later: Bergin, Episcopate, pp. 592, 680.

71 Gaillard, Choart, pp. 253-65; Vidal, Caulet, pp. 449-555.

72 Blet, Assemblées, pp. 348-50, 360-2; Martimort, Bossuet, pp. 443-79.

73 Gérin, Recherches, p. 68; Le Maistre, Pape, ii.

74 Orcibal, Louis, p. 7; Mettam, Power, p. 251.

75 In April 1682 and August 1692 respectively. The bishops refused to retract their confirmation: Documents, ed. Mention, pp. 37-43, 48-63; Orcibal, Louis, p. 9.

76 Ludwig von Pastor, History of the Popes, 40 vols (London 1891-1953), xxxii, p. 304.

77 Blet, Assemblées, p. 570.

78 L'Extension de la régale à tous les évêchés de France, ed. Marc Dubruel (Toulouse 1911), pp. 289, Le Camus to Caulet, 21 August 1679.

79 Documents, ed. Mention, pp. 8-9, 12, 20-1.

80 Ibid., pp. 10-11: 'La Régale ne touche en aucune manière la règle de la Foi, ni cele des moeurs, qui ne peut ni changer, ni être réformée . . . c'est une affaire de Discipline, . . . et peut souffrir cet adoucissement salutaire.' See also Extension, ed. Dubruel, p. 28, Le Camus to Caulet, 21 August 1679: 'Il ne s'agit ici que d'un droit sur le temporel de nos églises dont nous devons être moins jaloux incomparablement que s'il s'agissait du spirituel.'

81 Gérin, Recherches, p. 150, Le Camus to Le Tellier, 30 May 1681: 'Je n'ai jamais pu me convaincre que le Roi eût un droit de Régale universelle attaché à sa couronne et sur tous les évêches de son royaume.'

82 Ibid., p. 191, Grimaldi to Michel Le Tellier (chancellor), 12 August 1681.

83 Ibid., p. 42, Memoir (1680).

84 Orcibal, Louis, p. 5.

85 Du Pin, Histoire, iii, p. 533.

86 Gérin, Recherches, p. 159, Le Camus to Michel Le Tellier, 30 May 1681.

87 Documents, ed. Mention, p. 16.

88 Extension, ed. Dubruel, p. 32, Caulet to Le Camus, 19 September 1679: 'Mon caractère et plusieurs canons . . . m’imposent de conserver les droits et les immunités . . que Dieu a commise à mes soin.'; ibid., p. 36, Caulet to Le Camus, 23 July 1680; Gaillard, Choart, pp. 252-3, Pavillon to the Assembly, 8 July 1675: 'Les évêques sont les dépositaires de ces droits ... Ils doivent donc employer l'autorite qu'ils ont reçue de Jésus-Christ, pour s'opposer aux enterprises des personnes séculieres, quoique souveraines, sur les droits de l'Eglise.'

89 Gérin, Recherches, p. 152, Le Camus to Michel Le Tellier, 30 May 1681: 'Je donnerais mes biens et ma vie pour contenter le Roi notre maître . . . quand il s'agira de lui donner des marques de mon obéissance et de mon attachement inviolable à sa personne.'

90 Ibid., p. 125: 'soumettre son droit à aucun juge, et est dans la résolution de soutenir sa déclaration et d'employer son autorité pour la faire valour'.

91 Ibid., pp. 141-2, Le Tellier to Louvois, 29 March 1681: 'Outre le plaisir que j'aurai de profiter . . . pour donner à Sa Majesté une marque de mon attachement et de ma reconnaissance, j'y trouve une consolation, qui est celle de voir que Sa Majesté connaîtra . . que nos maximes . . . sont le rempart de la royauté.'

92 Extension, ed. Dubruel, p. 32, Caulet to Le Camus, 19 September 1679.

93 Briggs, Communities, p. 209.

94 Blet, Louis XIV et le saint siège, pp. 429-80, 577-604; Lucien Ceyssens, L'Unigenitus et sa preparation à Rome (Rome 1984).

95 AN, G8* 664A, p. 759: 'Le concile peut réformer les décrets du Pape.'

96 Ibid., pp. 846-7; Bossuet, Oeuvres oratoires, vi, pp. 86-138. 
97 AN, G8*664A, p. 857.

98 Narbonne (1609), Sens (1612) and Aix (1612): Martin, Réforme, p. 164n.

99 Recueil des actes, vi, col. 163: 'N'y aïant rien de plus certain, sinon que c'est la seule source de la décadence de l'ordre Episcopal, qui n'est déchû que depuis qu'on a cessé d'en tenir.'

100 Procès-verbaux, i, pp. 4, 16.

101 Ibid., pp. 141, 242.

102 Lettre de messieurs les archévesques, touchant la convocation des conciles provinciaux: par l'advis de l'assemblée générale du clergé de France, tenuë à Paris (Paris 1625), pp. 7-9.

103 Blet, Clergé . . monarchie, ii, p. 53.

104 AN, G8*652, 23 November; Blet, Clergé . . monarchie, ii, p. 54.

105 AN, G8* 652, 10 January. This suspicion of provincial councils was not confined to France, but was also evident in Spain, where the secular authorities insisted that royal representatives be present at every meeting and that decrees be approved by the Royal Council. If Harlay's council had gone ahead, it is not inconceivable that the parlement would have insisted on its being represented there: Henry Kamen, The Phoenix and the Flame. Catalonia and the CounterReformation (New Haven and London 1993), pp. 56-62; Wright, 'Ideal', p. 190.

106 Faure, Remonstrance, p. 35.

107 See, for example, the standard works on French reform: Delumeau, Catholicism; Taveneaux, Catholicisme.

108 Alison Forrestal, Catholic Synods in Ireland, 1600-1690 (Dublin 1998), pp. 195-6; Harline and Put, Tale, pp. 110-32.

109 Although Borromeo presided over regular provincial councils in Milan the practice died out under his successors: Prodi, 'Borromée'. Tarragona was the only Spanish province to institute frequent provincial councils. Thirty-six were held between 1565 and 1757, at approximately five-year intervals: Kamen, Phoenix, pp. 77-9.

110 Borromeo had similar aims for his provincial councils: Prodi, 'Borromée', 388.

111 Cinq visites, ed. Contrasty, p. 132; Vidal, Sponde, p. 73.

112 Solminihac, Lettres, p. 298, Solminihac to de Paul, 25 May 1650.

113 Ibid., p. 332, Solminihac to unnamed correspondent, 10 February 1646.

114 Ravenez, Sourdis, pp. 496-7.

115 Richelieu also criticised the tendency of archbishops to appoint candidates to benefices by overruling the decisions of diocesan bishops to reject them: Armand-Jean du Plessis de Richelieu, Testament politique de Richelieu, ed. Françoise Hildesheimer (Paris 1995), p. 132.

116 'Documents', ed. Ducaunnes-Duval, 475. Rome suppressed the rule, arguing that an archbishop's authority did not stretch this far: Gouyon, Introduction, p. 240; Broutin, 'Concile', 408 .

117 Dubruel, 'Hiérarchie' (1919), 337.

118 Bishop Gilles Boutault of Evreux: AN, G8* 652, 16 and 27 January. 


\section{6 \\ Manuals and hagiography: mirrors of French ideals?}

Didactic literature for bishops was hardly a new phenomenon in the seventeenth century; indeed its pedigree extends all the way back to the early church. Nor was it an exclusively French tradition. During the late sixteenth century numerous efforts were made outside France to produce texts which would be sources of both spiritual nourishment and practical administrative guidance for prelates. ${ }^{1}$ Within France itself, however, no work of this kind was produced during that period, probably because the civil wars discouraged it in favour of straightforwardly robust polemics. To compensate, Latin and vernacular editions of nonFrench episcopal literature were published to serve the needs of the French episcopate, a practice continued in the following century, with French editions of Possevin's discourse on Borromeo, Giussano's history of Borromeo and an abridged life of the archbishop of Milan based on existing literature. ${ }^{2}$ Then, as the French church recovered in the first decades of the seventeenth century, French writers began to compose works of their own, specifically designed to serve their bishops. This was a feature of a wider development within the reform movement, whereby other clerical groups, like curés, were offered detailed written advice on the nature and functions of their office. ${ }^{3}$

The preceding chapters have used evidence from many of the treatises and other works, composed in France through the seventeenth century, which dealt with the duties and responsibilities incumbent upon bishops: works which were designed, therefore, and written by both prelates and non-episcopal clergy, to function as guidebooks for bishops. However, the abundance of texts means that they repay closer exploration on several fronts, for they teach much about the germination and dissemination of episcopal ideals. First, how did their detailed construction of episcopacy compare with those described in the previous chapters? The answer to this question is as relevant for the pastoral angle of episcopacy as it is for the jurisdictional and theological, and is directly related to the chapter's second major objective of tracking the emergence of the ideal episcopal pastorate. Here, the extensive evidence provided by published texts 
is supplemented by the private writings and correspondence of bishops themselves and of those other individuals who played powerful roles in influencing the bishops' conception of their pastorate. These sources are necessarily somewhat selective but are sufficiently varied in both authorship and chronology to enable us to discern how far bishops and their advisors, in practice, could, and actually did, share the administrative, pastoral and spiritual ideals of prelacy presented within published works.

These publications on episcopacy can be crudely arranged under two headings: general guides that treated the character of episcopacy and the duties associated with it, and hagiographic works. Of course, hagiographic works always contained elements of the first literary category, in that the lives of particular bishops were presented as the models or examples for their ecclesiastical descendants. They were composed using a mixture of documentary and oral sources and were based on historical facts that were then given a distinctly hagiographic hue. Étienne Molinier, who published a biography of Barthélemy de Donadieu, bishop of Comminges, shortly after the prelate's death in 1637, observed that he did not intend his composition to be a panegyric or oratory: instead he wrote as a 'faithful historian' who was content to propose 'the fact in its truth, and purity'. ${ }^{4}$ His work, however, was not simply a factual account of the bishop's life, but rather used facts to exalt Donadieu's character and actions within an idealised framework.

With the return of stability to the French church, writers were free to produce theological works which ranged wider than defences against protestantism, a fact confirmed by the large numbers of publications that flooded the market from the 1620s onwards. Foreign works relating to episcopacy continued to be printed in France but were now progressively accompanied by native French productions. Some of these texts were composed by bishops themselves, though the majority were written by non-episcopal clergy: of the thirty-eight such works published between 1600 and 1670, eleven were written by French bishops while the remainder were by other members of the French clergy. It is significant that bishops themselves wrote both didactic and hagiographic texts: three manuals to guide bishops in their vocation and eight hagiographic treatises. Non-episcopal clergy, in contrast, tended to focus almost exclusively on hagiography: twenty-three of their works belonged to this category. The bishops' preference for instructional publications perhaps points to their conviction that this was a type of work immediately necessary to their own, and their confreres', vocational needs. That in turn perhaps explains why non-episcopal clergy may have felt less qualified to produce this type of very specialised text, and so concentrated on the generally more straightforward and traditional hagiography.

Manuals of instruction tended to follow a distinct structural pattern, although they varied in length from reasonably compact volumes to extended 
treatises like those of Bishop Camus. After an introductory preface in which the author revealed his intention to provide a source of information and guidance for bishops, they first treated the origin and meaning of the episcopal office, particularly pointing to its august lineage and illustrious roots in the apostolic church. They usually attended to the formation of the bishop's vocation and to his consecration as well as to the dignity of his office and then progressed to examine his responsibilities under the broad headings of administration, teaching and episcopal perfection. This final category led to discussion of episcopal sanctity and the proper means by which to cultivate personal virtue. This type of text invariably cited ancient and contemporary bishops as examples for their readers to learn from and to imitate in their own lives.

Hagiographic compositions, on the other hand, chose one or several bishops as their principal subject and painted a picture of the ideal prelate from their biographies, elaborating on their saintly qualities and industrious lives. Most were, moreover, written with the aim of securing the beatification of their worthy subject, if this had not already taken place, and included direct pleas to the papacy to achieve this. Again, an introductory preface preceded the main body of text, frequently dedicated to a contemporary French bishop who was usually the author's patron. Often these volumes were produced by former servants or assistants of the bishop who was under their spotlight: one such was produced by Jean-Baptiste Noulleau on Étienne de Villazel. ${ }^{5}$ The format of the works was, without exception, conventional, beginning with a description of the life of the subject and proceeding from his birth, through his call to the episcopate, his consecration and work as bishop, to his death and the miracles associated with it. They usually concluded with a litany of prayers to the saintly bishop and recommendations that he be beatified. Included throughout were lengthy discussions of the bishop's virtues with numerous examples of how these had been put into practice. Each work was designed, therefore, to demonstrate that its candidate satisfied the requirements for official sanctification: doctrinal purity, heroic virtue and miraculous intercessions after death. ${ }^{6}$ Generally, however, the bishops were presented principally as virtuous models of episcopal excellence, rather than as workers of miraculous wonders, a balance that highlights the didactic character of these texts.

Finally, hagiography can be broadly subdivided into compositions which presented ancient bishops and those which concentrated on bishops of the sixteenth and seventeenth centuries. Works, however, which had seventeenthcentury French bishops as their subject were far fewer in number than those dealing with the ancient church fathers and recently deceased non-French bishops, like Charles Borromeo. In addition, we must take account of the growing vogue for diocesan histories, which generally contained succinct biographies of successive bishops, ancient and contemporary. ${ }^{7}$ These were not composed as 
didactic works but principally as historical records. Yet their descriptions of particular bishops at times assumed a distinctly hagiographic tone and, if only for this reason, they will on occasion be cited in the course of this chapter.

One of the most noticeable features of seventeenth-century literature on the office of bishop is its marked tendency to reflect the dominant features of the episcopal ideology then emerging in the French church. From the early 1620s, when publications began to appear, they stressed the dignity, perfection and obligations of the episcopal state, in a manner closely resembling the ideas of Bérulle and his successors. Perhaps surprisingly for a Jesuit, though it may have been because he was a close associate of reform-minded prelates like Cardinal de La Rochefoucauld and Octave de Bellegarde of Sens, ${ }^{8}$ Étienne Binet declared grandly in 1633 that neither heavenly or earthly eloquence could 'worthily represent the dignity of those who hold the first rank in the Hierarchy'. He proceeded then to describe the ecclesiastical hierarchy in straightforwardly Dionysian terms: bishops were 'vicars of God . . . who burn with love of God, ... the image of the living God, his lieutenant under heaven . . . Can one conceive anything more eminent?'9 Around the same date, Nicolas Lescalopier, a royal prédicateur, also emphasised the perfection of the episcopal state and the function of bishops to draw others to perfection, through their governmental authority and powers of order: 'What power has a father on his children, and what respect and obedience the children owe their father; whatever condition men might be, they are the children of bishops. ${ }^{10}$ The writing of the Oratorian spiritualist and theologian Jean-Baptiste Noulleau on episcopacy was also filled with the ideas propagated by Bérulle, Eudes, Olier and other leading reformers. It is quite consistent, consequently, to find Noulleau presenting bishops as 'surveyors' or supervisors over all those below them in the church's hierarchy. ${ }^{11}$ Their office was one of perfection, requiring that they be irreproachable in their own lives so that they might draw others to perfection by acting as a light in darkness. Too many bishops of the present century, Noulleau confessed, palpably failed to live up this calling because they were infected with the 'spirit of the world'. ${ }^{2}$

The adoption of the reformers' conception of episcopacy is even more marked in the compositions published by bishops themselves. Bishop Etampes's Advis flamboyantly likened diocesan bishops to the moon, stars and sun, since it was their role to dissipate the shadows of ignorance from men's minds. Bishops formed the most eminent rank within the church, were the mediators between God and man, and were the leaders and fathers of the faithful. ${ }^{13}$ That elevated rank meant that they must live lives of absolute sanctity and illuminate their flock by example and words. ${ }^{14}$ The writings of Jean-Pierre Camus echoed these views precisely. He published a detailed manual for bishops, designed to function as a 
mirror in which his fellow 'vicars and ambassadors of God' could contemplate themselves and 'note what good you have so as to render thanks for it to the Father of lights, . . . and as to what you lack, that you will try to attain the pure gold that the Angel in the Apocalypse counsels a bishop to buy in order to render himself rich for eternity'. ${ }^{15}$ Camus's prelates were sentinels and superintendents who gave 'order to all' regarding 'God's service and the people's health' ${ }^{16}$

In fact, Camus was among those who actually used Bérulle's striking title, grand prêtre, to describe the good bishop who possessed all the qualities of an ordinary parish priest, but in greater abundance and intensity. ${ }^{17}$ In part, the title referred to the jurisdiction that a bishop enjoyed over his priests and to his ability to celebrate the eucharist. ${ }^{18}$ Yet, beyond these, the bishop also held the greatest ability to reveal or mediate God's truths to his people through teaching and through the sacraments of confirmation and ordination: 'The divine man, filled with sacred knowledge' purged sins, enlightened souls and drew them to virtue and ultimately union with God. ${ }^{19}$ His pre-eminence bound him to fulfil his role of government and ambassadorship consistently and wholeheartedly, for if he did not he would be "like the Sun which warms all things without having any degree of heat in itself' ${ }^{20}$ Bishops were leaders, Camus noted, whom those below them in ecclesiastical rank must obey, but this power brought obligations of personal sanctity, as befitted those closest to God. ${ }^{2}$

Etampes and Camus composed their writings during the decades when Bérulle's ideas on the priesthood and episcopacy were in the ascendant and when prominent figures like Condren, Saint-Cyran and de Paul were promoting them through their writings, correspondence and involvement in clerical reform. The opinions expressed by both bishops demonstrate yet again the penetration of the reform school's understanding of episcopacy into the episcopate itself. Indeed, Camus was certainly not the only bishop explicitly to adopt the crucial Bérullian title of grand prêtre. In 1649 and 1656, five southwestern bishops met in Mercuès to discuss the character and purpose of their episcopal vocation and the ways in which these could inform their behaviour most beneficially. The conferences' participants were Caulet, Pavillon, Solminihac, Brandon of Périgueux and Sévin of Sarlat. All five were conscientious overseers of their dioceses. Their dedication to their responsibilities is perfectly clear from the records which they made of their meetings: as sources, these sessions demonstrate the breadth and depth of reflection in which it was possible for bishops to engage during a series of intensive meetings, and their attention to specific aspects of episcopal spirituality and pastoral care reveals their primary reform concerns and interests. Furthermore, the results of these discussions provide an illuminating case study of just what spiritual views prelates could, and were willing to, adopt as principles for their lives. ${ }^{22}$ Significantly, after promising to celebrate the eucharist frequently, the Mercuès 
bishops used the embracing term grand prêtre to describe its centrality to the episcopal life. In the eucharistic celebration, the bishop honoured God, appeased his 'ire', and thanked him for the blessings he had granted his people. By bringing the sacrifice of Christ into relief, however, the mass also became an excellent preparation for death, and was more applicable to bishops than to any other members of the church, 'because of the particular alliance that we have contracted with our Lord'. Like Bérulle and Olier, the conferences encouraged bishops to identify with Christ, for 'we are like the victim that must be immolated for all the people of our dioceses, and we will approach with this spirit of victim. ${ }^{23}$ More broadly, their entire lives, every thought and action, should be informed by love of the cross, so that they would sacrifice their own lives to God; they would 'suffer all for God's glory and the health of others'. ${ }^{24}$

The vision of episcopal sacrifice, imitation of Christ and union with the divine that these five bishops embraced under the banner of grand prêtre was a classic formulation of the Bérullian school's theology. The school's influence on bishops' understanding of their office obviously began quite early in the century and tended to progress in tandem with the reformers' refinement of their own views of episcopacy. Most apparently, the prolific work of Antoine Godeau tracks this process. He shared the opinion that bishops held first rank within the ecclesiastical hierarchy, with authority over those inferior in grade. He too conceived a direct connection between that sublime status and the lives of bishops: the episcopate was 'the most holy dignity on earth, . . . the participation in all the grandeur and all the power of the Son of God', and its incumbents must be 'more elevated above the people as much by their virtues as by their character' ${ }^{25}$ But Godeau belonged to a later generation of bishops than Camus and Etampes, born in 1584 and 1589 respectively. He was born in 1605 and was consecrated bishop in 1636, by which time both Camus and Etampes had been bishops for many years. ${ }^{26}$ So he entered the episcopate at the point when the reformers' stress on the dignity and authority of bishops was being voiced by members of the episcopate itself as well as by apologists like Saint-Cyran, Hallier and Le Maistre. As a result, his writings on episcopacy, produced from the early 1650s endorsed these conceptions but were also profoundly shaped by the sophisticated exposition of episcopacy defined by Jean-Jacques Olier. ${ }^{27}$

In 1642, Camus had argued that there appeared to be no reason to deny that episcopacy possessed a unique character of its own, on the basis of its powers of perfection and jurisdiction, even though the office was one element of the sacrament of order. ${ }^{28}$ But, progressing further than Camus, Godeau followed Olier's conception of episcopacy openly and completely. In 1657, he published a life of Charles Borromeo for his own instruction and that of other prelates. ${ }^{29}$ Although he used material from earlier histories, Godeau added his own opinions and emphases throughout. According to him, God had given Borromeo 
to the church as an example to bishops at a time when the re-establishment of discipline was vital. To achieve this, Borromeo held a plenitude of episcopal spirit to diffuse throughout his province. Like Olier, Godeau therefore identified a specifically episcopal grace by which bishops drew their charges towards perfection. This vivifying grace animated the actions and words of bishops as they functioned as pastors and governors in their dioceses. It was spread through the zealous actions of purification, illumination and perfection, each evident in conscientious administration, a lack of selfishness, a 'pure and ardent love of the Church', 'love of their flock' and love of God..$^{30}$

Before Godeau's exposition, no other bishop had expressed the distinction of order between bishops and priests in a manner so close to that which Olier submitted to the Assembly and sent to all French bishops in 1651. Godeau reiterated this understanding of episcopal grace when he wrote eight years later in his eulogy of the late Jean-Baptiste Gault, bishop of Marseille: 'The highest degree of grace on earth is that of the episcopate; and Father Gault was entirely penetrated with it.' This grace was manifested and imparted through Gault's devotion to preaching, works of charity and poverty and, in general, the imitation of his master, Jesus Christ. ${ }^{31}$ Godeau's praise of Nicolas Pavillon also endorsed this view. He claimed that the bishop of Alet possessed a plenitude of episcopal spirit, granted by Jesus Christ, which enabled him to fulfil his functions as bishop with mildness, zeal, wisdom, prudence and evangelical simplicity. ${ }^{32}$ That notion of episcopal grace and character was contained too in the hagiographic writing of the Jansenist cleric Isaac Le Maistre de Sacy. Of the same generation as Olier and Godeau, Le Maistre's life of Barthélemy des Martyrs affirmed that only the bishop could spread 'the grace and benedictions of Heaven' through 'the grace of his character and his person'. This grace operated through correcting, fortifying, perfecting, appeasing and consoling or, in other words, through conscientious care of the diocesan flock. ${ }^{33}$

Etampes, Camus and Godeau were among the most outspoken of bishops in questions relating to the jurisdiction and status of bishops; their actions mirrored the teaching in their hagiographic and didactic treatises. Although most authors placed themselves firmly within the episcopate's camp on these questions, one interesting exception was the Jesuit Nicolas Talon, author of a treatise on the celebrated bishop of Geneva François de Sales, during the 1630s. Talon stressed the intimate relationship between the bishop of Geneva and the Jesuits, to whom he had initially entrusted his preparation for the episcopate. Before his consecration, according to Talon, de Sales made a general confession of his whole life to the Jesuits and a private confession to Jean Fourrier, the rector of the Jesuit college at Chambéry. Thereafter, the Jesuits retained the bishop's confidence and he unerringly turned to them for spiritual direction. ${ }^{34}$ De Sales's other biographers did not stress this point, clearly 
suggesting that Talon's particular aim was to portray the Jesuits in as positive a light as possible to highlight de Sales's confidence in their advice and teachings. His preferred technique was to use a particular incident in de Sales's life to refute the criticisms of those who undermined the order's competence and claims in pastoral care. The message was clear: bishops should follow de Sales's example and entrust themselves to the advice of the Jesuits, rather than oppose them. It was a particularly timely but provocative observation given the growing ill will of many French prelates towards the order. To have earned the trust and co-operation of François de Sales was itself a major seal of approval, and thus a tremendous enhancement of the Jesuits' prestige and reputation.

On the other hand, most texts accentuated the jurisdictional authority of bishops over members of the regular orders. Etampes's Advis incorporated a number of the decrees contained in the Déclaration sur les réguliers that he had composed on behalf of the 1625 Assembly: it combined counsel on the characteristics of virtuous bishops with comprehensive specifications of their jurisdictional authority over the regular clergy. ${ }^{35}$ That assumption resonated throughout episcopal literature, and notably within Godeau's publications during the 1650s. He strongly endorsed the principles of the 1625 Déclaration and incorporated this attitude into his hagiographic works, by adapting the examples of Charles Borromeo and Augustine of Hippo to contemporary France. In his Vie de S. Augustin, published in 1652, Godeau examined the life and vocation of this early church bishop. In seventeenth-century France, religious caused 'occasions of trouble and dispute' to a degree unknown in the primitive church: 'The auxiliaries do not wish to recognise the legitimate leaders ... The submission is only in words and reverences . . . one changes the privilege of being able to serve into pretensions to command.' Augustine had held religious in high regard but this did not mean that he suffered their faults; on the contrary, he ensured that they lived properly and obediently. All bishops were the centre of diocesan unity, whose paternal instructions and 'orders for combat' should be obeyed by the regulars within their jurisdictional remit. ${ }^{36}$

Godeau reiterated this argument five years later, in his account of Borromeo's episcopate, devoting a whole chapter to the archbishop's conduct towards the regulars. Like Augustine, Borromeo held the regulars in esteem and aided them whenever possible. At the same time, he did not abandon the 'strict rules' of episcopal jurisdiction and courageously regulated religious through disciplinary acts, ordinances and visits, permitting nothing to 'diminish the authority of his charge' ${ }^{37}$ This was the correct policy for prelates: like their illustrious forebears, they should respect the religious vocation and aid regulars whenever possible, but never allow the jurisdictional authority of their office to be jeopardised. Jean-Baptiste Noulleau echoed Godeau's sentiments in his counsels to bishops, drawing on the life of Étienne Villazel, a less celebrated bishop 
of his own time. Noulleau explicitly condemned Rome's willingness to interfere in the government of dioceses and its blatant ignoring of the episcopal right to rule. Ecclesiastical discipline was put in grave danger, he warned, when the papacy upheld the regulars' supposed privileges, particularly in cases relating to the sacrament of confession. Villazel had opposed this undermining of episcopal authority, but it would be rectified only if the papacy left 'to all the holy bishops . . . the episcopal jurisdiction on all the consciences of their dioceses'. ${ }^{38}$

Intrinsically related to the episcopal-regular issue was that of bishops' jurisdictional droit divin. As the episcopate moved towards its explicit endorsement of this theory of episcopal power, it was simultaneously incorporated into contemporary works on episcopacy. Camus's writings bear witness to the doctrine's unofficial acceptance during the 1640s. Citing François de Sales to support his argument, Camus could 'see none who contradicts this [doctrine], not only regarding order, but also regarding jurisdiction', a rather disingenuous comment given that he was well aware that both regulars and the papacy felt that they possessed watertight cases against the teaching. He then added that the distinction by theologians between 'immediate' and 'mediate' jurisdiction was a creation of the previous century and simply exacerbated debate. ${ }^{39}$

Once again, Antoine Godeau's work also reflects the steady change in the episcopate's perspective. Just as his eulogy of Borromeo furnished an occasion to expound on episcopal grace, the bishop's eulogy of Barthélemy des Martyrs enabled him to express precisely his adherence to the droit divin concept of episcopal jurisdiction. When he attended the Council of Trent, the archbishop of Braga had been particularly vocal in the call for episcopal residence to be defined as arising from divine law. ${ }^{40}$ In recounting Martyrs's convictions, Godeau described the bones of the actual debate in a deceptively neutral manner, but then lambasted the Cardinal de Lorraine for his failure to hold firm in his support for the definition of episcopal residence as a precept of droit divin; Godeau's personal conviction on the subject was therein frankly articulated. He acknowledged that the cardinal compromised in order to avert schism, but still insisted that if he had not done so, then the issue would have been resolved definitively and satisfactorily. ${ }^{41}$ The fact that Godeau condemned Lorraine so firmly is significant, especially when it is recalled that he generally valued unity within the church and abhorred schism. So, he worked diligently to bring about the 1669 Paix de l'église and expressed his 'heart's joy' when it was forged. ${ }^{42}$ But he did not admire Lorraine's position since it was detrimental to a fundamental characteristic of episcopacy. This particular eulogy was published in 1665 as part of an entire hagiographic volume of worthy bishops, just following the Assembly's endorsement of bishops' jurisdictional droit divin in 1657. Indeed, Godeau proved more definite, positive and open than Camus in his embracing of the theory, and undoubtedly benefited from the Assembly's action. His 
eulogy testifies to the growing willingness of bishops to proclaim publicly and categorically the independence of their jurisdiction from papal interference on the basis of droit divin. It also reflects the bishop of Vence's willingness to adopt the example of a revered individual to further his own opinions.

In the same year, the Oratorian Noulleau used this strategy to defend precisely the same claim as Godeau. His account of Villazel's life confirmed that the bishop of Saint-Brieuc had permanently resided in his diocese, with 'never the least thought to leave it' following his consecration. Noulleau then observed that Villazel had believed episcopal residence 'to be of divine law' before slipping in the provocative allegation that the fathers of Trent and the ancient church had also considered this to be the case..$^{43}$ This was, of course, inaccurate since the Tridentine delegates had been badly split in opinion on the question, but Noulleau skated over this point in order to support his claim. Like Godeau, he resorted to hagiography to promote a particular view of episcopacy, one that endorsed extensive episcopal jurisdictional authority in dioceses. Villazel's reputation as a worthy bishop could be expected to bring added legitimacy to the theory of droit divin, just as those of Barthélemy des Martyrs and François de Sales would.

Two important points must be noted here in relation to the adoption of contemporary ideas on episcopal perfection, dignity and jurisdiction into French works on episcopacy. First, the ideas contained within them were neither unique nor original. Rather, the texts reflected and promoted ideas formulated by reformers and bishops as they struggled to deal with actual events and situations facing the contemporary episcopate. This does not imply that they played no role in the dissemination of ideas of episcopal prestige and jurisdiction, but their part was a secondary or supportive, rather than a seminal, one. Godeau and other authors used their sources and evidence in a manner which validated and reinforced particular ideas and viewpoints, with the aim of influencing their readership or confirming them in their views.

The second point to note is that there was one important exception to this alignment. Chapter 4 documented that the Jansenist bishops manifested a fuller sense of collegiality than most other bishops in the debates over episcopal jurisdiction, a more apostolic and pastoral viewpoint that underpinned their opposition to the Assembly and the papacy. In comparison, when it drew swords with the state, the episcopate as a whole succeeded in broadening its concern to encompass not just episcopal welfare but that of the universal church. ${ }^{44}$ However, the protection of both was invariably presented as an episcopal task in hagiographic and didactic works. Borromeo, according to Camus, knew that, as a prelate, he had to defend ecclesiastical interests 'like a judicious bee' defending its honey 'with the point of its sting', just as Jesus Christ had defended his temple when necessary; this sentiment was reiterated by Claude de La 
Chambre in his panegyric of the archbishop. ${ }^{45}$ Bishops were encouraged to follow his illustrious example of episcopal leadership: Jean Lemarie praised the devotion of the bishop of Saint-Malo, Guillaume Le Gouverneur, to Borromeo and hailed his defence of ecclesiastical privileges in the hope of spurring him to still greater efforts. ${ }^{46}$ So too had Ambrose and Thomas of Canterbury conserved the spiritual jurisdiction of the church with constant vigilance; like them, all bishops should know that, in fulfilling the demands of their vocation, they might face suffering, torture and, ultimately, a horrific death. Their office was 'a true apprenticeship of martyrdom', which might bring, at any moment, 'the knife on the throat' that would pour 'all [their] blood on the prepared altar'. ${ }^{47}$

The lives of more recent bishops were also harnessed to promote this aspect of episcopal duty. Le Maistre's treatise on Martyrs described the archbishop's battle with the Portuguese secular authorities to prevent them encroaching on his jurisdiction. His actions were just because he was motivated purely by his desire to defend the church, just as Borromeo was. ${ }^{48}$ Thomas de Villeneuve, the archbishop of Valencia, had also acted in this worthy manner to shield his church..$^{49}$ Likewise, François de Sales was occasionally presented as fulfilling perfectly his responsibility as defender of the church, though not nearly so often as Charles Borromeo; Antoine Godeau, in his eulogy of the bishop of Geneva, praised his courage and zeal in withstanding the efforts of temporal officials to intimidate and dominate him. According to Godeau, de Sales thought little of sacrificing his personal interests for the honour of his master and ministry. ${ }^{50}$

While Camus acknowledged that a bishop's jurisdiction was limited to his own diocese he felt that this did not preclude him from keeping a close eye on affairs outside his immediate sphere of government: 'Although bishops might be bound to care within certain limits, that one calls the diocese . . they do not however lose the care of the church in general, for the good of which they must work with all their strength. ${ }^{51}$ Episcopal communion was vital, cautioned Camus, but so too was ecclesiastical unity, and bishops had a duty to foster both as far as possible. ${ }^{52}$ It was true, Noulleau declared, that a bishop could occasionally leave his diocese, but only for its spiritual benefit or for the needs of the universal church. Of course, it was his duty to care principally for those under his charge in his diocese. Yet he must always seek the good of all the faithful and be prepared to act to that end when necessary. Villazel, according to Noulleau, fulfilled this apostolic responsibility admirably, always actively seeking 'the exaltation of the mother church'. ${ }^{53}$ Talon noted that, like de Sales, a bishop should be 'the pastor not only of a people and place, but the common father of all people, and all places . . . the head, the eye, the ear and the hand of the world and of the church'. This was to be a true fisher of souls, as Jesus and the first Apostles had been. ${ }^{54}$ Antoine Godeau called on the lives of Augustine, 
Borromeo, de Sales and Martyrs to make essentially the same point. In the fifth century Augustine had famously demonstrated his concern for the welfare of the entire church through his opposition to the terrible Donatist and Pelagian heresies that had threatened to tear the church asunder. ${ }^{55}$ Generations later, Borromeo's zeal had surpassed the limits of his diocese when he actively advised and encouraged clergy who were not under his direct jurisdiction. ${ }^{56}$ Likewise, François de Sales had reached beyond his diocese through personal contacts, publications and preaching, with the result that his charity knew 'no other limits than the entire church'. ${ }^{57}$ Godeau's eulogy of Barthélemy des Martyrs also made reference to this ideal episcopal quality, possession of which had enabled Martyrs to love his own diocesan church and the universal church, and to serve them both at the Council of Trent. ${ }^{58}$

For one so expansive on bishops' apostolic responsibility for universal spiritual welfare in his hagiography, it is a little curious to find no reference to this topic in Godeau's pronouncements on the Formulary debate and the judgement of bishops. Clearly, he regarded the actions of Borromeo, de Sales and Martyrs as worthy of emulation, and his own successive publications on the clerical and episcopal vocations were obvious attempts to follow in their steps. Most bishops tended to produce manuals for the clergy of their own dioceses; Godeau composed two treatises for the use of ordinands outside as well as within Vence. ${ }^{59}$ So he was acutely sensitive to the need for bishops to cultivate apostolic responsibility for the whole church, and tried to live accordingly and to propagate this idea through his hagiographic works. However, like the majority of French bishops, when involved in actual contemporary papalepiscopal jurisdictional controversies, he tended to neglect their pastoral and apostolic aspects and to concentrate principally on their specific implications for the episcopate. The discrepancy between his hagiographic publications and his arguments when confronted with actual jurisdictional dilemmas provides further confirmation that episcopal works reflected and disseminated ideas emanating from particular topical events, rather than the reverse.

As brought to life in didactic manuals and hagiographic texts, the accomplished prelate governed his diocese according to his divinely given power of jurisdiction. He used his power of order to mediate between God and man and to draw the faithful towards perfection. The rank and perfection of his charge necessitated a personal style of life which corresponded to his hierarchical vocation. Finally, he displayed an active concern for the well-being of the entire ecclesiastical community. These were fundamental principles of government and authority, but were, equally, crucial elements of episcopal spirituality and pastoral work. Yet they were not simply abstract tenets; rather, their advocates intended that they be incorporated into the vocations of the bishops whom 
they saw nominated to dioceses, administering dioceses and participating in Assemblies.

Both bishops and non-episcopal writers used the lives of ancient and contemporary bishops to portray the ideals to which seventeenth-century French bishops should aspire. Following the contemporary fascination with the fathers of the early church ${ }^{60}$ they particularly resorted to the Apostles, Timothy, Augustine, John Chrysostom, Gregory the Great and Ambrose, as well as to the ultimate pastor, Jesus Christ. Of medieval bishops, only Thomas of Canterbury rivalled them in prominence, and he was generally singled out for his defence of church rights against the English monarch, Henry II. ${ }^{61}$ Episodes from the lives of bishops and the advice that they had given on the episcopal vocation were recorded and discussed in detail for the benefit of the reader and, whenever possible, related to particular events currently affecting French bishops. Thus, Claude Morel portrayed the anti-Jansenist bishops of the Assembly as heroic descendants of Augustine, successful conqueror of the Pelagian heresy. They were, he claimed, filled with 'the dignity of their character', Augustinian zeal and 'God's knowledge'.${ }^{62}$ In fact, authors regularly referred to current events in their texts, whether by composing an entire work in reference to a topical controversy concerning episcopacy, like Morel, or by making specific observations during the course of their treatise. The dissections of jurisdictional droit divin and of the regulars' rights were instances of this.

Among bishops of the contemporary era, it was Charles Borromeo and François de Sales who were by far the most influential and who received most attention from bishops and authors. Apart from editions of their own works, the prelates were each the subject of many French texts relating to the episcopal vocation. After his death in 1622, de Sales proved just as favoured a subject as the late archbishop of Milan, with at least eight treatises on his life by French authors. Borromeo, the foremost episcopal model of the late sixteenth century, merited six treatises, plus translations into French of several hagiographic biographies by non-French authors. Both bishops were far more popular as principal subjects for treatises than any ancient bishop or French prelate: excluding Godeau's Éloge des évesques, just four works on ancient prelates and ten on contemporary French bishops were published between 1600 and $1670 .^{63}$

Regardless of their biographical preferences, all publications stressed that even the exemplary administration of a diocese was not sufficient to discharge the episcopal burden. Episcopal and other authors often used the customary Pauline observation that although the office was a good work, it was a heavy burden, in terms both of responsibility for souls and of a bishop's ultimate accountability to God. ${ }^{64}$ For that reason, it was essential that one possessed a true vocation. Reluctance to accept a nomination, because of a feeling of personal unworthiness, was the surest indication that one had a legitimate calling 
to the episcopate. Camus, quoting de Sales's advice to him, advised that a potential prelate should assess his capacity for the office and seek the advice of wise counsellors while praying to God for guidance. ${ }^{65}$ When contemporaries emphasised the profound soul-searching that a potential bishop had to undergo before accepting the care of a diocese, they were logically led towards discussion of the core episcopal virtues. These basically amounted to the Christian virtues, which every Christian ought to possess in some degree. The difference between the virtues of a bishop and all others, however, was that the prelate should possess these in eminence, to a far greater extent than any other member of Christ's faithful. As Bérulle and his disciples observed, there must be a correlation between the wondrous perfection of the episcopal office and the personal perfection of its incumbents.

In 1625, shortly after the death of de Sales, the Assembly of Clergy petitioned the papacy for his beatification. This call was repeated in 1635 and again in 1645,1650 and 1655 . In the letter of petition that the deputies sent to Urban VIII in 1625, they noted the exemplary life of the late bishop of Geneva and his piety, humility and moderation. ${ }^{66}$ These, agreed authors of hagiographic works on de Sales, were qualities which he had possessed in abundance. ${ }^{67}$ They were also attributed to other illustrious bishops and deemed essential to a good bishop. ${ }^{68}$ But what exactly did contemporaries mean when they used these words to describe a worthy prelate, the type of paragon that they wished all French bishops to emulate?

Piety embraced all other episcopal qualities, wrote Camus, since 'if all Christians are called a holy nation, how much more holy must be those who govern them spiritually'. ${ }^{69}$ If a prelate managed to achieve this virtue, then he would be 'the copy of his prototype ... Jesus Christ, as much as it is possible for human fragility'. ${ }^{70}$ Essential to episcopal piety were constant trust in God and an entire willingness to follow his wishes. A bishop knew what these were by frequent prayer, reading of Scripture and celebration of the mass, through which God revealed his will to his servant and granted him the strength to implement it. Piety, then, sanctified all external acts and seasoned them 'with the salt of prayer'. It was intricately related to wisdom, and could not be achieved without it. A bishop should be capable of guiding others, mediating the truth of revelation to them and interceding on their behalf; it was essential that he himself was particularly close to God and that he was capable of interpreting the divine mysteries: 'He should be so devoted to prayer, that he knows already by experience that he will be able to obtain from God what he asks of him'.7

Humility was one of the most prominent virtues within works on episcopacy, highlighted in the hope of counterbalancing the accent placed on the great dignity of bishops and on the powers which the office granted its incumbents. Even if a bishop was pious, moderate and wise, he should always remind 
himself of his unworthiness before God and strive to eradicate his shortcomings, preserving 'a spirit of low esteem', which always 'holds them to be vile and abject to their own eyes'. ${ }^{72}$ It was not enough for a bishop to possess the same degree of humility as an ordinary Christian, Maubourg stressed; he must, like Thomas of Villeneuve, be far more humble and self-effacing than others. ${ }^{73}$ On Borromeo, Camus wrote approvingly that, despite his noble birth and titles, the archbishop never allowed any 'tumour in his truly humble heart'. Instead, he lived a simple and penitent life of constant labour. ${ }^{74}$ In fact, their acute feelings of unworthiness had traditionally distressed saintly bishops, and it was only their trust in God and complete submission to his will that had allowed them to continue in their vocation. ${ }^{75}$

The Mercuès conferences demonstrate the fact that at least some French bishops were consciously striving toward this ideal: both stressed the fact that prelates must be as humble as Jesus, their model, had been ${ }^{76}$ Their instigator, Alain de Solminihac, reminded himself to be 'strongly reserved in talking about myself . . . I will abstain from all discourse which will be able to turn to my praise . . . I will not talk of the faults of others, if I am not obliged . . . Humility and mildness will be my two dearest virtues. ${ }^{177}$ Indeed, like Godeau, Solminihac displayed a marked reluctance even to accept his nomination to Cahors in 1636, telling those who tried to encourage him to change his mind not only that was he unworthy of the honour, but that he feared that the episcopate would expose him to the temptations of the world. ${ }^{78}$ Only after much prayer and spiritual advice did Solminihac finally assume his position as bishop. He was anxious, however, to ensure that he would never give in to the temptations of pride or self-indulgence, and his rule of life expressly recommended that he remain 'always in the presence of God' through concentrating on the type of spiritual matters that would 'inflame [him] with love of God'. He vowed that, as Christ's 'living copy', he would not have any will but that 'of my God' and that he would not perform any action that was not inspired by God. In this absolute self-abnegation, he would be joined with Christ himself, for Christ would give the strength and virtue to animate the bishop's imitation of his wholehearted service of God. ${ }^{79}$ These ideas had surely been fostered by a long friendship with Jean Barrault, bishop of Bazas and Arles, a dévot mentor with ties to the Bérullian circle and to François de Sales. In letters to Solminihac, Barrault did not hesitate to advise his younger friend on the necessity of following God's will without regard for oneself. He asked Solminihac to understand that self-abnegation would enable one to ignore the world's temptations, and that the suffering of episcopal life would ultimately bring one to Heaven. ${ }^{80}$

However important these accomplishments were, authors and bishops agreed that it was impossible for a prelate to live up to the dignity and perfection of his charge without charity and zeal, possessed, like the other virtues, in 
eminence. Charity was the 'proper virtue' of bishops ${ }^{81}$ understood both in the manner of compassionate love for God and neighbour and in the sense of a bishop's organised aid to the needy. In both conceptions, the bishop's compassion, patience and clemency in dealing with the faithful were to act as an example to them, so that they too would act charitably towards their fellow men. When judging sins, bishops should use prudent charity, showing mercy when necessary and applying rigour only when useful. ${ }^{82}$ They were also obliged to undertake extensive works of charity, through care of the poor and sick. Once again, the examples of Borromeo, de Sales and Martyrs proved especially powerful, ${ }^{83}$ and prelates were reminded that they were not 'highwaymen' who held their dioceses to ransom. In fact, they were not even the 'true masters', but 'simple managers' of their revenues. ${ }^{84}$ Although they were permitted to administer their familial inheritance if necessary, bishops were never to waste ecclesiastical goods or favour their relatives with grants from the church's patrimony, for their first loyalty lay with the diocese whose spouse they were. ${ }^{85}$

There are abundant examples of bishops who regarded themselves as the temporary guardians of the church's goods, and, in particular, who spent most of their revenue, and even any familial wealth, on caring for the needy: Cospeau, Solminihac, Pavillon, Choart de Buzenval, Caulet, Fouquet de la Varenne and Le Camus. ${ }^{86}$ Indeed, alms-giving was one subject of the letters exchanged between Caulet and Le Camus: the inexperienced Le Camus requested Caulet's advice on the most efficacious means of administering alms and was rewarded with a short memoir outlining his obligation to distribute frequently and to the deserving. These were the rules that guided Caulet's celebrated generosity; he sold his own valuables to feed the needy of Pamiers. ${ }^{87}$ Some bishops, like René Le Sauvage, left all their worldly goods to the poor when they died, though the wills in which they made their bequests are not necessarily a reliable indication of their attitudes towards episcopal luxury or the poor over the course of their episcopal careers.$^{88}$ Indeed, even the conscientious Henri de Sponde and Fénelon were amongst the many bishops who left their possessions to their relatives rather than to the poor, an indulgence that would have been heavily frowned upon by Solminihac and Camus. ${ }^{89}$ Because of the long years that they spent in charitable work, both men died with practically no belongings or savings and could not have benefited their families even if they had wished to do so. ${ }^{90}$

Because charity sprang from love of God and love of one's flock, it was vital that a bishop learn to endure personal trials and sacrifices if he were to serve both adequately. ${ }^{91}$ For the Jansenist bishops, their apostolic crusade on behalf of the entire church fulfilled that criterion. Yet even though other seventeenth-century bishops did not share the quartet's crushing pressures they could also adopt the language of charity and martyrdom to understand the 
purpose of episcopal suffering. Positively, injuries to his person, traps and persecution enabled a bishop to follow in the footsteps of Christ; as Antoine Godeau commented, bishops were more like Jesus than any other member of the church, and their trials offered them the opportunity to imitate his earthly torments. Each should expect that 'one charges them of injuries, that one gives a bad sense to their most innocent actions, that one erects traps for them, that one mocks their remonstrances, and that one persecutes them'. Godeau explicitly called this testing life a martyrdom, a martyrdom of the spirit that must be endured for the greater good of his soul and the church of Christ. ${ }^{92}$ Like the beleaguered bishop, Christ had entered into 'sufferings, labours and ignominies; and finally he offered himself in sacrifice to the Cross'. Godeau was keen to apply this principle to his own life to give purpose to the difficulties that he encountered in his diocese. ${ }^{93}$ He welcomed unavoidable opposition as a means of cultivating the Christ-like virtues of holiness and zeal: 'I must render them benedictions for their injuries, and service for their persecutions.' In spotting 'roses among the thorns', Godeau knew that 'the bishop the most removed from his patria, the most destitute of all human help, and of all consolation, the most mistrusted, the most persecuted' could thank God for the opportunity to become 'more similar to him than others'. ${ }^{94}$

Every day of his episcopal life, the bishop was presented with challenges and temptations which could be transformed into propitiatory offerings to God for his own sins and the sins of the faithful. ${ }^{95}$ Godeau suffered desperately from loneliness in remote Vence. As a native of Paris, a member of the Académie Française, and a natural extrovert, he found his isolation from news and society very trying. Reflecting on his sacrifice in leaving Paris, he consoled himself with the knowledge that he could turn his trials into positive lessons: the good bishop should gaze on God and not on the world, or as Gregory the Great had termed it, be in the world, but not of it. Naturally, he would encounter despair, but, even in those dark times, he had to soldier onwards, like Paul and the Apostles. ${ }^{96}$ Bishops could only do so if they were 'dead to themselves', an essential quality that the humble Godeau was sure that he lacked. ${ }^{97}$ Adopting a classic doctrine of Bérulle et al., Godeau argued that if the bishop endured his scourges through steadfastly gazing on God alone, then he simultaneously sacrificed Christ and himself to God. In suffering like Christ, the bishop was united with him. ${ }^{98}$ A recent example was Alain de Solminihac, one of the few French bishops included in Godeau's Éloge des évesques. In that work, Solminihac was presented as a bishop who had completely abandoned himself to God, so that he became like a 'Christian infant'. That had produced two marvellous results: the bishop's detachment from the world meant that his actions had been informed solely by his charitable love for God; equally, he had been capable of immense sacrifices for divine glory. ${ }^{99}$ 
Solminihac's life displayed the zeal so beloved by French authors: zeal for his own moral and spiritual welfare and zeal in ensuring that his charges attained their heavenly reward also. A favoured epithet of French authors to define the ideal bishop was 'irreproachable', used interchangeably to describe responsible administration and virtue: it was essential that a bishop be truly spiritual and holy as well as an efficient and responsible supervisor of his diocese. This was why Solminihac chose Nicolas Sévin as his successor for Cahors: Sevin was what Solminihac considered to be an 'apostolic man' and, therefore, well equipped to be a diocesan bishop. Solminihac made sustained efforts to ensure that his wish would be granted, by repeated reminders, through Vincent de Paul, to the queen regent of her promise to allow him to choose just such 'an apostolic man' as his successor. In due course, Sevin was installed as coadjutor and then bishop of Cahors, fulfilling Solminihac's hope that his episcopal style would be continued following his death. ${ }^{100}$

For Solminihac, episcopal activity was closely connected to personal virtue, since responsible administration was assumed to supplement virtue and to bring bishops closer to perfection and, therefore, nearer to God. This widely held understanding of administration was framed by the decrees of the Council of Trent, but was underpinned by a particularly spiritual point of view. Of course, the preliminary requirement for successful administration was residence. As the hinges on which religious life turned, bishops ought to be at 'the centre of their diocese', and therefore able to care for it personally and effectively. ${ }^{101}$ It was for this reason that Solminihac so strongly urged Bishops Jean de Lingendes of Sarlat and Jean d'Estrades of Périgueux to reside in their dioceses. He failed ultimately in both cases: Lingendes left his diocese after a short sojourn there and Estrades never even set foot in Périgueux. ${ }^{102}$ Undeterred, in 1654 Solminihac advised the newly appointed bishop of Périgueux, Cyrus Villers la Faye, with whom he was closely associated, that residence, accompanied by visitations, was absolutely vital to successful administration. ${ }^{103}$

Residence, declared Camus with his usual candour, was better than nothing at all, but it must be accompanied by the fulfilment of other duties: visitations, synods and preaching. ${ }^{104}$ In fact, a bishop's entire life should be a perpetual visitation, a constant round of teaching, supervision and administration. ${ }^{105}$ 'Communicating his presence and his charity to the whole body of his diocese, [the bishop] spreads the graces and the blessings of Heaven on all those who are its members. ${ }^{106}$ Borromeo was by far the most popular example here, recognised as one whose administration had most effectively put Trent's directives into action. Ancient bishops like Augustine or Ambrose did not figure in this context. Nor, interestingly, was it generally a prominent subject in works on de Sales, except when he was presented as the imitator of Borromeo. The visitations of Barthélemy des Martyrs and Thomas de Villeneuve 
were also lauded, ${ }^{107}$ but since far more treatises related to Borromeo than to either of these it was the administrative practice of the archbishop of Milan that was presented as the model for French bishops.

Many bishops took Camus's connection between preaching and residency to heart: in his sermons to his frequent diocesan synods, Henri Arnauld spoke passionately about the apostolic duty of preaching passed to him from the New Testament: 'I know that according to the Gospel, the bishop is the light which must illuminate the whole church; according to Saint Paul he is the father who must instruct his children. ${ }^{108}$ The new emphasis on preaching owed much to the Renaissance revival of classical studies, but was more directly indebted to the Council of Trent and to the legacy of leading bishops like Borromeo, Martyrs and de Sales. ${ }^{109}$ Preaching had become an essential accomplishment for any bishop, with orators celebrated for their mastery of it. ${ }^{110}$ Publications usually offered detailed guidance on the manner in which bishops ought to preach: their sermons should be simple, clear and to the point. Since the goal was to illuminate and perfect listeners, content should be suited to their ability to understand and contain nothing that could confuse them. ${ }^{111}$ Flattering plaudits could be earned by rhetorical flourishes, but it was more important to move people to faith than to win compliments and material rewards. Like Augustine, Godeau advised, bishops should preach humbly, with zeal and sincerity and with a pure and knowledgeable doctrine. ${ }^{112}$ The style of de Sales was also recommended to prelates; his chief aim and advice had been to persuade people towards faith, rather than to please them by elegant words. ${ }^{113}$

Bishops were 'the salt of the earth and the light of the world', whose preaching seasoned and purified the souls of the faithful. ${ }^{114}$ Pavillon's rule of life obliged him to preach on feast days and the first day of each month, ${ }^{115}$ and other evidence suggests that many French bishops also preached regularly. ${ }^{116}$ To encourage the timid, authors assured them that the spirit of God would animate their words so that they would have great force despite their simplicity. Jesus himself, noted Camus, had used simple but effective words and images. If a bishop was personally pious, his faith would shine through his words and excite his listeners to conversion and belief. ${ }^{117}$ Here, authors scored a deep link between the personal episcopal virtues of piety and wisdom and responsible administration. The bishop's example, the act of fulfilling his duty in obedience to God, was as important as the content of his teaching. Of course, it was naturally also desirable that bishops be knowledgeable in doctrine. Study, prayer and spiritual reading were the only means by which this could be cultivated; the fruits would guide the bishop's own life and thoughts and enable him to enlighten others. Bishops were doctors, but their knowledge could not be likened to that of those who acted as secular leaders, for it was 'the knowledge of God', the 'celestial bread of the evangelical word'. ${ }^{118}$ 
To the Mercuès participants, prayer was such a fundamental episcopal activity that their final recommendations included entire sections on this most necessary of tasks. Habitually undertaken, prayer would foster 'great detachment from all things, a destruction of ourselves, profound humility, great patience'. It functioned as a supportive foundation for the episcopal vocation because it was the primary defence against egoism, complacency and cowardice. Prayer simultaneously offered a path to God, for through it the bishop could intercede with God on behalf of the faithful while abandoning '[himself] to the movements that it will please God to give us, and to all that he will wish to do with us' ${ }^{119}$ Several kinds of prayer were possible: eucharistic celebration, meditation on the Scriptures and contemplative reflection. ${ }^{120}$ Through each, the bishop could gain the personal enlightenment so essential to effective teaching and so necessary if he was to escape from the 'obscurity and darkness' wrought by $\sin .{ }^{121}$ In developing the intimate relationship with God that prayer offered, therefore, bishops would learn God's will and would be given the grace to fulfil it. ${ }^{122}$ All these assumptions lay at the root of Condren's advice to Zamet, and inspired Solminihac's and Pavillon's promises to pray daily and intensely for at least two hours. ${ }^{123}$

In the late sixteenth century, Charles Borromeo had been the dominant model for French bishops, with his administrative policies adopted wholesale by reforming prelates in the absence of suitable contemporary French models. He had to share the limelight, however, with François de Sales, the late bishop of Geneva, in seventeenth-century French episcopal texts. Between them they received far more attention than any other bishops, ancient or recent. Saint Martin referred indirectly to this when he published his treatise on Thomas de Villeneuve in 1659. Admitting that Villeneuve had not been particularly popular in France up to this point, Saint Martin feared that his Spanish background would discourage wider readership in the future. ${ }^{124}$

Borromeo and de Sales provided bridges between the bishops of the ancient church and those of the present, in that they were held to possess the superb qualities of Augustine, Ambrose and others. Yet their importance lay equally in the facts that they offered original contributions to conceptions of the episcopal vocation. Like Borromeo, de Sales was famous in France; in addition to his contact with French bishops like Camus, he was also the author of two works of devotion which became exceptionally well known in seventeenth-century France. ${ }^{125}$ The bishop's impact upon episcopal pastoral ideals is complicated by the fact that, to some extent, he was understood in seventeenth-century France as an accomplished imitator of Borromeo, a prelate who mirrored the actions of the archbishop of Milan in the administration of his own diocese. He, too, had visited his diocese frequently, introduced clerical reforms 
and instructed his clergy and laity by preaching and example. He was, according to Olier's Discours sur François de Sales, the 'imitator and perfect copy of Borromeo' in his diocesan government. ${ }^{126}$ It was not only the clerical reform school which held this line of thought; others echoed it. In 1632, Cavet heralded de Sales's imitation of Borromeo in his zeal for an exact liturgy, preaching, sacrament administration, alms-giving and clerical discipline. ${ }^{127}$ Bishop Maupas Du Tour made the same observation when praising the reforming administrations of both bishops. ${ }^{128}$ In his administrative practices, therefore, de Sales was considered to be 'another Saint Charles', ${ }^{129}$ and acted as a straightforward link between Borromeo and contemporary French prelates; they were to introduce Borromean practices just as de Sales had done. Still, he was not simply seen as an imitator of the late archbishop, that is, as a 'Borromean disciple', even though historiography has often portrayed him exclusively in this way; ${ }^{130}$ he emerged as a model in his own right, separately from his emulation of Borromean administrative patterns. For whereas authors concentrated mainly on Borromeo's governing practices, they chose to spotlight de Sales's personal episcopal virtues. When Jean Lemarie compared Bishop Le Gouverneur of Saint-Malo to Borromeo, for example, it was entirely on the basis of both bishops' administrations: Le Gouverneur's residence, visits, synods, provision of good clergy and defence of church rights made him worthy of a Borromean tribute. ${ }^{131}$

Like a minority of prelates before 1600, many seventeenth-century French bishops did use the Borromean framework as the basis for their administrations. This model manifested itself, as Marc Venard and numerous diocesan and biographical studies have shown, in congregations, conferences and confessional practices. The availability of the Acta ecclesiae Mediolanensis, even before its publication in France in 1643, meant that many bishops used it as a basis from which to implement Trent's demands for diocesan reform. ${ }^{132}$ Unsurprisingly, La Rochefoucauld owned a copy (as well as two copies of the many vitae of the saint), but Solminihac possessed no fewer than three copies and Godeau also had a copy for use in his small diocese. The bishop of Vence particularly treasured his Acta because it was one that Borromeo had given to one of his Milanese curés. ${ }^{133}$ Diocesan synods and visitations were fundamental features of the episcopates of all reform-minded French prelates, ${ }^{134}$ and bishops who were themselves influenced by Borromean ideas encouraged others to implement them in their dioceses. Nicolas Sévin, bishop of Sarlat, asked Solminihac to lend him a copy of his Acta for an extended period. ${ }^{135}$ The bishops of the 1649 Mercuès conference pledged to carry out regular visitations, hold diocesan synods and ensure the ordination of good clergy by the establishment of seminaries, policies which they were already engaged upon. ${ }^{136}$ These promises fulfilled Trent's directives, but both Pavillon and Solminihac declared themselves 
influenced by the example of Borromeo's government; Pavillon for the archbishop's untiring administration and Solminihac for his institutional policies. Solminihac wrote to Choart that he had established congregations forane 'following the example of those that Saint Charles Borromeo established'. ${ }^{137}$

A considerable number of other bishops consciously modelled their administrations on Milan; François de Sourdis of Bordeaux is a classic example. While in Rome shortly after his appointment to the episcopate, he resolved to organise his diocese according to Borromeo's model. Thereafter, he maintained a regular correspondence with Federico Borromeo, discussing diocesan matters with him and seeking guidance for his episcopal activities. ${ }^{138}$ Sourdis very much favoured Charles Borromeo's systematised approach to reform, so much so that he held twenty-one diocesan synods during his episcopal tenure, one almost every year, and established congregations forane to educate and discipline the parish clergy. ${ }^{139}$ When he held his provincial council in 1624, it was in explicit imitation of Borromeo, 'the ornament of the Milanese church', while his visitations were carried out with the regularity and attention to detail of those of the Milanese archbishop. ${ }^{140}$ Sourdis's sustained devotion to Borromeo's example led him to organise solemn processions, exposition of the Holy Sacrament, a pontifical mass and indulgences on the occasion of the late archbishop's canonisation in 1610. A panegyric of Charles Borromeo was also preached and a surplice presented to the parlement as a relic. ${ }^{141}$

Borromeo's impact on the French church was potent right through the seventeenth century. He was a freshly canonised saint, familiar to clergy and devout laity. His Instructions aux confesseurs proved hugely influential upon penitential practices down to the modern era, and contributed to a rigorous vein of penitential catholicism among the parish priests of France. ${ }^{142}$ Yet the legitimate claim that he bestrode the century 'like a colossus' can be a rather blunt instrument, obscuring the nuances of the archbishop's impact. One of the major dangers that invariably accompanies any blueprint, of course, is that it will lose its stimulus for progression, so that its 'ways' become definitions, set in stone, admired and copied, but not further elaborated. This is nowhere more evident than in the question of Borromeo's force as an episcopal ideal: it was starkly apparent in late sixteenth-century France, when bishops made no adaptations to the Borromean model, but simply followed it closely. The seventeenth century, however, reacted rather differently. Here, the archbishop's specific importance lay in the fact that he was first and foremost an administrative model. This should not suggest that his personal virtue was not admired or that bishops were not recommended to imitate his humility, his prayer, prudence and wisdom. But it was chiefly his coherent, organised and easily accessible system of visits, synods and congregations which were proposed as the elements of a workable diocesan pastorate and which proved most influential 
among French bishops. In this respect, conscientious bishops of the seventeenth century did not differ from their predecessors of the late sixteenth. Yet while Borromeo's personal stringency was admired, it was not necessarily presented as the ideal to be copied. He was considered too austere in his personal life and too strict for most French bishops to adopt his mortified manner of life.

French bishops and authors were not the first to reject aspects of the Borromean episcopate, though it had not previously been done publicly. The bishop of Bologna, Paleotti, had criticised what he considered to be Borromeo's excessively centralised control of his clergy, his extreme austerity and his inability to compromise with those less rigorous than himself. ${ }^{143}$ Agostino Valier, another prominent post-Trent bishop, privately reproved Borromeo's rigid defence of ecclesiastical jurisdiction in his correspondence with Federico Borromeo, and counselled Federico not to attempt to imitate his uncle in all aspects of his episcopate. ${ }^{144}$ Yet these opinions were only expressed privately and these men were certainly not willing to publish their views or to challenge the rapidly developing image of Borromeo as the ultimate model for all prelates. In the seventeenth-century French church, however, as bishops and reformers attempted to develop an ideal of episcopacy based on older traditions but responsive to immediate needs, they were unwilling simply to accept en bloc all aspects of the Borromean ideal. Rather, they developed a combination of the most relevant elements of Borromeo's and de Sales's episcopates and proposed this as the blueprint for contemporary French bishops.

Every French treatise on Charles Borromeo referred to his magnificent austerities and his life of physical penance. ${ }^{145}$ Camus lauded the 'strange and extraordinary mortifications' by which Borromeo had reduced his body to servitude. In particular, Camus commented, Borromeo had wished to cultivate a spirit of chastity and humility through the subjection of his body to the divine will. His disciplines included a very frugal diet of bread and water, restricted sleep and extremely grim living conditions. That simplicity was all the more impressive to Camus because it was cultivated amid the material splendour of the Milanese archbishopric and by a man who had been born into a powerful noble family. ${ }^{146}$ This observation had particular application to many bishops in seventeenth-century France. Étienne Cavet adopted it enthusiastically when he described Borromeo's 'one thousand incommodities', his nocturnal vigils, abstinence, prayers and bodily mortifications. ${ }^{147}$

However, although Camus displayed the greatest respect for Borromeo's feats in his homilies, he made it perfectly clear that he did not want his brethren to imitate them. 'We are no more than the cold ashes of which our predecessors were the blazing coals. ${ }^{148}$ Others were less scathing in their language, but they acquiesced with Camus's basic position. Olier agreed that Borromeo was a bishop possessed of 'miraculous and divine virtue', but did not shy from arguing 
that the austerity and rigour of his life were simply too much for most bishops. ${ }^{149}$ Godeau made precisely the same point in his eulogy of the late archbishop, recounting how Borromeo had undertaken tremendous penance throughout his career by offering his body for the sins of men. In sanctifying his own body through disciplines, therefore, he had sanctified others. But, wrote Godeau, 'The life of Saint Charles is not a regular example that all bishops have to follow. ${ }^{150}$ He pertinently observed that Christ had not lived an acutely austere life while on earth. Rather, he had lived as a man in the world, eating and drinking just as men did. Though his Apostles had practised their own austerities, as had other early bishops like Ambrose and Martin of Tours, Christ was obviously the principal model for bishops, and if he had avoided corporal mortification then so should they. ${ }^{151}$ Godeau had offered the same ideal in his eulogy of Augustine just five years before. Although he had to admit that the saintly Augustine had practised corporal penitence, Godeau was at pains to stress that he had only done so only with the utmost circumspection and prudence. ${ }^{152}$ Obviously, Godeau was extremely anxious to discourage, or at the very least to restrict, physical mortification by bishops. To do so, he, like Camus, was not above implicitly criticising the practices of revered members of the Catholic episcopate, even when he did not have the confidence to condemn them outright.

Even a cursory examination of the published reflections, on the other hand, reveals an authorship that saw in de Sales a bishop who had neither approved of nor indulged in constant and radical corporal austerities, but who had, nonetheless, managed to live a life of supreme sanctity. Although Godeau agreed that de Sales did not overly indulge in the material offerings of life, his image was far from that of a bishop occupied with extreme bodily penance. ${ }^{153}$ Olier's panegyric of the late bishop observed that the only external mortifications undertaken by de Sales had been the mockeries and contradiction inflicted by others, ${ }^{154}$ and Caussin highlighted de Sales's moderate approach to fasting, vigils and possessions. ${ }^{155}$ Both commentators then proceeded to paint the bishop not as a figure who purposely inflicted tremendous physical suffering on his body, but as a man who had followed 'the cross of God' through mortification of the heart and spirit. He was to be imitated because of 'the grandeur, ease, and the mildness of all his actions'. ${ }^{156}$

Again and again, de Sales was presented as a bishop who had perfectly abandoned himself to God's will, an abnegation most famously apparent in his charity towards all. De Sales's episcopate was considered to have been very special indeed. His will had constantly been turned towards the good, even in the face of temptations and pressures from secular society. His charity had propelled the crucifying sacrifices and suffering of his episcopal life, for it was the supreme manifestation of love of God and mankind. ${ }^{157}$ Bishops were constantly encouraged to adopt Salesian charity, on the basis that if anything could 
overcome the human frailties of ambition and selfishness, it was this kind of compassionate love. Naturally, de Sales's life had required discipline, for it had often been difficult for him to resist sin, but this was a discipline willingly undertaken in charity. It was also an interior discipline of the will, rather than of the body, a 'poverty of the spirit' whose principles fitted comfortably with the doctrines of Bérulle, Olier and their disciples: their contemporary stress on the notions of suffering sacrifice, self-abnegation and the death of the self tipped the balance towards mental rather than corporal discipline.

Vincent de Paul offered a perfect example of this alignment when he advised Louis Abelly on the worries that bishops were forced to endure when they clashed with regular clergy in their dioceses. He told Abelly that the late bishop of Comminges, Donadieu de Griet, and Bishop de Sales had here offered perfect examples of conduct. Both had rejected regulars' resistance to their authority with a combination of firmness and charity, but had been sanctified through the suffering that they endured to defend proper ecclesiastical discipline. ${ }^{158}$ When Étienne Caulet was plagued by rebellious priests in 1648, Jean-Jacques Olier was able to advise him that if his heart would only remain faithful to Christ, 'the rest is nothing'. His endurance of trials and devotion to God's wishes would bring its heavenly reward. ${ }^{159}$ Olier even composed a little prayer of supplication to God, which asked him to produce bishops with 'a spirit of sanctity and separation' from the world. ${ }^{160}$

Olier characterised the Salesian episcopate as 'mortification of the spirit, founded on the spirit, and operated by it, dividing the flesh from the spirit'. Linking de Sales's thought with his own theology, he declared that this type of penitence and suffering was sure to destroy human vices. ${ }^{161}$ Other authors often used the language of the French school's reformers to illustrate the bishop's particular virtue. Nicolas Caussin's treatise on de Sales admitted that physical mortification held some value but claimed that interior mortification, the 'cross of God', was the most admirable virtue of all. The whole of François de Sales's life was marked, he concluded, by this. ${ }^{162}$ Even Godeau, himself a bishop, acknowledged that bishops need only live reasonably simply and penitently, using prudence to mark the limits of their austerity. Charity, he said, the touchstone of de Sales's episcopal life, was the most important feature of episcopal actions, rather than extreme mortification. ${ }^{163}$

At the same time, however, seventeenth-century bishops and reformers did not denigrate the memory of the red (or physical) martyrs. When describing actual martyrdom, they stuck firmly to traditional language and principles. As it had been for the early church, martyrdom was a wondrous vocation involving patient suffering, endurance of insult and injury and, ultimately, the shedding of blood, in order that one could witness to Jesus Christ. One example was Saint Savinian, archbishop of Sens, who was thought to have been 
one of the original seventy-two disciples sent forth by Peter 'to plant this vine and to cultivate it well'. ${ }^{165} \mathrm{He}$ was a perfect example of apostolic mission for his descendants to follow, remarked his biographer, Étienne Binet, and a bishop who 'carried a heart of gold' and 'a soul of diamond'. ${ }^{165}$ Savinian had not only worked energetically to convert and care for his people, he had also been a martyr for God. ${ }^{166}$ Yet why had God permitted the martyrdom of Savinian, his apostle bishop? For Binet, this was a glorious fate, in which the archbishop had been able to emulate Christ, who had willingly shed 'his precious blood to redeem souls' ${ }^{167}$ Martyrdom offered an example of heroic sacrifice to those who had not yet been converted through Savinian's preaching: 'It is virtue which talks by these mouths of blood, and none can resist the rhetoric . . . of the magnanimous and invincible patience of a true servant of Jesus Christ. ${ }^{168}$

Binet presented Savinian's martyrdom in classic terms: patient devotion to the faith and to his people, suffering and persecution, enduring loyalty to Christ until his excruciating death, and a just reward in Heaven for his loyal sacrifice. Still, it is obvious that even Binet did not regard Savinian's death as a literal model for contemporary bishops, a sentiment that was strongly echoed by other reforming writers. They did not wish their bishops to die for the faith, even if the opportunity had been present in seventeenth-century France. Instead, they displayed a pronounced distaste for any kind of physical suffering. This was certainly a departure from the middle ages, when the lives of individual saints had frequently been characterised by acute food and sleep deprivation, as well as corporal punishments. Even in the seventeenth century, these kinds of 'buffeting' disciplines were far from obsolete. ${ }^{169}$ Even so, Isaac Le Maistre was able to argue that the austerity of the religious life was not proper for the episcopal, although Martin of Tours and Gregory the Great had transferred their monkish austerities to their episcopal vocation. Borromeo might have followed their example, Le Maistre added, but that was because he too was blessed with an extraordinary 'love for humility and for poverty'. ${ }^{170}$ Other bishops were not obliged to take this path.

In contrast, de Sales's interior mortification and episcopal charity were particularly appealing to his French admirers. By raising their profile, he presented a more imitable personal sanctity than Borromeo, an example that most bishops could practically be expected to follow. Camus's emphasis on charity in his writings sprang directly from his close links with Salesian spirituality; this close associate of the bishop of Geneva was one of those most involved in spreading his spirituality and reputation. Pavillon too was particularly influenced by de Sales, whose compassionate charity he was keen to replicate in his relations with others. ${ }^{171}$ Perhaps nobody, however, articulated the factors driving the Salesian episcopate with more precision than Bossuet, who, shortly before de Sales's canonisation, produced a well-crafted panegyric of the late 
bishop that compared the Borromean and Salesian episcopates in order to highlight the best qualities of both. Each man had been of extraordinary and edifying sanctity, Bossuet began, though they were of quite different talents and conduct. For Borromeo had renewed religious life through administrative reforms, while de Sales had done so by his cross, with 'his thorns, his detachment and his sufferings'. ${ }^{172}$ But having pinpointed de Sales's particular form of interior mortification, Bossuet then turned to the extraordinary charity that had characterised his episcopate. This virtue, so particular to the bishop, had won him many hearts, when with compassion and patience he had led them towards God: 'Never had a man practised this innocent ruse and this salutary intelligence better than the holy bishop of whom we talk. ${ }^{173}$

Worried that the conscientious François Fouquet would wear himself out with labour and mortification Vincent de Paul begged the bishop to moderate his extremities so that he would be able to continue to serve God in the long term. ${ }^{174} \mathrm{He}$ was also acutely concerned when his friend Alain de Solminihac expressed his willingness to expose himself to illness and death by personally ministering to the plague-ridden. ${ }^{175}$ Yet, among others, de Paul strongly counselled him against such an extraordinary sacrifice, and wrote that Borromeo's action, which Solminihac hoped to emulate, arose from a very particular divine inspiration and did not have to be imitated by other bishops. Rather, Solminihac should assume a supervisory role, organising and encouraging spiritual assistance as well as providing material aid but avoiding direct exposure to the plague himself as much as possible. ${ }^{176}$ Solminihac's high regard for de Paul's opinion, and presumably for the advice of his other confidants, meant that he eventually followed this advice. It is also significant that Solminihac, later presented as a very Borromean prelate, changed his mind, and was prepared to temper his enthusiasm for Borromean austerity and extreme mortifying sacrifice when he felt it necessary: 'I will follow your advice in all; I had been resolved to expose myself only in so much as I knew it was the will of God.' ${ }^{177}$

The discussion that took place on this occasion between Solminihac and his associates is particularly interesting for its vivid portrayal of the issues which could and did arise in the development of ideas on episcopacy and reform. It is obvious that the questions of sacrifice and charity were particularly pertinent to reformers of the episcopate and that they received close attention in published texts and private reflections. It is also clear from this episode that, however much Solminihac's advisors admired Borromeo, they did not accept that he was an absolute or definitive example for bishops in all circumstances. Their general conclusion, to which Solminihac submitted, was that the charitable principle did not necessarily need to take the form of extreme physical suffering and mortification: it was as much a progressively 
cultivated mental and spiritual state as a corporal one, and love of God and one's flock could be shown in other ways.

Another reformer, Louis Tronson, offered the same advice to one of his episcopal confidants, by concentrating particularly on the primacy of interior spirituality over conventionally pious physical practices like fasting or vigils. Again and again, Tronson warned the bishop of Limoges, Lascaris d'Urfé, to avoid strict mortifications of the body: the bishop's propensity to restrict his rest and food as well as to push himself mercilessly in his work was not only dangerous to his physical health, but would ultimately affect his ability to pray and to perform the spiritual exercises which were the essential bases for the episcopal life. ${ }^{178}$ Tronson took the trouble to provide specific instructions for the bishop, including the suggestion that he should merely refrain from indulgent delicacies during his meal if he wished to perform an act of mortification. That seemingly small act would be 'at least as useful as other more brilliant penances', ${ }^{179}$ Neither Tronson nor de Paul, therefore, dismissed moderate habits of penance and austerity, but they were loath to counsel the kind of 'arduous' behaviour that would deliberately expose bishops to 'maladies' and even death. ${ }^{180} \mathrm{~A}$ 'long Lent' meant virtually nothing when compared with the virtuous disposition that formed true mortification of the heart. In fact, as Camus observed, it would demonstrate only 'half the virtue' of the interior spirit of charity, sacrifice and abnegation. ${ }^{181}$ Bishops should adopt equilibrial regimes of work, fasting and rest, leaving ample time to cultivate, through prayer and study, the charitable love that would drive their pastorates.

Salesian episcopacy was hardly an easy road to take but, importantly, it did allow some accommodation between the sacred and the profane in a society where the pressure on bishops to conform to secular values was particularly great, and from which they could not hope to escape even if they wished. Part of the attraction of this brand of episcopacy was the fact that bishops could assuage their consciences by adopting a stringent attitude to their spiritual life and by cultivating the internal spirits of poverty and charity, which compensated for a relatively relaxed exterior. For one of de Sales's greatest admirers, Bossuet, the temptations at court were acute: a man naturally inclined towards material sophistication, he maintained a comfortable, if not ostentatious, household as bishop, but fought to distance himself mentally from his worldly environment through hours of meditative prayer and study that aimed to draw him closer to God. ${ }^{182}$ Underpinning this activity was the Salesian dogma that though a bishop might be surrounded by wealth, he could cultivate the inner spirit of poverty appropriate to his office: 'Abandonment to God's will is a more efficacious means than all the extraordinary austerities ... the doctrine of Saint François de Sales appears very far from approving them. ${ }^{, 183}$ 
De Sales, then, obviously offered particular attractions to the French episcopate: first, an episcopal spirituality that could be cultivated by any bishop. This partially answers the question of why he was embraced so wholeheartedly by French authors and by French bishops themselves, as their repeated requests for his beatification reveal. Of course, this cult of the bishop fed into the process of beatification, for if those who agitated on his behalf could present him as a revered model of episcopal brilliance, then this would strengthen his case in Rome. Second, however, partially because of his links with the French reform school, this francophone bishop could be adopted as a truly French episcopal saint, born 'for the good of France' and for the specific benefit of its seventeenth-century bishops, even though he was not technically French. ${ }^{184}$ He offered the French what the Milanese, the Spanish and Portuguese churches had in Borromeo, Martyrs and Villeneuve, and so filled an acutely felt gap. In administration, therefore, he was the French Borromeo, but in his interpretation of episcopal virtue he was a seminal model, whom Caussin termed 'a domestic genius', like 'a mirror of perfection'. ${ }^{18}$

Even though, however, episcopal advisors removed self-inflicted physical suffering from their formula for episcopacy, they did not encourage a mellow life for bishops. Moderation of habits was the catchphrase in every treatise and manual, with virtually all authors identifying three particular dangers for contemporary bishops: first, the calls for favours made on them by relatives; second, the risk of becoming a crown servant rather than an ecclesiastic; and, finally, the temptation to spend diocesan income on frivolous luxuries. ${ }^{186}$ There was nothing worse than either a spendthrift, mercenary or politique prelate, and each was roundly condemned for his failure to distance himself literally and emotionally from material wealth and honour. Jean-Pierre Camus was one of the most outspoken, for as a bishop with quite a plain mode of living, he could not understand why other prelates presumed to use the church's goods as their own personal pot of gold. Riches and worldly honour meant absolutely nothing to a true bishop, so that he had no need for sumptuous clothing, food or fittings. The only way to honour the episcopal ministry was through virtue, which would ultimately earn the genuine respect of princes and paupers alike. ${ }^{187}$ Bishops were not courtesans who sold their integrity as God's ambassadors for earthly rewards and who allowed themselves to be tainted by politics, 'and possessed by this spirit that dominates at court'. ${ }^{188}$ Unfortunately, it seemed that for reformers too many bishops acted in just that way, so that their diabolically 'unregulated conduct' had nothing in common with the examples of Christ, his Apostles and Saint Paul. ${ }^{189}$ These were not true bishops, suggested Jean Le Noir, for not only did they fail to reside amongst their flock and attend to their pastoral cares; they lived scandalously debauched lives obsessed by the devilish perversions of lust, gambling or luxury. ${ }^{190}$ 
Equally, Godeau condemned the pomp that he believed to be destroying the episcopate. In particular, he argued that it was actually self-defeating, for if bishops acted like grands seigneurs, then the crown and laity were bound to treat them as such. If these were outwardly sycophantic, they inwardly scorned bishops for their profane 'concupiscence of the flesh'. ${ }^{191}$ With the same incisiveness, Godeau remarked that the seventeenth century predisposed bishops to extravagance, since they often felt obliged to follow the habits of the laity in order to avoid accusations of singularity and pride. He recommended that bishops adopt a way of living that struck a happy balance between decadence and exceptional frugality: simple eating habits, an avoidance of excessive sleeping and inactivity. Even the Assembly of Clergy issued guidelines on the simple life appropriate to a bishop, for 'that which is eminent before men is [an] abomination before God'. ${ }^{192}$

No one, however, condemned all material comfort. Rather, it was a question of using a degree of ornamentation and luxury which was consistent with the hierarchical dignity of the episcopal office. Yet no bishop should become a slave to secular and fleshly extravagances, since he should always be focused on God and on his spiritual charge. This was the stabilising 'poverty of the spirit', so apparent in the life and teaching of François de Sales, a complete emotional detachment from worldly surroundings. ${ }^{193}$ Of course, poverty is a relative concept in any century, but, in practice, it is obvious that a notable number of seventeenth-century bishops strove to combat the temptations of greed and immoderate consumption. Solminihac, Pavillon, Caulet, Hardivilliers and many other bishops were well known for their simple lives and their efforts to cultivate what they described as 'poverty of the body and soul'. ${ }^{194}$ Other bishops shared the same goal: a government official who visited Conserans in 1667 found a fine episcopal palace recently built by the hospitable Bishop Marmiesse, but recorded that the prelate actually lived routinely in plain chambers, 'without luxury or sumptuousness'. In this way, Marmiesse reconciled the public trappings of the episcopal office with the theological ideals of piety, temperance and humility. ${ }^{195}$

For every bishop famous for his moderate habits, there existed a comrade renowned for his conspicuous consumption and courtly lifestyle. How did prelates like Pierre de Marca and Anthime-Denis Cohon reconcile their extravagance with the ideal then pushed in every publication and personified in the lives of men like Solminihac? Some, of course, never tried to reconcile that contradiction; there is no evidence to suggest that the politique Pierre de Marca ever felt at all uncomfortable with the fruits of his role as advisor to the Mazarine government. ${ }^{196}$ But for some, like Bossuet, the stark discrepancies between indulgence and the contemporary episcopal vocational ideal simply became too disturbing to ignore and they had to find means of satisfying their consciences. 
The son of a mere candle merchant, the ambitious and resourceful Cohon climbed to episcopal status thanks to his prowess as a royal prédicateur under Louis XIII, and quickly became notorious for his love of wine, women and song. ${ }^{197}$ Not only did he indulge himself; he also coaxed bishops of a more austere turn to soften the demands which they made upon themselves: in 1638, he did not shy from urging the archbishop of Lyon, Alphonse Richelieu, to abandon his flock when plague overran the city. This advice was based purely on common sense, Cohon admitted, and a natural, rather than a moral, philosophy, that placed personal interests above any 'holy fury' or 'sentiment'. ${ }^{198}$

Cohon's persuasive effort was unsuccessful, for Richelieu resolutely refused to leave his see during this crisis. Yet before many years had passed, Cohon failed to follow his own advice: when his diocese (Nîmes) was threatened by plague, he remained in residence to bolster his clergy and to organise relief for the victims of plague. He was also a generous donator to charitable foundations, and has been identified as a conscientious Tridentine administrator, usually resident in Nîmes, and a regular convenor of synods and visitations. ${ }^{199}$ This was a complicated episcopate, therefore, in which an equally complex man of instinctively sybaritic tastes assuaged his conscience by making concerted efforts to temper elements of his life in accordance with the prevailing climate of episcopal reform. He might never reach the Spartan heights of men like Pavillon, Caulet or Pierre d'Hardivilliers of Bourges, but his was perhaps the workable, if flawed, variant that most bishops could realistically hope to achieve: an episcopate that compensated for particular frailties through superlative efforts in other aspects of the ideal presented in didactic works and by exemplary prelates. ${ }^{200}$

Even Fénelon found it difficult to avoid the trappings of a life at court, and it was not until he took up permanent residence in Cambrai, after his banishment from Versailles during the Quietest controversy, ${ }^{201}$ that he was free to indulge his taste for simplicity and frugality. ${ }^{202} \mathrm{He}$ was so appalled at the extravagances of some bishops that he was moved to write to Colbert, archbishop of Rouen, to complain of the 'building frenzy' sweeping France; how could this be curbed, he asked, if bishops did not give an example of simplicity and modesty in their living arrangements? 'Show the heart of a bishop', he urged, 'who is no longer tied to the world, and who brings the reign of Jesus Christ.' Instead, Fénelon saw in Colbert a disciple of Christ who had fallen prey to the deadly sins of pride and greed: 'The Gospel is in [your] mouth, and social glory is in [your] works. ${ }^{203}$ However, even in the career of a devout churchman like Fénelon, the tension between episcopal ideals of ecclesiastical service and secular temptation is evident; this bishop did not reside in Cambrai for the first two years of his appointment because Louis XIV requested that he continued to tutor the duke of Bourgogne at the royal court..$^{204}$ 
Given the imprint that non-French bishops made on the development of French episcopal ideals, it is not altogether surprising that no native bishops emerged to dominate hagiography. Probably the sheer supremacy of de Sales, and indeed of Borromeo, discouraged attempts to further the hagiography of contemporary French bishops. This does not imply that efforts were not made to promote the cult of individual members of the French episcopate. A number of hagiographic works dealing with French bishops were produced during this period, and we have referred to them during the course of this chapter. Those bishops were all well-known reformers: François de La Rochefoucauld, Donadieu, Cospeau, Solminihac, Gault, Villazel and Pavillon. Excepting Solminihac and La Rochefoucauld, all benefited from just one work each. Godeau also included Solminihac, along with Jean-Baptiste Gault, in his Éloge des évesques. These were, however, the only two of his contemporaries whom he felt to be deserving of his attention. ${ }^{20}$

Each of these bishops was a prominent prelate of his day, and, three years after his death in 1643, the Assembly actually suggested that Gault be canonised. ${ }^{206}$ Although, however, he was considered a 'saintly' bishop, the only two individuals who came close to a hagiographic tradition around their episcopates, even before their deaths, were Alain de Solminihac and Nicolas Pavillon. Contemporaries were fulsome in their praise of their administrations and personal characteristics; they were not regarded as wholly original in the character of their vocation but were considered to express fully the accepted French ideal of the bonus pastor. Solminihac's canonisation was raised in the Assembly of 1670, though not discussed at length, following an enquiry into his life and miracles under Nicolas Sévin. ${ }^{207}$ Even before he died in 1659, many who knew him regarded him as a saint: his friend Vincent de Paul remarked that, even in the midst of turmoil, he managed to maintain a spirit of inner peace. He was able to do so because he persistently kept his eyes fixed on God, striving to please him rather than men. De Paul concluded that the bishop's soul was intimately linked to the divine. ${ }^{208}$

Others commented favourably on Solminihac's untiring administration in Cahors and his personal virtue. When his admirers described these, they painted the bishop as a classic mixture of Borromean rigour and institutional genius and Salesian sacrifice and charity. Chastenet, his chief biographer, presented Solminihac as a zealous bishop motivated by the charitable impulse, patiently suffering hardship for love of flock and God, and persistently fulfilling his administrative duties until finally overtaken by terminal illness. ${ }^{209}$ Moreover, a number of bishops, like Salignac of Sarlat, Marmiesse and Vialart declared themselves heavily influenced by his example. According to Vialart, 'The memory of the late monsignor bishop of Cahors is in great benediction not only in France but even in the whole church, and all good people conserve great veneration for the examples 
which he left, of penitence, poverty, charity, untiring work in the functions of his charge. ${ }^{210}$ Solminihac's advice was sought on administrative matters by a number of bishops; Philibert de Brandon, a bishop particularly admired by Solminihac as an 'apostolic man', ${ }^{211}$ sought his counsel when he wished to establish a seminary in Périgueux shortly after the Mercuès conference. ${ }^{212}$

Pavillon was likewise credited with inspiring his fellow bishops. Besides his close links with Étienne Caulet, his advice was sought on administrative matters by prelates such as François Bosquet, Pierre Fenouillet, François Fouquet, Jerome de Grimaldi, Nicolas Sanguin and Felix Vialart. ${ }^{213}$ The bishop's virtue was also the subject of praise, both before and after his death in 1677; his charity, piety, doctrine and humility were all considered to be of superb quality and worthy of imitation. Antoine Godeau was highly impressed by Pavillon and expressed his hope of visiting the bishop of Alet 'to renew my interior, to open my heart to him, and to edify myself by his examples'. ${ }^{214}$ Pavillon's personal life was as simple as Solminihac's: each shunned luxurious furniture, clothing and food, spent two hours in prayer daily and devoted the bulk of his revenues to the poor. This was material simplicity, but also the 'poverty of the spirit', that detachment from worldly goods and values, so beloved of the French episcopal ideal. ${ }^{215}$

There were aspects of Pavillon's and Solminihac's episcopates with which other bishops were not entirely content. Étienne Le Camus certainly revered Pavillon, calling him 'a saint on earth', with 'a humility, a divine presence and a charity which delight me'. Even so, he was not absolutely comfortable with Pavillon's style and went on to add a single cautionary note to his assessment, discerning in the bishop of Alet that same characteristic that he identified in Caulet: 'He is inflexible when he believes that he sees his obligations clearly and he has a surprising condescension . . . it is terse and unlikely to convert all and he has no tolerance for the expedients and dispositions that are necessary.' Le Camus did not doubt that this approach had been successful in Alet because it had been adopted in proportion to the needs of the diocese, but he felt, for temperamental reasons, that he could not assume it himself in Grenoble. He would have preferred more tactful diplomacy in the bishop's intercourse, but, even so, he conceded that 'men have weaknesses whatever virtues they might have; I did not recognise any in [Pavillon]; it is a masculine piety, firm, uniform, charitable, always in order. ${ }^{216}$

There were those, chiefly clerics with whom Pavillon clashed in Alet, who accused the bishop of excessive austerity in his conduct, ${ }^{217}$ but it was, apparently, differences in personal taste and personality, rather than a profound clash of principles, which prevented Le Camus from wholeheartedly endorsing Pavillon's episcopate. Pavillon himself actually found Solminihac's style a little too rigorous for his liking, and Caulet commented that both had sometimes 
displayed too much rectitude in their discipline. ${ }^{218}$ In general, however, these were criticisms of the style rather than the substance of these bishops' tenures, and were a function of the individual personalities which made up the episcopate. The shrewd Godeau made precisely this point when he compared Solminihac with de Sales in 1665. A firm admirer of both bishops, he admitted that Solminihac's personality had made him seem more severe than the naturally temperate de Sales. For Godeau, Solminihac's instinctive rigour was a flaw in his otherwise excellent character, but he had managed to overcome it with a generosity of spirit that mirrored de Sales's charitable love. ${ }^{219}$ Yet many other bishops did not even complain that Pavillon or Solminihac had been too tactless or inflexible and, in fact, they admired their resolution through their long careers. Indeed, even when contemporaries occasionally criticised 'saintly' bishops, they invariably highlighted the fact that their natural character traits had not smothered that most crucial of episcopal qualities: charity. Like Godeau, Le Camus was careful to distinguish and approve Pavillon's selfless love of God and his flock, before praising his humility and dedicated leadership. This distinction explicitly identified charity as the superior virtue that bound de Sales, Solminihac and Pavillon, and it was this common quality that made them so special to their admirers.

The fact that Pavillon, Solminihac and several other French prelates were presented as personifications of an episcopal ideal that combined elements of the pastorates of Borromeo and de Sales and linked them to the bishops of the early church demonstrates the blending and reworking of traditions and ideas that took place in the evolution of seventeenth-century pastoral ideals, as well as in other aspects of episcopacy. De Sales brought charity particularly to the fore, and provided a more humane focus for the bureaucratic or legislative pastorate of the Borromean school, which French bishops did not consider to be adequate for their requirements or fully representative of the spiritual and pastoral role of prelates in the church. His spirituality obviously fulfilled an episcopal need, that of articulating an updated spiritual inspiration and framework for the complicated realities thrown up by bishops' administrative work and personal lives. For these men and those who advised them sought a workable pastoral ideal, one that was demanding but possible to apply, and they managed to formulate it by weaving together the ideas and lives of venerable prelates, past and present. No French prelate emerged as a dominant paragon during this period, but the composite model crafted from older traditions was thought to be admirably fulfilled by a number of celebrated bishops. Yet François de Sales towered above all these, adopted as a French example of episcopal brilliance, perfectly blending the Borromean administrative style with his own less austere ideas of interior mortification and charity. 
Notes

1 For the dramatic development of hagiographic scholarship outside France during this era, see Simon Ditchfield's study of Tridentine Italy: Liturgy, Sanctity and History in Tridentine Italy. Pietro Maria Campi and the Preservation of the Particular (Cambridge 1995).

2 Jean Baptiste Possevin, Discours de la vie de Sainct Charles Borromée cardinal du tiltre de Saincte Praxède, et archévesque de Milan, trans. A. C. (Bordeaux 1611); Jean-Pierre Giussano, Histoire de la vie, vertus, mort et miracles de Saint Charles Borromée, cardinal prêstre du titre de Saint Praxede, archévesque de Milan, trans. Nicolas de Soulfour (Paris 1615); Jean Lemarie, Abregé de la vie, miracles, et canonisation de S. Charles Borromée, cardinal du tiltre de Sancte Praxede, et archévesque de Milan (Saint-Malo 1618).

3 See, for example, Jean-Pierre Camus, Les Devoirs paroissiaux (Paris 1642); Jean-Pierre Camus, Les Emplois de l'ecclesiastique du clergé (Paris 1643).

4 Molinier, Donadieu, p. 8.

5 Noulleau, Villazel. Noulleau (1607-72) enjoyed excellent relations with Villazel, to whom he owed his position as diocesan théologal: Brémond, Histoire, vii, pp. 197-214.

6 Peter Burke, 'How to Become a Counter-Reformation Saint', in Kaspar von Greyerz (ed.), Religion and Society in Early Modern Europe (London 1984), pp. 45-55; Rudolph Bell and Donald Weinstein, Saints and Society. Christendom, 1000-1700 (Chicago and London 1982), p. 14.

7 See Ditchfield, Liturgy, pp. 273-360, for a detailed discussion of the local ecclesistical histories produced by Italian scholars during the seventeenth century.

8 Binet dedicated his L'Idée des bons prélats et la vie de Saint Savinian, primat et premier archévesque de Sens, et de ses saints compagnons (Paris 1629) to Bellegarde.

9 Étienne Binet, De la sainte hiérarchie de l'église, et de la vie de Sainct Aderald, archdiacre et chanoine de Troyes, restaurateur de la communauté des chanoines (Paris 1633), pp. 12-19: 'vicaires de Dieu . . . qui bruslent d'amour de Dieu, . . Image du Dieu vivant, son Lieutenant sous le ciel . . . Peut on rien conçevoir de plus eminent?'

10 Nicolas Lescalopier, Le Protecteur de la maison de Dieu. Contre l'impieté, et l'ambition (Paris 1636), p. 306: 'Quelle puissance a un père sur ses enfants, et quel respect et obéissance doivent les enfans à leur père; de quelque condition que soient les hommes, ils sont enfans des Évesques.'

11 The only detailed treatment of Noulleau's theology and spirituality is found in Brémond, Histoire, vii, pp. 214-65.

12 Noulleau, Villazel, pp. 12, 19-20.

13 Leonor d'Etampes, Advis de l'assemblée générale du clergé de France. À messieurs les archévesques et évesques de ce royaume (Paris 1625), pp. 5-9.

14 Ibid., p. 23.

15 Camus, Hiérarque, preface (unpaginated): 'remarqer ce que vous avez de bon pour en rendre grâces au Père des lumières, ... . et ce qui vous manque, afin que vous taschrez d'avoir cet or pur que l'ange dans l'Apocalypse conseille à un Évesque d'acheter afin de se rendre riche pour l'éternité.' The biblical reference is to Rev. 3:18.

16 Ibid., pp. 16, 18.

17 Ibid., pp. 111-12, 432.

18 Camus, Considérations, pp. 91-2.

19 Camus, Hiérarque, p. 237; Camus, Considérations, p. 64-5; Camus, Unite, p. 39.

20 Camus, Hiérarque, p. 649; Camus, Esprit, ii, p. 11.

21 Camus, Hiérarque, p. 140; Camus, Considérations, p. 151; Camus, Unite, pp. 94, 147.

22 BN, Ms. Fr. 14428(i).

$23 \mathrm{Ibid}$., fos 5v-7r: 'Nous sommes comme la victime qui doit estre immolée pour tous les peuples de nos dioceses, et nous en approcherons avec cet esprit de victime.'

24 Ibid., fos $66 \mathrm{r}-\mathrm{v}$.

25 Antoine Godeau, La Vie de S. Augustin évesque d'Hyponne (Paris 1652), p. 373: 'la Dignité la plus sainte qui soit en la terre, . . . la participation de toutes les grandeurs et de toute la puissance du Fils de Dieu'; Godeau, Lettres, p. 126, Godeau to Chappelain, 12 September 1639: 
'plus élevez au dessus du peuple par leurs vertus que par leur caractère'. Bishop Arnauld noted that the virtues of priesthood 'doivent se trouver dans un degré plus éminent dans les Pontifes de Jésus-Christ': quoted in Bonnot, Arnauld, p. 153.

26 Camus was consecrated bishop in 1609 and Etampes in 1621.

27 Ch. 2, pp. 59-65.

28 Camus, Hiérarque, pp. $94-5$.

29 Antoine Godeau, La Vie de Saint Charles Borromée, cardinal du titre de Sainte Praxede, et archévesque de Milan (Paris 1657), preface (unpaginated). This was reprinted in 1663 and 1684.

30 Ibid., preface (unpaginated), pp. 566-7.

31 Antoine Godeau, Éloge des évesques, qui dans tous les siècles de l'église ont fleury en doctrine et en sainteté (Paris 1665), pp. 735-7: 'Le plus haut degré de Grace en la terre est celuy de l'Episcopat; et le Père Gault en fut entiérement pénétré.'

32 Lefebvre, Pavillon, p. 274.

33 Isaac Le Maistre de Sacy, La Vie de Dom Barthélemy des Martyrs religieux de l'ordre de S. Dominique, archévesque de Brague en Portugal (Paris 1663), pp. 574-5. Two editions of this work appeared in 1663, followed by editions in 1664 and 1678. All were published in Paris.

34 François de Sales, Les Oeuvres du bienheureux François de Sales évesque et prince de Genève, 2 vols (Paris 1641), ii, p. 22.

35 Etampes, Advis, pp. 84-6, 105.

36 Godeau, Augustin, pp. 448-50: 'Les troupes de secours ne veulent point reçonnoistre les Chefs legitimes ... Que quand la soûmission est seulement en paroles et en révérences . . . on change le privilege de pouvoir servir en prétentions de commander.'

37 Godeau, Borromée, pp. 526-32.

38 Noulleau, Villazel, pp. 32-5: 'laisser à tous les Saints Évesques . . . la iurisdiction Épiscopale sur toutes les consciences de leurs Diocèses'.

39 Camus, Hiérarque, p. 83: 'Quant à l'institution de l'Épiscopat, qu' elle ne soit de droit divin, ie ne voi personne qui le contredire, non seulement quant à l’ ordre mais aussi quant à la Iurisdiction.'; Camus, Esprit, i. pp. 155-6.

40 Almeida Rolo, L'Evêque, p. 92.

41 Godeau, Évesques, pp. 571-2.

42 Alexandre-Louis Varet, Relation de ce qui s'est passé dans l'affaire de la Paix de l'église sous le pape Clément IX, 3 vols (n.p. 1706), ii, p. 383.

43 Noulleau, Villazel, p. 30.

44 Ch. 5, p. $144-62$.

45 Camus, Borromee, p. 31; Claude de La Chambre, Panégyrique de S. Charles Borromée cardinal et archévesque de Milan prononcé en l'église de Saint Jacques de la Boucherie (Paris 1670), p. 40.

46 Lemarie, Borromée, preface (unpaginated).

47 Binet, Idée, pp. 186-91: 'L'Evesché [est] un vray apprentissage du Martyre . . . passer le cousteau par la gorge, et verser tout nostre sang sur l'Autel preparé.' See also Camus, Hiérarque, p. 371.

48 Le Maistre, Barthélemy, pp. 597-8.

49 Godeau, Évesques, p. 588; Simplician Saint Martin, La Vie de S. Thomas de Villeneuve, dit l'aumosnier, de l'ordre des Hermites de S. Augustin, archévesque de Valence (Toulouse 1659), p. 99.

50 Antoine Godeau, Éloge historique du bienheureux François de Sales, évesque et prince de Genève (Paris 1663), pp. 150-3.

51 Camus, Hiérarque, pp. 87-8: 'Quoi que les Évesques soient attachez à la garde de certains limites, que l'on appelle Diocèse ... . ils ne perdent pas pourtant le soin de l'Église en général, au bien de laquelle ils doivent travailler de toutes leurs forces.'

52 Ibid., pp. 89-90, 447.

53 Noulleau, Villazel, pp. 31, 50.

54 Sales, Oeuvres du bienheureux François, ii, p. 25: 'le Pasteur non seulement d'un peuple et d'un paîs, mais le Père commun de tous les peuples, et de tous les paîs . . . le chef, l'oeil, le coeur, et la main du monde, et de l'Église'. 
55 Godeau, Augustin, p. 406.

56 Godeau, Borromée, p. 572.

57 Godeau, De Sales, p. 118.

58 Godeau, Évesques, p. 570.

59 Godeau, Discours sur les ordres sacréz, où toutes les cérémonies de l'ordination selon le pontifical romain sont expliquées (Paris 1653); Godeau, Traité des séminaires (Aix 1660).

60 Marc Fumaroli, L’Âge de l'éloquence (Geneva 1980); Bruno Neveu, Religion et érudition aux xvii et xviii siècles (Paris 1994), p. 336.

61 Saint Martin, Villeneuve, p. 99.

62 Claude Morel, La Conduite de Saint Augustin contre les Pelagiens, suivie par les evesques de France contre les Jansenistes (Paris 1658), p. 8.

63 The early church bishops were Savinian of Sens, Fulcran of Lodève and Augustine of Hippo. Hagiographic works on contemporary French bishops were produced on Philippe Cospeau (one), Barthélemy Donadieu de Griet (one), Jean-Baptiste Gault (one), François de La Rochefoucauld (two), Nicolas Pavillon (one), Alain de Solminihac (three) and Étienne Villazel (one).

64 Louis Abelly, Episcopalis sollicitudinis enchiridion ex plurimorum ecclesiae catholicae antistitum sanctitate, ac pastorali vigilantia insignium, et praesertim D. Caroli Borromaei S. R. E. C., archiep. Mediolan. theoria et praxi accurate collectum, complectens summatius omnia (Paris 1668), p. 11; Camus, Hiérarque, pp. 148-51, 226; Réné Le Mee, Le prélat accomply, répresenté en la personne d'illustrissime seigneur Philippe Cospéan, évesque et comte de Lisieux (Saumur 1647), pp. 205-6; Molinier, Donadieu, p. 165; Noulleau, Villazel, pp. 17-18; de Paul, Correspondance, ii, p. 625, Solminihac to de Paul, 31 July 1646.

65 Camus, Hiérarque, pp. 74-81.

66 Lettre de l'assemblée generale du clergé de France: au pape Urbain VIII sur la desirée beatification de feu Mr. de Sales, evesque de Genéve, trans. Pelletier (n.p. 1625); Procès-verbaux, ii, pp. 70-6, 187; ibid., iii, pp. 37, 91; ibid., iv, p. 131. The process for de Sales's canonisation opened in 1627. He was beatified in 1662, and canonised three years later.

67 Camus, Esprit, i, pp. 21, 73; ibid., ii, pp. 66, 90; ibid., iii, p. 32; Étienne Cavet, Pourtraicts racourcis de Sainct Charles Borromée, Saincte Thérèse, Soeur Marie de l'Incarnation, et du B. H. François de Sales, évesque de Genève (Lyon 1632), p. 278; Godeau, De Sales, p. 78; Sales, Oeuvres du bienheureux François, ii, pp. 47, 51.

68 Molinier, Donadieu, pp. 275-85.

69 Camus, Hiérarque, p. 317: 'Que si tous les Chréstiens sont appellez une nation saincte, combien plus saincts doivent êstre ceux qui les gouvernent au spirituel.'; Etampes, Advis, p. 7.

70 Camus, Hiérarque, p. 320: 'autant qu'il est possible à l'humaine fragilité la copie à son prototype . . . Jésus-Christ.'; Le Mee, Cospéan, pp. 10, 17.

71 Le Maistre, Barthélemy, p. 543: 'Que soit tellement adonné à l'oraison, qu'il sçache désja par expérience qu'il pourra obtenir de Dieu ce qu'il luy demande.' See also Jean Le Noir, L'Evesque de cour oppose a l'evesque apostolique. Second entretien (n.p. 1674), p. 124.

72 Olier, Lettres de M. Olier, ii, p. 520, Olier to unnamed correspondent, (n.d.); Camus, Hiérarque, p. 52; Camus, Esprit, ii, pp. 288-93.

73 Claude Maubourg, Éloge historique, ou la vie de Saint Thomas de Villeneuve, religieux de l'ordre de Saint Augustin, archévesque de Valence, surnommé l'aumônier (Paris 1666), p. 111.

74 Camus, Borromee, pp. 10-15.

75 Godeau, Augustin, p. 496; Maubourg, Villeneuve, p. 114.

76 BN, Ms. Fr. 14428(i), fos 3v, 40v.

77 Quoted in Sol, Solminihac, p. 96: 'Je seray fort réservé à parler de moy . . . je m'abstiendray de tous discours qui pourroient tourner à notre louange . . . Je ne parleray point des fautes des autres, si je n'y suis obligé . . . L'humilité et la douceur seront mes deux chères vertus.'

78 Solminihac, Lettres, ed. Sol, pp. 137-8, letter to Louis XIII, June 1636. Solminihac had previously refused the bishopric of Lavaur for the same reasons: ibid., p. 135, letter to Richelieu, 20 April 1636; ibid., letter to François de Sourdis, same date; ibid., p. 136, letter to 
Jean Barrault (bishop of Bazas), same date. Godeau rejected accusations that he sought a bishopric for personal advancement: Godeau, Lettres, pp. 132-3, Godeau to Richelieu, (n.d.).

79 Quoted in Raymond Darricau, Au coeur de l'histoire du Quercy. Alain de Solminihac érêque de Cahors (1593-1659) (Chambray-lès-Tours 1980), pp. 24-5; quoted in Sol, Solminihac, p. 96: 'Nos discours seront le plus que nous pourrons de choses spirituelles et de ce qui me pourra enflammer . . . à l'amour de Dieu . . . me tenant toujours en la présence de Dieu . . . je ne veux avoir autre volonté que celle de mon Dieu, et de ne faire aucune action que je ne me sente meu d'icelle.'

80 Solinihac, Lettres, ed. Sol, pp. 80-1, Barrault to Solminihac, 12 March 1629.

81 Chastenet, Solminihac, p. 758.

82 Abelly, Episcopalis, pp. 289-91, quoting Heb. 6:12; Camus, Hiérarque, pp. 190, 256-61, 270-1; Saint Martin, Villeneuve, p. 91.

83 Camus, Esprit, ii, p. 91; Le Mee, Cospéan, p. 129.

84 BN, Ms. Fr. 14428(i), fo. 9v; Godeau, Évesques, p. 752; Jean Le Noir, L'Evesque de cour, opposé a l'evesque apostolique. Quatrième entretien (Cologne 1675), pp. 132-5, 150-3.

85 BN, Ms. Fr. 14428(i), fo. 53r; Camus, Hiérarque, pp. 188-9; Godeau, Augustin, pp. 401, 421, 426-7; Symphorien Guyon, Histoire de l'église et diocèse, ville, et université d'Orléans, 2 vols (Orleans 1647-50), ii, p. 491; Noulleau, Villazel, p. 30.

86 Darricau, Coeur, pp. 35-6; Jacques, Cospeau, pp. 97-9; Taveneaux, Jansénisme, p. 59; Jean de Viguerie, 'Les Evêques d'Angers et la réforme catholique (1540-1758)', L'Evêque dans l'histoire de l'église (Angers 1984), pp. 91-108. See Bergin, Episcopate, pp. 110-12, 114, for lists of episcopal revenues.

87 Documents sur M. de Caulet évêque de Pamiers et sur le schisme de la régale dans ce diocèse, ed. JeanMarie Vidal (Castillon-en-Couserans 1936), pp. 9-14; Extension, ed. Dubruel, pp. 30-5, Le Camus to Caulet, 21 August 1679.

88 Le Sauvage's will is printed in M. Fougeray du Coudrey, 'René Le Sauvage évêque de Lavaur 1630-1677', Extrait du Bulletin du Pays de Granville (1909), 33-5; Darricau, Coeur, p. 52; Jean Jenny, 'Un archevêque réformateur: Pierre d'Hardivilliers, archévêque de Bourges (1639-1649)', Bulletin de la Sociéte d'Emulation du Bourbonnais (1971), 608.

89 E. K. Sanders, Fénelon. His Friends and his Enemies 1651-1715 (London 1901), pp. 418-20; 'Documents inédits', ed. Philippe Tamizey de Larroque, Revue de Gascogne, 8 (1867), 91-6.

90 Darricau, Coeur, p. 52; Testament de feu monseigneur l'evesque de Ballay, touchant sa sepulture (Paris 1652).

91 Camus, Esprit, ii, p. 159; Chastenet, Solminihac, p. 758; Sales, Oeuvres du bienheureux François, ii, p. 23.

92 Godeau, Lettres, pp. 127-31, letter to Chappelain, 12 September 1639: 'qu'on les charge d'injures, que l'on donne un mauvais sens à leurs actions les plus innocentes, qu'on leur dresse des pieges, qu'on se mocque de leurs remonstrances, et qu'on les persecute.' See also Godeau, Borromée, pp. 361-3.

93 Godeau, Borromée, preface (unpaginated).

94 Godeau, Lettres, p. 129, Godeau to Chappelain, 12 September 1639.

95 Camus, Borromee, p. 38; Godeau, De Sales, p. 96; Henri Cauchon de Maupas Du Tour, La Vie du vénérable serviteur de Dieu François de Sales (Paris 1657), p. 16.

96 Etampes, Advis, p. 42; Godeau, Lettres, pp. 124-31, letter to Chappelain, 12 September 1639; ibid., pp. 132-3, letter to Richelieu, (n.d.).

97 Ibid., p. 132, letter to Richelieu (n.d.).

98 Ibid., pp. 359-61, letter to Abbé de Cerisy (n.d.); Camus, Esprit, iii, p. 230.

99 Godeau, Évesques, pp. 757-9.

100 De Paul, Correspondance, iv, pp. 145-7, Solminihac to de Paul, 25 January 1651; ibid., p. 154, de Paul to Solminihac, 18 February 1651; ibid., pp. 219-20, Solminihac to de Paul, 2 July 1651; ibid., pp. 634 -5, Solminihac to Anne of Austria, same date.

101 Camus, Hiérarque, p. 386; Godeau, Évesques, p. 735; Molinier, Donadieu, p. 193. 
102 De Paul, Correspondance, ii, p. 389, Solminihac to de Paul, 3 May 1643; ibid., pp. 624-5, same to same, 31 July 1646.

103 Solminihac, Lettres, pp. 575-6, Solminihac to Villers la Faye, 5 November 1654.

104 Camus, Hiérarque, p. 386.

105 Etampes, Advis, pp. 50, 65, 118; Jean-Marie de La Mure, Histoire ecclésiastique du diocèse de Lyon (Lyon 1671), pp. 214-17.

106 Abelly, Episcopalis, pp. 130-60; Le Maistre, Barthélemy, p. 574: 'L'Évesque communique sa présence et sa charité à tout le corps de son Diocèse, et qu'il répand les graces et les bénédictions du Ciel sur tous ceux qui en sont les membres.'

107 Godeau, Évesques, p. 569; Le Maistre, Barthélemy, pp. 574-5; Saint Martin, Villeneuve, pp. 90-3.

108 Bibliothèque de l'Arsénal, Ms. 6042, fos 363r-366v: 'Je scay que selon l'Evangile, l'Evesque est la lumiere qui doit eclairer toute l'Eglise; selon St. Paul il est le pere qui doit instruire ses enfans.'

109 Camus, Borromee, pp. 144 -57; Camus, Hiérarque, p. 376; Godeau, Augustin, p. 502. In Godeau's Évesques, every bishop was praised for his zeal in preaching; see Le Mee, Cospéan, p. 199, citing 1 Tim. 3:2 and Tit. 1:8.

110 Fumaroli, Eloquence, p. 140.

111 Camus, Borromee, pp. 144-57.

112 Godeau, Augustin, p. 502.

113 Godeau, De Sales, pp. 112-14.

114 Camus, Hiérarque, preface (unpaginated). In his Borromean homilies, Camus again used this metaphor for bishops but also described the divine word as salt which bishops used to season and preserve souls: Camus, Borromee, p. 136; Godeau, Évesques, p. 560; Le Maistre, Barthélemy, preface (unpaginated); Sales, Oeuvres du bienheureux François, ii, p. 44. Guyon, Histoire, i, preface (unpaginated), characterises the 112 bishops of Orléans as the 'salt of the earth'. Antoine Arnauld also used this traditional phrase to describe prelates: Arnauld, Oeuvres, xxi, p. 207.

115 BN, Ms. Fr. 14428(i), fo. 144v.

116 Bergin, Episcopate, pp. 280-1.

117 Camus, Borromee, p. 158; Camus, Hiérarque, pp. 236-7.

118 BN, Ms. Fr. 14428(i), fos 7v-8r; Etampes, Advis, p. 29; Godeau, Augustin, pp. 513-14; Godeau, De Sales, pp. 111-12; Le Mee, Cospéan, p. 199; Pierre Nicole, L'Idée d'un évêque qui cherche la verité (n.p. 1666), p. 7.

119 BN, Ms. Fr. 14428(i), fos 3v-4r: 'un grand detachement de toutes choses, un aneantissement de nous mesmes, une profonde humilité, une grande patience . . . s'abandonnans aux mouvemens qu'il plaira a Dieu nous donner, et a tout ce qu'il voudra faire de nous.'

120 Sol, Solminihac, pp. 95-6; BN, Ms. 14428(i), fos 8v, 138r-v. Solminihac and Pavillon practised all three types of prayer. Scripture, the Council of Trent and the lives of bishops were the most popular recommendations for meditation and contemplation.

121 BN, Ms. Fr. 14428(i), fo. 8r.

122 Camus, Hiérarque, pp. 248-9; Godeau, De Sales, pp. 85-6; Le Maistre, Barthélemy, p. 556.

123 BN, Ms. Fr. 14428(i), fo. 138r-v; Sol, Solminihac, p. 95. See also Documents, ed. Vidal, p. 9, for Caulet's habit of frequent prayer.

124 Saint Martin, Villeneuve, preface (unpaginated).

125 François de Sales, Introduction à la vie dévote (Arras 1610) (2nd edn Paris 1641); François de Sales, Traicté de l'amour de Dieu (Lyon 1616); François de Sales, Les Oeuvres de Messire François de Sales evêque et prince de Genève (Toulouse 1637); Sales, Oeuvres du bienheureux François.

126 Jean-Jacques Olier, Oeuvres complètes de M. Olier, ed. Jacques-Paul Migne (Paris 1856), col. 1255.

127 Cavet, Pourtraicts, p. 431.

128 Maupas du Tour, De Sales, p. 25. Maupas was successively bishop of Le Puy (1643-61) and Evreux (1661-80): Bergin, Episcopate, pp. 668-9. 
129 Cavet, Pourtraicts, p. 432.

130 Broutin, Réforme, i, pp. 73-95; Paul Broutin, 'Les Deux grands évêques de la réforme catholique', Nouvelle Revue Théologique, 75 (1953), 282-99, 380-98.

131 Lemarie, Borromée, preface (unpaginated).

132 A further edition appeared in 1683: Venard, 'Influence'.

133 Bibliothèque Sainte-Geneviève, Paris, Ms. 2131, fos 2, 4, 14; Godeau, Lettres, p. 432, Godeau to Thomassin, 29 October 1671; Solminihac Lettres, ed. Sol, p. 380, Sevin to Solminihac, 19 November 1648.

134 Ibid., pp. 211, 215-16, 219; Documents, ed. Vidal, p. 9; Dejean, Pavillon, pp. 47-9; P. Dumoulin, 'Les Visites pastorales d'Alain de Solminihac', in Pierre Pommaréde (ed.), Alain de Solminihac (Périgueux 1993), pp. 18-29; Peyrous, Réforme i, p. 200; Vidal, Caulet, pp. 114-23.

135 Solminihac, Lettres, p. 380, Sevin to Solminihac, 19 November 1648.

136 BN, Ms. Fr. 14428(i), fos 19v-25r, 30r-31r; Bonnot, Arnauld, pp. 197-227; Gaillard, Choart, pp. 47-9; Dumoulin, 'Visites'.

137 These were district congregations of parish priests, established for the purposes of discipline, education and support. See BN, Ms. Fr. 14428(i), fo. 145r; Solminihac, Lettres, p. 47, Solminihac to Buzenval, c.1652; Relation de ce qui se faict dans le diocese de Cahors, par monseigneur l'illustrissime et reverendissime evesque dudit lieu, pour remettre la discipline ecclesiastique dedans son clergé, et les devoirs de la vie chrestienne dedans son peuple (Paris 1640), p. 2.

138 Peyrous, Réforme, i, pp. 120-4.

139 Peyrous, 'Réforme', 16, 23.

140 'Documents', ed. Ducaunnes-Duval, 481; Peyrous, 'Réforme', 19-22.

141 Ravenez, Sourdis, p. 219.

142 The text became required reading for many parish priests and seminary students: Marcel Bernos, 'Saint Charles Borromée et ses "Instructions aux confesseurs". Une lecture rigoriste par le clergé français ( $\mathrm{xvi}^{\mathrm{e}}-\mathrm{xix}^{\mathrm{e}}$ siècle)', Pratiques de la confession (Paris 1983), pp. 185-200; Bernard Plongeron, 'Charles Borromée, exemple et modèle: son influence en France (xvi -xix ${ }^{\mathrm{e}}$ siècles)', San Carlo e il suo tempo (Rome 1986), pp. 493-525.

143 Paolo Prodi, 'The Application of the Tridentine Decrees. The Organisation of the Diocese of Bologna during the Episcopate of Cardinal Gabriele Paleotti', in Eric Cochrane (ed.), The Late Italian Renaissance, 1525-1630 (London 1970), p. 229n; Anthony Wright, The CounterReformation: Catholic Europe and the Non-Christian World (London 1982), p. 218.

144 Logan, Venetian Clergy, pp. 250-1.

145 In a letter to the queen mother, Bérulle also highlighted Borromeo's admirable sacifices of austerity and humility: Bérulle Correspondance, i, pp. 210-14, letter to the queen mother, 3 November 1615.

146 Camus, Borromee, pp. 14-28.

147 Cavet, Pourtraicts, pp. 42-6.

148 Camus, Hiérarque, pp. 188-9: 'Nous ne sommes plus que les froides cendres dont nos predecesseurs estoient les charbons ardans.'

149 Jean-Jacques Olier, Discours sur Saint François de Sales, printed in Olier, Oeuvres complètes, cols 1253-72.

150 Godeau, Borromée, pp. 587-92: 'La vie de Saint Charles n'est pas un exemple regulier que tous les Evesques doivent suivre.'

151 Ibid., pp. 581-4.

152 Godeau, Augustin, pp. 568-75.

153 Camus, Esprit, iii, pp. 307-8, 337-9; Godeau, De Sales, pp. 94 6. Étienne Cavet supported this view of de Sales's 'temperate' sobriety: Cavet, Pourtraicts, pp. 312-17.

154 Olier, Oeuvres complètes, cols 1268-72.

155 Nicolas Caussin, Traicte de la conduite spirituelle selon l'esprit du B. François de Sales, evesque de Geneve, printed in Sales, Oeuvres du bienheureux François, ii, pp. 48-9. Camus concurred: Camus, Esprit, ii, pp. 254-5. 
156 Caussin, Traicte, in Sales, Oeuvres du bienheureux François, ii, pp. 52, 121.

157 Camus, Esprit, ii, p. 295; ibid., iii, pp. 237-9, 483.

158 De Paul Correspondance, ii, pp. 3-4, letter to Abelly, 14 January 1640.

159 Olier, Quatre, ed. Blazy, p. 15, letter to Caulet, January 1648, quoting 1 Peter 1:7.

160 Olier, Lettres de M. Olier, ii, p. 520, letter to one of the disciples of Saint-Sulpice.

161 Olier, Oeuvres complètes, cols 1266, 1269.

162 Sales, Oeuvres du bienheureux François, ii, p. 49.

163 Godeau, Borromée, pp. 581-92; Godeaux, Évesques, ii, p. 755.

164 Binet, Idée, pp. 7-11. Antoine Godeau lauded several 'martyr bishops', including Timothy and John Fisher, in his Évesques.

165 Binet, Idée, p. 53.

166 Ibid., p. 60.

167 Ibid., pp. 85, 219.

168 Ibid., p. 170: 'C' est la vertu qui parle par ces bouches de sang, et nul ne peut resister à la Rhetorique . . . de la patience magnanime, et invincible d'un vray serviteur de Jesus-Christ.'

169 Caroline Walker Bynum, Holy Feast and Holy Fast. The Religious Significance of Food to Medieval Women (Berkeley, Los Angeles and London 1987), p. 42; Bell and Weinstein, Saints, pp. 154-6, 233-4.

170 Le Maistre, Barthélemy, pp. 677-8.

171 Gaillard, Choart, pp. 5, 37.

172 Olier, Oeuvres oratoires, iv, pp. 327-8.

173 Ibid., pp. 335-9: 'Jamais homme n'a mieux pratiqué cette ruse innocente et cette salutaire intelligence, que le saint évêque dont nous parlons.'

174 De Paul, Correspondance, ed. Coste, viii, pp. 94-5, de Paul to Fouquet, 29 August 1659.

175 Ibid., iv, pp. 495-6, Solminihac to de Paul, 17 October 1652.

176 Ibid., pp. 520-2, de Paul to Solminihac, November 1652.

177 Ibid., p. 528, Solminihac to de Paul, 21 November 1652: 'Je suivray vos avis en tout, je ne m'estois resolu de m'exposer qu'en tant que je onnus que c'estoit la volonté de Dieu.'

178 Tronson, Correspondance, ii, pp. 398-9, letter to Lascaris d'Urfé, 27 June 1677; ibid., p. 429, same to same, 22 October 1678.

179 Ibid., pp. 434-5, letter to Lascaris d'Urfé, 23 December 1679: 'Pour le manger, il me semble que les mortifications de retrancher à chaque repas quelque morceau de bon goût, de ne rien manger de trop délicat dans les festins, de s'abstenir de mille petites friandises, etc., vous seroit au moins aussi utiles que d'autres pénitences de plus d'éclat.' See also pp. 443-5, same to same, 15 June 1680.

180 Ibid., pp. 423-4, same to same, 21 January 1679.

181 Ibid., p. 434, same to same, 23 December 1679; Camus, Esprit, iii, pp. 192-3, 372, 435.

182 J. Calvet, Bossuet. L'homme et l'oeuvre (Paris 1941), pp. 66-7.

183 Bossuet, Correspondance, vi, p. 421, letter to Madame Corneau, 10 October 1694: 'L'abandon à la volonté de Dieu et un moyen plus efficace que toutes les austérités extraordinaires . . . la doctrine de saint François de Sales . . . paraît très éloigné de les approuver.' See also François de Sales, Introduction to the Devout Life, trans. John Ryan (New York 1989), pp. 43-5.

184 Nicolas Talon's judgement in Sales Oeuvres du bienheureux François, ii, p. 20.

185 Ibid., p. 121.

186 Diocesan revenues varied enormously from the huge incomes of Paris, Toulouse and Rouen to the eight dioceses worth less than 5,000 livres during the seventeenth century. The majority of dioceses produced revenues of 10,000 to 15,000 livres annually: Bergin, Episcopate, pp. 110-15.

187 Camus, Hiérarque, pp. 158-9, 189, 225-30, 370-1, 667-8; Camus, Esprit, ii, p. 90; ibid., iii, p. 121; Jean Le Noir, L'Evesque de cour opposé a l'evesque apostolique. Premièr entretien sur l'ordonnance de monsieur l'evesque d'Amiens. Contre la traduction du Nouveau Testament en françois, imprimé à Mons (Cologne 1674), pp. 15, 21. 
188 Camus, Hiérarque, pp. 555-6; Jean Le Noir, L'Evesque de cour, opposé a l'evesque apostolique. Troisième entretien (Cologne 1675), p. 155.

189 Le Noir, Evesque. Premièr, p. 46; Le Noir, Evesque. Troisième, p. 155.

190 Le Noir, Evesque. Quatrième, pp. 137-45.

191 Camus, Borromee, pp. 7, 18; Camus, Hiérarque, pp. 182-3; Godeau, Borromée, p. 519; Molinier, Donadieu, p. 322; Noulleau, Villazel, p. 22; Saint Martin, Villeneuve, p. 82.

192 Etampes, Advis, pp. 30, 35-40: 'Ce qui est eminent devant les hommes, est en abomination devant Dieu.'

193 De Sales, Introduction to the Devout Life, pp. 161-9; Godeau, Augustin, pp. 420-6, 557-60; Godeau, Évesques, pp. 565; Le Noir, Evesque. Second, p. 168; Le Noir, Evesque. Quatrième, p. 144.

194 Autre relation plus recente et plus ample du progrez dont il plaist à Dieu de benir les soings et travaux de mondit seigneur l'illustrissime et reverendissime evesque de Cahors (n.p. n.d), pp. 1-4; BN, Ms. Fr. 14428(i), fos 3v, 9v-10r, 133v, 136v.

195 Personal belongings remaining at the bishop's death were bequeathed to the poor. The diocese's annual income at the time was approximately 14,000 livres: Henri Bégouen, Les Couserans aux xviie et xviiie siècles (Foix 1901), pp. 3-14; Bergin, Episcopate, p. 110.

196 Gaquère, Marca. Bergin estimates that the revenues of Conserans and Toulouse amounted annually to 18,000 livres and 53,000 livres respectively under Marca's tenures. Both were amongst the wealthiest dioceses in France: Bergin, Episcopate, pp. 110, 112.

197 The only biographical studies of Cohon are: the out-dated Charles Robert, Anthyme-Denis Cohon (Rennes 1895); François Duine, Un politique et orateur au XVII siecle, Cohon, évêque de Nîmes et de Dol. Essai de bio-bibliographie avec documents inédits (Rennes 1902); François Duine, Avant Bossuet. Cohon évêque de Nîmes et de Dol. Précepteur des neveux de Mazarin. Prédicateur du roi (Paris 1908). Sauzet's Contre-réforme also includes a discussion of Cohon's episcopate, pp. $216-44$.

198 Nouveaux manuscrits de Cohon, évêque de Nîmes, ed. M. Bligny-Bondurand (Paris 1910), pp. 17-18.

199 Sauzet, Contre-réforme, pp. 311-19.

200 Like several other bishops, including Le Sauvage and Marmiesse, Hardivilliers lived in just one room of his archepiscopal palace and left all his worldly goods to the poor and the church. On Hardivilliers, see Jenny, 'Hardivilliers'. On Le Sauvage, see Fougeray du Coudrey, 'Le Sauvage'. On Marmiesse, see Bégouen, Couserans, pp. 14-15.

201 Louis XIV considered Fénelon's Explication de maximes des saintes sur la vie interieure (Paris 1697) to be too close in doctrine to the mysticism (Quietism) of Jeanne de Guyon. Fénelon submitted to the papal condemnation of his semi-Quietist work in 1699. On the Quietist controversy, see Jean-Robert Armogathe, Le Quiétisme (Paris 1973), and Ély Carcassonne, Fénelon. L'homme et l'oeuvre (Paris 1946), pp. 25-74.

202 Carcassonne, Fénelon, pp. 139-40; Sanders, Fénelon, pp. 244 -8, 323-6. See also the remarks by Saint-Simon (generally not the most sympathetic of commentators) on the archbishop's strict daily routine of prayer and administration and his simple eating habits in Louis de Rouvroy, duc de Saint-Simon, Écrits inedits de Saint-Simon, ed. M. P. Faugère, 8 vols (Paris 1880-93), iv, p. 461.

203 Fénelon, Correspondance, ii, pp. 242-3, Fénelon to Colbert, 8 April 1692: 'L’Evangile est dans [votre] bouche, et la gloire mondaine est dans [vos] ouvrages . . montrez un coeur d'évêque qui ne tient plus au monde, et qui fait régner J. C.'

204 Fénelon resided in Cambrai from August 1697: Carcassonne, Fénelon, pp. 59, 139.

205 Godeau, Évesques, pp. 730-61.

206 Ibid., p. 739.

207 Sol, Solminihac, p. 410.

208 De Paul, Correspondance, ed. Coste, ii, pp. 434-5, letter to unnamed bishop, between 1643 and 1652 .

209 Chastenet, Solminihac, pp. 475-763, especially pp. 583-92, 659-71, 718-30 and 758-61. 
210 Quoted in Sol, Solminihac, pp. 399-400: 'La mémoire de feu Monseigneur l'évesque de Cahors est en si grande bénédiction non seulement en France mais mêsme dans toute l'Église, et tous les gens de bien conservent une telle et si grande vénérations pour les exemples qu'il a laissés, de pénitence, de pauvreté, de charité, d'un travail infatigable dans les fonctions de sa charge.' See also Fénelon, Correspondance, i, pp. 48-9.

211 De Paul, Correspondance, ii, p. 344, Solminihac to de Paul, 22 July 1648.

212 Solminihac, Lettres, pp. 428-9, Brandon to Solminihac, 28 December 1650.

213 Letters from all to Pavillon cited in Gaillard, Choart, pp. 138-9, 142n-143n, 149; Lefebvre, Pavillon, i, p. 273.

214 Ibid., i, p. 274.

215 BN, Ms. Fr. 14428(i), fos 133r-147v; Sol, Solminihac, pp. 95-7. Witnesses confirmed that the bishops lived according to the practices outlined in their rules: Les Diocèses d'Alet et de Pamiers d'après une relation contemporaine, ed. Marc Dubruel (Foix 1913); Autre relation, pp. $1-4$.

216 Etienne Le Camus, Lettres du cardinal Le Camus, ed. P. Ingold (Paris 1892), p. 205, letter to Abbé de Pontchâteau, 1675: 'C'est un saint sur terre, c'est une humilité, une présence de Dieu et une charité qui me ravit. Il est inflexible quand il croit voir ses obligations clairement et il a une condescendance surprenante . . . elle est sèche et peu propre à convertir le monde et il n'a aucune ouverture pour les expédients et les tempéraments nécessaires . . . les hommes ont les faibles quelque vertueux qu'ils soient; je n'en ai reconnu aucun en lui, c'est une piété mâle, ferme, uniforme, charitable, toujours en règle.'

217 Barcos, Correspondance, p. 544.

218 Solminihac, Lettres, pp. 661-2, Caulet to Sevin, 5 January 1661.

219 Godeau, Évesques, pp. 755-6. 


\section{Conclusion}

If historians have tended to overlook the changes in the necessity and function of bishops within the early modern Catholic church, the same accusation cannot be levelled at those French bishops, theologians and reformers who belonged to it. The first seventy years of the seventeenth century witnessed the most creative phase of Catholic reform within the French church, with energetic efforts in clerical reform, the emergence of an influential school of spirituality and the foundation of new religious orders. That creativity also embraced the church's episcopate: first, the social and educational features which would characterise it through the remainder of the ancien régime were defined during these decades. Less known, however, is the fact that these years were formative for the episcopate, and indeed for the entire French church, in yet another manner. From a long-term perspective, it is obvious that these dynamic decades saw an unprecedented evolution in ideology and a veritable outpouring of views, old and new, on the status of bishops, the theological significance of their office and their duties and rights. Detailed arguments were elaborated on the sacramental nature of episcopacy, the position of bishops within the ecclesiastical hierarchy and the attendant privileges that this bestowed on them. Episcopal jurisdiction proved a particularly thorny question, with highly contradictory opinions offered on the exact nature and extent of this power. Likewise, sustained, occasionally agonised, reflection took place on the pastoral element of episcopacy, concentrating particularly on the possible features of a specifically episcopal spirituality and on the relationship between episcopal administration and pastoral care.

That the episcopate flourished, after its unsteady start to the Bourbon reign, was due in no small measure to the fact that it managed to use this debate to construct referential principles that stacked into a mature and conscious ideology of episcopal identity defining its status and behaviour within church and society. Traditional visions of the episcopal vocation did not offer seventeenthcentury bishops the kind of guidance that would resolve the formidable 
ambiguities of Tridentine government and hierarchy, the onerous complexities involved in devising appropriate theological and spiritual inspirations for their vocations, or the tensions between the sacred realm and a rising secular authority. The episcopate's impressive ability, therefore, to devise and defend its ideology does not simply reveal the trials, failures and achievements of its personal experience but, more expansively, actually throws light on the growing pains of early modern catholicism.

There was, of course, nothing new in the fact that French bishops and other churchmen felt the need to develop and express their conceptions of episcopacy during the seventeenth century; such reflection was a traditional element of the interplay between theology, canon law and ecclesiastical government. What was exceptional to this era, however, was the sheer range of the opinions expressed on all aspects of episcopacy. Previously, debates tended to focus on one particular feature of the office, as during the Great Schism, when the papal-episcopal relationship held the attention of contemporary churchmen. Certainly, no period before the seventeenth century had seen anything like the expression of views which took place within France during this era. In the later sixteenth century there had been practically no debate within the French church, since bishops were principally preoccupied with antiProtestant polemics and especially with their efforts to survive during the religious conflicts. In fact, those prelates who did seek to initiate reform during these troubled years simply adopted the ideas of non-French reformers.

The ending of the civil wars provides some explanation for why French ideas on episcopacy underwent a remarkable upturn during the 1600s. Bishops' energies were no longer monopolised by the Huguenot challenge and they were, therefore, free to devote more time to reform and to reflection on their role within the church and French society. But the more tranquil circumstances of post-war France cannot be deemed the sole or even the most important factor in this development. There were two fundamental reasons for the elaboration of episcopal ideals during this era: first, the vigorous reform currents present within the contemporary French church, which encouraged searching debate on the functions and character of the episcopal office, and, second, the eagerness of warring factions to elaborate and defend their opinions in the public domain.

Reform manifested itself in several ways throughout the Catholic church, all of them driven by a belief that reorganisation and renewal were essential if religion was to be restored to its former grandeur. In France, the seeds of this movement were sown in the final decades of the 1500s, but the first half of the following century proved to be the high point of reform initiatives that were realised in the work of individual dévots and in foundations like the Company of the Holy Sacrament. Like the laity and lower clergy, sections of the episcopate were touched by the questing spirit of reform which characterised the French 
church and which moved individuals and groups to implement the ideas and practices that would renew it. The Acarie circle's search for a closer spiritual relationship with God was just one expression of a wider phenomenon in French society, one in which Catholics sought to relate their everyday lives more closely to the divine. Seen in this light, the sustained concentration on the formation of an episcopal spirituality designed to direct prelates in their ministry was part of the wider reform impetus within France. Equally, the sense that ecclesiastical reform was an ever more urgent task prompted many bishops to seek and adopt the Tridentine administrative practices that would enable them to realise it within their dioceses. In turn, this disciplinary drive brought new questions, and even dissension, on the precise level of authority that prelates commanded over the clergy operating in those territories. The question of bishops' jurisdiction could prove crucial when pastoral visitations took place, as they regularly did in many French dioceses during this period, or when regulars pleaded privilege and challenged their bishop's right to supervise their sacramental activities.

The reform of the clergy is perhaps the area most identifiable with the French Catholic Reformation, and certainly it is a subject on which its instigators made significant and widely adopted contributions. While their primary interest was the improvement of standards among the lower clergy, their teachings could not but influence contemporary conceptions of episcopal authority and hierarchical status. Ideas on episcopacy were disseminated in both oral and written form, through informal conversation, oratory, correspondence and reflections as well as through published texts. Obviously, bishops like Camus and Godeau were in the best possible position to express their opinions on, for example, episcopal grace and droit divin, to their fellow bishops through personal exchanges as well as through their many published works. But the multiplicity of means to transmit ideas also favoured other churchmen, in particular those individuals who were not members of the episcopate but who had direct access to bishops. It was far easier for a popular and central figure like Vincent de Paul to impress his thinking on prelates than for a relatively unknown regular or curé to do so. He and reformers like Bérulle, Condren, Olier and Tronson were particularly well placed to communicate their views on the perfection of the episcopal state, its pre-eminent place within the ecclesiastical hierarchy, the existence of episcopal grace and the extensive authority of prelates, not only to the priests within their congregations but to the episcopate itself. Through informal contacts within their circle of religious associates and through formal publications their ideas passed rapidly into the episcopate to become standard elements of its self-identity. They were also quickly adopted by apologists of episcopacy among the lesser clergy, and by hagiographers like Jean-Baptiste Noulleau. The reformers' episcopal ideal was a pervasive 
influence on the French church, mainly because its channels of transmission were so far-reaching and so comprehensive.

The leaders of the French school, therefore, possessed an undeniable advantage in the diffusion of their ideas over other contemporary French episcopal theorists. This point touches on an important fact: the views of these reformers were absorbed so quickly by the episcopate partly because their message was one that bishops were only too willing to adopt. There was a natural correspondence between the aspirations of the episcopate and the ideas of the reformers which was very obviously lacking in the relations between bishops and either regulars or curés, both of whom limited episcopal jurisdiction in order to protect their own status. The reformers' reverence for episcopal authority, grace and perfection flattered the office and those who held it, enabling bishops and their apologists to defend episcopal authority and prestige with pride. This was a particularly pertinent contribution given the demoralised state of the episcopate at the beginning of the century, and its impact was to be felt quite early; the strong endorsements of the episcopate's perfection and authority during the early 1630s by the likes of Saint-Cyran, Hallier and Le Maistre all borrowed heavily from Bérulle, and were particularly welcomed by French bishops who felt the power and honour of their office to be under siege from French and English regulars during the Smith crisis. Moreover, within twenty years of this conflict they themselves moved to endorse explicitly the droit divin of episcopal jurisdiction, which their apologists had adopted in the Smith crisis. Once they did so, it was established as a fundamental element of their episcopal theology.

Neither the reformers nor the bishops whose aspirations they answered, however, had matters all their own way. Disputes over episcopal status had been virtually unknown in the sixteenth century, with the possible exception of the Protestant attacks on episcopacy itself. But from the 1620s onwards the history of the French episcopate and church is punctuated with a catalogue of controversies which brought contrasting theories of episcopacy into sharp relief in the arena of ecclesiastical politics. The reciprocity between ideas and events cannot be under-estimated, therefore: crises like the Smith and Formulary affairs caused protagonists to develop new viewpoints, as well as to refine those already held, and were absolutely essential to the development of the episcopate's own ideological identity. Even though, for instance, neither regulars nor curés, among the bishops' most vociferous critics, may have succeeded in convincing the episcopate to accept the force of their claims on episcopal authority and ecclesiastical hierarchy over the course of the century, their willingness to elaborate and defend their opinions in the public domain was a vital element in the bishops' decision to develop and expose their own ideals. Each faction perfectly realised the significance of their quarrels for their future and that of 
their church. Questions of episcopal jurisdiction and ecclesiastical hierarchy did not merely affect the episcopate's status; they also held dramatic repercussions for the depth of the lower clergy's liberty within dioceses and for their status within the church's governing hierarchy. It was logical enough, therefore, that the passion of those quarrels should have pushed the episcopate towards the point where it was willing, in the twelve articles of 1657 , to deny officially and unequivocally the contemporary claims which assumed the jurisdictional independence of curés and which ascribed only limited episcopal authority over them. Likewise, it was as a result of repeated regular denials, within dioceses and in the Smith crisis, of bishops' jurisdictional droit divin that the episcopate expressly confirmed this theory in these articles.

The perennially thorny question of who should sit in judgement on bishops is also an important example of the ways in which rival ideas interplayed with landmark events to inspire and fortify the episcopate's ideals. While the Bérullian reformers did not directly address the question of whether bishops were to be judged by their peers, they laid the groundwork by emphasising the innate dignity of the episcopal office and the wisdom that it conferred on its incumbents. But it was not until the papacy and crown were deemed to threaten that dignity, by refusing to accept the episcopal right of trial by peers, that French bishops developed a concerted justification of their privileges. While, therefore, the basic principles of episcopal privilege, both as a general concept and specifically in relation to judgement, were in place before the actual disputes erupted, these clashes provided the opportunities for the episcopate to clarify and define its position in the face of powerful opposition. Moreover, sustained resistance to the episcopate's view encouraged it to assume an increasingly hard-line stance in defence of its rights.

One particularly significant consequence of the episcopate's involvement in these conflicts was the growing prestige and authority claimed for the Assembly of Clergy. Its intervention and indeed its leadership in the incidents related to episcopal jurisdiction, judgements of faith and the trial of bishops from the 1620s onwards gradually enabled it to assume something like the status of a national council, the voice of an episcopate that progressively favoured the gallican doctrine of conciliarism. In the 1650s, the vexed issue of Jansenism forced the episcopate to consider at length the extent of bishops' rule in dioceses, a question that was already particularly pertinent to it in the context of its acrimonious relations with the regulars and the papacy. By then presenting the Assembly as a national council that spoke and acted on behalf of all French bishops, its deputies were able to reconcile the principle of episcopal droit divin with their willingness to undermine the diocesan government of individual bishops. Since the episcopal deputies spoke for the episcopate, the opinion of the majority had to be accepted by all bishops as well as by those 
clergy below them in ecclesiastical rank. That assumption was heavily based on an understanding of the episcopate as a united corps within the church, a collegial group with its own unique responsibilities and privileges.

Jansenism provided a context and reason for the increasing prominence of the role of bishops as judges of doctrinal questions, both as individuals and in unison. That episcopal responsibility was then perpetuated in the gallican assembly of 1682 and cemented in its four Articles. But this emphasis on the bishop's ability to judge matters of faith was also a direct function of the dissemination of distinctive ideas on episcopacy by prominent clerical reformers and thinkers, a point that again highlights the interplay of ideas with events in the evolution of ideals of episcopacy. Just before and during the early years of the Jansenist controversy, Olier had described the episcopal condition as one that involved qualities of kingship, leadership and paternity: bishops were the figures of greatest enlightenment and wisdom, bestowing these gifts upon those below them in hierarchical rank. That principle is quite apparent in the stand taken by both the Assembly prelates and their opponents, the Jansenist prelates, in the Formulary affair. Like the Jansenist bishops, those prelates who supported the Assembly's position believed the responsibilities of bishops to include judging spiritual matters, according to their hierarchical position of authority and wisdom. The Jansenist bishops attempted to fulfil this role within their dioceses, but their behaviour proved absolutely unsatisfactory to the Assembly deputies since, they believed, it permitted vacillation by theologically suspect clergy. They desperately sought to force the quartet of recalcitrant bishops to submit to the Assembly's doctrinal judgements, on the basis that all bishops were obliged to accept the decisions of those prelates who represented them in this national council.

There were several contrasting views on the jurisdictional and theological aspects of episcopacy within the French church during the seventeenth century, with the differences among Bérullian reformers, regulars, curés, the papacy, the state and the episcopate playing off one another in a way that caused bitter conflicts and polarisation within the church. Clearly, no universally shared vision emerged, to which all sections of the French church were able to adhere, although its bishops certainly held fast to a particular ideal of episcopacy which they considered to be definitive. It is not suggested here that complete ideological unity existed within the episcopate: this was not always the case, as the dispute between the Jansenist bishops and the Assembly deputies over the Formulary demonstrated. But the evidence indicates that certain views of episcopal hierarchy, jurisdiction, theology and spirituality came to dominate the episcopate and were absorbed by most bishops. That process occurred to such a significant extent that these beliefs became generally representative of 
episcopal ideals. The fact that bishops were increasingly theologically literate certainly facilitated this, for they understood nuanced canonical and theological arguments and were capable of formulating and defending their own claims. Moreover, education was bound to encourage them to reflect on the status of their office so that the supply of ideas from reformers, apologists and lower clergy found a ready audience in members of the episcopate, anxious to develop motivations, frameworks and goals for their ministries. Ideals on jurisdiction, theology and spirituality had practical implications for the activities of bishops, providing guidelines in disciplining clergy, in supervising religious beliefs and practice and in supporting administrative routines through meditation, prayer and reading.

Some key features of the bishops' ideal were accepted as essential elements of all episcopal ideologies during this period. Undoubtedly the greatest degree of unanimity occurred over the spiritual and pastoral features of episcopacy, with every contemporary contributor to the pool of discussion agreeing that the bishop should be inspired by a spiritual outlook proper to his vocation. The Borromean-Salesian synthesis was recommended as the perfect model for Catholic bishops in their personal lives, with many prelates consciously endeavouring to cultivate its characteristic charity, intense "poverty of spirit' and administrative efficiency. However, it is clear from this that Borromeo's influence on the French church was neither as complete nor as clearcut as has traditionally been assumed. He was not adopted wholesale as a model nor was he the sole important influence on bishops and the pastoral ideal. The 'Borromean prelate' so beloved of generations of historians of the seventeenth-century church really did not exist, for it is a laudatory and narrowly conceived title principally based on the ability of a hardworking bishop to introduce impressive Borromean administrative practices. So-called Borromeans like Solminihac, Godeau, Pavillon and Caulet were the products of a more sophisticated amalgam of episcopal archetypes than this. However, it is not unexpected to find that a sliding scale operated when bishops actually attempted to introduce elements of this ideal into their episcopates. Some, like Solminihac, Alphonse Richelieu and Lascaris d'Urfé, needed the guidance of their associates to temper their natural tendencies to overstretch themselves physically, while others, like Anthime-Denis Cohon, adopted a pragmatic approach that allowed them to fulfil some of the ideal's demands while falling short in others. But that flexibility was actually crucial to the acceptance of this construction as an ideal for the episcopal life because it offered bishops freedom, albeit circumscribed, to live in society, to maintain reasonably comfortable living standards and to participate in secular affairs should the occasion arise: in sum, it accommodated some of the demands that Bourbon society placed on its prelates. 
The inclusive French vision was designed to overcome what were felt to be the shortcomings of the late sixteenth-century tradition that had failed to link successfully administrative duties with an appropriate spirituality. Without needing to abandon all the material ease of French episcopal life, bishops were encouraged to strive for perfection in virtue, and to cultivate a charitable love of God and of their charges; through self-sacrifice, this affection would enable them to fulfil the duties of their administration - government and teaching in God's service. This conception of episcopal spirituality was based on the premise that prelates formed the first rank within the ecclesiastical hierarchy and that, therefore, they had a duty to act as the enlighteners of those below them through word and example. The particular emphasis that this ideal placed on teaching was undoubtedly a crucial factor in the growing episcopal concentration on preaching within dioceses, and is closely related to wider developments in religious eloquence within the French church. ${ }^{1}$ When the preaching patterns of bishops during the sixteenth and seventeenth centuries are compared, the contrast is startling: while the possibility of a prelate ascending the pulpit in the 1500s was sufficient to draw throngs of curious (and amazed) listeners, it was a commonplace less than one hundred years later. ${ }^{2}$ Crowds still descended on churches to hear skilled episcopal orators like Jean-Pierre Camus and the celebrated Bossuet, but it was no longer an extraordinary spectacle. The newly popular notion of preaching as a worthy and vital occupation for bishops, and as a skill to be admired and valued, was quickly grasped by many prelates who understood that this was a means of fulfilling the demands of their office. Episcopal preaching came to be widely considered as both pre-eminent and customary.

While French churchmen agreed on the premier position of bishops within the hierarchy as well as on the character of the spirituality that was to motivate their pastorate, they managed, however, to concur about little else concerning the functions and status of the office. The greatest difficulties arose over questions of jurisdiction, particularly in relation to the interpretation and implementation of Trent's decrees. Certainly it was universally accepted that bishops possessed powers of both order and jurisdiction. It was these that distinguished them from priests, although episcopacy, it was held, was not a separate sacrament from the priesthood. But resolution of the long-disputed issue of episcopal sacramentality did not help the French when they turned to deal with the bishop's jurisdictional authority in detail. For the episcopate itself, the character of its jurisdiction was quite clear and was not conducive to compromise with its rivals. Bishops governed their dioceses according to divine right and law. As the century progressed, and their efforts to interpret and develop the reform decrees of Trent were opposed by regulars, bishops began to adopt explicitly this theory to defend their leadership and disciplinary 
authority. The episcopate's ideal prelate would resist, therefore, all efforts by the papacy to interfere in diocesan government without his consent, on the basis of his divinely granted power of jurisdiction.

For the bishops' regular opponents and the papacy, however, prelates should act as delegates of the pope, submitting to his superior and universal authority over the entire church. Even more significantly, the discrepancies between these two viewpoints rested not simply on different interpretations of Trent's decrees but, most fundamentally, on the competing conceptions of the ecclesiastical hierarchy and the church which actually determined each party's attitude towards the Council's programme: French bishops supported a monarchical style of government within dioceses, with episcopal jurisdiction over both regular clergy and curés, while advocating a more collegial framework within the church as a whole. This was wholly unacceptable to either French regulars or the papacy since it allowed bishops far too independent a rein in their dioceses. To the papacy's dismay, it also offered them the upper hand in general church government through ecumenical councils and severely restricted papal jurisdiction over the whole church as well as within individual dioceses. In this, it was related to the rising belief within the episcopate that bishops were empowered by God to act as spiritual judges, both individually and corporately.

The episcopate's view of its diocesan jurisdiction did not just create difficulties for its relationship with the regulars and the papacy. It also ran contrary to the hierarchical and governmental ideals proposed by French curés. While they applauded episcopal independence from the papacy, the curés were equally vociferous defenders of their own jurisdictional droit divin, though their claims were successfully quashed by an alert episcopate in 1657. In addition, an Assembly progressively dominated by the episcopate meant that in future the opinions of curés and regulars counted for less in its deliberations and decisions and, therefore, in the official policies of the French church. These tussles over jurisdiction with the papacy and regulars as well as with the curés produced a strong sense of collegiality within the episcopate, of unity in the face of adversity, and the conviction that all bishops must protect the rights and powers of their office for future generations.

Again, altercations with the state usually hinged on acrimonious jurisdictional issues, with the episcopate considering its role to be that of defender of the church against the aggressive and unwarranted jurisdictional incursions of the secular realm. Disputes of this sort, whether over the trial of bishops or over appels comme d'abus, served not only to develop cohesion and self-identity within episcopal ranks but also to encourage a sense of episcopal responsibility for the well-being of the entire church, rather than just the episcopate. This was the ideal advocated by bishops themselves and by those who published works on episcopacy but, in practice, it really occurred only in church-state 
disputes. Excluding the Jansenist bishops, the episcopate's clashes with the papacy and lower clergy tended to focus purely on defending the rights of bishops, rather than on the more pastoral issue of universal church welfare. Although the tendency of the Assembly prelates to act as spiritual judges was at least partly inspired by a desire to guide the faithful in questions of salvation, it was principally motivated by their wish to play a prominent role in ecclesiastical government and by the belief that the pope was not the sole judge and authoritative voice within the Catholic church.

It is apparent, therefore, that there were acute tensions between the vision of the ideal bishop formulated by the French episcopate and its close associates like Olier and de Paul and the ideals of the lower clergy, the papacy and the crown. French bishops and their apologists certainly clung fast to an episcopal ideal that neatly answered their qualms about the functions and status of prelates: it was built on the twin foundations of jurisdictional power and pastoral duty, though they were conceived in a way that ascribed substantial freedom of action to bishops. While a bishop had certain obligations according to which he defended his office and the church, acted as an enlightening and inspirational force towards his charges and strove to live a life of charitable sacrifice for God, he also, by virtue of the elevated status of his position, held certain immutable privileges which could never be questioned. While the episcopate's opponents accepted that, in principle, a bishop had duties and rights, they interpreted these in a different way from the episcopate. For regulars and Rome, prelates should act in a delegatory fashion, leaving supreme government to the pope. Curés and the crown, in contrast, agreed with bishops that their jurisdiction was not held from the pope. Yet they too conceived their own jurisdiction in a way which benefited them but left a sensitive episcopate feeling short-changed of its legitimate power.

Despite the fact that no ideology of episcopacy or even an image of the accomplished bishop to which all parties could enthusiastically adhere developed during the course of the century, it is evident that, supported by leading figures within reform circles, the bishops succeeded in imposing their view of episcopacy and consequently of the role and status of bishops on their ecclesiastical opponents and even, to some extent, on the French crown itself. This does not mean that they managed to convince their adversaries that their ideas were correct or even that resistance to their opinions evaporated entirely since, as we have seen, this was certainly not the case. However, the bishops proved to be tenacious defenders of their position and, significantly, it had become more difficult by the 1660s for rival views to be aired and to have any real influence. It was the episcopate's ideals which imprinted themselves upon the French church and which shaped its governing and hierarchical structure. 
The success of the episcopate in ensuring that its views dominated the French church is palpably obvious in the latter half of the seventeenth century. By this time, the bishops had succeeded in silencing the claims of curés for independent government in their parishes by facing down the Parisian curés and their provincial associates during the later 1650s. Although this stand-off was the climax of curial grievances voiced since the 1620s, the episcopate's show of force at this stage meant that the authority of bishops over their parish clergy was firmly defined for the future. Thereafter, curés would nurse festering grievances against what they considered to be an autocratic episcopate and an unjust system of ecclesiastical government that failed to allow them their due influence. Yet it is no coincidence that the 1650s were to offer the final occasion, before the Revolutionary years, on which they would attempt to defy their hierarchical superiors by acting as a corps. The outburst of opposition by curés against their bishops that characterised the late eighteenth century was a direct, and naturally unintended, result of an episcopal ideology that excluded curés from an effective voice in government, but it was a tribute to the intense potency of this ideology that it took so long for the parish clergy to regain the corporate unity of action displayed during the 1650s. ${ }^{3}$ So too the episcopate had, through the seventeenth century, successfully repulsed all efforts by both French regulars and the papacy to restrict its diocesan jurisdiction and had produced several declarations in the Assembly which endorsed its view of jurisdictional droit divin. These it regarded as binding on the French church. Regulars continued to oppose their bishops' authority within dioceses but with decreasing hope of having their claims upheld as legitimate. In practice, it was the bishops' ideal of episcopal control of hierarchical functions that was being progressively imposed upon the French church. Very importantly too, there were growing indications that the crown favoured the episcopate's view of the ecclesiastical hierarchy and government, despite occasionally upholding regulars' appels against bishops through the provincial parlements. Indeed, the 1669 arrêt d'Agen and the 1695 edict confirming episcopal jurisdiction over regular and curial sacramental activities and preaching cemented that tendency.

In also ensuring that the privileges associated with their ecclesiastical rank were protected, bishops managed to impress their views upon the French church. Any effort by the papacy to try bishops in a form that the episcopate deemed contrary to their elevated rank was successfully rebutted, so that it was the bishops' claims which were carried. Although, therefore, the papacy might in the future attempt to challenge these, it would be extremely difficult for it to succeed in doing so, faced with a united episcopate and a French church that had for decades withstood such on the basis of well-constructed and forceful arguments. In tandem, the episcopate had managed to refute Rome's efforts to use papal privileges as a means by which the papacy could increase its jurisdictional 
sway in dioceses, and had embraced a doctrine of conciliarism and of spiritual judgement that rode roughshod over any papal pretensions to dogmatic autocracy. By the time the episcopate signed the Articles of 1682, its relationship with the papacy had become so taut that the views enshrined in three of its Articles were simply the expression of a defiant episcopal ideology matured over the course of several decades. These conclusions incline one to caution in considering the rhetoric of absolutism that surrounded the papacy as the Tridentine era progressed. ${ }^{4}$ The seventeenth century is generally considered to have been one of the pivotal historical periods in which Rome steadily consolidated its power throughout the church, by centralising government and forcing obedience to its will. Yet care should be taken in judging the success of this process, for it is clear that, thanks to the independently-minded leaders of the French church, the papacy fought a losing battle to stamp its authority on one of the largest European territories of the Catholic church. Of course, the bishops were not alone in contributing to that outcome, for Richerist curés, the Jansenists and the crown certainly played their part in handicapping papal interventions in French ecclesiastical affairs. The episcopate led the way, however, for by successfully assuming such hawkish opposition to papal interventions in episcopal and ecclesiastical government it consistently made a robust and exemplary stand against the papacy's pretensions to supreme rule.

Even the increasingly powerful Bourbon state was, to some extent, progressively coloured by the ideology professed by its bishops. In the Retz episode, the bishops' strenuous criticism of Mazarin's plan to judge the disgraced cardinal in the secular courts ultimately resulted in the crown's abandonment of the planned procedure, for fear of arousing further episcopal opposition. Undoubtedly too, the episcopate's independent and moderately gallican stance towards the papacy could only have pleased the crown. On the complicated question of church-state jurisdictional boundaries, however, the French monarchy proved unwilling to accept the bishops' claim that the crown should avoid any unsolicited interference in ecclesiastical causes, which they alone, as the leaders of the church, should resolve. Although the crown paid lip service to the bishops' persistent calls for royal endorsement of this view, it palpably failed to translate it into practice and repeatedly supported its officials, in one way or another, when they intervened in spiritual matters. Even the Assembly, with its growing prestige as the mouthpiece of the episcopate and the French church, was unable to force the crown to adopt policies which would limit secular intervention in ecclesiastical causes. Of course, it did not help that the bishops themselves regularly blurred the boundaries that they had erected by appealing to the secular arm and by immersing themselves in temporal affairs. The consequences of that contradictory behaviour became only too evident as the crisis over the régale unfolded into the Gallican Articles and 
the bishops spectacularly failed to protect their church from the monarchy's voracious appetite for power. In the eighteenth century, that pattern would be perpetuated as the parlements redoubled their efforts to draw the church under their jurisdictional wings and as the crown, once again, became involved in a new outbreak of the Jansenist conflict. ${ }^{5}$ However, the decisive steps that ushered in those developments were made by an earlier generation: the episcopate's sustained failure, over the course of the previous century, to impose its view on the crown marked a critical progression in the increasing influence of the French state over the church, since it was only the bishops, as the most powerful group within the clergy, who could have any hope of halting secular intervention in ecclesiastical affairs.

The crown's reluctance to accept the bishops' view of ecclesiasticalsecular jurisdiction is illuminating when we consider why it actually did accept so many features of the ideology espoused by the episcopate and by its close supporters. It proved willing to embrace those ideas which suited and benefited it or, at least, which did not have any obvious detrimental effect on royal power. From Henri IV onwards, the crown proved progressively attuned to reformers' calls for worthy nominations to episcopal seats, using the basic criteria, from the 1516 Concordat, that appointees should be of mature age, in orders and men of virtue. Its attitude was not entirely utilitarian and opportunistic since Louis XIII, Anne of Austria and even Louis XIV were swayed by the religious arguments of prominent reformers. All the leading reformers were closely linked to the crown, corresponding with ministers and monarchs and even, in one or two cases, filling positions within the Conseil de Conscience. They were thus in an ideal position to influence royal opinion and policy and they grasped every opportunity for doing so. Like the episcopate itself, the crown could not fail to be affected by the climate of reform prevalent in France and mediated by its religious advisors. With the royal family and ministers like Richelieu personally close to charismatic and dedicated reformers, appointments regularly took on a personal importance for salvation and divine service, as well as being an important means of extending monarchical power. As Jean Eudes repeatedly reminded the queen regent, Anne of Austria, it was her duty to provide the church with worthy bishops, an obligation for which God would ultimately judge her. ${ }^{6}$ Richelieu made the same point in his Testament.

Obviously, it suited the crown to promote men who were educated virtuous, mature and experienced administrators, since it was well aware that bishops with these qualities could be depended on to promote religious and social order in their dioceses. Of course, new bishops did not always fulfil the reformers' criteria, and the episcopate would continue to have many men of whom those like de Paul disapproved. Appointments could still be subject to the petty whims of leading politicians and churchmen, a classic example being 
Archbishop Harlay's blockage of Fénelon's elevation to no fewer than two dioceses (Poitiers and La Rochelle). Although the archbishop justified his action on the basis that the young abbot was tinged with Jansenism, it was well known that the reality was far less pure: the snub was a bitter personal revenge for Fénelon's previous rejection of Harlay's friendship and his alignment with Bossuet, an enemy of the archbishop. ${ }^{8}$ In general, however, the result of the crown's efforts to measure its nominees against set ecclesiastical criteria was the emergence of a far more uniform episcopate by the mid-1600s. ${ }^{9}$

The improved standards in appointments and in the quality of episcopal tenure were marks of the impression that the reformers' ideals made upon the episcopate, the church and the crown. Yet even as its impact was felt, the entire climate of reform began to grow distinctly cooler. At its height, a host of reformers had worked ceaselessly, individually and within organisations, to provide bishops with inspirational ideas of episcopal leadership, virtue and pastoral care, and had persistently encouraged them to emulate the examples of those who fulfilled them. As its leaders, like Olier and Eudes, died out, their places were not taken by others with the same genius for inspiring and directing the episcopate. It is fair to wonder why later ecclesiastics like Bossuet or Fénelon, well positioned and always with pens to hand, failed to perpetuate the creative fervour of the reform movement, and to show the same concern with presenting and constructing episcopal visions for their fellow bishops to put into practice. On the one hand, there is no doubt that the radical dwindling of the entire reform movement in the later 1600s actually had a similar effect on the energy channelled towards episcopal rejuvenation. But, generally, one could not accuse either Bossuet or Fénelon of insouciance in his piety or in his eagerness to engage in spiritual debate through publication on a myriad of topics, so it is equally probable that they and others simply did not feel the need to expand on an episcopal ideal that already appeared to have been developed to its optimum condition. In turn, that pastoral and spiritual image fitted into a broad understanding of episcopacy that provided bishops with a profound sense of self-identity through which their position and role within church and society were both manifested and justified. It would continue to shape episcopal actions and attitudes until the coming of the Revolution, but its unquestioned, and rather complacent, adoption as a fully matured ideology meant that it lost the dynamic capacity for evolution that had been such a significant ingredient in its growth and success.

The path taken by the episcopate towards its ideology illuminates the complexities of implementing Tridentine reform, with its potentialities for rivalry and suspicion as well as inspirational theological and spiritual visions, and the difficulties of accommodating those ideals to secular society. It was immensely difficult for the episcopate to formulate an identity that would not injure other 
parties in the church, not to mention the state's representatives. Its attempts to do so occasionally met with praise, but more often than not they produced acrimonious debates which, as those involved knew perfectly well, would possibly determine the locations of power and privileges within the church and society. Ultimately, therefore, the episcopate's adoption of a comprehensive ideology of episcopacy had its effect not just on bishops themselves but also on the lower clergy, the papacy and the crown. For this reason, it is obvious that the seventeenth century was a formative period not just for the character of the episcopate itself but for that of the French church in general. Although that church had always been hierarchically structured it was now more rigidly stratified than ever, with a powerful episcopate, sure of its leadership and furnished with potent theological and canonical arguments to defend this. On these bases, this was, in fact, a church that could truly be termed episcopal, for its bishops' ideology shaped the path and outcome of virtually every major event punctuating its development. Significantly, the lower clergy were increasingly finding it practically impossible to challenge the episcopate's views of jurisdiction, so that within the ecclesiastical sphere, the bishops stood out as the dominant forces in government and the sources of enlightenment for all the faithful. To be truly and thoroughly episcopal, however, the church would have needed complete independence from the crown, and neither it nor its episcopal leadership secured that. After it had successfully resisted what it considered to be unwarranted papal attacks on its privileges and powers, the sole force of which the episcopate might be wary was apparently the Bourbon government, with its unbounded enthusiasm for intervening in ecclesiastical causes. Yet, in general, with a coherent ideology upon which to base their ministry, bishops could afford, as the seventeenth century drew to a close, to be confident in their position, assured of their ecclesiastical and social prestige and secure in the strength of their leadership.

Notes

1 Fumaroli, Eloquence, p. 140.

2 Hervé Martin, Le Métier du predicateur à la fin du Moyen Âge, 1350-1520 (Paris 1988), pp. 131-2; Taylor, Soldiers, pp. 37, 248.

3 Nigel Aston, Religion and Revolution in France, 1780-1804 (Basingstoke 2000), pp. 103-62; McManners, Ecclesiastical Society, pp. 173-277; Ruth Necheles, 'The Curés in the Estates General of 1789', Journal of Modern History, 46 (1974), 425-44.

4 Prodi, Prince.

5 For the history of jurisdictional disputes between the episcopate and the parlements under later Bourbons, see Ravitch, Sword, pp. 34-50. On eighteenth-century Jansenism, see Doyle, Jansenism, pp. 45-90.

6 Eudes, Oeuvres, xi, p. 53, letter to queen mother, 2 September 1648; ibid., p. 64, letter to same, 1653.

7 Richelieu, Testament, pp. 130-5.

8 Harlay reportedly told Fénelon that 'You desire to be forgotten, and you will be, M. l'Abbé!': Sanders, Fénelon, pp. 19-20.

9 Bergin, Episcopate, pp. 248-53. 


\section{Appendix: chronology of principal events}

1545-47 First session of the Council of Trent

1551-52 Second session of Trent

1561 Colloquy of Poissy

1562-63 Third session of Trent

1562 French delegation arrives at Trent (November)

1578 Fourth Council of Milan

1584 Charles Borromeo dies

1610 Charles Borromeo is canonised

1611 Pierre de Bérulle founds the Congregation of the Oratory

1615 French Assembly of Clergy formally accepts the decrees of the Council of Trent

1622 François de Sales dies

1624 Council of Bordeaux

Richard Smith is appointed bishop of Chalcedon (with responsibility for the English church)

$1625 \quad$ Louytre crisis

Déclaration sur les réguliers

Vincent de Paul founds the Lazarist Congregation

1629 Bérulle dies

Richard Smith crisis begins in France

1631 Bishops' letter condemning 1629 anti-episcopal treatises by Edward Knott and John Floyd

Archbishop of Paris' censure of treatises by Knott and Floyd

1632-33 Episcopal defences by the Abbé de Saint-Cyran, François Hallier and Nicolas Le Maistre

Five French bishops deposed by papal commission

1640 Augustinus published

1643 Jean Eudes founds the Congregation of Jesus and Mary (Eudists) In Eminenti 
1645 Jean-Jacques Olier founds the Sulpician Congregation Episcopal protests against the judgements of Bishops Rieux and Delbène (1645-51)

1649 Jansenist propositions are sent to Rome

1651 Olier offers the Projet de l'établissement d'un séminaire dans un diocèse to the episcopate

1652 Cardinal de Retz is arrested (December)

1653 Cum occasione

Curés' Fronde begins

1654 Retz is appointed to the archbishopric of Paris (March)

1655 Assembly produces the anti-Jansenist Formulary

1656 Ad sanctam B. Petri sedem

1657 Twelve articles on episcopal jurisdiction and droit divin

Olier dies

1660 De Paul dies

1661 Lettre de cachet to oblige signature of the anti-Jansenist Formulary

1662 Arrêt commanding bishops and archbishops to sign the Formulary

Retz resigns from the archbishopric of Paris

1663 Brief by Pope Alexander VII supporting condemnation of the five propositions

1664 Royal declaration demanding that bishops sign the Formulary within one month

1665 Regiminis apostolici

De Sales is canonised

1669 Arrêt d'Agen

Superna magni patrisfamilias praeordinatione

Paix de l'église

1673 First royal declaration on the régale

1675 Second royal declaration on the régale

1678 Innocent XI's first brief against the régale (March)

Innocent's XI's second brief against the régale (September)

1679 Innocent XI's third brief against the régale (January)

$1680 \quad$ Eudes dies

1682 Episcopate's confirmation of the extended régale (February)

Gallican Articles (March)

Innocent XI's brief demanding bishops retract their confirmation of the extended régale 
1693 Episcopal apology to Innocent XII

1695 Royal edict on ecclesiastical jurisdiction

1713 Unigenitus 


\section{Bibliography}

\section{Manuscript sources}

Archives des Affaires Etrangères, Paris

Mémoires et documents. France, 805.

Archives Nationales, Paris

G8* 643a, G8* 643b, G8* 648a, G8* 652, G8* 653, G8* 655b, G8* 657a, G8* 658a, G8*659a, G8*664A.

L 741.

X1a 8394.

Bibliothèque de l'Arsénal, Paris

6042 .

Bibliothèque Mazarine, Paris

4340 .

Bibliothèque Nationale, Paris

3637.

Baluze 122.

Dupuy 357.

Français (Fr.) 3677, 14428(i), 24075.

Français (Fr.) ii 635.

Mélanges de Colbert, 7.

Bibliothèque Sainte-Geneviève, Paris

2131.

3238.

3249 . 


\section{Primary printed sources}

Abelly, Louis, Episcopalis sollicitudinis enchiridion ex plurimorum ecclesiae catholicae antistitum sanctitate, ac pastorali vigilantia insignium, et praesertim D. Caroli Borromaei $S$. R. E. C., archiep. Mediolan. theoria et praxi accurate collectum, complectens summatius omnia (Paris 1668).

Abra de Raconis, Charles François de, La Primauté et souveraineté singuliere de Sainct Pierre (Paris 1645).

, Declaration de monsieur l'evesque de L'avaur, touchant une lettre supposée par luy escrite a

N. S. Pere le Pape: et presentée à messeigneurs de l'assemblée du clergé de France (Paris 1646).

Acte parfaict hiérarchique, auquel par un concours de la puissance papale avec l'archiépiscopale, les droicts des privilégiez sont conservez et bornez en présence d'un légat (Gaillon 1644).

Ante-Nicene Christian Library: Translations of the Writings of the Fathers Down to A. D. 325, ed. Alexander Roberts and James Donaldson, 24 vols (Edinburgh 1867-68).

Arnauld, Antoine, Lettres de Monsieur Antoine Arnauld docteur de Sorbonne, 9 vols (Nancy 1727).

— Les Oeuvres de Messire Antoine Arnauld, docteur de la maison et societé de Sorbonne, 43 vols (Paris 1775-83).

Arnauld, Henri, Reglement de monseigneur l'evesque d'Angers pour ses domestiques (n.p. 1651).

, Lettre de monseigneur l'évesque d'Angers. Au roy. Sur le sujet de la signature du Formulaire du clergé (n.p. 1661).

-, Résponse de monseigneur l'évesque d'Angers, à la lettre que monsieur de Lionne lui avoit écrite, après avoir présenté et leu au roy celle dudit sieur évesque à sa majesté. Du 6. juillet 1661 (n.p. 1661).

__, Troisième lettre de monseigneur l'évesque d'Angers au roy, touchant la signature de Formulaire, par laquelle il répond à la lettre de sa majesté, du 28 aoûst 1662 (n.p. 1662).

__ Response de monseigneur l'évesque d'Angers à la lettre de monseigneur le nonce, du 29. aoûst 1662 (n.p. n.d.).

Arrest celebre du Conseil d'Estat, par lequel il est declaré que ceux qui destruisent la hiérarchie, sapent les fondemens de la monarchie (Gaillon 1634).

Autre relation plus recente et plus ample du progrez dont il plaist à Dieu de benir les soings et travaux de mondit seigneur l'illustrissime et reverendissime evesque de Cahors (n.p. n.d).

Bagot, Jean, Défense du droit épiscopal et de la liberté des fidèles touchant les messes et les confessions d'obligation (Paris, 1655).

Barcos, Martin de, Correspondance de Martin de Barcos abbé de Saint-Cyran avec les abbesses de Port-Royal et les principaux personnages du groupe Janséniste, ed. Lucien Goldman (Paris 1956).

Barrault, Jean Jaubert de, Homelies de l'excellence, necessité et diversité des croix et afflictions: et des vertus qui les doivent accompagner (Paris 1636).

Bascapé, Carlo, De vita et rebus gestis Caroli, S. R. E. cardinalis, tituli S. Praxedis, archiepiscopi Mediolani (Ingolstadt 1592).

Bertaut, Jean, Sermons sur les principales festes de l'annee composez par tres-reverend pere en Dieu Messire Jean Bertaud evesque de Seez, conseiller du roy en son Conseil d'Estat et privé, et premier aumosnier de la reyne (Paris 1613). 
Bérulle, Pierre de, Oeuvres complètes de Bérulle, cardinal de l'église romaine (Paris 1644). -, Oeuvres complètes du cardinal de Bérulle, ed. Jacques-Paul Migne (Paris 1856).

, Correspondance du cardinal Pierre de Bérulle, ed. Jean Dagens, 3 vols (Paris and Louvain 1937-9).

Binet, Étienne, Response aux demandes d'un grand prélat touchant la hiérarchie de l'église, et la juste défense des privilégiés et des réguliers (Nancy 1625).

- L'Idée des bons prélats et la vie de Saint Savinian, primat et premier archévesque de Sens, et de ses saints compagnons (Paris 1629).

_ De la sainte hiérarchie de l'église, et de la vie de Sainct Aderald, archdiacre et chanoine de Troyes, restaurateur de la communauté des chanoines (Paris 1633).

Bonichon, François, Défense des ordonnances de monseigneur l'évesque d'Angers et de l'authorite épiscopale contre deux libelles (Angers 1656).

—_ Extrait des principales faussetz mises par l'autheur des Réflexions sur le livre de la Deffense des ordonnances de monseigneur l'évesque d'Angers (Angers 1657).

- L'Authorité épiscopale défendue contre les entreprises de quelques réguliers mendiants du diocèse d'Angers sur la hiérarchie ecclésiastique (Angers 1658).

Bosquet, François, La Vie de S. Fulcran evesque de Lodeve (Paris 1651).

Bossuet, Jacques-Benigne, Oeuvres complètes de Bossuet, ed. F. Lachat, 31 vols (Paris 1865-66).

—, Oeuvres oratoires de Bossuet, ed. J. Lebarq, 7 vols (Paris 1890-7).

—, Correspondance de Bossuet, ed. C. Urbain and E. Levesque, 14 vols (Paris 1909-23).

Bourgoing, François, Exercices d'une retraite spirituelle de dix jours (Paris 1648).

Bourlon, Mathieu, Remonstrance faites à l'assemblée générale du clergé de France. Sur diverses enterprises contre l'authorité épiscopale, et les libertez de l'église (Paris 1660).

Bragelone, Emery de, Ordonnances synodales pour le diocese de Lucon (Fontenay 1629).

Cahier des remonstrances du clergé de France, presenté au roy par l'assemblée generale, tenue à Paris és années 1635 et 1636. Avec les responses faites par sa majeste sur lesdites remonstrances (n.p. n.d.).

Camus, Jean-Pierre, Homelies panegyriques de Sainct Charles Borromee, cardinal du titre de Sainct Praxede, archevesque de Milan (Paris 1623).

, De l'unite de hierarchie (Douai 1634).

- Considérations hiérarchiques (Paris 1642).

- Les Devoirs paroissiaux (Paris 1642).

- Les Fonctions du hiérarque parfait, où se voir le tableau de l'évesque accomply (Paris 1642).

, Les Emplois de l'ecclesiastique du clergé (Paris 1643).

_- L'Esprit du bien-heureux François de Sales, évesque de Genève, 3 vols (Paris 1840).

—_ Homélies des États Généraux (1614-1615), ed. Jean Descrains (Geneva 1970).

Camus de Pontcarré, Jacques, Remonstrance du clergé de France faitte au roy (Paris 1626).

Canons and Decrees of the Council of Trent, ed. H. J. Schroeder (Saint Louis and London 1941).

Cavet, Étienne, Pourtraicts racourcis de Sainct Charles Borromée, Saincte Thérèse, Soeur Marie de l'Incarnation, et du B. H. François de Sales, évesque de Genève (Lyon 1632). 
Cellot, Louis, De hierarchia et hierarchis (Rouen 1641).

The Censure of the Most Illustrious and Most Reverend Father in Christ, the Lord Archbishop of Paris (Paris 1631, reprinted Ilkley 1975).

Censures of Certaine Propositions, Partly Drawne out of Ireland, Partly Drawne out of Two English Bookes, where of the First is Intitled A Modest Discussion \&c. the Later An Apologie \&c. Given by the Most Illustrious, and the Most Reverend Arch-Bishop of Paris, as also by the Sacred Facultie of Sorbon (Douai 1631, reprinted Ilkley 1975).

Chastenet, Leonard, La Vie de Monseigneur Alain de Solminihac évesque baron, et comte de Caors, et abbé régulier de Chancellade (Cahors 1665).

Chrestian, André, Replique pour les curéz du diocèse de Rouen. À la response de Maistre Adrian Behotte chanoine et archidiacre en l'église de Rouen. Touchant le prétendu droict de visite des archidiacres (Rouen 1628).

Cinq visites ad limina, ed. J. Contrasty (Paris 1913).

Collection des procès-verbaux des assemblées générales du clergé de France, ed. A. Duranthon, 9 vols (Paris 1767-78).

Le Concile provincial des diocèses de Normandie tenu à Rouen l'an MDLXXXI, par monseigneur l'illustrissime et révérendissime cardinal de Bourbon archévêsque du dict lieu, corrigé et confirmé par nostre sainct père le pape Gregoire XIII (Paris 1582).

Concilia novissima Galliae, ed. Ludovicus Odespun de La Méchinière (Paris 1646).

Condren, Charles de, L'Idée du sacerdoce et du sacrifice de Jesus-Christ donnée par le R. P. de Condren second superior general de l'Oratoire de Jesus avec quelques eclaircissements et une explication des prieres de la messe par un prêtre de l'Oratoire (Paris 1677).

, Oeuvres complètes du P. Charles de Condren, ed. Louis-Marie Pin, 2 vols (Paris 1857-58).

— Lettres du père Charles de Condren (1588-1641), ed. Paul Auvray and André Jouffrey (Paris 1943).

Cospeau, Philippe, Remonstrance du clergé de France, faicte au roy le 18. iuillet (Paris 1617).

David, Michel François, Lettre envoyée à monseigneur le reverendissime archévesque de Rouen, primate de Normandie, \&c. (Rouen 1620).

Decrees of the Ecumenical Councils, ed. Norman P. Tanner, 2 vols (London and Georgetown 1990).

Les Diocèses d'Alet et de Pamiers d'après une relation contemporaine, ed. Marc Dubruel (Foix 1913).

'Documents divers relatifs au concile provincial de Bordeaux', ed. Ducaunnes-Duval, Archives Historiques du Département de la Gironde, 17 (1877), 377-500.

'Documents inédits', ed. Philippe Tamizey de Larroque, Revue de Gascogne, 8 (1867), 91-6.

'Documents inédits', ed. Philippe Tamizey de Larroque, Revue de Gascogne, 20 (1879), $402-7$.

'Documents inédits. Lettres de Henry de Sponde, évêque de Pamiers', ed. Philippe Tamizey de Larroque, Revue de Gascogne, 15 (1874), 547-52.

'Documents inédits. Lettres de Henry de Sponde, évêque de Pamiers', ed. Philippe Tamizey de Larroque, Revue de Gascogne, 24 (1883), 352-63.

Documents relatifs aux rapports du clergé avec la royauté de 1682 à 1705, ed. Léon Mention (Paris 1893). 
Documents sur M. de Caulet évêque de Pamiers et sur le schisme de la régale dans ce diocèse, ed. Jean-Marie Vidal (Castillon-en-Couserans 1936).

Double patentes de l'ancienne église gallicane, tirées des archives du palais archiepiscopal et du chapitre de l'église métropolitaine et primitialle de Rouen (Gaillon 1643).

Du Perron, Jacques davy Les Diverses Oeuvres de l'illustrissime cardinal Du Perron, archevesque de Sens, primat des Gaules et de Germanie, et grand aumosnier de France (Paris 1622).

Dupuy, Pierre, Traitéz des droits et libertéz de l'église gallicane (n.p. 1639).

— Preuves des libertéz de l'église gallicane (n.p. 1639).

Duvergier de Hauranne, Jean, Assertio epistolae, episcoporum in querimoniam (Paris 1632).

, Vindiciae censurae facultatis theologiae Parisiensis in Spongiam (Paris 1632). ses amis. Touchant les dispositions à la prestrise (n.p. 1647).

- Lettres chrestiennes et spirituelles de messire Jean Du Verger de Hauranne abbé de S. Cyran, 2 vols (Paris 1647).

An Epistle of the Arch-Bishops Now Assembled at Paris to the Arch-Bishops and Bishops of the Kingdome of France, Concerning the Censure of Two Pamphlets (Paris 1631, reprinted Ilkley 1975).

Estella, Diego de, Modo de predicar y modus concionandi: Estudio doctrinal y edicion critica (Salamanca 1576).

Etampes, Leonor d', Advis de l'assemblée générale du clergé de France. À messieurs les archévesques et évesques de ce royaume (Paris 1625).

- Declaration de messieurs les cardinaux, archevesques, evesques, et autres ecclesiastiques deputez en l'assemblée generale du clerge de France, tenue à Paris. Touchant certains libelles faicts contre le roy et son estat (Paris 1626).

Eudes, Jean, Advertissements aux confesseurs missionnaires (Caen 1644).

$\longrightarrow$, Le Bon Confesseur (Paris 1666).

- Manuel pour une communauté d'ecclésiastiques (Caen 1668).

— Le Mémorial de la vie ecclésiastique (Lisieux 1681).

- Le Prédicateur apostolique (Caen 1685).

- Oeuvres complètes du bienheureux Jean Eudes, 11 vols (Paris and Vannes 1905-9).

L'Extension de la régale à tous les évêchés de France, ed. Marc Dubruel (Toulouse 1911).

Extrait de quelques maximes de l'anonyme, intitulé L'Obligation des fidèles, et $c$. et de quelquesuns de ses sentiments; principalement contre l'authorité du pape et des évesques (n.p. n.d.).

Faure, François, Remonstrance du clergé de France faite au Roy (Paris 1666).

Fénelon, François de Salignac de La Mothe-, Correspondance de Fénelon, ed. Jean Orcibal, Jacques Le Brun and Irénée Noye, 17 vols (Geneva 1972-99).

- Fénelon. Oeuvres, ed. Jacques Le Brun, 2 vols (Paris 1983-97).

Fleury, André-Hercule de, Oeuvres de l'Abbé Fleury (Paris 1884).

Floyd, John, An Apology of the Holy See Apostolicks Proceeding for the Government of the Catholicks of England during the Tyme of Persecution. With a Defense of a Religious State (Rouen 1630).

Frémiot, André, Ordonnances ecclésiastiques et statutz synaudaux faictz par monseigneur 
l'archévesque de Bourges patriarche primat d'Aquitaine, pour le réglement et police du clergé de son diocèse (Bourges 1608).

Gavanto, Bartholomaeo, Enchiridion seu manuale episcoporum (Paris 1635).

Gerbais, Jean, Ordinationes universi cleri gallicani circa regulares conditae, primum in comitiis generalibus anni 1625 (Paris 1665).

Giussano, Jean-Pierre, Histoire de la vie, vertus, mort et miracles de Saint Charles Borromée, cardinal prêstre du titre de Saint Praxede, archévesque de Milan, trans. Nicolas de Soulfour (Paris 1615).

Godeau, Antoine, Remonstrance du clergé de France, faite au roy, la reyne regente s amere presente, le 7. aoust 1651. par reverend pere en Dieu Messire Antoine Godeau evesque de Grasse et Vence; assisté de monseigneur le prince de Conty, et de messeigneurs les archevesques et evesques qui se sont trouvez à Paris (n.p. 1651).

, La Vie de S. Augustin évesque d'Hyponne (Paris 1652).

- Discours sur les ordres sacréz, où toutes les cérémonies de l'ordination selon le pontifical romain sont expliquées (Paris 1653).

, Histoire de l'église, 6 vols (Paris 1653).

- La Vie de Saint Charles Borromée, cardinal du titre de Sainte Praxede, et archévesque de Milan (Paris 1657).

—, Traité des séminaires (Aix 1660).

- Éloge historique du bienheureux François de Sales, évesque et prince de Genève (Paris 1663).

__ Éloge des évesques, qui dans tous les siècles de l'église ont fleury en doctrine et en sainteté (Paris 1665).

- Lettre éscrite au roy par monseigneur l'évesque de Vence, touchant la signature du Formulaire, 15 octobre 1661 (n.p. n.d.).

__ Résponse de monseigneur l'évesque de Vence à la lettre du roy, pour la signature du Formulaire pur et simple, août 1662 (n.p. n.d.).

- Lettres de M. Godeau, évesque de Vence, sur divers sujets (Paris 1713).

Grenade, Louis de, De officio et moribus episcoporum aliorumque praelatorum (Lisbon 1565).

, Ecclesiasticae rhetoricae, sive De ratione concionandi (Lisbon 1576).

Guyon, Symphorien, Histoire de l'église et diocèse, ville, et université d'Orléans, 2 vols (Orleans 1647-50).

Habert, Isaac, De l'union de l'église avec l'éstat (Paris 1641).

Hallier, François, Defensio ecclesiasticae hierarchiae, seu vindiciae censurae facultatis theologiae Parisiensis, adversus Hermanni Loemelii Spongiam (Paris 1632).

, De la iurisdiction ecclésiastique au royaume de France (n.p. 1651).

Henri IV, François de Sourdis et l'affaire des autels. Trois lettres inédites du roi Henri IV, ed. E. Allain and P. Tamizey de Larroque (Bordeaux 1893).

Hermant, Godfroy, Mémoires de Godefroy Hermant, sur l'histoire ecclésiastique du xviie siècle (1630-1663), 6 vols (Paris 1905-10).

Hervet, Gentian, Le Sainct, Sacré et Général Concile de Trente (Reims 1564).

Instructions et lettres des rois tres-chrestiens et de leurs ambassadeurs et autres actes concernant le Concile de Trente pris sur les originaux (Paris 1654).

Kellison, Matthew, A Treatise of the Hierarchie and Divers Orders of the Church against the 
Anarchie of Calvin (Douai 1629).

Knott, Edward, A Modest Briefe Discussion of some Points Taught by M. Doctour Kellison in his Treatise of the Ecclesiasticall Hierarchy (n.p. 1630).

La Béraudière, François de, Otium episcopale (Perigieux 1635).

La Chambre, Claude de, Panégyrique de S. Charles Borromée cardinal et archévesque de Milan prononcé en l'église de Saint Jacques de la Boucherie (Paris 1670).

La Moriniere, M. de, Les Vertus du vray prelat, representées en la vie de monseigneur l'eminentissime cardinal de la Rochefoucault, divisée en quatre livres (Paris 1646).

La Mure, Jean-Marie de, Histoire ecclésiastique du diocèse de Lyon (Lyon 1671).

La Rochefoucauld, François de, De l'estat ecclésiastique (Lyon 1597).

, Raisons pour le désaveu fait par les évesques de ce roiaume d'un livret publié avec ce tiltre Jugement des cardinaux archévesques et autres qui se sont trouvés en l'assemblée générale du clergé de ce roiaume sur quelques libelles diffamatoires (Paris 1626).

Le Camus, Etienne, Lettres du Cardinal Le Camus, ed. P. Ingold (Paris 1892).

Le Maistre, Nicolas, Instauratio antiqui episcoporum principatus, et religiosae erga eosdem monarchorum et clericorum omnium observantiae. Cui praemissa est confutatio rationum quas Sorbonicae censurae obiecit Spongia (Paris 1633).

Le Maistre de Sacy, Isaac, La Vie de Dom Barthélemy des Martyrs religieux de l'ordre de S. Dominique, archévesque de Brague en Portugal (Paris 1663).

Lemarie, Jean, Abregé de la vie, miracles, et canonisation de S. Charles Borromée, cardinal du tiltre de Sancte Praxede, et archévesque de Milan (Saint-Malo 1618).

Le Mee, Réné, Le prélat accomply, répresenté en la personne d'illustrissime seigneur Philippe Cospéan, évesque et comte de Lisieux (Saumur 1647).

Le Noir, Jean, L'Evesque de cour opposé a l'evesque apostolique. Premièr entretien sur l'ordonnance de monsieur l'evesque d'Amiens. Contre la Traduction du Nouveau Testament en françois, imprimé à Mons (Cologne 1674).

— L'Evesque de cour opposé a l'evesque apostolique. Second entretien (n.p. 1674).

_- L'Evesque de cour, opposé a l'evesque apostolique. Troisième entretien (Cologne 1675). , L'Evesque de cour, opposé a l'evesque apostolique. Quatrième entretien (Cologne 1675).

, L'Evesque de cour, opposé a l'evesque apostolique. Cinquième entretien (Cologne 1675).

Lescalopier, Nicolas, Le Protecteur de la maison de Dieu. Contre l'impieté, et l'ambition (Paris 1636).

Letter to the Dean and Canons of the Metropolitan Church of Sant André (n.p. 1642).

Lettre de l'assemblée générale du clergé de France (n.p. 1656).

Lettre de l'assemblée generale du clergé de France: au pape Urbain VIII sur la desirée beatification de feu Mr. de Sales, evesque de Genéve, trans. Pelletier (n.p. 1625).

Lettre de messieurs les archévesques, touchant la convocation des conciles provinciaux: par l'advis de l'assemblée générale du clergé de France, tenuë à Paris (Paris 1625).

Lettre de plusieurs prélats de France à N. S. P. le pape Clement IX sur la cause des quatre évesques, 1 décembre 1667 (n.p. n.d.).

Lettre des évêques commissaires généraux du clergé (n.p. 1633).

Lettre des religieux a monseigneur l'eminentissime cardinal duc de Richelieu (Paris 1632).

Lettre escrite a monseigneur l'évesque de Chaalons par monseigneur l'évesque d'Alet, touchant la 
signature du Formulaire, 1661 (n.p. n.d.).

Lorraine, Charles de, Lettres du cardinal Charles de Lorraine (1525-1574), ed. Daniel Cuisiat (Geneva 1998).

Marca, Pierre de, De concordia sacerdotij et imperij seu de libertatibus ecclesiae gallicanae (Paris 1641).

Marchetty, F., La Vie de Messire Jean Baptiste Gault, évêque de Marseille (Paris 1650).

Martyrs, Barthélemy des, Stimulus pastorum, ex sententiis patrum concinnatus in quo agitur de vita et moribus episcoporum aliorumque praelatorum (Rome 1564).

, Stimulus pastorum, ex sententiis patrum concinnatus in quo agitur de vita et moribus episcoporum aliorumque praelatorum (Paris 1644).

- Stimulus pastorum (Braga 1963).

Maubourg, Claude, Éloge historique, ou la vie de Saint Thomas de Villeneuve, religieux de l'ordre de Saint Augustin, archévesque de Valence, surnommé l'aumônier (Paris 1666).

Maupas Du Tour, Henri Cauchon de, Factum dressé par monseigneur l'evesque du Puy, pour justifier le droit qu'ont messeigneurs les evesques d'entrer dans les monasteres exempts, pour visiter la closture (n.p. 1653).

—. La Vie du vénérable serviteur de Dieu François de Sales (Paris 1657).

Mazure, Nicolas, L'Obligation des fidèles de se confesser à leur curé, pour respondre aux réflexions des réguliers sur le chapitre 21 du concile générale de Latran IV, tenu en l'année 1215, sous le pape Innocent III (Paris 1653).

Mémoires et journal sur la vie et les ouvrages de Bossuet, ed. François Guettée, 4 vols (Paris 1856).

Molinier, Étienne, La Vie de Mre. Barthélemy de Donadieu de Griet évesque de Comenge (Paris 1639).

Montchal, Charles de, Remonstrance faite à la reyne de la part de l'assemblée générale du clergé de France, par Messire Charles de Montchal archévesque de Toulouse, touchant l'affaire de Messire René de Rieux évesque de Léon (n.p. 1645).

Morel, Claude, La Conduite de Saint Augustin contre les Pelagiens, suivie par les evesques de France contre les Jansenistes (Paris 1658).

Morestel, Pierre, Le Guidon des prélats et bouclier des pasteurs (Paris 1634).

Nicole, Pierre, L'Idée d'un évêque qui cherche la verité (n.p. 1666).

Noulleau, Jean-Baptiste, Le Modele d'un grand évesque: d'un parfait prédicateur: d'un directeur des âmes accomply: d'un vray politique chrétien. En la personne de feu Messire Estienne de Villazel, très-digne évesque de S. Brieu (Paris 1665).

Nouveaux manuscrits de Cohon, évêque de Nîmes, ed. M. Bligny-Bondurand (Paris 1910). Olier, Jean-Jacques, Lettres spirituelles de M. Olier, ed. Louis Tronson (Paris 1672).

- Oeuvres complètes de M. Olier, ed. Jacques-Paul Migne (Paris 1856).

— Lettres de M. Olier, 2 vols (Paris 1885).

—, Quatre lettres inédites de M. Olier, ed. Louis Blazy (Foix 1931).

— 1984).

Ordonnances, advertissemens, et instructions aux recteurs, et autres ecclesiastiques du diocese de Pamiers (Toulouse 1630).

Ordonnances ecclesiastiques et statutz synaudaux faictz par monseigneur l'archevesque de 
Bourges patriarche primat d'Aquitaine, pour le reglement et police du clergé de son diocese (Bourges 1608).

Ordonnances et constitutions synodales, decrets, et reglements, donnez au diocese de Bourdeaus, puis l'an MDC jusques à present, en diverses années et occurrences (Bordeaux 1621).

Ordonnances et constitutions synodales, decrets et réglements donnez au diocèse de Bourdeaux par feu de bonne mémoire monseigneur le cardinal de Sourdis. Reveus, confirmés et augmentés par très-illustre et très-révérend père en Dieu Messire Henri Descoubleau de Sourdis, archévesque de Bourdeaux, et primat d'Aquitaine (Bordeaux 1639).

Le Pacifique à messieurs les évesques et curez. Pour les religieux (Paris 1625).

Paul, Vincent de, Saint Vincent de Paul. Correspondance, entretiens, documents, ed. Pierre Coste, 14 vols (Paris 1920-25).

Pirot, Georges, L'Apologie pour les casuistes contre les calomnies des Jansénistes (Paris 1657). Possevin, Jean Baptiste, Discours de la vie de Sainct Charles Borromée cardinal du tiltre de Saincte Praxède, et archévesque de Milan, trans. A. C. (Bordeaux 1611).

Premier extraordinaire de l'evesque de court. Touchant la domination episcopale exercée dans le diocese d'Amiens (Cologne 1675).

Pseudo-Dionysius, Pseudo-Dionysius. The Complete Works, trans. Colm Luibheid (New York 1987).

Rapin, René, Mémoires du P. René Rapin sur l'église et la société, ed. Léon Aubineau, 3 vols (Paris 1865).

Rébé, Claude de, et al., Monsieur, sur les difficultez que quelques religieux ont faictes depuis peu de temps en divers diocèses de subir nostre examen pour prendre la licence et approbation de prescher et confesser (n.p. n.d.).

Recueil des actes, titres et mémoires concernant les affaires du clergé de France, augmenté d'un grand nombre de pièces et d'observations sur la discipline présente de l'église, divisé en douze tomes et mis en nouvel ordre suivant la délibération de l'assemblée générale du clergé du 29 août 1705, 12 vols (Paris 1768-71).

Recueil général des anciennes lois françaises depuis lan 420 jusqu'à la Révolution de 1789, ed. François-André Isambert, 29 vols (Paris 1821-33).

Relation de ce qui se faict dans le diocese de Cahors, par monseigneur l'illustrissime et reverendissime evesque dudit lieu, pour remettre la discipline ecclesiastique dedans son clergé, et les devoirs de la vie chrestienne dedans son peuple (Paris 1640).

Remarques sur quelques decrets du concile provincial de Bourdeaux, tenu pas monseigneur l'illustrissime cardinal de Sourdis, au mois d'octobre 1624. Touchant les messes parochiales, les confessions à son propre curé à la feste de Pasques: et les exemptions des religieux (Paris 1625).

Remonstrances faites a l'assemblée generale du clergé de France sur diverses entreprises contre l'authorité episcopale, et les libertez de l'eglise (Paris 1660).

Retz, Jean-François-Paul Gondi de, Oeuvres de Retz, ed. J. Gourdault, R. de Chantelauze and C. Cochin, 11 vols (Paris 1870-1920).

Richelieu, Armand-Jean du Plessis de, Testament politique de Richelieu, ed. Françoise Hildesheimer (Paris 1995).

Richer, Edmund, Libellus de ecclesiastica et politica potestate (Paris 1611).

Rousse, Jean, Sommaire de la harangue de messieurs les curez de Paris, en l'assemblée générale du clergé, sur leur advis envoyé à messieurs les curez des autres diocèses, contre la fausse et pernicieuse morale du temps (Paris 1656). 
Sommaire des déclarations des curez de Paris: sur le vray sens des onze propositions, extraictes et obiectées contre le livre intitulé, 'De l'obligation des fidèles de se confesser à leur curé.' Contenant au fond la definition, les qualités, et fonctions du propre prestre (n.p. 1657).

, Extraict des propositions à examiner du livre intitulé 'Deffense du droict épiscopal'; et de la liberté des fidèles, touchant les messes, et les confessions d'obligation (n.p. n.d.).

Rouvier, Pierre, De Vita et rebus gestis Francisci de La Rochefoucauld (Paris 1645).

Rouvroy, Louis de, duc de Saint-Simon, Écrits inedits de Saint-Simon, ed. M. P. Faugère, 8 vols (Paris 1880-93).

Saint Martin, Simplician, Abrégè de la vie de Sainct Thomas de Villeneuve, l'aumosnier, archevesque de Valence, religieux de l'ordre des Hermites de Sainct Augustin (Châlons 1659).

_ La Vie de S. Thomas de Villeneuve, dit l'aumosnier, de l'ordre des Hermites de S. Augustin, archévesque de Valence (Toulouse 1659).

Sales, Charles-Auguste de, Histoire du bienheureux François de Sales (Lyon 1634).

Sales, François de, Introduction à la vie dévote (Arras 1610).

— Traicté de l'amour de Dieu (Lyon 1616).

- Les Oeuvres de Messire François de Sales evêque et prince de Genève (Toulouse 1637).

- Les Oeuvres du bienheureux François de Sales évesque et prince de Genève, 2 vols (Paris 1641).

, Oeuvres complètes de Saint François de Sales, 27 vols (Annecy 1892-1964).

- Introduction to the Devout Life, trans. John Ryan (New York 1989).

Selected Sermons of the French Baroque (1600-1650), ed. Peter Bayley (New York 1983).

A Select Library of Nicene and Post-Nicene Fathers of the Christian Church, trans. Charles Lett Feltoe, 12 vols (Oxford and New York 1895).

Silingardi, Gasparo, Correspondance du nonce en France. Gasparo Silingardi évêque de Modène (1599-1601), ed. Bertrand Haan (Rome 2002).

Solminihac, Alain de, Alain de Solminihac. Lettres et documents, ed. Eugène Sol (Cahors 1930).

Sourdis, Henri de, Sentence de mgr l'illustrissime archevesque de Bourdeaux contre les pères feuillans, jacobins, minimes et capucins, 22 novembre 1633 (n.p. 1633).

Sponde, Henri de, Annales sacri Henrici Spondani Appamiarum Galliae Narbonensis episcopi a mundi creatione ad eiusdem reparationem (Paris 1637).

, Lettres de l'évêque Henri de Sponde, ed. Jean-Marie Vidal (Foix 1930).

Statuts renouvellez par R. Père François de La Rochefoucault évesque de Clairmont: et publiez au S. synode tenu audict Clairmont le vingtuniéme jour d'octobre 1599 (Clermont 1599).

Testament de feu monseigneur l'evesque de Ballay, touchant sa sepulture (Paris 1652).

Troisième lettre de monseigneur l'évesque d'Angers au roy, touchant la signature de Formulaire, par laquelle il répond à la lettre de sa majesté, du 28 aoûst 1662 (n.p. 1662).

Tronson, Louis, Oeuvres complètes de M. Tronson, ed. Jacques-Paul Migne, 2 vols (Paris 1857).

, Correspondance de M. Louis Tronson, troisième supérieur général de la Compagnie de Saint-Sulpice, 3 vols (Paris 1900).

Valier, Agostino, De rhetorica ecclesiastica (Paris 1575). 
, Discours en manière d'instruction de ce qui appartient à la dignité épiscopale, trans. Chrétien d'Ebrard de Saint Sulpice (Paris 1585).

- Vita Caroli Borromei card. S. Praxedis (Verona 1586).

Varet, Alexandre-Louis, Relation de ce qui s'est passé dans l'affaire de la Paix de l'église sous le pape Clément IX, 3 vols (n.p. 1706).

Vernant, Jacques de, La Defence de l'autorité de N.S.P. le pape, de nosseigneurs les cardinaux, les archévesques et évesques, et de l'employ des religieux mendians. Contre les erreurs de ce temps (Metz 1658).

Villars, Pierre de, Opuscules et divers traictez, sur plusieurs sujects et matières ecclésiastiques. Même des principaux, et plus nécessaires articles de réformation, ordonnez par le sainct Concile de Trente, 2 vols (Lyons 1598).

\section{Reference works}

Dainville, François de, Cartes anciennes de l'église de France (Paris 1956).

Dictionnaire de biographie française, ed. Roman d'Amat et al. (Paris 1934-).

Dictionnaire de droit canonique, ed. R. Naz, 7 vols (Paris 1936-65).

Dictionnaire de spiritualité, 17 vols (Paris 1937-95).

Dictionnaire d'histoire et de géographie ecclésiastiques, ed. A. de Meyer et al. (Paris 1912-). Gallia Christiana novissima, ed. Joseph Albanès, 7 vols (Valence 1899-1920).

Marion, Marcel, Dictionnaire des institutions de la France aux xviie et xviii ${ }^{e}$ siècles (Paris 1923).

New Catholic Encyclopedia, 18 vols (New York 1967-2001).

\section{Secondary sources}

Abercrombie, Nigel, The Origins of Jansenism (Oxford 1936).

Alberigo, Giuseppe, Lo sviluppo della dottrina sui poteri nella chiesa universale (Rome and Freiburg 1964).

— , 'L'episcopato nel cattolicesmo riformato xvi-xvii secoli', in Bernard Vogler (ed.), Miscellanea historiae pontificae, viii (Brussels and Louvain 1987), 268-86. , 'Carlo Borromeo between Two Models of Bishop', in John M. Headley and John B. Tomaro (eds), San Carlo Borromeo. Catholic Reform and Ecclesiastical Politics in the Second Half of the Sixteenth Century (Wahington 1988), pp. 250-63.

Allison, Anthony, 'Richard Smith, Richelieu and the French Marriage. The Political Context of Smith's Appointment as Bishop of England in 1624', Recusant History, 7 (1964), 148-211.

_ , 'Richard Smith's Gallican Backers and Jesuit Opponents', Recusant History, 18 (1987), 329-401; 19 (1989), 234-85; 20 (1990), 164-206.

Almeida Rolo, Raul de, L'Evêque de la réforme tridentine. Sa mission pastorale d'après le vénérable Barthélemy des Martyrs, trans. Ceslas Salmon (Lisbon 1965).

Ardura, Bernard, Nicolas Psaume 1518-1575 évêque et comte de Verdun (Paris 1990).

Armogathe, Jean-Robert, Le Quiétisme (Paris 1973). 
Aston, Nigel, Religion and Revolution in France, 1780-1804 (Basingstoke 2000).

Baumgartner, Frederic, Change and Continuity in the French Church. The Bishops and the Wars of Religion 1547-1610 (Durham, North Carolina 1986).

, 'Renaud de Beaune, Politique Prelate', Sixteenth-Century Journal, 9 (1978), 99-114.

_ ' 'Crisis in the French Episcopacy. The Bishops and the Succession of Henry IV', Archiv für Reformationsgeschichte, 70 (1979), 278-97.

Bayley, Peter, French Pulpit Oratory, 1598-1650 (Cambridge 1980).

— , 'Les Sermons de Jean-Pierre Camus et l'esthétique Borroméenne', in Marc Fumaroli (ed.), Critique et création littéraires en France au xviie siècle (Paris 1977), pp. $93-8$.

Bégouen, Henri, Les Couserans aux xviie et xviii siècles (Foix 1901).

Beik, William, Absolutism and Society in Seventeenth-Century France. State Power and Provincial Aristocracy in Languedoc (Cambridge 1985).

Bell, Rudolph, and Donald Weinstein, Saints and Society. Christendom, 1000-1700 (Chicago and London 1982).

Benedict, Philip, Rouen during the Wars of Religion (Cambridge 1981).

Bergin, Joseph, Cardinal de La Rochefoucauld. Leadership and Reform in the French Church (New Haven and London 1987).

, The Making of the French Episcopate 1589-1661 (New Haven and London 1996). -, 'The Crown, the Papacy and the Reform of the Old Orders in Early SeventeenthCentury France', JEH, 33 (1982), 234-55.

, 'The Counter-Reformation Church and its Bishops', Past and Present, 165 (1999), 30-73.

Bernos, Marcel, 'Saint Charles Borromée et ses "Instructions aux confesseurs". Une lecture rigoriste par le clergé français ( $\mathrm{xvi}^{\mathrm{e}}-\mathrm{xix}^{\mathrm{e}}$ siècle)', Pratiques de la confession (Paris 1983), 185-200.

Black, C. F., 'Perugia and Papal Absolutism in the Sixteenth Century', English Historical Review, 96 (1980), 509-39.

Blet, Pierre, Le Clergé de France et la monarchie, 2 vols (Rome 1959).

— Les Assemblées de clergé et Louis XIV de 1670 à 1693 (Rome 1972).

- Histoire de la représentation diplomatique du Saint-Siège (Vatican City 1982).

— Le Clergé de France, Louis XIV et le saint siège de 1695 à 1715 (Rome 1989). - Les Clergé du grand siècle en ses assemblées 1615-1715 (Paris 1995).

-, 'L'Article du tiers aux états généraux de 1614', Revue d'Histoire Moderne et Contemporaine, 2 (1955), 81-106.

, 'Le Nonce en France au xviie siècle. Ambassadeur et délégué apostolique', Revue d'Histoire Diplomatique, 88 (1974), 223-58.

-, 'Vincent de Paul et l'épiscopat français', Vincent de Paul. Actes du Colloque International d'Etudes Vincentiennes (Rome 1983), 81-114.

, 'L'Idée de l'épiscopat chez les évêques français du xvii siècle', in Bernard Vogler (ed.), L'Institution des pouvoirs dans les églises de l'antiquité à nos jours (Louvain 1987), pp. 311-23.

— , 'Louis XIV et les papes aux prises avec le Jansénisme', Archivum Historicae Pontificae, 31 (1993), 109-92; 32 (1994), 65-148. 
Blondel, Paulin, Le Cardinal Du Perron, archevêque de Sens, grand aumônier de France, (1556-1618). Etude historique (Sens 1899).

Bonney, Richard, The Limits of Absolutism in Seventeenth-Century France (Aldershot and Brookfield, Vermont 1995).

Bonnot, Isabelle, Hérétique ou saint? Henri Arnauld, évêque janséniste d'Angers au xviie siècle (Paris 1983).

Boularand, E., 'Le Sacerdoce de la loi nouvelle d'après le décret du Concile de Trente sur le sacrement de l'ordre', Bulletin de Littérature Ecclésiastique (1955), 193-228.

Brémond, Henri, Histoire littéraire du sentiment religieux en France depuis la fin des guerres de religion jusqu'à nos jours, 12 vols (Paris 1916-36).

Briggs, Robin, Communities of Belief. Cultural and Social Tensions in Early Modern France (Oxford 1995).

-, Early Modern France, 1560-1715 (Oxford, 2nd edition 1998).

Broutin, Paul, La Réforme pastorale en France au xviie siècle, 2 vols (Paris and Tournai 1956).

, 'Le Concile de Bordeaux de 1624. Recherches sur la tradition pastorale en France après le Concile de Trente', Nouvelle Revue Théologique, 72 (1950), 390-409.

, 'Les Deux grands évêques de la réforme catholique', Nouvelle Revue Théologique, 75 (1953), 282-99, 380-98.

Brown, D. Catherine, Pastor and Laity in the Theology of Jean Gerson (Cambridge 1987).

Burke, Peter, The Fabrication of Louis XIV (New Haven and London 1992).

— , 'How to Become a Counter-Reformation Saint', in Kaspar von Greyerz (ed.), Religion and Society in Early Modern Europe (London 1984), pp. 45-55.

Caiger, B. J., 'Doctrine and Discipline in the Church of Jean Gerson', JEH, 41 (1990), 389-407.

Cairns, Christopher, Domenico Bollani Bishop of Brescia. Devotion to Church and State in the Republic of Venice in the Sixteenth Century (Nieuwkoop 1976).

Calvet, J., Bossuet. L'homme et l'oeuvre (Paris 1941).

Carcassonne, Ély, Fénelon. L'homme et l'oeuvre (Paris 1946).

Cargill Thompson, W. D. J., 'Sir Francis Knollys's Campaign against the Iure Divino Theory of Episcopacy', in C. Robert Cole and Michael Moody (eds), The Dissenting Tradition. Essays for Leland H. Carlson (Athens, Ohio 1975), 39-77.

Carroll, Michael, Veiled Threats. The Logic of Popular Catholicism in Italy (Baltimore and London 1996).

Ceyssens, Lucien, L'Unigenitus et sa preparation à Rome (Rome 1984).

—., 'François Hallier', Bulletin de l'Institut Historique Belge de Rome, 40 (1969), 157-264.

Châtellier, Louis, The Religion of the Poor. Rural Missions in Europe and the Formation of Modern Catholicism, c.1500-c.1800 (Cambridge 1997).

Chedozeau, Bernard, 'La Formulatiion du clergé à Alet pendant l'épiscopat de Nicolas Pavillon (1639-1677)', Chroniques de Port-Royal. Actes du colloque tenu à Alet (Paris 1982), pp. 60-78.

, 'La Faculté de Théologie de Paris au xviie siècle. Un lieu privilégié des conflits entre gallicans et ultramontains (1600-1720)', Mélanges de la Bibliothèque de la Sorbonne, 10 (1990), 39-102. 
Chesneau, Charles, Le Père Yves de Paris et son temps (1590-1678), 2 vols (Paris 1946).

Christin, Olivier, Une Révolution symbolique. L'iconoclasme huguenot et la reconstruction catholique (Paris 1991).

Chroniques de Port-Royal. Actes du colloque tenu à Alet (Paris 1982).

Church, William, Richelieu and Reason of State (Princeton 1972).

Clarke, W. K. Lowther, 'The Origins of Episcopy', in C. Jenkins and K. D. MacKenzie (eds), Episcopacy Ancient and Modern (London 1930), pp. 1-46.

Cochois, P., Bérulle et l'école française (Paris 1963).

—-, 'Bérulle, Hiérarque Dionysien', Revue d'Ascétique et de Mystique, 37 (1961), 314-53; 38 (1962), 355-75.

Cognet, A., Antoine Godeau évêque de Grasse et de Vence (Paris 1900).

Cognet, Louis, La Spiritualité française au xvii siècle (Paris 1949).

— Le Jansénisme (Paris 1964).

Congar, Yves, 'Aspects ecclésiologiques de la querelle entre mendiants et séculiers dans la seconde moitié du xiii ${ }^{\mathrm{e}}$ siècle et le début du xiv ${ }^{\mathrm{e}}$ siècle, Archives d'Histoire Doctrinale et Littéraire du Moyen Âge, 28 (1961), 35-151.

Costigan, Richard, 'Bossuet and the Consensus of the Church', Theological Studies, 56 (1995), 652-72.

Cross, Claire, 'Protestant Attitudes towards Episcopacy in the Early Modern Church', in Bernard Vogler (ed.), Miscellanea historiae pontificiae, viii (Brussels and Louvain 1987), pp. 221-8.

Dagens, Jean, Bérulle et les origines de la restauration catholique (1575-1611) (Bruges 1952).

Darricau, Raymond, Au coeur de l'histoire du Quercy. Alain de Solminihac évêque de Cahors (1593-1659) (Chambray-lès-Tours 1980).

-, 'La Correspondance de Louis d’Urfé, évêque de Limoges (1676-1696) et de M. Tronson, supérieur général de Saint-Sulpice', Le Limousin au xviie siècle. Littèrature, histoire, histoire religieuse. Colloque pluridisciplinaire Limoges, 9-10 octobre 1976 (Limoges 1979), pp. 205-19.

, 'L'Evêque dans la pensée de Saint Vincent de Paul', Divus Thomas, 84 (1981), $161-88$.

, 'L'Evêque chez les spirituels français', L'Evêque dans l'histoire de l'église (Angers 1984), pp. 109-22.

Degert, Antoine, Histoire des évêques de Dax (Paris 1903).

— , 'Saint Charles Borromée et le clergé français', Bulletin de Littérature Ecclésiastique, 4 (1912), 145-59, 193-213.

Dejean, Étienne, Un prélat indepéndant au xviie siècle. Nicolas Pavillon évêque d'Alet (1637-1677) (Paris 1909).

Delumeau, Jean, Catholicism between Luther and Voltaire, trans. Jeremy Moiser (London and Philadelphia 1977).

- Sin and Fear. The Emergence of a Western Guilt Culture 13th-18th Centuries, trans. Eric Nicholson (New York 1990).

Deroo, André, Saint Charles Borromée (Paris 1963).

Descrains, Jean, Essais sur Jean-Pierre Camus (Paris 1992).

Dewald, Jonathan, Aristocratic Experience and the Origins of Modern Culture. France 1570-1715 (Berkeley and Oxford 1993). 
Dinet, Dominique, Religion et societé. Les réguliers et la vie régionale dans les diocèses d'Auxerre, Langres et Dijon (fin Xvi-fin xviiie siècles), 2 vols (Paris 1999).

Ditchfield, Simon, Liturgy, Sanctity and History in Tridentine Italy. Pietro Maria Campi and the Preservation of the Particular (Cambridge 1995).

Doublet, Georges, La Bibliothèque d'un évêque de Grasse et de Vence à la fin du xvie siècle (Aix-en-Provence 1904).

, Godeau évêque de Grasse et de Vence (1605-1672) (Paris 1911).

Doyle, William, Jansenism (Basingstoke and London 2000).

Dubois, Georges, Henri de Pardaillan de Gondrin, archevêque de Sens (1646-1674) (Alençon 1901).

Dubruel, Marc, 'Un épisode de l'histoire de l'église de France au xvii siècle. Nicolas Pavillon, évêque d'Alet et Étienne de Caulet, évêque de Pamiers', Recherches de Science Religieuse (1917), 52-92.

, 'Hiérarchie gallicane et religieux exempts. Un épisode de leurs relations au xvii siècle. Caulet et les Jésuites', Recherches de Science Religieuse (1919), 324 68; (1920), 55-91.

Dufourg, Robert, Un prélat amiral sous Louis XIII. Henri de Sourdis (Bordeaux 1944).

Duine, François, Un politique et orateur au xviie siecle, Cohon, évêque de Nîmes et de Dol. Essai de bio-bibliographie avec documents inédits (Rennes 1902).

—, Avant Bossuet. Cohon évêque de Nîmes et de Dol. Précepteur des neveux de Mazarin. Prédicateur du roi (Paris 1908).

Dumoulin, P., 'Les Visites pastorales d'Alain de Solminihac', in Pierre Pommaréde (ed.), Alain de Solminihac (Périgueux 1993), pp. 18-29.

Du Pin, Louis Ellies, Histoire ecclésiastique du xviie siècle, 4 vols (Paris 1714).

Dupuy, Michel, Bérulle et le sacerdoce. Etude historique et doctrinale (Paris 1969).

Duval, André, Des sacrements au Concile de Trente (Paris 1985).

Evennett, Henry Outram, The Cardinal of Lorraine and the Council of Trent (Cambridge 1930).

, The Spirit of the Counter-Reformation (Cambridge 1968).

Faillon, Étienne-Michel, Vie de M. Olier fondateur du séminaire de Saint-Sulpice, 3 vols (Paris, 4th edition 1873).

Fincham, Kenneth, Prelate as Pastor. The Episcopate of James I (Oxford 1990).

Forrestal, Alison, Catholic Synods in Ireland, 1600-1690 (Dublin 1998).

—, "Fathers, Leaders, Kings". Episcopacy and Episcopal Reform in the Seventeenth-Century French School', The Seventeenth Century, 17 (2002), $24-47$.

- 'Making Bishops in Tridentine France. The Episcopal Ideal of Jean-Pierre Camus', JEH, 54 (2003), 254-77.

Foster, Andrew, 'The Function of a Bishop. The Career of Richard Neile, 1562-1640', in Felicity Heal and Rosemary O'Day (eds), Continuity and Change: Personnel and Administration of the Church of England 1500-1642 (Leicester 1976), pp. 33-54.

Fougeray du Coudrey, M., 'René Le Sauvage évêque de Lavaur 1630-1677', Extrait du Bulletin du Pays de Granville (1909), 1-35.

Fouqueray, Henri, Histoire de la compagnie de Jésus en France des origines à la suppression (1528-1762), 5 vols (Paris 1910-22). 
Fumaroli, Marc, L'Âge de l'éloquence (Geneva 1980).

Gadille, Jacques (ed.), Le Diocèse de Lyon (Paris 1983).

Gaillard, Jean, Un prélat Janséniste. Choart de Buzenval, évêque de Beauvais 1651-1679 (Paris 1902).

Gaquère, François, Pierre de Marca, sa vie, ses oeuvres, son gallicanisme (Paris 1932).

Garreau, Albert, Jean-Pierre Camus (Paris 1968).

Gazier, Augustin, Histoire générale du mouvement Janséniste depuis ses origines jusqu'à nos jours, 2 vols (Paris 1924).

Gérin, Charles, Recherches historiques sur l'assemblée du clergé de France de 1682 (Paris, 2nd edition 1870).

Golden, Richard, The Godly Rebellion. Parisian Curés and the Religious Fronde 1652-1662 (Chapel Hill, North Carolina 1981).

, 'The Mentality of Opposition. The Jansenism of the Parisian Curés during the Religious Fronde', Catholic Historical Review, 64 (1978), 565-80.

, 'Jean Rousse, Religious Frondeur', French Historical Studies, 12 (1982), 461-85.

Gouyon, Paul, L'Introduction de la réforme disciplinaire du Concile de Trente dans le diocèse de Bordeaux (1582-1624) (Bordeaux 1945).

Greengrass, Mark, 'Aristocracy and Episcopacy at the End of the Wars of Religion in France. The Duke of Montmorency and the Bishoprics of Languedoc', in Bernard Vogler (ed.), Miscellanea historiae pontificae, viii (Brussels and Louvain 1987), pp. 356-63.

Gres-Gayer, Jacques, Le Jansénisme en Sorbonne 1643-1656 (Paris 1996).

- Le Gallicanisme de Sorbonne. Chroniques de la Faculté de Théologie de Paris (1657-1688) (Paris 2002).

Guillemain, Bernard, Le Diocèse de Bordeaux (Paris 1974).

Haliczer, Stephen, Sexuality in the Confessional. A Sacrament Profaned (New York and Oxford 1986).

Hankey, Wayne, 'Dionysian Hierarchy in St. Thomas Aquinas. Tradition and Transformation', in Ysabel de Andia (ed.), Denys l'Aréopagite et sa postérité en Orient et en Occident. Actes du Colloque International Paris, 21-24 septembre 1994 (Paris 1997), pp. 405-38.

, 'Augustinian Immediacy and Dionysian Mediation in John Colet, Edmund Spenser, Richard Hooker and the Cardinal de Bérulle', in Dominique de Courcelles (ed.), Augustinus in der Neuzeit. Colloque de la Herzog August Bibliothek de Wolfenbüttel, 14-17 octobre, 1996 (Turnhout 1998), pp. 125-60.

Harline, Craig, and Eddy Put, A Bishop's Tale. Mathias Hovius among his Flock in Seventeenth-Century Flanders (New Haven and London 2000).

Hatton, Ragnhild (ed.), Louis XIV and Absolutism (London and Basingstoke 1976).

Hayden, J. Michael, France and the Estates General of 1614 (Cambridge 1973).

- 'The Social Origins of the French Episcopacy at the Beginning of the Seventeenth Century', French Historical Studies, 10 (1977), 27-38.

Hayden, J. Michael and Malcolm Greenshields, 'The Clergy of Early SeventeenthCentury France: Self-Perception and Society's Perception', French Historical Studies, 18 (1993), 145-72. 
Headley, John M. and John B. Tomaro (eds), San Carlo Borromeo. Catholic Reform and Ecclesiastical Politics in the Second Half of the Sixteenth Century (Washington 1988).

Hefele, Charles, Histoire des conciles d'après les documents originaux, 11 vols (Paris 1907-52).

Hoffman, Philip, Church and Community in the Diocese of Lyon 1500-1789 (New Haven and London 1984).

Hughes, Philip, Rome and the Counter-Reformation in England (London 1942).

Jacques, Émile, Philippe Cospeau, un ami-ennemi de Richelieu 1571-1646 (Paris 1989).

Jedin, Hubert, L'Evêque dans la tradition pastorale du xvie siècle, ed. Paul Broutin (Brussels 1953).

—, A History of the Council of Trent, trans. Ernest Graf, 2 vols (London 1957-61).

- Crisis and Closure of the Council of Trent 1562-1563 (London 1967).

Jedin, Hubert and John Dolan (eds), The Church in the Age of Absolutism and Enlightenment, vi (London 1981).

Jenkins, C. and K. D. MacKenzie (eds), Episcopacy Ancient and Modern (London 1930).

Jenny, Jean, 'Un archévêque réformateur: Pierre d'Hardivilliers, archévêque de Bourges (1639-1649)', Bulletin de la Societé d'Emulation du Bourbonnais (1971), 597-610.

Jobit, Pierre, L'Evêque des pauvres. Saint Thomas de Villeneuve (Paris 1961).

Kamen, Henry, The Phoenix and the Flame. Catalonia and the Counter-Reformation (New Haven and London 1993).

Keohane, Nannerl O., Philosophy and the State in France (Princeton 1980).

Kettering, Sharon, Patrons, Brokers and Clients in Seventeenth-Century France (New York and Oxford 1986).

Kleinman, Ruth, Saint Francis de Sales and the Protestants (Geneva 1962).

Klevgard, Paul, 'Society and Politics in Counter-Reformation France. A study of Bérulle, Vincent de Paul, Olier and Bossuet', (PhD dissertation, Northwestern University, Illinois 1971).

Knecht, Robert, The Fronde (London 1975).

Krumenacker, Yves, L'Ecole française de spiritualité (Paris 1998).

Lake, Peter, Anglicans and Puritans? Presbyteriansim and English Conformist Thought from Whitgift to Hooker (London 1988).

Le Bras, Gabriel, Etudes de sociologie religieuse, 2 vols (Paris 1955).

- L'Eglise et le village (Paris 1976).

Lécuyer, Joseph, 'Aux origines de la théologie thomiste de l'épiscopat', Gregorianum, 35 (1954), 56-89.

—_ 'Les Etapes de l'enseignement thomiste sur l'épiscopat', Revue Thomiste, 57 (1957), 29-52.

Lefebvre, Charles-Hugues, Vie de Monsieur Pavillon, évêque d'Alet, 3 vols (Utrecht, 2nd edition 1739).

Le Limousin au xvii siècle. Littèrature, histoire, histoire religieuse. Colloque pluridisciplinaire Limoges, 9-10 octobre 1976 (Limoges 1979).

Le Maistre, Joseph, Du pape, suivi de l'église gallicane dans son rapport avec le souverain pontife, 2 vols (Brussels 1852). 
La Morandiere, Fernand Potier de, Augustin Potier, évêque et comte de Beauvais, pair de France (Paris 1902).

Lemaître, Nicole, Le Rouergue flamboyant. Le clergé et les fidèles du diocèse de Rodez 1417-1563 (Paris 1988).

— - 'Le Prêtre mis à part ou le triomphe d'une idéologie sacerdotale au xvi ${ }^{\mathrm{e}}$ siècle', Revue d'Histoire de l'Eglise de France, 85 (1999), 275-89.

L'Evêque dans l'histoire de l'église (Angers 1984).

Lightfoot, J. B., The Apostolic Fathers, 2 vols (London 1885).

Logan, Oliver, The Venetian Upper Clergy in the Sixteenth and Early Seventeenth Centuries (New York and Queenston, Ontario 1996).

Lubac, Henri de, Augustinianism and Modern Theology, trans. Lancelot Sheppard (London 1969).

Luria, Keith, Territories of Grace: Cultural Change in the Seventeenth-Century Diocese of Grenoble (Berkeley and Oxford 1991).

Martimort, Aimé-Georges, Le Gallicanisme de Bossuet (Paris 1953).

Martin, Henri-Jean, Print, Power and People in Seventeenth-Century France, trans. David Gerard (New Jersey 1993).

Martin, Hervé, Le Métier du predicateur à la fin du Moyen Âge, 1350-1520 (Paris 1988).

Martin, Victor, Le Gallicanisme et la réforme catholique (Paris 1919).

- Le Gallicanisme politique et le clergé de France (Paris 1929).

- Les Origines du gallicanisme, 2 vols (Paris 1939).

Martos, Joseph, Doors to the Sacred. A Historical Introduction to Sacraments in the Catholic Church (New York 1982).

Marzac, Nicolas, The Library of a French Bishop in the Late Sixteenth Century (Paris 1974). Massaut, Jean-Pierre, Josse Clichtove, l'humanisme et la réforme du clergé, 2 vols (Paris 1968). Mazeau, Roland, La Vie de Monseigneur Alain de Solminihac abbé de Chancelade évêque de Cahors 1593-1659 (Perigiueux 1980).

McManners, John, French Ecclesiastical Society under the Ancien Régime. A Study of Angers in the Eighteenth Century (Manchester 1960).

- Church and Society in Eighteenth-Century France, 2 vols (Oxford 1998).

Mesnard, Jean, 'Un évêque de Bazas solitaire de Port-Royal: Henri Litolfi-Maroni', Revue Historique de Bordeaux et du Département de La Gironde, 10 (1961), 5-78.

—_ 'La Collaboration des écrivains de Port-Royal aux censures', Chroniques de PortRoyal. Actes du colloque tenu à Alet (Paris 1982), pp. 3-20.

Mettam, Roger, Power and Faction in Louis XIV's France (Oxford and New York 1988).

Michaud, Claude, L'Eglise et l'argent sous l'ancien régime. Les receveurs généraux du clergé de France aux $\mathrm{xvi}^{\mathrm{e}} \mathrm{-}$-xvii ${ }^{e}$ siècles (Paris 1991).

Necheles, Ruth, 'The Curés in the Estates General of 1789', Journal of Modern History, 46 (1974), 425-44.

Neveu, Bruno, Religion et érudition aux xviie et xviiie siècles (Paris 1994).

Nicholls, David, 'Inertia and Reform in the Pre-Tridentine French Church. The Response to Protestantism in the Diocese of Rouen, 1520-1562', JEH, 32 (1981), 185-97.

Nugent, Donald, Ecumenism in the Age of the Reformation. The Colloquy of Poissy (Cambridge, Massachusetts 1974). 
Oakley, Francis, 'Almain and Major: Conciliar Theory on the Eve of the Reformation', American Historical Review, 70 (1964-5), 673-90.

, 'Conciliarism in the Sixteenth Century: Jacques Almain Again', Archiv für Reformationsgeschichte, 68 (1977), 111-32.

Oechslin, R. L., Louis de Granada (London 1962).

O’Malley, John, Trent and All That. Renaming Catholicism in the Early Modern Era (Cambridge, Massachusetts and London 2000).

, 'Saint Charles Borromeo and the Praecipuum episcoporum munus. His Place in the History of Preaching', in John M. Headley and John B. Tomaro (eds), San Carlo Borromeo. Catholic Reform and Ecclesiastical Politics in the Second Half of the Sixteenth Century (Washington 1988), pp. 139-57.

Orcibal, Jean, Jean Duvergier de Hauranne. Abbé de Saint-Cyran et son temps (1581-1638) (Louvain and Paris 1947).

- Louis XIV contre Innocent XI (Paris 1949).

- La Spiritualité de Saint-Cyran avec ses écrits de piété inédits (Paris 1962).

—_, 'L'Idée d'église chez les catholiques du xvii siècle', Relazioni del x Congresso Internazionale di Scienze Storiche, Roma 4-11 septembre 1955 (Florence 1955), pp. 111-35.

Pascoe, Louis, Jean Gerson. Principles of Church Reform (Leiden 1973).

Pastor, Ludwig von, History of the Popes, 40 vols (London 1891-1953).

Pégon, J., 'Episcopat et hiérarchie au Concile de Trente', Nouvelle Revue Théologique, 82 (1960), 580-8.

Peronnet, Michel, Les Evêques de l'ancienne France, 2 vols (Lille 1978).

Peyrous, Bernard, La Réforme catholique à Bordeaux (1600-1719), 2 vols (Bordeaux 1995).

— , 'La Réforme institutionnelle de l'archidiocèse de Bordeaux au temps du cardinal François de Sourdis (1599-1628)', Revue d'Histoire Ecclésiastique, 76 (1981), 5-47.

Phillips, Henry, Church and Culture in Seventeenth-Century France (Cambridge 1997).

Pioger, André, Un orateur de l'école française. Saint Jean Eudes (1601-80) (Paris 1940).

Pister, Danielle (ed.), L'Image du prêtre dans la littérature classique (xvii - -xviii ${ }^{e}$ siècles). Actes du colloque organisé par le centre 'Michel Baude - Littérature et Spiritualité' de l'Université de Metz, 20-21 novembre 1998 (Berne 2001).

Piton, M., 'L'Idéal épiscopal selon les prédicateurs français de la fin du $\mathrm{xv}^{\mathrm{e}}$ et du début de xvi' siècle', Revue d'Histoire Ecclésiastique, 61 (1966), 77-118, 393-423.

Plongeron, Bernard, 'Charles Borromée, exemple et modèle: son influence en France (xvi -xix ${ }^{\mathrm{e}}$ siècles)', San Carlo e il suo tempo (Rome 1986), pp. 493-525.

Pouy, F., 'Histoire de François Faure, 77évêque d'Amiens 1612-87', Mémoires de la Société des Antiquaires de Picardie, 25 (1876), 137-286.

Powis, Jonathan, 'Gallican Liberties and the Politics of Later Sixteenth-Century France', Historical Journal, 26 (1983), 515-30.

Préclin, Edmon, Les Jansénistes du xviiie siècle et la constitution civile du clergé. Le développement du richérisme. Sa propagation dans le bas-clergé: 1713-1791 (Paris 1929).

Prodi, Paulo, Il cardinale Gabriele Paleotti (1522-1597), 2 vols (Rome 1959).

- The Papal Prince. One Body and Two Souls. The Papal Monarch in Early Modern Europe, trans. Susan Haskins (Cambridge 1987). 
, 'Charles Borromée, archevêque de Milan, et la papauté', Revue d'Histoire Ecclésiastique, 62 (1967), 379-411.

, 'The Application of the Tridentine Decrees. The Organisation of the Diocese of Bologna during the Episcopate of Cardinal Gabriele Paleotti', in Eric Cochrane (ed.), The Late Italian Renaissance, 1525-1630 (London 1970), pp. 226-43.

Prunel, Louis, Sébastien Zamet, évêque-duc de Langres, pair de France (1588-1655), sa vie et ses oeuvres (Paris 1912).

Puyol, Edmond, Edmond Richer. Etude historique et critique sur la rénovation du gallicanisme au commencement du xviie siècle, 2 vols (Paris 1876).

Quantin, Jean-Louis, Le Catholicisme classique et les pères de l'église. Un retour aux sources (1669-1713) (Paris 1999).

Ranum, Orest, The Fronde. A French Revolution, 1648-1652 (New York and London 1993).

Ravenez, L.-W., Histoire du cardinal François de Sourdis (Bordeaux 1867).

Ravitch, Norman, Sword and Mitre: Government and Episcopacy in France and England in the Age of Aristocracy (The Hague 1966).

Richet, Denis, 'Sociocultural Aspects of Religious Conflicts during the Second Half of the Sixteenth Century', in Robert Forster and Orest Ranum (eds), Ritual, Religion and the Sacred (Baltimore 1982), pp. 182-212.

Robert, Charles, Anthyme-Denis Cohon (Rennes 1895).

Roman, José María, St Vincent de Paul. An Autobiography, trans. Joyce Howard (London 1999).

Sabean, David, Power in the Blood. Popular Culture and Village Discourse in Early Modern Germany (Cambridge 1984).

Salmon, Renaissance and Revolt. Essays in the Intellectual and Social History of Early Modern France (Cambridge 1987).

- 'Clovis and Constantine. The Uses of History in Sixteenth-Century Gallicanism', JEH, 41 (1990), 523-605.

Sanders, E. K., Fénelon. His Friends and his Enemies 1651-1715 (London 1901).

Sauzet, Robert, Contre-réforme et réforme catholique en bas-Languedoc. Le diocèse de Nîmes au xviie siècle (Louvain and Paris 1979).

Sedgwick, Alexander, Jansenism in Seventeenth-Century France. Voices from the Wilderness (Charlottesville, Virginia 1977).

, The Travails of Conscience. The Arnauld Family and the Ancien Régime (Cambridge, Massachusetts and London 1998).

Sheppard, Lancelot, Barbe Acarie, Wife and Mystic. A Biography (London 1953).

Sheils, W. J., 'An Archbishop in the Pulpit: Tobie Matthew's Preaching Diary 1606-1622', in Diana Wood (ed.), Life and Thought in the Northern Church c. 1100-c.1700 (Suffolk 1999), pp. 381-405.

Sol, Eugène, Le Vénérable Alain de Solminihac abbé de Chancelade et évêque de Cahors (Cahors 1928).

Sommerville, J. P., 'The Royal Supremacy and Episcopacy “Jure Divino”, 1603-1640', JEH, 34 (1983), 548-58.

Stump, Phillip, The Reforms of the Council of Constance (1414-1418) (Leiden, New York and Cologne 1994). 
Sutherland, Nicola, The Huguenot Struggle for Recognition (New Haven and London 1980). , Princes, Politics and Religion 1547-1589 (London 1984).

Tackett, Timothy, Priest and Parish in Eighteenth-Century France. A Social and Political Study of the Curés in a Diocese of Dauphiné (Princeton, New Jersey 1977).

Tallon, Alain, La France et le Concile de Trente (1518-1563) (Rome 1997).

Taveneaux, Réné, Le Catholicisme dans la France classique, 1610-1715, 2 vols (Paris 1980). - Jansénisme et réforme catholique (Nancy 1992).

, 'L'Evêque selon Port-Royal', Jansénism et réforme catholique (Nancy 1992), pp. 75-87.

Taylor, Larissa, Soldiers of Christ (New York 1992).

- Heresy and Orthodoxy in Sixteenth-Century Paris. François Le Picart and the Beginnings of the Catholic Reformation (Leiden, Boston and Cologne 1999).

Terrebasse, H. de, Pierre de Villars archévêque et comte de Vienne 1545-1613 (Lyons 1897).

Tierney, Brian, Origins of Papal Infallibility 1150-1350 (Leiden 1972).

- Foundations of the Conciliar Theory. The Contribution of the Medieval Canonists from Gratian to the Great Schism (Leiden, New York and Cologne 1998).

Tillier, Jean-Claude, Les Synodes du cardinal François de Sourdis, 1602-1609 (Bordeaux 1971).

Tomaro, John B., 'San Carlo Borromeo and the Implementation of the Council of Trent', in John M. Headley and John B. Tomaro (eds), San Carlo Borromeo. Catholic Reform and Ecclesiastical Politics in the Second Half of the Sixteenth Century (Washington 1988), pp. 67-84.

Toujas, René, 'A propos de la conférence épiscopale de Mercuès (Lot) en 1649. Publication de directives inédites de pastorale', Actes du 96 Congrès National des Sociètès Savantes (Paris 1976), pp. 95-105. , 'Les Démêlés de Samuel Martineau, évêque de Bazas (1646-1667) avec le parlement de Bordeaux', Actes du 104 Congrès National des Sociétés Savantes, ii (Paris 1981), pp. 51-62.

Treasure, Geoffrey, Mazarin. The Crisis of Absolutism in France (London 1995).

Truchet, J., Le Prédication de Bossuet. Etude de thèmes, 2 vols (Paris 1960).

Tyler, J. Jeffery, Lord of the Sacred City. The Episcopus Exclusus in Late Medieval and Early Modern Germany (Leiden, Boston and Cologne 1999).

Ullmann, Walter, Medieval Political Thought (Harmondsworth 1975).

Valette, Jean, 'La Conférence de Mercuès (1649)', Annales du Midi (1957), 71-9.

—_ 'Nicolas Sevin, évêque de Sarlat (2 mai 1648 - septembre 1657)', Actes du 96 ${ }^{e}$ Congrès National des Sociétés Savantes, ii (Paris 1976), pp. 57-70.

Van Kley, Dale, The Religious Origins of the French Revolution (New Haven and London 1996).

Vansteenberghe, E., 'Un programme d'action épiscopale au début du xve siècle (lettre inédite de Jean Gerson)', Revue des Sciences Religieuses, 19 (1939), 24-38.

Van Veghel, Optatus, Benoît de Canfield (1562-1610), sa vie, sa doctrine et son influence (Rome 1949).

Veissière, Michel, 'Guillaume Briçonnet, évêque de Meaux, et la réforme de son clergé'. Revue d’Histoire Ecclésiastique, 84 (1989), 655-72. 
Venard, Marc, Réforme protestante, réforme catholique dans la province d’Avignon xvie siècle (Paris 1993).

, Le Catholicisme à l'épreuve dans la France du xvie siècle (Paris 2000).

, 'Une réforme gallicane? Le projet de concile national de 1551', Revue d'Histoire de l'Église de France, 68 (1981), 201-25.

, 'The Influence of Carlo Borromeo on the Church of France', in John M. Headley and John B. Tomaro (eds), San Carlo Borromeo. Catholic Reform and Ecclesiastical Politics in the Second Half of the Sixteenth Century (Washington 1988), pp. 208-27.

-, 'Henri IV et la réforme catholique', Henri IV le roi et la reconstruction du royaume. Actes du $3^{e}$ Colloque Pau-Nérac, $14-17$ septembre 1989 (Pau 1990), pp. 301-15.

— , 'Ultramontane or Gallican? The French Episcopate at the End of the Sixteenth Century', The Jurist, 52 (1992), 142-61.

— torique (1992), 625-44.

Vidal, Jean-Marie, Henri de Sponde, recteur de Saint-Louis des Français, évêque de Pamiers (1568-1643) (Rome 1929).

—, François-Étienne de Caulet évêque de Pamiers (1610-1680) (Paris 1939).

Viguerie, Jean de, 'Les Evêques d'Angers et la réforme catholique (1540-1758)', L'Evêque dans l'histoire de l'église (Angers 1984), pp. 91-108.

Vogler, Bernard (ed.), Miscellanea historiae pontificiae, viii (Brussels and Louvain 1987).

Walker Bynum, Caroline, Holy Feast and Holy Fast. The Religious Significance of Food to Medieval Women (Berkeley, Los Angeles and London 1987).

Walsh, Eugene, 'The Priesthood in the Writings of the French School: Bérulle, De Condren, Olier' (PhD dissertation, Catholic University of America, Washington DC 1949).

Wanegffelen, Thierry, Une difficile fidélité. Catholiques malgré le concile en France $\mathrm{xvi}^{-}{ }^{-} \mathrm{xvii^{e }}$ siècles (Paris 1999).

Welter, Louise, La Réforme ecclésiastique du diocèse de Clermont au xviie siècle (Paris 1956).

Whitmore, P., The Order of Minims in Seventeenth-Century France (The Hague 1967).

Williams, Charles, The French Oratorians and Absolutism, 1611-1641 (New York 1989).

Worchester, Thomas, Seventeenth-Century Cultural Discourse. France and the Preaching of Bishop Camus (Berlin 1997).

Wright, Anthony, The Counter-Reformation: Catholic Europe and the Non-Christian World (London 1982).

, Catholicism and Spanish Society under the Reign of Philip II, 1555-1598, and Philip III, 1598-1621 (Lewiston, Queenston, Ontario and Lampeter 1991).

, The Early Modern Papacy. From the Council of Trent to the French Revolution 1564-1789 (Harlow 2000).

, 'San Juan de Ribera and Saint Charles Borromeo. The Counter-Reformation in Spain and Italy Compared', in Bernard Vogler (ed.), Miscellanea historiae pontificiae, viii (Brussels and Louvain 1987), pp. 364-72.

, 'The Borromean Ideal and the Spanish Church', in John M. Headley and John

B. Tomaro (eds), San Carlo Borromeo. Catholic Reform and Ecclesiastical Politics in the Second Half of the Sixteenth Century (Washington 1988), pp. 188-208. 


\section{Index}

Note: 'n.' after a page reference indicates the number of a note on that page.

Abelly, Louis 68, 195

Acarie, Barbe 51-2, 216

administration, episcopal 6-13, 23-4, 33-44, 118, 154, 183-97, 201, 202-4, 220-1, 226

Agen, bishops of 22

see also Delbène, Barthélemy; Joly, Claude; Villars, Nicolas de

Aire, bishop of 153 see also Cospeau, Philippe

Aix, archdiocese of 170n.98 see also Cosnac, Daniel de; Grimaldi, Jerome de; Richelieu, Alphonse

Alberigo, Giuseppe 33, 35

Albi, diocese of see Delbène, Alphonse

Alet, bishop of 165 see also Pavillon, Nicolas

Alexander VII 116, 126

Alexander VIII 159

Amiens, diocese of 104n.45 see also Faure, François

Angers, diocese of 96, 97-100 see also Arnauld, Henri; Fouquet de la Varenne, Guillaume

Angoulême, diocese of see La Rochefoucauld, Antoine de

Apostles 68, 81, 135, 153-4, 156, 181, 183, 187, 194, 199

see also hierarchy; jurisdiction; priesthood; Trent, Council of

Arles, diocese of see Barrault, Jean Jaubert de Arnauld, Antoine 130, 137, 140n.73, 209n.114

see also Jansenism

Arnauld, Henri 96, 99, 126, 128, 129, 136, $145,189,206$ n.25

Assembly of Clergy 12, 38, 60, 77, 101-2,
122-37 passim, 146-8, 165-6, 178, 183, 218-25 passim

debates of $20,22,83,85,116-19,155-6$, 161

decisions of 31, 83-6, 100-35 passim, 139n.61, 150-63 passim, 167n.21, 179, 184, 200, 202, 224 see also Déclaration sur les réguliers

Auch, archdiocese of see Destrappes,

Léonard

Austria, Anne of 59, 66, 67, 188, 226

Autun, bishop of 150

Auvry, Claude, bishop of Bayeux 58-9

Auxerre, bishop of 86

see also Broc, Pierre de; Colbert, Nicolas

Avignon 37

Bagot, Jean 82, 87, 100, 116, 119

Barcos, Martin de 143n.123

see also Jansenism

Barrault, Jean Jaubert de, bishop of Bazas and Arles 145, 185

Bascapé, Carlo 42

Bayeux, diocese of see Auvry, Claude; Daillon du Lude, René

Bayonne, diocese of see Abelly, Louis;

Deschaux, Bertrand; Fouquet, François

Bazas, bishop of 165

see also Barrault, Jean Jaubert de

B. d'Hérédie see Vernant, Jacques de

Beaune, Renaud de, archbishop of Bourges 21, 23, $45 \mathrm{n} .4$

Beauvais, diocese of see Choart de Buzenval, Nicolas; Potier, Augustin

Bellegarde, Octave de St Lary de, bishop of Comminges and archbishop of Sens

174 
Belley, diocese of see Camus, Jean-Pierre Benoist, René, bishop elect of Troyes 22 Bergin, Joseph 5, 145

Bertier, Pierre de, bishop of Montauban 118, 119

Bérulle, Pierre de 3, 10, 11, 51-69 passim, 81, 93, 99, 121, 174-87 passim, 195, 210n.145, 216-17

Béthune, Henri de, bishop of Maillezais and archbishop of Bordeaux 146

Binet, Étienne 103n.27, 174, 196

Bologna, Concordat of 5, 21, 145, 226

see also monarchy, French

Bonaventure de Sainte-Anne see Vernant, Jacques de

Bonichon, François 96-7, 99, 100

Bordeaux, archdiocese of see Béthune, Henri de; parlement, of Bordeaux; Sourdis, François de; Sourdis, Henri de

Bordeaux, council of 112-13, 114, 124, 152, 162, 164, 192

Borromeo, Charles 2-4, 9-10, 13, 35-44 passim, 112, 170n.109, 171, 176-8, 180-99 passim, 204, 220

Borromeo, Federico 9, 37-8, 192, 193

Bosquet, François, bishop of Lodève and Montpellier 65, 145, 203

Bossuet, Jacques-Benigne, bishop of Meaux 111, 114, 131-5 passim, 148, 162, 196-8, 200, 221, 227

Bourges 38

archbishops of 140n.71

see also Beaune, Renaud de; Frémiot, André;

Hardivilliers, Pierre d'

Bourges, Pragmatic Sanction of 21

Bourgoing, François 51

Bourlon, Mathieu, bishop of Soissons 135, 153

Boutault, Gilles, bishop of Aire and Evreux 170n.118

Brandon, Philibert de, bishop of Périgueux 67, 68, 175, 203

Briçonnet, Guillaume, bishop of Meaux 23

Briggs, Robin 161

Broc, Pierre de, bishop of Auxerre 125

Broutin, Paul 3-4

Cahors, diocese of see Sévin, Nicolas; Solminihac, Alain de
Cambrai, diocese of see Fénelon, François de Salignac de La Mothe-

Camus, Jean-Pierre, bishop of Belley 14, 38, $65,99,110-21$ passim, $135,150-5$ passim, 174-88 passim, 190-9 passim, 210-21 passim

Canterbury, Thomas of see Saint Thomas à Beckett

Catholic League 31-2, 51-2

Caulet, François-Étienne, bishop of Pamiers 62-8, 72n.58, 126, 128, 158-65 passim, $175,186,195,200-20$ passim

Caussin, Nicolas 194, 195, 199

Cavet, Étienne 191, 193, 210n.153

Cellot, Louis $84-5$

Châlons-sur-Marne, bishop of 133 see also Vialart, Felix

charity $13,62,94,177,185-7,194-8$, 201-4, 220-1, 223

Chartres, diocese of 104n.45 see also Etampes de Valençay, Leonor d'

Chassebras, Jean-Baptiste 138n.22

Chastenet, Leonard 202

chastity 193

Choart de Buzenval, Nicolas de, bishop of Beauvais 108n.139, 126, 128, 140n.77, 186, 192

Choiseul, Gilbert de, bishop of Comminges 130, 133, 142n.104, 162

Clement IX 126, 129, 140n.79

Clichtove, Josse 25, 29

Cohon, Anthime-Denis, bishop of Nîmes and Dol 119, 200-1, 220

Colbert, Jacques-Nicolas, archbishop of Rouen 201

Colbert, Nicolas, bishop of Luçon and Auxerre 145

Comminges, bishop of 165 see also Donadieu de Griet, Barthélemy de; Choiseul, Gilbert de; Labatut, Hugues

communion see eucharist

Condren, Charles de 10, 51-66 passim, 71n. 39, 93, 175, 190, 216

conférences des mardis 68 see also Mission, Congregation of the confession, sacrament of 42, 79-87 passim, 96-7, 100, 101, 113, 175, 177, 179

confirmation, sacrament of $28,56,91-2$ congregations forane $38,191,192$ 


\section{Conserans}

bishop of 165

diocese of 212n.196

see also Marca, Pierre de; Marmiesse,

Bernard de

Constance, Council of 29-30, 131, 162

contemplation 40, 190

see also meditation

Cosnac, Daniel de, bishop of Valence and Aix 163

Cospeau, Philippe, bishop of Aire, Nantes and Lisieux 65, 67, 153, 155, 161, 185, 202, 207n.63

councils, provincial see synods, provincial

courage 42, 181

crown, French see monarchy, French

curés 11-12, 55, 75-86 passim, 94-102, 110, 115, 149-57 passim, 192, 216-17, 222, 225

see also congregations forane; gallicanism; jurisdiction

Daillon du Lude, René, bishop of Bayeux 22

David, Michel François 97

Dax, diocese of see Desclaux, Jacques

Déclaration sur les réguliers 83-5, 87, 108n.146, $112,113,114,124,178$

Delbène, Alphonse, bishop of Albi 122, 124, 132

Delbène, Alphonse III, archbishop of Orléans 124, 140n.77

Delbène, Barthélemy, bishop of Agen 124

Deschaux, Bertrand, bishop of Bayonne and archbishop of Tours 168n.35

Desclaux, Jacques, bishop of Dax 77

Despruets, Bernard, bishop of St-Papoul 57, 66

Destrappes, Léonard, archbishop of Auch 112 diligence 41

Dol, bishop of 140n. 71 see also Cohon, Anthime-Denis

Donadieu de Griet, Barthélemy de, bishop of Comminges 14, 66, 68, 172, 195, 202, 207n.63

Donnaud, Pierre de, bishop of Mirepoix 39

Dony d'Attichy, Louis, bishop of Riez and Autun 154, 155-6, 162

Du Perron, Jacques Davy, bishop of Evreux and archbishop of Sens 22, 150, 161
Du Perron, Jean Davy, archbishop of Sens 82

Dupuy, Pierre 145

Duvergier de Hauranne, Jean see Saint-Cyran

eloquence see preaching

Embrun, council of 38

Estates General (1614) 162

Estrades, Jean d', bishop of Condom 188

Etampes de Valençay, Leonor d', bishop of Chartres and archbishop of Reims 83, $145,148,174-8$ passim

eucharist

celebration of 40, 42, 54, 60, 63, 79-97 passim, 113, 175, 184, 190

devotion to 176,192

Eudes, Jean 57-9, 61-2, 66, 93, 174, 226, 227

Evreux, diocese of see Du Perron, Jacques Davy; Maupas Du Tour, Henri Cauchon de

fatherhood, episcopal 33-4, 42-3, 61-2, 174, 219

Faure, François, bishop of Glandèves and Amiens 7, 163

Fay-Peyraud, Paul-Antoine, bishop of Uzès 139n.47

Fénelon, François de Salignac de La Mothe-, bishop of Cambrai 59-60, 86, 186, 201, 227

Fenouillet, Pierre, bishop of Montpellier 203

Fisher, John 211n.164

Fleyres, Pierre de, bishop of Saint-Pons 139n.47

Floyd, John 88-94 passim

fortitude 41

Fouquet, François, bishop of Bayonne and Agde, archbishop of Narbonne 68, 197, 203

Fouquet de la Varenne, Guillaume, bishop of Angers 186

Fourth Lateran Council 79, 97

Frémiot, André, archbishop of Bourges 150

Fronde 64, 94, 96, 146, 163

Fulcran of Lodève 207n.63

gallicanism 8

and conciliarism 12, 29-30, 131-3, 135, $162,218,222,225$ 
ecclesiastical and episcopal 12, 29-36 passim, 111, 122, 123, 130-5, 145, 149-50, 162, 166, 225-6

Gallican Articles 8, 12, 131-2, 148, 158, $161-2,219,225-6$

papal infallibility 12, 82, 111, 130, 132, 133, 222-3

papal primacy $29,111,135,222-3$

political 111, 144-5, 149-50, 154, 158, 162,166

régale 8, 134, 158-62, 225-6

see also Constance, Council of; Gerson, Jean; jurisdiction; Louis XIV; monarchy, French; papacy

Gassion, Pierre, bishop of Lescar 85

Gault, Jean-Baptiste, bishop of Marseille 177, 202, 207n.63

Gerson, Jean 95, 97

and reform of episcopate 25, 43

and conciliarism 29-30

Godeau, Antoine, bishop of Grasse and Vence $68,75,85,110,129-35$ passim, 142n.110, 149-61 passim, 176-86 passim, 189-204 passim, 211n.164, 216, 220

Gondi, Jean-François de, archbishop of Paris 115

Gondi de Retz, Jean-François-Paul de, archbishop of Paris 22, 96, 115-16, 118 , 132, 149, 225

Gondrin, Henri de, archbishop of Sens 85, 108n.139, 119, 122-3, 125, 133, 142n.104, 150

government see jurisdiction

Grasse, diocese of see Godeau, Antoine

Gregory XIII 112

Grenade, Louis de 40, 41

Grenoble, diocese of see Le Camus, Étienne; Scarron, Pierre

Grimaldi, Jerome de, archbishop of Aix 159, 203

Guise see Lorraine, Charles de

Hallier, François 90-4, 115, 152, 176, 217

Hardivilliers, Pierre d', archbishop of Bourges 164, 200, 201

Harlay de Champvallon, François de, archbishop of Rouen 58, 85-7, 94-5, $115,150,152,161,163,165$
Harlay de Champvallon, François II de, archbishop of Rouen and Paris 7, 226-7

Henri IV 6, 21-2, 77, 226

hierarchy 9-12, 26, 28, 50-69 passim, 74-102 passim, 109-10, 118, 121-2, 132-6, 174, 176, 219-28 passim

holiness see piety

honesty see integrity

Hovius, Mathias 138n.8

Huguenots see protestantism

humility 34, 42, 62, 184 5, 190, 192, 193, $196,203,204$

Innocent X 124, 125, 126

Innocent XI 158, 159

Innocent XII 159

integrity 42, 62

Jansen, Cornelius 90, 125, 126

Jansenism 3, 8, 123, 131, 137, 156, 218-19, $225,226,227$

Formulary 126, 127, 128, 129, 140n.73, $151,156,182,217,219$

Jansenist bishops 12, 62, 63, 67, 68, 122-37, 140n.79, 180, 186, 219

Paix de l'église 126, 179

Port-Royal 128

Unigenitus 131, 161

Jesus and Mary, Congregation of 58

Jesus Christ 34, 118

as model for bishops 40, 42-3, $54-66$ passim, 93, 153-5, 176-201 passim

Joly, Claude, bishop of Agen 101, 119-20

Joyeuse, François de, archbishop of Narbonne, Toulouse and Rouen 10, 20, 36, 37, 39

judge, episcopal 6, 12, 30, 86, 91, 110-16 passim, 121-33 passim, 136, 149, 156-61, 218-24

jurisdiction 180-2

curial (curés') 94-101, 102, 110, 222, 223, 224

episcopal 8-13 passim, 26-30, 55-69 passim, 78-102 passim, 110-37 passim, 147-66 passim, 175, 178-82, 216-17, 221-5, 228

papal 12-13, 26, 28-30, 80-91 passim, 99, 109-35 passim, 150, 157, 162, 179, 218-25 passim 
royal $12-13,144-66,225-6$

see also gallicanism; hierarchy; Trent,

Council of

Kellison, Matthew 91

kingship, episcopal 64-5

Knott, Edward 88-94 passim

knowledge see wisdom

La Barde, Denis de, bishop of St-Brieuc 145

Labatut, Hugues, bishop of Comminges 66

La Chambre, Claude de 180-1

La Fayette, François de Motier de, bishop of Limoges 116

laity 15-16, 21-2, 81-2, 117

see also nobility, French

La Mothe-Houdancourt, Daniel de, bishop of Mende 57

Langres, diocese of 104n.45 see also Zamet, Sébastien

La Rochefoucauld, Antoine de, bishop of Angoulême 164

La Rochefoucauld, François de, bishop of Clermont and Senlis 37-8, 121-2, 150, 154-5, 161, 174, 191, 202, 207n.63

La Rochelle, diocese of 227

Lascaris d'Urfé, Louis de, bishop of Limoges 59, 198, 220

Laubespine, Gabriel, archbishop of Orléans 124

La Valette, Louis de, archbishop of Toulouse 122

Lavaur, bishop of 140n.71 see also Le Sauvage, René

learning see wisdom

Le Camus, Étienne, bishop of Grenoble 3, 159, 160, 186, 203, 204

Le Gouverneur, Guillaume, bishop of SaintMalo 181, 191

Le Maistre, Nicolas 90-3, 115, 176, 217

Le Maistre de Sacy, Isaac 177, 181, 196

Lemarie, Jean 181, 191

Le Noir, Jean 199

Le Picart, François 25

Le Prestre, Guillaume, bishop of Quimper 83, 115

Le Puy, diocese of see Maupas Du Tour, Henri Cauchon de

Le Sauvage, René, bishop of Lavaur 186
Lescalopier, Nicolas 174

Lescar, diocese of see Gassion, Pierre

Le Tellier, Charles-Maurice, archbishop of Reims 120, 145, 159, 160

Ligny, Dominique de, bishop of Meaux 142n.104

Limoges, bishop of 70n.17 see also La Fayette, François de Motier de; Lascaris, d'Urfé, Louis de

Lingendes, Jean de, bishop of Sarlat and Mâcon 188

Lionne, Hugues de 140n.75

Lisieux, bishop of 86 see also Cospeau, Philippe de

living habits, episcopal 34, 42, 62, 186, 193-5, 198, 199, 200-1 , 203, 220-1

Lodève, bishop of 140n.71 see also Bosquet, François; Plantavit, Jean

Logan, Oliver 33

Lombez, bishop of 140n.71

Lorraine, Charles de 19, 27, 30-1, 48n.78, 162,179

Louis XIII 201, 226

Louis XIV 8, 64, 120, 129, 130, 146, 151-61 passim, 201, 212n.201, 226

Louytre, Étienne 121-4 passim, 135

Luçon, diocese of see Colbert, Nicolas

Lyon, archdiocese of see Richelieu, Alphonse

Lyons, Council of 158

Malier du Houssay, Claude, bishop of Tarbes 145

Marca, Pierre de, bishop of Conserans, archbishop of Toulouse and Paris 119, 130, 133, 141n.90, 145-6, 155, 200

Marmiesse, Bernard de, bishop of Conserans 200, 202

Marseilles, diocese of 104n.45 see also Gault, Jean-Baptiste martyrdom 181, 186-7, 195-6

Martyrs, Barthélemy des 2, 9, 35-44 passim, 177-89 passim, 199

and Stimulus pastorum 40, 42

mass see eucharist

Maubourg, Claude 185

Maupas Du Tour, Henri Cauchon de, bishop of Le Puy and Evreux 191, 209n. 128

Mazarin, Jules 67, 115-16, 119, 124, 125, 145, 157, 200, 225 
Mazure, Nicolas 96, 100, 116, 119

Meaux, bishop of 133

see also Bossuet, Jacques Benigne; Briçonnet, Guillaume; Ligny, Dominique de;

Séguier, Dominique

Medici, Marie de 124, 210n.145

meditation 40, 68, 190

see also contemplation

Mende, diocese of 140n.71

see also La Mothe-Houdancourt, Daniel de

Mercuès, conferences of 175-6, 185, 190, 191, 203

Merlin, Jacques 25

Mirepoix, diocese of see Donnaud, Pierre de Mission, Congregation of the 65, 67

moderation 184

modesty 34,201

Molinier, Étienne 172

monarchy, French 1-13 passim, 21, 30, 45n.27, 64-7 passim, 88, 101-2, 126, 134, 156-60, 200, 222-8 passim

and attitude towards episcopate 144, 145, $146,147,157-9,163,218,225-7$

Conseil de Conscience 67, 226

Conseil d'État 95

Conseil du Roi 101, 154

and links to episcopate 145, 146, 161

and pope 145

see also Austria, Anne of; Fronde;

gallicanism; Henri IV; jurisdiction, royal; Lionne, Hugues de; Louis XIII;

Louis XIV; Mazarin, Jules; Medici,

Marie de; Richelieu, Armand-Jean du

Plessis de

Monluc, Jean de 20

Montauban, diocese of see Bertier, Pierre de

Montchal, Charles de, archbishop of Toulouse 114, 123, 136, 139n. 57, 150

Morel, Claude 183

Morestel, Pierre 94-5, 98, 99

mortification

exterior 193-4, 195, 197-8

interior 13, 194-8, 204

see also sacrifice; servitude

Narbonne, council of 170n.98

Netz, Nicolas de, archbishop of Orléans 85, 87

Nîmes, diocese of see Cohon, Anthime-Denis; Valernod, Pierre nobility, French 3, 5, 6, 19-20, 22, 71n.50, 145, 193

Noulleau, Jean-Baptiste 173, 174, 178-80, 181,216

Olier, Jean-Jacques 3, 57-69, 81, 93, 101, 121, 174-7, 191-5 passim, 216-27 passim

Oratory, Congregation of the $51,52,55-6$ ordination, sacrament of $28,54,56,81,92$, 94, 97, 175, 221

see also priesthood

Orléans

archbishops of 209n.114

archdiocese of 104n.45

see also Delbène, Alphonse III; Laubespine, Gabriel; Netz, Nicolas de

Pacifique à messieurs les evesques et curez, Le $80-3$

Paleotti, Gabriele 2, 35, 193

Pamiers, bishop of 165

see also Caulet, François-Étienne; Sponde,

Henri de

papacy $121,122,228$

attitude towards episcopate 11-12, 30-1,

37, 84 6, 105n. 74, 109-33 passim, 159,

$218,222,224-5$

episcopate's attitude towards 11-12,

26-32, 36, 85, 109-37, 150-64 passim,

218, 222-5

nuncios in France 31, 37, 38, 113, 114,

$119,125,133-4$

see also jurisdiction

Paris, archdiocese of 96-7, 100, 104n.45 see also Gondi, Jean-François de; Gondi de

Retz, Jean-François-Paul de; Harlay de

Champvallon, François de; Harlay de

Champvallon, François II de; Marca,

Pierre de; parlement, of Paris

Paris Faculty 76, 83

parish clergy see curés

parlement 101, 133, 151, 156, 157, 166, 226

and appels comme d'abus 108n.150, 151-3,

157, 222, 224

of Bordeaux 152

Chambre des Grands Jours d'Auvergne 156-7

of Guyenne 146

of Paris 148, 150, 156 
of Rouen 94-5, 152, 163, 165

of Toulouse 153

pastorate, episcopal 2-13 passim, 33-44 passim, 61-9 passim, 118, 128-30, 136-7, 153-7, 177-204 passim, 220-1, 223, 227

Paul, Vincent de 3, 51, 65-9, 91, 164, 175, 188-202 passim, 216, 223, 226

Pavillon, Nicolas, bishop of Alet 67, 68, 126-9, 136, 137, 139n.61, 142n.110, 158-65 passim, 175-207n.63 passim, 220 penitence 185, 193, 194, 195, 198, 203 Pepin, Guillaume 25

Périgueux, diocese of see Brandon, Philibert de; Estrades, Jean d'; Villers la Faye, Cyrus

Péronnet, Michel 4-5

Perrochel, François, bishop of Boulogne 67, 68 piety $41,62,66,68,93,94,98,184,187$, $188,189,203$

Pirot, Georges 96, 99, 165

Pius IV 30

Plantavit, Jean, bishop of Lodève 139n.47

Poissy, Colloquy of 24, 30-1

Poissy, Contract of 18 n.36

Poitiers, diocese of 104n.45, 227

politique bishops 4, 7, 25, 145, 155, 198, 199, 200-1

Potier, Augustin, bishop of Beauvais 67, 68, 90

poverty 203

material 177, 196, 198, 200, 203

spiritual 195, 198, 200, 203, 220

prayer, episcopal 35, 40, 41, 43, 68, 94, 98, 184-203 passim

preaching

episcopal 2, 6, 34 -66assim, 84, 94, 100, 177-96 passim, 221

regular 81-7 passim, 97, 101

see also pastorate, episcopal

priesthood 10-11, 28, 52-6, 58, 60-4, 67, 68,93

see also congregations forane; ordination, sacrament of

privileges 123,181

capitular 32, 76-7

episcopal 13, 111,123, 132, 136, 218, 223, 224,228

regular 12, 32, 75-120 passim, 127, 179, 216 protestantism 2, 5, 16n.2, 19-36 passim, 73n.80, 144, 164, 172, 215, 217

prudence 41, 98, 177, 192, 195

Pseudo-Dionysius 52-8 passim

Quietism 3, 201

Quimper, diocese of 104n.45 see also Le Prestre, Guillaume

Rebé, Claude de 116, 165

Reims, archdiocese of see Etampes de Valençay, Leonor d'; Le Tellier, Charles-Maurice

religious orders 216-17

Augustinians 105n.80, 108n.147

Benedictines 88

Capuchins 105n.80, 108n.147, 117

Carmelites 75, 82, 85, 105n.80, 108n.147, 121

Cordeliers 103n.16, 105n.80

Dominicans 75, 85

episcopate and 8, 11-12, 74-94 passim, 101-2, 109-10, 127-57 passim, 178, $195,218,222,224$

Franciscans 75

Jacobins 105 n. 80

Minims 75, 85, 105n.80, 108n.147

and pastoral activities 75, 79-80, 84, 85, 93, 96

Recollects 85, 103n.16

and Richard Smith conflict 87-94, 102, 217

Society of Jesus (Jesuits) 75, 78, 82-6 passim, 88-94 passim, 96, 108n.147, 174, 177-8

renunciation see sacrifice; servitude residence, episcopal 23-7, 34, 36, 38, 118, 179, 188-9

prevalence of 39, 180, 188, 191, 199, 201

Revolution, French 5, 224, 227

Ribera, Jean 35, 41

Richelieu, Alphonse, archbishop of Aix and Lyon 145, 201, 220

Richelieu, Armand-Jean du Plessis de 7, 66, $67,85,88,90,142 \mathrm{n} .107,145$, 170n.115, 226

Richer, Edmund 55, 75, 95-6, 98

Richerism 75, 225 
Rieux de Sourdéac, René de, bishop of Saint-

Pol-de-Léon 121-4, 132, 135, 136

Rose, Guillaume, bishop of Senlis and

Clermont 37

Rouen, archdiocese of 96, 97

see also Colbert, Jacques-Nicolas; David,

Michel François; Harlay de Champvallon,

François II de; Joyeuse, François de;

Morestel, Pierre; parlement, of Rouen

Rousse, Jean 108n.142

Rouvroy, Louis de see Saint-Simon, duc de

sacrifice 54, 60, 64, 176, 181, 186, $194-8$, 202, 221, 223

see also martyrdom; mortification;

servitude

Saint Ambrose 25, 43, 181, 183, 188, 190, 194

Saint Augustine 42, 52, 128, 154, 178-94 passim, 207n.63

Saint-Brieuc, diocese of see La Barde, Denis de; Villazel, Étienne de

Saint Cyprian 135, 136

Saint-Cyran 90-4, 115, 121, 175, 176, 217

Saintes, diocese of 57

Saint Gregory the Great 34, 43, 61, 183, 187, 196

Saint Ignatius of Antioch 34

Saint Jerome 97

Saint John of Chrysostom 42, 183

Saint-Malo, bishop of 140n.71

see also Le Gouverneur, Guillaume

Saint Martin, Simplician 190

Saint Martin of Tours 194, 196

Saint Paul 34, 43, 61, 68, 154, 183, 187, 199, 211 n. 164

Saint Peter 29, 81, 111, 135, 196

Saint-Pol-de-Léon, diocese of see Rieux de Sourdéac, René de

Saint-Pons, diocese of see Fleyres, Pierre de

Saint Savinian 195-6, 207n.63

Saint-Simon, duc de 212n.202

Saint Thomas à Beckett 155-6, 181, 183

Saint Thomas Aquinas 28, 63, 97

Saint Timothy see Saint Paul

Sales, François de 13, 37-8, 118, 177-86 passim, 188-204 passim

Salignac de la Mothe-Fénélon, François II de, bishop of Sarlat 202 sanctification 54-7, 69, 92-3, 175, 194, 195

see also piety

Sanguin, Nicolas, bishop of Senlis 155, 203

Sardica, Council of 123, 126, 149, 150

Sarlat, diocese of see Lingendes, Jean de; Salignac de la Mothe-Fénélon, François II de; Sévin, Nicolas

Scarron, Pierre, bishop of Grenoble 3

Séguier, Dominique, bishop of Meaux 116

seminaries 50-69 passim, 154, 191, 203

Senlis, diocese of see La Rochefoucauld,

François de; Rose, Guillaume; Sanguin, Nicolas

Sens

archbishop of 86, 108n.139

archdiocese of 76, 170n.98

see also Bellegarde, Octave de; Du Perron,

Jacques Davy; Du Perron, Jean Davy;

Gondrin, Henri de

servitude 54, 57, 60, 185, 193

see also mortification; sacrifice

Sévin, Nicolas, bishop of Sarlat and Cahors 67, 175, 188, 191, 202

Smith, Richard 87, 88, 217

Soissons, diocese of 140n.71 see also Bourlon, Mathieu

Solminihac, Alain de, bishop of Cahors 67-8, 76, 117, 129, 135, 153-64 passim, 175, 185-207n.63 passim, 220

Sorbonne 8, 76, 89

Sourdis, François d'Escoubleau de, archbishop of Bordeaux 7, 22, 38, 76-7, 112-13, 153, 162-3, 164, 165, 192

Sourdis, Henri d'Escoubleau de, archbishop of Bordeaux 7, 22, 84, 115, 152, 153

spirituality, episcopal 10, 13, 33-5, 40-4, 188-204 passim, 216, 220-1, 227

Sponde, Henri de, bishop of Pamiers 117, 164, 186

state, French see monarchy, French; parlement strength 61, 62, 66, 184, 185

study, episcopal 40, 42, 43, 68, 94, 98, 184, 189, 198

see also wisdom

Sulpician Congregation 59, 60, 65

synods

diocesan 25, 36, 38-9, 76, 95, 165, 188, $189,191,192,201$ 
provincial $37-8,41-2,112,156,162-6$, 192

see also Trent, Council of

Talon, Denis 156-7

Talon, Nicolas 177-8, 181

Tarragona, archdiocese of 163

theology of episcopacy 11, 13, 26, 33, 40-4, 53-69 passim, 109-10, 121-35 passim, $155,161,174-6,186-8,200,216-20$

Toulouse

archbishop of $140 \mathrm{n} .71$

archdiocese of 212n. 196

see also Joyeuse, François de; La Valette,

Louis de; Marca, Pierre de; Montchal, Charles de; parlement, of Toulouse

Trent, Council of 1-2, 9-12, 19-20, 130, 182,189

debates of 26-8, 30, 78, 179

decrees of 23-4, 26-8, 33-5, 61, 78, 79, $80,156,209$ n. 120

French participation at 24, 26-7, 29-31

interpretation in France 31-44 passim, 63,

77-84 passim, 96-7, 100-1, 112-23

passim, 150-1, 162-6, 179-91 passim, 216, 221-2

interpretation outside France 35-6, 112, 163

Tronson, Louis 51, 59, 70n.17, 198, 216

Troyes, diocese of see Benoist, René

ultramontanism 31, 36, 117

Urban VIII 85, 184

Uzès, diocese of see Fay-Peyraud, Paul-Antoine

Valernod, Pierre, bishop of Nîmes 77

Valier, Agostino, 9, 10, 35, 40-3 passim, 193

Vence, diocese of see Godeau, Antoine
Vernant, Jacques de 82

Vialart, Felix, bishop of Châlons-sur-Marne $68,128,142 \mathrm{n} .104,202-3$

vicar, episcopal 6

Vienne, archdiocese of see Villars, Henri de; Villars, Jérome de; Villars, Pierre de

Villars

bishops in family 22

Henri de, archbishop of Vienne 22

Jérome de, archbishop of Vienne 138n.10, 150

Nicolas de, bishop of Agen 32

Pierre III de, archbishop of Vienne 22, 31-2, 37-9

Villazel, Étienne de, bishop of Saint-Brieuc 14, 173, 178-9, 180, 181, 202, 207n.63

Villeneuve, Thomas de 181, 185, 188-9, 190, 199

Villers la Faye, Cyrus, bishop of Périgueux 188 virtue, episcopal 2, 9, 35, 40, 62-8 passim, 93, 98, 173-204 passim, 221, 226

see also charity; courage; diligence;

fortitude; humility; moderation;

modesty; mortification; piety; prudence;

wisdom; zeal

visitations, episcopal 25, 35, 38-9, 188, 191, 192, 201, 216

see also Trent, Council of

Viviers, bishop of 66

vocation of episcopate 43, 94, 137, 175, $183-4,185,190$

wisdom 41, 42, 61, 62, 66, 175-92 passim, 218,219

Zamet, Sébastien, bishop of Langres 65-6, 71n.39, 103n.27, 190

zeal $34,62,177,181,185-8,189$ 